\title{
Biomarkers in asthmatic inflammation : a study of pharmacological immunomodulation, in vitro and in vivo
}

Citation for published version (APA):

Pennings, H. J. (1999). Biomarkers in asthmatic inflammation : a study of pharmacological immunomodulation, in vitro and in vivo. [Doctoral Thesis, Maastricht University]. Universitaire Pers Maastricht. https://doi.org/10.26481/dis.19990212hp

Document status and date:

Published: 01/01/1999

DOI:

10.26481/dis.19990212hp

Document Version:

Publisher's PDF, also known as Version of record

\section{Please check the document version of this publication:}

- A submitted manuscript is the version of the article upon submission and before peer-review. There can be important differences between the submitted version and the official published version of record. People interested in the research are advised to contact the author for the final version of the publication, or visit the DOI to the publisher's website.

- The final author version and the galley proof are versions of the publication after peer review.

- The final published version features the final layout of the paper including the volume, issue and page numbers.

Link to publication

\footnotetext{
General rights rights.

- You may freely distribute the URL identifying the publication in the public portal. please follow below link for the End User Agreement:

www.umlib.nl/taverne-license

Take down policy

If you believe that this document breaches copyright please contact us at:

repository@maastrichtuniversity.nl

providing details and we will investigate your claim.
}

Copyright and moral rights for the publications made accessible in the public portal are retained by the authors and/or other copyright owners and it is a condition of accessing publications that users recognise and abide by the legal requirements associated with these

- Users may download and print one copy of any publication from the public portal for the purpose of private study or research.

- You may not further distribute the material or use it for any profit-making activity or commercial gain

If the publication is distributed under the terms of Article $25 \mathrm{fa}$ of the Dutch Copyright Act, indicated by the "Taverne" license above, 
Biomarkers in asthmatic inflammation 
(C) H.J. Pennings, Maastricht 1998

ISBN 9090123547

Omslag: artistieke impressie van de "cytokine-soup" (Elise Pennings) Vormgeving en druk: Datawyse | Universitaire Pers Maastricht 


\section{Biomarkers in asthmatic inflammation}

a study of pharmacological immunomodulation, in vitro and in vivo

\section{PROEFSCHRIFT}

ter verkrijging van de graad van doctor aan de Universiteit Maastricht, op gezag van de Rector Magnificus, Prof. dr. A.C. Nieuwenhuijzen Kruseman, volgens het besluit van het College van Decanen, in het openbaar te verdedigen op vrijdag 12 februari 1999 om 14.00 uur

$$
\text { door }
$$

Hermanus Johannes Pennings geboren 3 april, 1959 te Berlicum 


\section{Promotor}

Prof. dr. E.F.M. Wouters

\section{Co-promotor}

Dr. W.A. Buurman

Beoordelingscommissie

Prof. dr. A. Bast (voorzitter)

Prof. dr. C.E. Blanco

Prof. dr. G.J. Dinant

Prof. dr. J.C. de Jongste (Erasmus Universiteit Rotterdam)

Prof. dr. F.P. Nijkamp (Universiteit Utrecht)

Het in dit proefschrift beschreven onderzoek werd financieel mede mogelijk gemaakt door een gift van Glaxo-Wellcome, the Netherlands B.V. 
Non scolae, sed vitae

In herinnering aan mijn grootvader, Hermann Follmer Voor mijn ouders Voor Justine 



\section{Contents}

ABBREVIATIONS/AFKORTINGEN 9

1 General Introduction 11

1.1 Introduction 11

1.2 Asthma: general concepts regarding pathogenesis $\quad 12$

1.3 Development of airway inflammation 13

1.4 The role of the monocyte/macrophage in the pathogenesis of asthma $\quad 14$

1.5 Monitoring of asthma activity 15

1.5.1 Bronchial biopsies 16

1.5.2 Bronchoalveolar lavage 16

$\begin{array}{ll}\text { 1.5.3 Sputum induction } & 17\end{array}$

1.5.4 NO-analysis in exhaled air $\quad 18$

1.5.5 Peripheral blood analysis 19

1.5.6 Markers in urine 25

2 Aim and design of the thesis 39

PART 1: IN VITRO- AND ANIMAL STUDIES

3 Tumor Necrosis Factor- $\alpha$ induces hyperreactivity in tracheal smooth muscle of the guinea-pig in vitro 41

4 Evaluation of immunomodulatory properties of theophylline: an in vitro study in human cells 55

$5 \quad$ Salmeterol and salbutamol decrease TNF- $\alpha$ release in human monocytes

PART 2: BIOMONITORING IN ASTHMATIC PATIENTS

6 Effect of inhaled beclomethasone dipropionate on isocapnic hyperventilation with cold air in asthmatics, measured with forced oscillation technique 
7 Beclomethasone dipropionate attenuates levels of soluble TNF-Receptor- 55 and circulating ICAM-1 in patients with stable asthma

8 Changes in levels of catalase and glutathione in erythrocytes of patients with stable asthma, treated with beclomethasone dipropionate

9 Summary and general discussion

10 Samenvatting en discussie

APPENDICES

A Dankwoord

B List of publications

C Curriculum vitae 


\section{Abbreviations}

\begin{tabular}{|c|c|}
\hline BAL & : bronchoalveolar lavage \\
\hline BCS & : bovine calf serum \\
\hline BDP & : beclomethasone dipropionate \\
\hline BHR & : bronchial hyperresponsiveness \\
\hline cAMP & : adenosine 3',5'cyclic monophosphate \\
\hline CAT & : catalase \\
\hline cGMP & : guanosine 3',5'cyclic monophosphate \\
\hline ECP & : eosinophil cationic protein \\
\hline EPX & : eosinophil protein X \\
\hline ELISA & : enzyme-linked immuno sorbent assay \\
\hline$f_{0}$ & $\begin{array}{l}\text { frequency at which the sum of elastic and } \\
\text { inertial properties equals zero, measured with } \\
\text { FOT }\end{array}$ \\
\hline FCS & : fetal calf serum \\
\hline FD & $\begin{array}{l}\text { : frequency dependence of resistance, measured } \\
\text { with FOT }\end{array}$ \\
\hline $\mathrm{FEV}_{1}$ & : forced expiratory volume in one second \\
\hline $\mathrm{FEV}_{1}$ (\% pred.) & : $\mathrm{FEV}_{1}$ as percentage of the predicted value \\
\hline FOT & : forced oscillation technique \\
\hline FVC & : forced vital capacity \\
\hline GM-CSF & : granulocyte macrophage colony-stimulating factor \\
\hline GPx & : glutathione peroxidase \\
\hline GSH & : glutathione \\
\hline GST & : glutathione S-transferase \\
\hline $\mathrm{Hb}$ & : hemoglobin \\
\hline IFN- $\gamma$ & : interferon gamma \\
\hline $\operatorname{Ig}$ & : immunoglobulin \\
\hline IHCA & : isocapnic hyperventilation with cold air \\
\hline IL- $(4 / 5 / 6 / 8 / 10)$ & : Interleukin- $(4,5,6,8,10)$ \\
\hline IVC & : inspiratory vital capacity \\
\hline LPS & : lipopolysaccharide \\
\hline LT & : leukotriene \\
\hline NO & : nitric oxide \\
\hline PAF & : platelet activating factor \\
\hline PBMC & : peripheral blood mononuclear cells \\
\hline PBS & : phosphate-buffered saline \\
\hline
\end{tabular}


$\mathrm{PD}_{20}$

PEF(R)

PG

$\mathrm{PLA}_{2}$

$\mathrm{R}_{8}$

$\mathrm{R}_{28}$

RBC

ROS

SD

SEM

$s$ E-selectin-1

sICAM-1

sTNF-R55

sTNF-R75

sVCAM-1

SOD

SPSS

TGF $\beta$

Th

TNF $\alpha$

TNFR-p8o: Fc

$\mathrm{X}_{8}$
: provocative dose of inhaled histamine, inducing a $20 \%$ fall in $\mathrm{FEV}_{1}$ from baseline.

: peak expiratory flow (rate)

: prostaglandin

: phospholipase $\mathrm{A}_{2}$

: resistance, measured with FOT at $8 \mathrm{Hertz}$

: resistance, measured with FOT at $28 \mathrm{Hertz}$

: red blood cells

: reactive oxygen species

: standard deviation

: standard error of the mean

: soluble Endothelial Cell Adhesion Molecule-1

: soluble Intercellular Adhesion Molecule-1

: soluble TNF-receptor-55 (I)

: soluble TNF-Receptor-75(II)

: soluble Vascular Cell Adhesion Molecule-1

: superoxide dismutase

: Statistical package for the Social Sciences

: transforming growth factor $\beta$

: T-helper lymphocyte

: tumor necrosis factor- $\alpha$

: soluble human TNF-Receptor (p80) linked to the Fc-portion of human IgG,

: reactance, measured with FOT at 8 hertz 


\section{CHAPTER 1 \\ General introduction}

\subsection{INTRODUCTION}

Asthma was already recognized in ancient times as a pathological condition and described by Hippocrates and Maïmonides. The involvement of inflammation in the pathogenesis of asthma was suggested in 1892 by Osler [1]. In 1922, this hypothesis was confirmed by the demonstration of airway inflammation in lungs of asthmatic patients [2]. Despite the introduction of powerful anti-inflammatory drugs in the treatment of asthma, asthma still represents a major cause for respiratory health care occupation and economical health care consumption $[3,4]$. Asthma is still responsible for a great number of deaths, occurring within the group of patients with chronic pulmonary disease, despite the tremendous increase in knowledge, concerning pathophysiology and treatment of asthma [5]. At the present time, the working definition of asthma discerns three major characteristics in asthma i.e. 1:) the presence of variable airway obstruction, 2:) the presence of bronchial hyperreactivity, and 3:) the presence of bronchial inflammation $[5,6,7]$. Variable airflow-obstruction may be recognized by a pattern of one or more characteristic symptoms, including wheezing, chest tightness, cough and dyspnea. However, the diagnosis of asthma should be further supported by the observation of variable or reversible airflow-obstruction [8]. Bronchial hyperresponsiveness (BHR), defined as an increased reponsiveness of airways to a variety of specific and non-specific stimuli [9], is generally present in asthma, but an overlap with the normal population exists $[10,11]$. In general, levels of BHR correlate with the seriousness of asthmatic disease [12].

With the development of invasive techniques, insight grew that asthma represented an inflammatory disease. Studies observed that asthma is not solely a smooth muscle disease, but involves the presence of local injury, followed by inflammatory cell influx in bronchial tissue. In asthma, characteristic inflammatory changes are detectable in the bronchial epithelium and lamina propria, as has been observed in bronchial biopsies $[13,14,15,16]$. Characteristical changes include epithelial shedding, increased thickness of the basement membrane and increased numbers of activated mast cells [17], eosinophils [18,19,20], lymphocytes $[20,21]$, macrophages $[20,22,23]$ and epithelial cells [24,25]. Vignola et al.[26] observed that, even in patients with intermittent asthma, increased epithelial shedding and thickening of the basement membrane is present. Several studies have 
observed correlations between levels of bronchial inflammation and respectively bronchial hyperresponsiveness $[20,21,24,27,28,29]$ and asthma severity $[18,20]$.

\subsection{Asthma: general concepts regarding pathogenesis}

Asthma and atopy are closely related; the presence of atopy increases the risk of developing asthma during life by a factor $10-20$ in comparison to non-atopic individuals. Human gene linkage studies have identified several genes, that may be associated with both atopic disease and asthma [30,31,32]. Positive linkages have been reported for genes, located on chromosome 5, and encoding for cytokines, which activate mast cells, basophils and eosinophils; recently, it was reported that, also on chromosome 5, a gene, which governs bronchial hyperresponsiveness is located near a gene that regulates $\mathrm{IgE}$ levels [33]. On chromosome 6 , linkages have been detected for genes encoding for HLA, which are involved in antigen presentation, and for genes, encoding for TNF $\alpha$, a proinflammatory cytokine, which is implicated in the pathogenesis of asthma. Atopic disease is characterized by the presence of allergen-specific $\mathrm{IgE}$ in serum and a set of cytokines, derived from $\mathrm{T}(\mathrm{h} 2)$-lymphocytes (Il-4, Il-10 and IL-13), is pivotal in mediating IgE production and the development of immediate hypersensitivity [34]. Interestingly, Th2 derived cytokines are also involved in the pathogenesis of asthma (see paragraph 1.3)[35]. The designation of T-lymphocyte subsets as Th1 or Th2 is based on observations in murine $\mathrm{T}$ cell clones, which were divided on the basis of expression of messenger RNA and cytokine release [36]; Th1 cells produce IL-2, IFN- $\gamma$, and lymphotoxin (TNF $\beta$ ) and are involved in cell-mediated immune responses e.g. delayed type-hypersensitivity. Th2 cells produce IL-4,-5,-6,-9,-10 and -13, and are involved in the humoral response to, for instance, parasitic infections [37]. Both Th1 and Th2-type lymphocytes produce IL-3, GM-CSF and TNF $\alpha$ [37]. In recent years, it became clear that, besides hereditary traits, environmental factors are involved in the further development towards asthmatic disease. Already at birth, peripheral blood T-lymphocytes of babies, born of atopic mothers, respond to aeroallergens [38]. Further allergen-exposure in early infancy may provide the stimulus for sensitization of the lower airways [39], directing T-lymphocyte response towards a Th2-type response. This is especially critical, since peripheral blood mononuclear cells in infants, who develop atopic disease, have been shown to be deficient in the production of IFN- $\gamma[40,41]$, which inhibits the Th2 response. In contrast, recurrent respiratory tract infections, like measles and whooping cough, may switch the Th-response towards the Thl-type response, including release of IL-12, IFN- $\gamma$ and TNF $\alpha$ [42]; in Japanese school children, a strong inverse relationship was observed between delayed type hypersensitivity (DTH) to Mycobacterium Tuberculosis as observed after immunization with BCG (bacillus Calmette-Guérin) and atopy [43]; children with higher levels of DTH had a re- 
duced incidence in atopy and asthma and demonstrated a Th1-like cytokineprofile in peripheral blood. However, the idea of asthma as a Th2-mediated disease seems too simple; in BAL, no differences were observed in IFN- $\gamma$ expression in cells of asthmatic patients and healthy volunteers [35], and in severe asthma it was shown that airway T-lymphocytes have an enhanced capacity to generate both IL- 4 and IFN- $\gamma[44,45]$. Therefore, the description of asthma as a pure Th2response should be reconsidered, since the observed cytokine profile may be the result of exogenous regulators, which stimulate the expression of individual cytokines $[46,47]$.

\subsection{Development of airway inflammation}

Dendritic cells are considered to represent the first step in the development of the asthmatic inflammation, since they capture, process and present allergens to $T$ lymphocytes [48]. Il-4 and TNF $\alpha$ can upregulate both the high- and low-affinity $\mathrm{IgE}$ receptors on dendritic cells, which increases their capturing and processing capacity [49]. The processed antigens are, together with MHC class II molecules, presented to T-lymphocytes in the regional lymph-nodes. Presentation of the antigen to CD4 T-lymphocytes leads, in susceptible individuals, to the development of Th2-type lymphocytes, capable of the production and secretion of specific cytokines (see paragraph 1.2). The local balance of cytokines determines the direction of the $\mathrm{T}(\mathrm{h} 0)$ response; antigen-presenting cells may release IL-12 or IFN- $\gamma$, which promote a Th1 response, whereas Il- 4 and IL- 10 promote a Th 2 cell proliferation [50]. Il-4 (and IL-13) is also responsible for the B-cell isotype switching to $\mathrm{IgE}$ production [51]. T-cell released cytokines (IL-3, Il-4, IL-5 and GM-CSF) activate mast cells and eosinophils, leading to the release of preformed and newly formed mediators. Also, antigen-induced crosslinking of cell-bound $\operatorname{IgE}$ on the surface of mast cells, may result in a direct activation with subsequent release of histamine, prostaglandins and leukotrienes. Moreover, mast cells release a diversity of preformed and newly generated mediators, including IL-4,-5,-6,-8,-13, GM-CSF and TNF $\alpha$ [52,53]. Release of histamine and cytokines (especially TNF $\alpha$ ) leads to an increased expression of adhesion molecules (ICAM-1, E-selectin-1, VCAM-1) on the cell surface of epithelial [54] and endothelial cells, resulting in an influx of inflammatory cells (T-lymphocytes, monocytes and eosinophils) in the bronchial mucosa [55]. The local presence of IL-3, IL-5, GM-CSF and TNF $\alpha$ leads to the subsequent differentiation, growth and activation of eosinophils $[56,57,58]$, resulting in the release of eosinophil activation products (ECP, EPX, major basic protein). The importance and clinical relevance of the monitoring of these eosinophilic products will be discussed later on. Activated eosinophils also generate new mediators, like leukotriene $\mathrm{C}_{4}$, prostaglandins ( $\mathrm{PGE}_{1}$ and $\mathrm{PGE}_{2}$ ), platelet activating factor and oxygen derived radicals, which may induce consider- 
able tissue damage [56]. The main target for mast cells and eosinophils for inducing tissue damage is the bronchial epithelium $[59,60]$, which becomes fragile and looses its protective function, thus exposing underlying structures to inhaled substances and perpetuating the inflammatory reaction with subsequent generation of bronchial hyperresponsiveness [28]. The cascade of interacting and amplifying mediators ultimately leads to the chronic airway inflammation, characteristic for asthma.

\subsection{The role of the monocyte/macrophage in the pathogenesis of asthma}

In the lung, four subpopulations of macrophages are present: the alveolar macrophage, the interstitial and the intravascular macrophage and the various accessory cells, such as dendritic cells or Langerhans' cells [61]. Two mechanisms are involved in maintaining the population of alveolar and interstitial macrophages i.e. chemotactic attraction of monocytes from the peripheral blood and local replication within the lung. Bone marrow derived monocytes migrate into the alveoli both during steady-state conditions, as well as during acute inflammatory events $[62,63,64]$. In addition, inflammatory events induce an increased proliferation of interstitial macrophages [65].

Since alveolar macrophages are easily accessible by bronchoalveolar lavage, most data in clinical studies reflect observations in alveolar macrophages. Macrophages possess complement receptors, receptors for $\mathrm{IgG}$ and low-affinity receptors for $\mathrm{IgE}$ [66]. In addition, receptors for macrophage-activating cytokines like IL-1, TNF $\alpha$ and IFN- $\gamma$ have been described, as well as receptors for macrophage-deactivating cytokines, like IL- 4 and IL-10 $[67,68]$. Since TNF $\alpha$ and IFN- $\gamma$ are secreted by macrophages, they activate, in an autocrine fashion, the same cell population. Upon activation, macrophages produce arachidonic acid metabolites (both prostaglandins and leukotrienes) and generate reactive oxygen species (ROS), which play an important role in the intra- and extracellular defence mechanisms against micro-organisms. Following activation with bacterial lipopolysaccharides or viruses, alveolar macrophages produce cytokines (IL-1,-6,-8 and TNF $\alpha$ ), growth factors (TGF- $\beta$, fibroblast growth factors, platelet-derived growth factor) and colony-stimulating factors $[61,69,70]$. Because of these inflammatory and immuno-regulatory properties, macrophages and their precursor cells, monocytes, are considered to represent pivotal cells, involved in the pathophysiology of inflammatory lung disease.

Several studies have demonstrated an important role of mononuclear phagocytes in the pathophysiology of the asthmatic inflammation. In asthma, the number of alveolar macrophages, that express the low affinity receptor for $\operatorname{IgE}$ (FcERII), is increased $[71,72]$; in normal conditions, $5-10 \%$ of the macrophages express the IgE-receptor, whereas in asthma this number is increased to $20 \%$. Increased num- 
bers of (activated) macrophages have been observed in BAL fluid in the late asthmatic response $[72,73]$ as well as in bronchial mucosa of asthmatic patients; many of these macrophages display phenotypic characteristics of blood monocytes [72]. Alveolar macrophages of patients with allergic disease are activated in comparison to nonallergic patients $[26,70,74]$, and inhibitory effects on cytokine-release, as induced by IL-4, are decreased [68]. However, macrophages play a dual role in the asthmatic inflammation. Macrophages present antigens to T-lymphocytes and initiate lymphocyte response by release of IL-1, which stimulates Il- 2 receptor (CD25) expression on T-lymphocytes. In turn, Il-2 stimulates T-lymphocyte differentiation and induces the release of IL- 4 , which enhances the Th2 response. However, activated macrophages from allergic patients also produce a $\mathrm{T}$ lymphocyte suppressing mediator [75], suggesting, that alveolar macrophages may also serve to limit proliferative responses in the lower respiratory tract [76]. In peripheral blood, monocytes from asthmatic patients demonstrated an increased expression of the complement receptor, both in stable asthma [77], as well as after allergen bronchoprovocation $[78,79]$. Also monocytes of asthmatic patients released more GM-CSF, both in steady state as well as after stimulation [70]. In addition, studies have shown that in occupational asthma, peripheral blood monocytes are also activated [80].

Of further importance is the fact, that several mediators (TNF, TGF- $\beta$, fibronectin) released by macrophages, possess fibrogenic activity $[61,72]$ and may contribute to the observed airway remodelling in asthma. Also, the increased release of reactive oxygen species, as observed in peripheral blood monocytes $[81,82]$ and alveolar macrophages [83], contribute to the observed airway hyperresponsiveness and airway remodelling in asthma [84].

\subsection{Monitoring of asthma activity}

Assessment of the intensity of airway inflammation in the individual asthmatic patient may serve a number of purposes: to optimize medical treatment, to prevent or to detect in an early stage an imminent exacerbation of asthma and, if possible, to detect ongoing inflammation, which may result in the development of an irreversible stage of airway remodelling in the long run [85]. To date, there exists no "gold standard", which adequately reflects asthma severity and which may guide therapeutic interventions. Up till now, assessment of asthma severity was mainly performed by analysing the recent history of complaints (asthma-symptom score), the degree of airway obstruction and the amount of drugs used, with emphasis placed on the use of relievers (i.e. inhaled $\beta_{2}$-adrenoceptor agonists). Recently, several guidelines have been published regarding therapeutic strategies in asthmatreatment; however, treatment diagrams are all guided by clinical parameters, such as symptom-scores and lung-function parameters (like spirometry, peak flow re- 
cordings) [5,7], whereas the underlying hypothesis is centered on the concept of the reversal and control of asthmatic airway inflammation $[5,7,86]$. In this section, a review will be provided regarding the techniques, which are currently available for the assessment of asthmatic airway inflammation and their (potential) role in the clinical management of asthma will be discussed.

\subsubsection{Bronchial biopsies}

Several studies have evaluated airway inflammation by performing bronchial biopsies and the intensity of inflammation was compared with asthma severity (assessed according to the Aas-score [87]) $[18,20,26,54]$. The studies demonstrated that the total number of eosinophils in peripheral blood, in BAL and within the epithelium of asthmatic patients correlated with asthma severity [18]. Also, the activation status of T-lymphocytes and eosinophils in bronchial mucosa of asthmatic patients was shown to correlate with both Aas asthma symptom score and bronchial hyperresponsiveness [20]. Recently, consensus was reached regarding a new classification of asthma, ranging from intermittent to severe chronic asthma [5]. Vignola et al. [26] observed a correlation between activated eosinophils and T-lymphocytes and asthma-severity in patients with intermittent and chronic asthma, according to the new classification. Although these studies may suggest that bronchial biopsies can be used to monitor the treatment of asthmatic patients, so far, bronchial biopsies are not recommended for routine use [88], since they represent an invasive technique and little is known of their role in the clinical assessment of the individual asthmatic patient. Several studies have shown the usefulness of bronchial biopsies in the monitoring of effects of pharmaceutical interventions in groups of asthmatic patients. Treatment with inhaled corticosteroids has been shown to decrease both the number of inflammatory cells as well as their activation status $[13,89-94]$. However, these studies all evaluated relatively short term effects of inhaled corticosteroids. In contrast, a recent study, evaluating bronchial inflammation in patients treated for a mean duration of 21 months with inhaled corticosteroids, observed a dissociation between levels of bronchial inflammation and asthma symptoms [95]. Although a relationship still existed between levels of inflammation and bronchial hyperresponsiveness, no correlation could be observed between asthma symptoms and the number of inflammatory cells in the bronchial mucosa. This would imply that clinical scores of asthma do not accurately reflect bronchial inflammation in patients, treated with corticosteroids.

\subsubsection{Bronchoalveolar lavage}

Bronchoalveolar lavage is also used for the assessment of inflammation in the airways. Since this technique is also performed by bronchoscopy, it represents an in- 
vasive technique. So far, no consensus exists as to the exact procedure. Differences concern the required volume of instilled fluid, the dwell time within the lung and standardization of the procedure required to analyse the BALF, since the cellular composition of the returned fluid can vary with the aliquot size [96]. Because of the large dilution effects of the instilled fluid in BAL samples, often concentration of BAL fluid is necessary before measurements of various inflammatory mediators can be performed. Moreover, for investigational purposes, a control group should be available, which should have undergone the same procedure in order to make comparisons. In asthma, BAL-studies have shown that increased numbers of eosinophils are present $[18,35,97]$, which are activated, as has been shown by increased levels of ECP in BAL $[18,97]$; both were demonstrated to correlate with asthma-severity. Also, lymphocytes may be increased in BAL of asthmatic patients [98]; however, this does not represent a common finding [99]. Studies clearly show, that although total cell numbers in BAL may not be very different, BAL lymphocytes and leucocytes are clearly activated, even in mild stable asthma $[45,100,101,102]$. In addition, BAL has also been used to study the mechanism, involved in the pathogenesis of the late asthmatic response [103,104,105,106]. BAL has also been used to evaluate the effects of pharmaceutical interventions in groups of asthmatic patients; treatment with inhaled corticosteroids resulted in the reduction in the number of eosinophils and ECP-levels in BAL of asthmatic patients $[107,108]$. Also, inhaled corticosteroids reduced the number of activated $\mathrm{CD} 25^{+} \mathrm{CD} 44^{+} \mathrm{T}$-lymphocytes [109], as well as cytokine levels in BAL of stable asthmatic patients [110]. In general, observations in BAL parallel the changes observed in bronchial biopsies in asthma $[111,112]$.

\subsubsection{Sputum induction}

Due to their invasive character and since, up till now, bronchoscopic techniques (i.e. bronchial biopsies and $\mathrm{BAL}$ ) have not been demonstrated to provide information necessary for the treatment of the individual patient with asthma, these techniques are not recommended for monitoring of asthma. However, the recently developed technique of sputum induction represents a non-invasive technique for the assessment of airway inflammation. So far, this technique has been used almost exclusively in a clinical research setting, and whether this technique is also useful for the monitoring of inflammation in the individual patient still needs to be evaluated. The technique consists of the inhalation of hypertonic aerosol through an ultrasonic nebulizer. Safety procedures are necessary, because hypertonic saline can cause severe airway obstruction in asthmatic patients, which can be diminished by pretreatment with inhaled $\beta_{2}$-agonists. Analysis of cellular compounds of the sputum can be performed in the whole sample or in the viscid portion of the sputum sample [113], whereas various soluble mediators can be measured in the 
supernatant. Of importance is, that the added liquefier (dithiothreitol $0.1 \%$ ) does not interfere with the assays. Clinical studies so far have shown that sputum induction is relatively safe in mild or controlled asthma. The validity and repeatability of differential cell counts within patients have been reported to be good in the hands of skilled investigators $[114,115,116]$.In addition to the evaluation of the cellular components $[117,118]$, in supernatant measurements can be performed regarding mediators such as ECP $[119,120,121]$, histamine, tryptase, neutrophil-activation products [122] and several cytokines, e.g. TNF $\alpha$ and IL-5 [123,124]. In comparison to BAL, induced sputum contains more neutrophils and eosinophils than BAL $[111,125,126]$, whereas numbers of macrophages and lymphocytes are lower in induced sputum. A good correlation was observed between the number of eosinophils in induced sputum and BAL $[111,112,127]$, whereas the correlation with the number of eosinophils in bronchial mucosa is less clear [111,112]. Studies, using allergen challenge, have shown that changes in induced sputum parallel changes in BAL i.e. a rise in the percentage of eosinophils [128], ECP and histamine [129]. Treatment with inhaled or oral corticosteroids has been shown to reduce the number of eosinophils $[121,130]$ and to reduce levels of ECP in induced sputum $[121,130]$.

However, despite these observations, the clinical accuracy of induced sputum as a marker of asthmatic inflammation remains to be established, as well as whether subtle changes in pharmaceutical treatment are reflected by changes in constituents of induced sputum. So far, no gold standard exists for the performance and analysis of induced sputum. Moreover, reference values regarding the normal range remain to be established as well as further optimization of the technique. In regard to the option of using induced sputum analysis in the serial assessment of airway inflammation in individual patients, it is of importance to consider observations from recent studies, which have shown that sputum induction in itself induces changes in airway inflammation within a time-period of 24 hours after sputum induction $[131,132]$.

\subsubsection{NO-analysis in exhaled air}

Nitric oxide (NO) is produced by a variety of cells both in the upper as well as the lower airways. Constitutive nitric oxide synthase (cNOS), which is expressed in endothelial cells (eNOS) and neural cells (nNOS), gives rise to NO, which acts locally either as a vasodilator or neurotransmitter. Inducible NOS (iNOS) is synthesized de novo in macrophages and epithelial cells due to gene activation following inflammation and can induce large quantities of NO [133,134]. Studies suggest that iNOS is present in epithelial cells in asthmatic airways, whereas it is not expressed in epithelial cells from healthy individuals [135]. iNOS can be induced by endotoxins [136] and by inflammatory cytokines like TNF $\alpha$ [135], IL-1 $\beta$ and in- 
terferon- $\gamma$ and the resulting product $\mathrm{NO}$ can be detected in exhaled air in humans $[137,138]$. Several studies have observed a marked increase in NO in exhaled air of asthmatic patients in comparison to controls $[139,140,141]$. Also, increased concentrations of $\mathrm{NO}$ were observed in the late asthmatic reaction after allergen challenge, whereby levels of NO reflected the size of the late response [142]. However, so far, there exists no certainty regarding the cellular origin of the measured NO and the pathophysiological consequences of increased concentrations of $\mathrm{NO}$ are still not clear. NO induces bronchodilation $[133,134]$, but, on the other hand, also increases blood flow in the lung with the possible consequence of increased plasma exudation in the asthmatic airways. NO may further have detrimental effects, since high concentrations of NO have been shown to inhibit Th1 lymphocytes and inhibit production of interferon- $\gamma$ [143]. Although measurements of $\mathrm{NO}$ in exhaled air contain significant contributions of NO, originating from the nose and pharynx, several procedures have been developed in order to increase the reproducibility of the measurements of NO, originating from the lower airways [134]. Nitric oxide analysis in exhaled air has also been demonstrated to be of use in the assessment of asthma in children [144,145]. Up till now, studies have not evaluated response of exhaled NO during long-term treatment of asthma with corticosteroids. Recently, corticosteroids have been shown to inhibit iNOS activity [146] and one study observed that asthmatic patients, using inhaled corticosteroids, showed NO levels in exhaled air comparable to levels in healthy subjects [140]. Also in acute episodes of asthma, an increase in NO levels was observed, that decreased during treatment [147].

In summary, nitric oxide measurement in exhaled air represents a non-invasive technique, which has the potential to detect inflammatory changes within the human airways. However, additional studies have to be performed before this technique can be of use in the evaluation of asthma activity within the individual patient. Further standardization of the technique [148] and the development of normal ranges of $\mathrm{NO}$ concentrations in exhaled air in normal individuals are necessary, before measurements of $\mathrm{NO}$ in exhaled air can be of use in the assessment of asthma in daily practice.

\subsubsection{Peripheral blood analysis}

Except for NO measurements in exhaled air, the methods mentioned above all represent more or less invasive techniques with potential hazards to the patient. For clinical purposes, it is important to monitor asthmatic patients by means of relatively simple and reproducible techniques. The methods used so far in the clinical asessment of patients, all depended on individual cooperation. Diaries and peak flow rate determination have been shown to be useful in asthma management diagrams [5,7], but do not reflect directly levels of airway inflammation [95] or 
predict relapses [149]. Therefore, detection of biomarkers in peripheral blood, which are directly related to the asthmatic inflammation and can be measured in a reproducible, standardized way, should be of interest in the clinical assessment of asthmatic patients. Ideally, biomarkers should be specific for and primarily involved in the pathogenesis of asthmatic disease, should not be related to other diseases and should have been demonstrated to reflect asthma activity in clinical studies. In previous years, several biomarkers have been presented, which have been reported to reflect asthmatic inflammation, but could not live up to all the criteria described above. To date, efforts are still in progress to find an easy to handle biomarker of asthmatic inflammation, which can be used in daily clinical practice. In this section, a review will be given regarding the mediators, currently in use for the evaluation of asthma activity, although most of them are still only used in experimental or investigational settings.

\section{Eosinophils and eosinophil derived mediators}

Eosinophils are among the first cells described to be involved in the asthmatic process and increased numbers of eosinophils have been observed in peripheral blood of asthmatic patients $[18,150,151]$. In groups of asthmatic patients, blood eosinophilia correlated with disease severity $[18,152]$, and in individual patients peripheral blood eosinophils have been shown to fluctuate according to disease activity. After allergen challenge, numbers of peripheral blood eosinophils were shown to decrease at first [153,154] and increase later on [155], whereas in BAL a significant rise in (activated) eosinophils is observed during the late allergic reaction $[156,157,158]$. In addition, an inverse correlation was observed between the number of peripheral blood eosinophils and bronchial hyperreactivity $[152,155]$. Peripheral blood eosinophils of asthmatic patients have been shown to be activated $[159,160]$. Upon activation, eosinophils release preformed mediators [56], like eosinophil cationic protein (ECP), major basic protein, eosinophil protein X (EPX) and eosinophil peroxidase (EPO). Treatment with corticosteroids has been shown to decrease both total number of blood eosinophils as well as their activation status $[161,162,163]$.

\section{Eosinophilic cationic protein (ECP)}

Serum levels of ECP are increased in asthmatic patients in comparison to healthy controls $[164,165,166,167]$ and serum ECP was shown to be increased after antigen challenge $[164,168]$. ECP levels in serum are considered to reflect clinical asthma activity $[169,170]$ and were shown to correlate with the number of activated eosinophils in the bronchial mucosa of asthmatic patients [171]. So far, especially in children, serum ECP is considered to be of diagnostic value for the di- 
agnosis of asthma [172,173,174]. Moreover, several authors have reported beneficial results in asthma treatment in children, using serum ECP as an additional marker of eosinophil activation [175]. In asthmatic patients, treated with corticosteroids, ECP levels decreased in BAL, sputum and in serum [176,177], although response parameters showed a better correlation with sputum ECP than with serum ECP [177]. One study, adjusting inhaled corticosteroid treatment according to serum ECP levels, observed an improvement in pulmonary function in combination with lower levels of ECP, although no changes were observed in bronchial hyperresponsiveness [178]. However, ECP is not specific for the asthmatic inflammation; increased levels of ECP have been observed in eczema, atopy [179], allergic rhinitis [180], respiratory syncytial virus infections [181] and parasitic infections [182]. Therefore, although it is generally accepted that levels of ECP reflect the activation status of eosinophils, the usefulness of serum ECP in the treatment of asthmatic patients in combination with allergic disease, i.e. allergic rhinitis, still remains to be investigated. Also, additional studies are needed to evaluate the usefulness of serum ECP as a single marker in the monitoring and treatment of asthmatic inflammation, especially since correlations of ECP with levels of bronchial hyperresponsiveness are low $[167,183]$. Similar conclusions can be drawn with regard to the determination of eosinophil protein $\mathrm{X}$, both in serum as well as in urine.

\section{Cytokines}

In asthma, T-lymphocytes, monocytes and eosinophils in peripheral blood have been shown to be activated and release, either spontaneously or after stimulation, increased amounts of cytokines and express activation markers on their cell surface $[45,184,185]$, which can be detected in blood. Also mediators, produced within the pulmonary compartment, may leak into the peripheral circulation and can be detected [106]. Although several studies have shown, that differences exist between levels of cell activation between blood and the pulmonary compartment $[101,186]$, studies have evaluated the usefulness of these markers in the monitoring of asthmatic inflammation, although for detection of these inflammatory mediators sensitive assays are required. Up till now, the relationship between levels of these mediators and functional abnormalities, observed in asthma, is ill-defined. Levels of mediators, measured in the general circulation, only partially reflect local concentrations in the pulmonary compartment, and allows only prudent interpretation, regarding the concentration of mediators on tissue level. 
In asthma, T-lymphocytes are activated, not only within the lung [187], but also in the general circulation $[184,188]$. In acute asthma, the expression of the IL-2 receptor (IL-2R), HLA-DR and VLA-1 on T-lymphocytes is increased [184,189] and correlates with asthma activity [190]. In stable asthma, peripheral blood Tlymphocytes were shown to be activated, as was shown by the upregulation of the receptor for IL-2 (CD25), which can be detected in soluble form (sIL-2R) $[191,192]$. Moreover, sIL-2R levels are increased in unstable asthma and decrease following treatment $[188,193]$. Treatment of severe asthma with cyclosporin was shown to result in a clinical improvement, that was associated with a decrease in serum concentrations of sIL-2R [194].

Several other cytokines have been measured in blood of asthmatic patients. Serum IL- 4 has been shown to be increased in asthmatic patients versus healthy subjects [195,196]; especially in atopic children, increased levels of IL-4 have been observed, which correspond with an increased tendency of peripheral blood cells to produce IL-4 [197]. Il-4 was shown to be increased in adult patients with asthma, who also demonstrated enhanced levels of sIL-2R and soluble low affinity receptor for IgE (sCD23) [192]. In parallel, several studies, especially in children have evaluated the role of the low affinity receptor of $\operatorname{IgE}(s \mathrm{CD} 23)$ in the pathogenesis of asthma and also observed increased levels in young asthmatic patients [198], often in combination with enhanced levels of IL-4 [196]. sCD23 was shown be associated with atopy and showed an age-dependent change [199].

IL-5 is a T-cell derived mediator, which was shown to induce both eosinophilia in $\mathrm{BAL}$ and increase bronchial hyperresponsiveness, when inhaled by asthmatic patients [200]. Il-5 has been shown to be increased in peripheral blood of asthmatic patients [166], although studies in children were only able to detect serum IL-5 in acute asthma [181]. In adult asthmatic patients, Il-5 was detected in serum of patients with severe chronic asthma [201], and following corticosteroid treatment, both serum IL-5 and the number of activated T-lymphocytes in peripheral blood decreased [202].

GM-CSF represents a cytokine, which is involved in eosinophil activation [97] and is released in increased quantities by peripheral blood monocytes and macrophages in asthmatic patients [70]. So far, only one study reported increased levels of GM-CSF in peripheral blood of asthmatic patients [97], whereas an inverse trend was reported in children [195].

IFN - $\gamma$, a Th1 cytokine, has been shown to be involved in the asthmatic inflammation $[35,44,45,47]$. Although studies in stimulated peripheral blood cells suggest a decreased interferon-gamma production [197,203,204], serum interferongamma levels in patients with stable asthma were comparable with levels of healthy controls [205]. 
Although proinflammatory cytokines are implicated in the pathogenesis of asthma $[73,70,104,188]$, measurement of proinflammatory mediators in peripheral blood of asthmatic patients so far has not been proven to be useful. TNF $\alpha$, a proinflammatory cytokine, which is released early in the acute inflammatory response [206], is implicated in the asthmatic airway inflammation $[55,207,208,209]$ and development of bronchial hyperresponsiveness $[124,210,211]$. TNF $\alpha$ is also implicated in the upregulation of adhesion molecules on the cell surface of epithelial [212] and endothelial cells $[206,210]$. So far, few studies were able to detect TNF $\alpha$ in the circulation, and when present, TNF $\alpha$ was only detected in acute exacerbations of asthma $[213,214]$, whereas, in stable disease, no TNF $\alpha$ could be detected [188]. Part of these observations can be explained by the very short halflife of TNF $\alpha$ [215]. Similar observations have been made regarding serum IL-6 levels; serum IL- 6 was significantly elevated in acute exacerbations of asthma, and, in stable asthma, IL-6 levels were found to be comparable with levels in healthy subjects [216]. Recently, the soluble receptor of IL-6 (sIL-6R) was detected in the circulation. In contrast to observations with IL-6, sIL-6R levels were elevated in stable asthmatic patients in comparison with healthy subjects and a further increase was observed in acute asthma and after allergen challenge [217].

Although IL-8 is also implicated in the asthmatic airway inflammation $[70,218]$, no data exist regarding serum levels of IL-8 in asthma.

\section{Soluble TNF-receptors}

TNF-receptors are involved in mediating the effects of TNF $\alpha$ and, following activation, can be shed from the cellular surface [219]. TNF-receptors are present on nearly all cells and two types of TNF-receptors (sTNF-R55 and sTNF-R75) can be detected in healthy subjects [220]. Each TNF-receptor is considered to have a differential role in the regulation of TNF $\alpha$-mediated effects [221,222,223]. Since $\mathrm{TNF} \alpha$ is involved in the asthmatic airway inflammation [73,104,124,210], evaluation of soluble TNF-receptor levels may be of interest in the treatment of asthma. So far, two studies evaluated the presence of sTNF-receptors in asthma $[224,225]$; one study observed increased levels of sTNF-receptors during acute asthma, whereas, following treatment, levels of sTNF-receptor decreased [224]. However, sTNF-receptors are not specific for asthmatic inflammation, since enhanced levels of TNF-receptors have been observed in other diseases $[225,226,227,228,229]$ 
Adhesion molecules are involved in the regulation of leucocyte-trafficking $[230,231]$ and several studies have observed an increased expression of adhesionmolecules in the bronchial mucosa of asthmatic patients [54,232,233,234]. Analogous to TNF-receptors, adhesion-molecules can be shed from the cell surface and have been detected in body fluids of asthmatic patients and healthy subjects $[106,118,235]$. After allergen challenge, increased levels of soluble Intercellular Adhesion Molecule-1 (sICAM-1) were detected in the general circulation $[106,236,237]$ and were considered to reflect the upregulation of adhesion molecules within the asthmatic airways. Increased levels of soluble adhesion molecules (sICAM-1, soluble E-selectin-1) have also been observed in acute asthma $[214,238,239]$. Although studies reported enhanced levels of sICAM-1 and Eselectin in stable asthma $[236,239]$, others could not confirm these observations [238]. Also, conflicting data exist regarding the role and involvement of soluble Vascular Cell Adhesion Molecule-1 (sVCAM-1)in acute asthma [213,238].

Treatment with corticosteroids decreased soluble adhesion molecule levels in some studies [239], although not in all [238]. It should be noted that sICAM-1 and $s E$-selectin-1 are not specific for the asthmatic inflammation, since they are also involved in other inflammatory and allergic diseases [225, 227, 228, 229, $240,241]$

\section{Markers for oxidative stress}

In asthma, alveolar macrophages, peripheral blood monocytes and polymorphonuclear leucocytes have all been shown to generate increased amounts of reactive oxygen species (ROS), which can be measured by chemiluminescence $[81,83,242,243,244]$. The amount of ROS released was observed to correlate with both asthma severity [83] and bronchial hyperreactivity [84,245], and was significantly increased in comparison to healthy subjects [82]. Increased ROS generation is observed after segmental allergen challenge $[246,247]$ and ROS generation in peripheral blood cells is increased even more in unstable asthma [82]. Recently, measurement of whole blood chemiluminescence was demonstrated to represent a systemic parameter, which reflects asthmatic inflammation [248]; whole blood chemiluminescence was shown to correlate with airway obstruction, whereas it was also shown that patients with stable asthma had levels comparable with healthy subjects. More promising for clinical use, is the recent demonstration of increased hydrogen peroxide and thiobarbituric acid-reactive products in expired breath condensate of asthmatic patients $[249,250]$. 


\subsubsection{Markers in urine}

So far, leukotriene $\mathrm{E}_{4}\left(\mathrm{LTE}_{4}\right)$ is the soluble marker in urine studied most extensively [251]. LTE ${ }_{4}$ levels in urine have generally been acccepted as a suitable marker of endogenous formation of cysteinyl-leukotrienes within the body, including the lung. Increases in urine $\mathrm{LTE}_{4}$ have been detected after allergen challenge in asthmatic patients, whereas no changes in urinary $\mathrm{LTE}_{4}$ levels were observed after exercise-induced bronchoconstriction [252]. Determination of urinary EPX, an eosinophil-derived mediator, may represent a new marker for asthmatic inflammation: preliminary data suggest a potential usefulness of urinary EPX in the monitoring of asthma, both in adults [253] and children [254]. In asthmatic children, it was shown that urine levels of EPX correlated both with the number of eosinophils [254] and with asthma activity and pulmonary function [255]. In addition, measurement of urinary $9 \alpha, 11 \beta-\mathrm{PGF}_{2}$ was presented recently as a method to measure mast cell activation in exercise-induced asthma $[256,257]$. However, before the usefulness of these markers in clinical practice can be determined, it is necessary to extend basic information (e.g. the definition of normal values and the effect of different manipulations on these urinary markers). When such studies have been performed, urinary markers may become useful in clinical management of asthmatic patients.

In conclusion, although several techniques are currently available for assessment of asthmatic inflammation, it has not been established yet, which marker or set of markers may be the best reflection of the asthmatic inflammation. Ultimate goal in the treatment of asthmatic patients is to restore the quality of life, control the asthmatic inflammation and to prevent structural changes within the airways. In order to achieve this, the clinician should have access to a sensitive and specific set of markers, which enables him to treat the individual patient with asthma in the best possible way.

\section{REFERENCES}

1. Osler W. Bronchial Asthma. In Osler W. (eds): principles and practice of medicine. New York, D Appleton and Co. 1892, p 497.

2. Huber HL, Koesler KK. The pathology of bronchial asthma. Arch Intern Med 1922; 30: 689-760.

3. Stuurgroep toekomstscenario's gezondheidszorg (STG). Chronische ziekten in het jaar 2005. Deel 4: scenario's voor het beleid. Bohn, Stafleu,Van Loghum. Houten/ Antwerpen 1992.

4. Sears MR. Descriptive epidemiology of asthma. Lancet 1997;350 (suppl II):1-4.

5. WHO/NHLBI Workshop Report. Global stategy for asthma management and prevention. National Institutes of Health, National Heart, Lung and Blood Institute, Bethesda, MD. 1995; Publication No. 95-3659. 
6. Sheffer AL. Guidelines for the diagnosis and management of asthma. National Heart, Lung, and Blood Institute National Asthma Education Program Expert Panel Report. J Allergy Clin Immunol 1991; 88: 425-434.

7. British Thoracic Society. Guidelines on the management of asthma. Thorax 1993; 48: S1-S24

8. Venables KM, Burge PS, Davison AG, Newman-Taylor AJ. Peak flow rate records in surveys: reproducibility of observers' reports. Thorax 1984; 39: 828-832.

9. Hargreave FE, Dolovich J, O'Byrne PM, Ramsdale EH, Daniel EE. The origin of airway hyperresponsiveness. J Allergy Clin Immunol 1986; 78: 825-832.

10. Juniper EF, Frith PA, Hargreave FE. Long term stability of bronchial responsiveness to histamine. Thorax 1982; 37: 288-291.

11. Cockcroft DW, Berscheid BA, Murdock KY. Unimodal distribution of bronchial responsiveness to inhaled histamine in a random human population. Chest 1983; 5: 751-754.

12. Hargreave FE, Ryan G, Thomson NC, O'Byrne PM, Latimer K, Juniper EF, Dolovich J. Bronchial responsiveness to histamine or methacholine in asthma: measurement and clinical significance. J Allergy Clin Immunol 1981; 68: 347-355.

13. Laitinen LA, Laitinen A, Haahtela T. A comparative study of the effects of an inhaled corticosteroid, budesonide, and a beta-2-agonist, terbutaline, on airway inflammation in newly diagnosed asthma: A rondomized, double-blind, parallel-group controlled trial. J Allergy Clin Immunol 1992; 90: 32-42.

14. Laitinen LA, Heino M, Laitinen A, Kava T, Haahtela T. Damage of the airway epithelium and bronchial reactivity in patients with asthma. Am Rev Respir Dis 1985; 131: 599-606.

15. Beasley R, Roche WR, Roberts JA, Holgate ST. Cellular events in the bronchi in mild asthma and after bronchial provocation. Am Rev Respir Dis 1989; 139: 806-817.

16. Djukanovic R, Roche WR, Wilson JW, Beasley CRW, Twentyman OP, Howarth PH, Holgate ST. Mucosal inflammation in asthma. Am Rev Respir Dis 1990; 142: 434-457.

17. Pesci A, Foresi A, Bertorelli G, Chetta A, Olivieri D. Histochemical characteristics and degranulation of mast cells in epithelium and lamina propria of bronchial biopsies from asthmatic and normal subjects. Am Rev Respir Dis 1993; 147: 684-689.

18. Bousquet J, Chanez P, Lacoste JY, Barnéon G, Ghavanian N, Enander I, Venge P, Ahlstad S, Simony-Lafontaine J, Godard Ph, Michel FB. Eosinophilic inflammation in asthma. N Eng/ J Med 1990; 323: 1033-1039.

19. Djukanovic R, Wilson JW, Brittem KM, Wilson SJ, Walls AF, Roche WR, Howarth PH, Holgate ST. Quantitation of mast cells and eosinophils in the bronchial mucosa of symptomatic atopic asthmatics and healthy control subjects using immunochemistry. Am Rev Respir Dis 1990; 142: 863-871.

20. Bentley AM, Menz G, Storz C, Robinson DS, Bradley B, Jeffery PK, Durham SR, Kay AB. Identification of T-lymphocytes, macrophages and activated eosinophils in the bronchial mucosa in intrinsic asthma: relationship to symptoms and bronchial responsiveness. Am Rev Respir Dis 1992; 146: 500-506.

21. Bradley BL, Azzawi M, Jacobson M, Assoufi B, Collins JV, Irani AA, Schwartz LB, Durham SR, Jeffery PK, Kay AB. Eosinophils,T-lymphocytes, mast cells, neutrophils, and macrophages in bronchial biopsy specimens from atopic subjects with asthma: comparison with biopsy specimens from atopic subjects without asthma and normal control subjects and relationship to bronchial hyperresponsiveness. J Allergy Clin Immunol 1991; 88: 661-674.

22. Poston RN, Chanez P, Lacoste JY, Litchfield T, Lee TH, Bousquet J. Immunohistochemical characterization of the cellular infiltration in asthmatic bronchi. Am Rev Respir Dis 1992; 145: 918-921.

23. Poulter LW, Janossy G, Power C, Sreenan S, Burke C. Immunological/physiological relationships in asthma: potential regulation by lung macrophages. Immunol Today 1994; 15 : 258-261. 
24. Jeffery PK, Wardlaw AJ, Nelson FC, Collins JV, Kay AB. Bronchial biopsies in asthma: an ultrastructural, quantitative study and correlation with hyperreactivity. Am Rev Respir Dis 1989; 140: 1745-1753.

25. Roisman GL, Lacronique JG, Desmazes-Dufeu N, Carre C, LeCae A, Dusser DJ. Airway responsiveness to bradykinin is related to eosinophilic inflammation in asthma. Am J Respir Crit Care Med 1996; 153: 381-390.

26. Vignola AM, Chanez P, Campbell AM, Souques F, Lebel B, Enander I, Bousquet J. Airway inflammation in mild intermittent and persistent asthma. Am J Respir Crit Care Med 1998; 157: 403-409.

27. Kay AB. inflammatory cells in bronchial asthma. J Asthma 1989; 26: 335-344.

28. Barnes PJ. New concepts in the pathogenesis of bronchial hyperresponsiveness and asthma. J Allergy Clin Immunol 1989; 83: 1013-1026.

29. Chetta A, Foresi A, Del Donno M, Consigli GF, Bertorelli G, Pesci A, Barbee RA, Olivieri D. Bronchial responsiveness to distilled water and methacholine and its relationship to inflammation and remodeling of the airways in asthma. Am J Respir Crit Care Med 1996; 153 : 910-917.

30. Daniels SE, Bhattacharrya S, James A, Leaves NI, Young A, Hill MR, Faux JA, Ryan GF, Le Souef PN, Lathrop GM, Musk AW, Cookson WO. A genome-wide search for quantitative trait loci underlying asthma. Nature 1996; 383: 247-250.

31. Sandford A, Weir T, Pare P. The genetics of asthma. Am J Respir Crit Care Med 1996; 153: 1749-1765.

32. Holgate ST. The cellular and mediator basis of asthma in relation to natural history. Lancet 1997; 350 (suppl II): 5-9.

33. Postma DS, Bleecker ER, Amelung PJ, Holroyd KJ, Xu J, Panhuysen CIM, Meyers DA, Levitt RC. Genetic susceptibility to asthma-bronchial hyperresponsiveness coinherited with a major gene for atopy. N Engl J Med 1995; 333: 894-900.

34. Carballido JM, Carballido-Perrig N, Terres G, Heusser CH, Blaser K. Bee venom phospholipase A-2 specific $T$ cell clones from human allergic and non-allergic individuals: cytokine patterns change in response to the antigen concentration. Eur J Immunol 1992; 22: 1357-1363.

35. Robinson DS, Hamid Q, Sun Y, Tsicopoulos A, Barkans J, Bentley AM, Corrigan C, Durham SR, Kay AB. Predominant Th2-like bronchoalveolar T-lymphocyte population in atopic asthma. $N$ Engl J Med 1992; 326: 298-304.

36. Mossman TR, Cherwinski HM, Bond MW, Giedlin MA, Coffman RL. Two types of murine helper T cell clone. Definition according to the profiles of lymphokine activities and secreted proteins. J Immunol 1986; 136: 2348-2357.

37. Mossmannn TR, Sad S. The expanding universe of T-cell subsets; Th1, Th2 and more. Immunol Today 1996; 17: 138-146.

38. Miles EA, Warner JA, Jones AC, Collwell BM, Bryant TM, Warner JA. Peripheral blood mononuclear cell proliferation responses in the first year of life in babies born of allergic parents. Clin Exp Allergy 1996; 26: 780-788.

39. Sporik R, Holgate ST, Platts-Mills TAE, Cogswell JJ. Exposure to house dust mite allergen (Der $P_{\text {, }}$ ) and the development of asthma in childhood: a prospective study. N Eng/ J Med 1990; 323: 502-507.

40. Warner JA, Miles EA, Jones AC, Quint DJ, Collwell BM, Warner JA. Is deficiency of interferongamma production by allergen triggered cord blood cells a predictor of atopic eczema. Clin Exp Allergy 1994; 24: 423-430.

41. Tang ML, Kemp AS, Thorburn J, Hill DJ. Reduced interferon-gamma secretion in neonates and subsequent atopy. Lancet 1994; 344: 983-985.

42. Fearon DT, Locksley RM. The instructive role of innate immunity in the acquired immune response. Science 1996; 272: 50-53.

43. Shirakawa T, Enomoto T, Shimazu S, Hopkin JM. The inverse association between tuberculin responses and atopic disorder. Science 1997; 275: 77-79. 
44. Krug N, Madden J, Redington AE, Lackie P, Djukanovic R, Schauer U, Holgate ST, Frew AJ, Howarth PH. T-cell cytokine profile evaluated at the single cell level in BAL and blood in allergic asthma. Am J Respir Cell Mol Biol 1996; 14: 319-326.

45. Cembrzynska-Nowak M, Sklarz E, Inglot AD, Teodorczyk-Injeyan JA. Elevated release of Tumor necrosis factor-alpha and Interferon-gamma by bronchoalveolar leucocytes from patients with bronchial asthma. Am Rev Respir Dis 1993; 147: 291-295.

46. Kelso A. Th1 and Th2 subsets: paradigms lost?. Immunol Today 1995; 16; 374-379.

47. Krouwels FH, Hol BE, Bruinier B, Lutter R, Janssen HM, Out TA. Cytokine production by T-cell clones from bronchoalveolar lavage fluid of patients with asthma and healthy subjects. Eur Respir J 1996; 22(suppl): 95-103s.

48. Semper AE, Hartley JA. Dendritic cells in the lung: what is their relevance to asthma? Clin Exp Allergy 1996; 26: 485-490.

49. Hartley JA, Semper AE, Holgate ST. In vivo and in vitro expression of FCRI in human peripheral blood (PB). Immunology 1996; 89 (suppl I): 41.

50. Hsieh CS, Heimberger AB, Gold JS, O'Garra A, Murphy KM. Differential regulation of T-helper phenotype by interleukins- 4 and -10 in an $\alpha-\beta$ T-cel receptor transgenic system. Proc Nat/ Acad Sci USA 1992; 89: 6065-6069.

51. Pène J, Rousset F, Brière F, Chrétien I, Paliard X, Banchereau J, Spits H, De Vries JE. IgE production by normal human $B$ cells induced by alloreactive T cell clones is mediated by IL- 4 and suppressed by IFN- $\gamma$. J Immunol 1988; 141: 1218-1224.

52. Bradding P, Holgate ST. The mast cell as a source of cytokines in asthma. Ann N Y Acad Sci USA 1996; 796: 272-281.

53. Church MK, Levi-Schaffer F. The human mast cell. J Allergy Clin Immunol 1997; 99: 155-160.

54. Vignola AM, Campbell AM, Chanez P, Bousquet J, Paul-Lacoste P, Michel FB, Godard P. HLA-DR and ICAM-1 expression on bronchial epithelial cells in asthma and chronic bronchitis. Am Rev Respir Dis 1993; 148: 689-694.

55. Casale TB, Costa JJ, Galli SJ. TNF $\alpha$ is important in human lung allergic reactions. Am J Respir Cell Mol Biol 1996; 15: 35-44.

56. Kroegel C, Virchow J-C, Luttmann W, Walker C, Warner JA. Pulmonary immune cells in health and disease: the eosinophil leucocyte (part I). Eur Respir J 1994; 7: 519-543.

57. Clutterbuck EJ, Hirst EM, Sanderson CJ. Human interleukin-5 (IL-5) regulates the production of eosinophils in human bone marrow cultures: comparison and interaction with IL-1, IL-3, IL-6 and GM-CSF. Blood 1989; 73: 1504-1512.

58. Dahl R, Venge P, Fredens K. Eosinophils. In: Asthma. Basic mechanisms and clinical management. Academic Press, London 1992; pp 111-124.

59. Gleich GJ, Flavahan NA, Fujisawa T, Vanhoutte PM. The eosinophil as a mediator of damage to respiratory epithelium; a model for bronchial hyperreactivity. J Allergy Clin Immunol 1988; 81: 776-781.

60. Kroegel C, Warner JA, Virchow J-C, Matthys H. Pulmonary immune cells in health and disease: the eosinophil leucocyte (Part II). Eur Respir J 1994; 7: 743-760.

61. Lohmann-Matthes M-L, Steinmüller C, Franke-Ullmann G. Pulmonary macrophages. Eur Respir J 1994; 7: 1678-1689.

62. Thomas ED, Ramberg RE, Sale GE, Sparkes RS, Golde DW. Direct evidence for a bone-marrow origin of the alveolar macrophage in man. Science 1976; 192: 1016-1018.

63. Blusse van Oud Albas A, van der Linden-Schrever B, van Furth R. Origin and kinetics of pulmonary macrophages during an inflammatory reaction induced by intra-alveolar administration of aerosolized heat-killed BCG. Am Rev Respir Dis 1983; 128: 276-281.

64. Ungar J, Wilson GR. Monocytes as a source of alveolar macrophages. Am J Pathol 1985; 11 : 681-691.

65. Adamson IYR, Bowden DH. Role of monocytes and interstitial cells in the generation of alveolar macrophages. II. Kinetic studies after carbon loading. Lab Invest 1980; 54: 518-524. 
66. Joseph M, Tonnel AB, Torpier G, Capron A, Arnoux B, Benveniste J. Involvement of immunoglobulin $\mathrm{E}$ in the secretory processes of alveolar macrophages from asthmatic patients. J Clin Invest 1983; 71: 221-230.

67. Sone S, Yanagawa H, Nishioka Y, Orino E, Bhaskaran G, Nii A, Mizuno K, Heike Y, Ogushi F, Ogura T. Interleukin-4 as a potent downregulator for human alveolar macrophages capable of producing tumour necrosis factor alpha and interleukin-1. Eur Respir J 1992; 5: 174-181.

68. Chanez P, Vignola AM, Paul-Eugene N, Dugas B, Godard P, Michel FB, Bousquet J. Modulation by interleukin- 4 of cytokine release from mononuclear phagocytes in asthma. J Allergy Clin Immunol 1994; 94: 997-1005.

69. Becker S, Soukup J, Quay J. Cytokine (TNF, IL-6, IL-8) production by RSV-infected human alveolar macrophages. J Immunol 1991; 147: 4307-4312.

70. Hallsworth MP, Soh CPC, Lane SJ, Arm JP, Lee TH. Selective enhancement of GM-CSF, TNF $\alpha$, IL-1B and IL-8 production by monocytes and macrophages of asthmatic subjects. Eur Respir J 1994; 7: 1096-1102.

71. Melewicz FM, Zeiger RS, Mellon MH, O'Connor RD, Spiegelberg HL. Increased peripheral blood monocytes with $\mathrm{Fc}$ receptors for $\mathrm{IgE}$ in patients with severe allergic disorders. J Immunol 1981; 126: 1592-1595.

72. Lee TH, Lane SJ. The role of the macrophages in the mechanisms of airway inflammation in asthma. Am Rev Respir Dis 1992; 145: S27-30.

73. Gosset Ph, Tsicopoulos A, Wallaert B, Vannimenus C, Joseph M, Tonnel A-B, Capron A. Increased secretion of tumor necrosis factor $\alpha$ and interleukin- 6 by alveolar macrophages consecutive to the development of the late asthmatic reaction. J Allergy Clin Immunol 1991; 88: 561-571.

74. Viksman MY, Liu MC, Bickel CA, Schleimer RP, Bochner BS. Phenotypic analysis of alveolar macrophages and monocytes in allergic airway inflammation. Am J Respir Crit Care Med 1997; 155: 858-863.

75. Gosset PH, Laselle P, Tonnel A, Dessaint JP, Wallaert B, Prin L, Pestel J, Capron A. Production of an interleukin-1 inhibitory factor by human alveolar macrophages from normals and allergic asthmatic patients. Am Rev Respir Dis 1988; 138: 40-46.

76. Poulter LW, Janossy G, Power C, Sreenan S, Burke C. Immunological/physiological relationships in asthma: potential regulation by lung macrophages. Immunology Today 1994; 15 : 258-261.

77. Kay AB, Diaz P, Carmichael J, Grant IW. Corticosteroid-resistant chronic asthma and monocyte complement receptors. Clin Exp Immunol 1981; 44: 576-580.

78. Caroll MP, Durham SR, Walsh G, Holgate ST. Activation of neutrophils and monocytes after allergen- and histamine-induced bronchoconstriction. I Allergy Clin Immunol 1985; 75: 290-296.

79. Durham SR, Carroll M, Walsh GM, Kay AB. Leucocyte activation in allergen-induced late-phase asthmatic reaction. New Eng/ J Med 1984; 311: 1398-1402.

80. Siracusa A, Vecchiarelli A, Brugnami G, Marabinni A, Felicioni D, Severini C. Changes in interleukin-1 and tumor necrosis factor production by peripheral blood monocytes after specific bronchoprovocation test in occupational asthma. Am Rev Respir Dis 1992; 146: 408-412.

81. Vachier I, Damon M, Doucen Le C, Crastes de Paulet A, Chanez P, Michel FB, Godard Ph. Increased oxygen species generation in blood monocytes of asthmatic patients. Am Rev Respir Dis 1992; 146: 1161-1166.

82. Vachier I, Chanez P, Doucen Le C, Damon, Descomps B, Godard P. Enhancement of reactive oxygen species formation in stable and unstable asthmatic patients. Eur Respir J 1994; 7; 1585-1592.

83. Cluzel M, Damon M, Chanez P, Bousquet J, Crastes de Paulet C, Michel FB, Godard Ph. Enhanced alveolar cell luminol-dependent chemiluminescence in asthma. J Allergy Clin Immunol 1987; 80: 195-201. 
84. Barnes PJ. Reactive oxygen species and airway inflammation. Free Radic Biol Med 1990; 9: 235-243.

85. Redington AE, Howarth PH. Airway remodelling in asthma. Thorax 1997; 52: 310-312.

86. Corrigan CJ. Immunological aspects of asthma. Implications for future treatment. Clin Immunother 1994; $1: 31-42$.

87. Aas K. Heterogeneity of bronchial asthma. Sub-populations -or different stages of the disease. Allergy 1981; 36: 3-14.

88. Godard Ph, Clark TJH, Busse WW, Woolcock AJ, Sterk P, Aubier M, Pride N, Postma D. Clinical assessment of patients. Eur Respir J 1998; 11 (suppl 26):2s-5s.

89. Djukanovic R, Wilson JW, Britten YM, Wilson SJ, Walls AF, Poche WF, Howarth PH, Holgate ST. Effect of an inhaled corticosteroid on airway inflammation and symptoms of asthma. Am Rev Respir Dis 1992; 145: 669-674.

90. Burke C, Power CK, Norris A, Condez A, Schmekel B, Poulter LW. Lung function and immunopathological changes after inhaled corticosteroid therapy in asthma. Eur Respir J 1992; 5: 73-79.

91. Jeffery PK, Godfrey RW, Ådelroth E, Nelson F, Rogers A, Johansson S-A. Effects of treatment on airway inflammation and thickening of basement membrane reticular collagen in asthma. Am Rev Respir Dis 1992; 145: 890-899.

92. Wang JH, Trigg CJ, Jagdish LD, Jordan S, Davies RJ. Effect of inhaled beclomethasone dipropionate on expression of proinflammatory cytokines and activated eosinophils in the bronchial epithelium of patients with mild asthma. J Allergy Clin Immunol 1994; 94: 1025-1034.

93. Trigg CJ, Manolitsas ND, Wang J, Calderon MA, McAulay A, Jordan SE, Herdman MJ, Jhalli N, Duddle JM, Hamilton SA, Devalia JL, Davies RJ. Placebo-controlled immunopathological study of four months of inhaled corticosteroids in asthma. Am J Respir Crit Care Med 1994; 150: $17-22$.

94. Bentley AM, Hamid Q, Robinson DS, Schotman E, Meng Q, Assoufi B, Kay AB, Durham SR.Prednisolone treatment in asthma. Reduction in the numbers of eosinophils, T cells, tryptase-only positive mast cells, and modulation of IL-4, IL-5, and interferon-gamma cytokine gene expression within the bronchial mucosa. Am J Respir Crit Care Med 1996; 153: 551-556.

95. Sont JK, Van Krieken JHJM, Evertse CE, Hooijer R, Willems LNA, Sterk PJ. Relationship between the inflammatory infiltrate in bronchial biopsy specimens and clinical severity of asthma in patients treated with inhaled steroids. Thorax 1996; 51: 496-502.

96. Klech $\mathrm{H}$, Pohl W. Technical recommendations and guidelines for bronchoalveolar lavage (BAL).Report of the S.E.P. Task group on BAL. Eur Respir J 1989; 2: 561-585.

97. Woolley KL, Adelroth E, Woolley MJ, Ellis R, Jordana M, O'Byrne PM. Granulocyte-macrophage colony-stimulating factor, eosinophils and eosinophil cationic protein in subjects with and without mild, stable, atopic asthma. Eur Respir J 1994; 7:1576-1584.

98. Graham DR, Luksza AR, Evans CC. Bronchoalveolar lavage in asthma. Thorax 1985; 40: 717.

99. Wardlaw AJ, Dunnette S, Gleich GJ, Collins JV, Kay AB. Eosinophils and mast cells in bronchoalveolar lavage in subjects with mild asthma. Relationship to bronchial hyperreactivity. Am Rev Respir Dis 1988; 137: 62-69.

100. Walker C, Bode E, Boer L, Hansel TT, Blaser K, Virchow J-C. Allergic and non-allergic asthmatics have distinct patterns of T-cell activation and cytokine-production in peripheral blood and bronchoalveolar lavage. Am Rev Respir Dis 1992; 146: 109-115.

101. Wilson JW, Djukanovic R, Howarth PH, Holgate ST. Lymphocyte activation in bronchoalveolar lavage and peripheral blood in atopic asthma. Am Rev Respir Dis 1992; 145: 958-960.

102. Park CS, Lee SM, Chung SW, Uh S, Kim HT, Kim YH. Interleukin-2 and soluble interleukin-2 receptor in bronchoalveolar lavage fluid from patients with bronchial asthma. Chest 1994; 106: 400-406. 
103. Virchow JC, Walker C, Hafner D, Kortsik C, Werner P, Matthys H, Kroegel C. T-cells and cytokines in broncho-alveolar lavage fluid after segmental allergen provocation in atopic asthma. Am J Respir Crit Care Med 1995; 151: 960-968.

104. Gosset P, Tsicopoulos A, Wallaert B, Joseph M, Capron A, Tonnel AB. Tumor necrosis factor alpha and interleukin- 6 production by human mononuclear phagocytes from allergic asthmatics after lgE-dependent stimulation. Am Rev Respir Dis 1992; 146: 768-774.

105. Gratziou C, Caroll M, Montefort S, Teran L, Howarth PH, Holgate ST. Inflammatory and T-cell profile of asthmatic airways 6 hours after local allergen provocation. Am J Respir Crit Care Med 1996; 153: 515-520.

106. Takahashi N, Liu MC, Proud D, Yu XY, Hasegawa S, Spannhake EW. Soluble intercellular adhesion molecule 1 in bronchoalveolar lavage fluid of allergic subjects following segmental antigen challenge. Am J Respir Crit Care Med 1994; 150: 704-709.

107. Duddridge M, Ward C, Hendrick DJ, Walters EH. Changes in bronchoalveolar lavage inflammatory cells in asthmatic patients treated with high dose inhaled beclomethasone dipropionate. Eur Respir J 1993; 6: 489-497.

108. Ädelroth E, Rosenhall L, Johansson S-A, Linden M, Venge P. Inflammatory cells and eosinophilic activity in asthmatics investigated by bronchoalveolar lavage. The effects of antiasthmatic treatment with budenoside or terbutaline. Am Rev Respir Dis 1990; 142: 91-99.

109. Wilson JW, Djukanovic R, Howarth PH, Holgate ST. Inhaled beclomethasone dipropionate downregulates airway lymphocyte activation in atopic asthma. Am J Respir Crit Care Med 1994; 149: 86-90.

110. Robinson DS, Hamid Q, Ying S, Bentley AM, Assoufi B, Durham SR, Kay AB. Prednisolone treatment in asthma is associated with modulation of bronchoalveolar lavage cell interleukin-4, interleukin-5 and interferon-gamma gene expression. Am Rev Respir Dis 1993; 148 : 401-406.

111. Maestrelli P, Saetta M, Distefano A, Calcagni PG, Turato G, Ruggieri MP, Roggeri A, Mapp CE, Fabbri LM. Comparison of leucocyte counts in sputum, bronchial biopsies and bronchoalveolar lavage. Am J Respir Crit Care Med 1995; 152: 1926-1931.

112. Grootendorst DC, Sont JK, Willems LNA, Kluin-Nelemans JC, Van Krieken JH, Veselic-Charvat $\mathrm{M}$, Sterk PJ. Comparison of inflammatory cell counts in asthma: induced sputum versus bronchoalveolar lavage and bronchial biopsies. Clin Exp allergy 1997; 769-779.

113. Kips JC, Fahy JV, Hargreave FE, Ind PW, in 't Veen JCCM. Methods for sputum induction and analysis of induced sputum: a method for assessing airway inflammation in asthma. Eur Respir J 1998; 11 (suppl 26): 9s-12s.

114. Pin I, Gibson PG, Kolendowicz R, Girgis-Gabardo A, Denburg JA, Hargreave FE, Dolovich J. Use of induced sputum cell counts to investigate airway inflammation in asthma. Thorax 1992; 47: 25-29.

115. Pizzichini E, Pizzichini MMM, Efthiamidis A, Evans S, Morris MM, Squillace D, Gleich GJ, Dolovich J, Hargreave FE. Indices of airway inflammation in induced sputum : reproducibility and validity of cell and fluid phase measurements. Am J Respir Crit Care Med 1996; 154: 308-317.

116. Pavord ID, Pizzichini MMM, Pizzichini E, Hargreave FE. The use of induced sputum to investigate airway inflammation. Thorax 1997; 52: 498-501.

117. Hansel TT, Braunstein JB, Walker C, Blaser K, Bruijnzeel, Virchow J-C, Virchow C. Sputum eosinophils from asthmatics express ICAM-1 and HLA-DR. Clin Exp Immunol 1991; 86: 271-277.

118. Louis R, Shute J, Biagi S, Stanciu L, Marelli F, Tenor H, Hidi R, Djukanovic R. Cell infiltration, ICAM-1 expression, and eosinophil chemotactic activity in asthmatic sputum. Am J Respir Crit Care Med 1997; 155: 466-472.

119. Virchow J, Holscher U, Virchow C. Sputum ECP levels correlate with parameters of airflow obstruction. Am Rev Resp Dis 1992; 146: 604-606. 
120. Fahy JV, Liu J, Wong H, Boushey HA. Cellular and biochemical analysis of induced sputum from asthmatic and from healthy subjects. Am Rev Respir Dis 1993; 147: 1126-1131.

121. Keatings VM, Jatakon A, Worsdell YM, Barnes PJ. Effect of inhaled and oral glucocorticoids on inflammatory indices in asthma and COPD. Am J Respir Crit Care Med 1997; 155: 542-548.

122. Keatings VM, Barnes PJ. Granulocyte activation markers in induced sputum: comparison between chronic obstructive pulmonary disease, asthma and normal subjects. Am J Respir Crit Care Med 1997; 155: 449-453.

123. Gelder CM, Thomas PS, Yates DH, Adcock IM, Morrison JFJ, Barnes PJ. Cytokine expression in normal, atopic, and asthmatic subjects using the combination of sputum induction and the polymerase chain reaction. Thorax 1995; 50: 1033-1037.

124. Keatings VM, O'Connor BJ, Wright LG, Huston DP, Corrigan CJ, Barnes PJ. Late response to allergen is associated with increased concentrations of tumor necrosis factor- $\alpha$ and IL- 5 in induced sputum. J Allergy Clin Immunol 1997; 99: 693-698.

125. Keatings VM, Evans DJ, O'Connor BJ, Barnes PJ. Cellular profiles in asthmatic airways: a comparison of induced sputum bronchial washing, and bronchoalveolar lavage fluid. Thorax 1997; 52: 372-374.

126. Pizzichini E, Pizzichini MMM, Kidney JC, Eftiamidis A, Hissack P, Popov T, Cox G, Dolovich J, O'Byrne P, Hargreave FE. Induced sputum, bronchoalveolar lavage and blood from mild asthmatics; inflammatory cells, lymphocyte subsets and soluble markers compared. Eur Respir J 1998; 11: 828-834.

127. Fahy JV, Wong H, Liu J, Boushey HA. Comparison of samples collected by sputum induction and bronchoscopy from asthmatic and healthy subjects. Am J Respir Crit Care Med 1995; 152: 53-58.

128. Pin I, Freitag AP, O'Byrne PM, Girgis-Gabardo A, Watson RM, Dolovich J, Denburg JA, Hargreave $\mathrm{FE}$. Changes in the cellular profile of induced sputum after allergen-induced asthmatic responses. Am Rev Respir Dis 1992; 145: 1265-1269.

129. Fahy JV, Liu J, Wong H, Boushey HA. Analysis of cellular and biochemical constituents of induced sputum after allergen challenge: a method for studying allergic airway inflammation. J Allergy Clin Immunol 1994; 93: 1031-1039.

130. Claman DM, Boushey HA, Liu J, Wong H, Fahy JV. Analysis of induced sputum to examine the effects of prednisone on airway inflammation in asthmatic subjects. J Allergy Clin Immunol 1994; 94: 861-869.

131. Holz O, Richter K, Jörres RA, Speckin P, Mücke M, Magnussen H. Changes in sputum composition between two inductions performed on censecutive days. Thorax 1998; 53: 83-86.

132. Nightingale JA, Rogers DF, Barnes PJ. Effect of repeated sputum induction on cell counts in normal volunteers. Thorax 1998; 53: 87-90.

133. Barnes PJ, Liew FY. Nitric oxide and inflammation. Immunology Today 1995; 16: 128-130.

134. Gustafsson LE. Exhaled nitric oxide as a marker in asthma. Eur Respir J 1998; 11 (suppl 26): 49s-52s.

135. Hamid Q, Springall DR, Riveros-Moreno V, Chanez P, Howarth P, Redington A, Bousquet J, Godard P, Holgate S, Polak JM. Induction of nitric oxide synthase in asthma. Lancet 1993; 342: 1510-1513.

136. Moncada S, Palmer RMJ, Higgs EA. Nitric oxide: physiology, pathophysiology and pharmacology. Pharmacol Rev 1991; 43: 109-142.

137. Borland C, Cox Y, Higenbottam T. Measurement of exhaled nitric oxide in man. Thorax 1993; 48: 1160-1162.

138. Leone AM, Gustafsson LE, Francis PL, Persson MG, Wiklund NP, Moncada S. Nitric oxide is present in exhaled breath in humans; direct GC-MS confirmation. Biochem Biophys Res Commun 1994; 201: 883-887.

139. Alving K, Weitzberg E, Lundberg JM. Increased amount of nitric oxide in exhaled air of asthmatics. Eur Respir J 1993; 6: 1368-1370. 
140. Kharitonov SA, Yates D, Robbins RA, Logan-Sinclair R, Shinebourne E, Barnes PJ. Increased nitric oxide in exhaled air of asthmatic patients. Lancet 1994; 343: 133-135.

141. Kharitonov SA, Chung KF, Evans D, O'Connor B, Barnes PJ. Increased exhaled nitric oxide in asthma is mainly derived from the lower respiratory tract. Am J Respir Crit Care Med 1996; 153: $1773-1780$

142. Kharitonov SA, O'Connor BJ, Evans DJ, Barnes PJ. Allergen-induced late asthmatic reactions are associated with elevation of exhaled nitric oxide. Am J Respir Crit Care Med 1995; 151 : 1894-1899.

143. Taylor-Robinson AW, Liew FY, Severn A, Xu D, McSorley SJ, Garside P, Padron J, Philips RS. Regulation of the immune response by nitric oxide differentially produced by Th1 and Th2 cells. Eur J Immunology 1994; 24: 980-984.

144. Artlich A, Hagenah JU, Jonas S, Ahrens P, Gortner L. Exhaled nitric oxide in childhood asthma. Eur J Pediatr 1996; 155: 698-701.

145. Dötsch J, Demirakca S, Terbrack HG, HülsG, Rascher W, Kühl PG. Airway nitric oxide in asthmatic children and patients with cystic fibrosis. Eur Respir J 1996; 9: 2537-2540.

146. Yates DH, Kharitonov SA, Robbins RA, Thomas PS, Barnes PJ. Effect of a nitric oxide synthase inhibitor and a glucocorticosteroid on exhaled nitric oxide. Am J Respir Crit Care Med 1995; 152: 892-896.

147. Massaro AF, Gaston B, Kita D, Fanta C, Stamler JS, Drazen JM. Expired nitric oxide levels during treatment of acute asthma. Am J Respir Crit Care Med 1995; 152: 800-803.

148. Kharitonov SA, Alving K, Barnes PJ. ERS Task Force Report. Exhaled and nasal nitric oxide measurements: recommendations. Eur Respir J 1997; 10: 1683-1993.

149. Saetta M, Thiene G, Crescioli S, Fabbri LM. Fatal asthma in a young patient with severe bronchial hyperresponsiveness but stable peak flow records. Eur Respir J 1989; 2: 1008-1012.

150. Schatz M, Wasserman S, Partterson R. The eosinophil and the lung. Arch Intern Med 1982; 142: $1515-1519$.

151. Charles TJ, Williams SJ, Seaton A, Bruce C, Taylor WH. Histamines, basophils and eosinophils in severe asthma. Clin Sci 1979; 57: 39-45.

152. Horn B, Robin E, Theodore J, Van Kessel A. Total eosinophil counts in the management of bronchial asthma. N Engl J Med 1975; 292: 1152-1155.

153. Dahl R, Venge P, Olsson I. Variations of blood eosinophils and eosinophil cationic protein in serum in patients with bronchial asthma. Studies during inhalation challenge test. Allergy 1978; 33: 211-215.

154. Cookson WO, Craddock CF, Benson MK, Durham SR. Falls in peripheral eosinophil counts parallel the late asthmatic response. Am Rev Respir Dis 1989; 139: 458-462.

155. Durham SR, Kay AB. Eosinophils, bronchial hyperreactivity and late phase asthmatic reactions. Clin Allergy 1985; 15: 411-418.

156. De Monchy JGR, Kauffman HF, Venge P, Koeter GH, Janssen HM, Sluiter HJ, De Vries K. Broncho-alveolar eosinophilia during allergen-induced late asthmatic reaction. Am Rev Respir Dis 1985; 131: 373-376.

157. Rossi GA, Crimi E, Lanterno S, Gianiorio P, Oddera S, Crimi P, Brusasco V. Late phase asthmatic reaction to inhaled allergen is associated with early recruitment of eosinophils within the airways. Am Rev Respir Dis 1991; 144: 379-383.

158. Mengelers HJ, Maikoe T, Brinkman L, Hooibrink B, Lammers J-WJ, Koenderman L. Immunophenotyping of eosinophils recovered from blood and BAL of allergic asthmatics. Am J Respir Crit Care Med 1994; 149: 345-351.

159. Hodges MK, Weller PF, Gerard NP, Ackerman SJ, Drazen JM. Heterogeneity of leukotriene C4 production by eosinophils from asthmatics and from normal subjects. Am Rev Respir Dis 1988; 138: 799-804.

160. Fukuda T, Dunnette SL, Reed CE, Ackerman SJ, Peters MS, Gleich GJ. Increased numbers of hypodense eosinophils in the blood of patients with bronchial asthma. Am Rev Respir Dis 1985; 132: 981-985. 
161. Wempe JB, Tammeling EP, Koeter GH, Hakansson L, Venge P, Postma DS. Blood eosinophil numbers and activity during 24 hours: effects of treatment with budenoside and bambuterol. J Allergy Clin Immunol 1992; 90: 757-765.

162. Griffin E, Hakansson L, Formgren H, Jorgenson K, Peterson C, Venge P. Blood eosinophil number and activity in relation to lung function in patients with asthma and with eosinophilia. J Allergy Clin Immunol 1991; 87: 548-557.

163. Evans PM, O'Connor BJ, Fuller RW, Barnes PJ, Chung KF. Effect of inhaled corticosteroids on peripheral blood eosinophil counts and density profiles in asthma. I Allergy Clin Immunol 1993; 91: 643-650.

164. Durham SR, Loegering DA, Dunnette S, Gleich GJ, Kay AB. Blood eosinophils and eosinophil-derived proteins in allergic asthma. J Allergy Clin Immunol 1989; 84: 931-936.

165. Venge P. Eosinophil activity in bronchial asthma. Allergy Proc 1994; 15: 139-141.

166. Motojima S, Tateishi K, Koseki T, Makino S, Fukuda T. Serum levels of eosinophil cationic protein and IL-5 in patients with asthma without systemic corticosteroids. Int Arch Allergy Immunol 1997; 114(suppl 1): 55-59.

167. Ronchi MC, Piragino C, Rosi E, Stendardi L, Tanini A, Galli G, Duranti R, Scano G. Do sputum eosinophils and ECP relate to the severity of asthma? Eur Respir J 1997; 10: 1809-1813.

168. Bancalari L, Dente FL, Cianchetti S, Prontera C, Taccola M, Bacci E, Carletti A, Di Franco A, Giannini D, Vagaggini B, Ferdeghini M, Paggiaro PL. Blood markers of early and late airway responses to allergen in asthmatic subjects. Relationship with functional findings. Allergy 1997; 52: $32-40$.

169. Vatrella A, Ponticiello A, Parrella R, Romano L, Zofra S, DiLeva A, Bariffi F. Serum eosinophil cationic protein (ECP) as a marker of disease activity and treatment efficacy in seasonal asthma. Allergy 1996; 51: 547-555.

170. Niggeman P, Ertel M, Lanner A, Wahn U. Relevance of serum ECP measurements for monitoring acute asthma in children. J Asthma 1996; 33: 327-330.

171. Hoshino M, Nakamura Y. Relationship between activated eosinophils of the bronchial mucosa and serum eosinophil cationic protein in asthma. Int Arch Allergy Immunol 1997; 112: 59-64.

172. Kristjansson S, Strannegard IL, Wennergren G. Inflammatory markers in childhood asthma. Ann Med 1996; 28: 395-399.

173. Hoekstra MO, Hovenga H, Gerritsen J, Kauffman HF. Eosinophils and eosinophil-derived proteins in children with moderate asthma. Eur Respir J 1996; 9: 2231-2235.

174. Grigg J, Venge P. Inflammatory markers of outcome. Eur Respir J 1996; 21 (suppl): 16s-21s.

175. Lanz MJ, Leung DY, McCormick DR, Harbeck R, Szefler SJ, White CW. Comparison of exhaled nitric oxide, serum eosinophilic cationic protein, and soluble interleukin-2 receptor in exacerbations of pediatric asthma. Pediatr Pulmonol 1997; 24: 305-311.

176. Robinson DS, Assoufi B, Durham SR, Kay AB. Eosinophilic cationic protein (ECP) and eosinophil protein $X(E P X)$ concentrations in serum and bronchial lavage fluid in asthma. Effect of prednisolone treatment. Clin Exp Allergy 1995; 25: 1118-1127.

177. Sorva R, Metso T, Turpeinen M, Juntunen-Backman K, Bjorksten F, Haahtela T. Eosinophil cationic protein in induced sputum as a marker of inflammation in asthmatic children. Pediatr Allergy Immunol 1997; 8: 45-50.

178. Wever AM, Wever-Hess J, Hermans J. The use of serum eosinophil cationic protein (ECP) in the management of steroid therapy in chronic asthma. Clin Exp Allergy 1997; 27: 519-529.

179. Carlsen KH, Halvorsen R, Pettersen M, Carlsen KC. Inflammation markers and symptom activity in children with bronchial asthma. Influence of atopy and eczema. Pediatr Allergy Immunol 1997; 8: 112-120.

180. Ferguson AC, Vaughan R, Brown H, Curtis C. Evaluation of serum eosinophilic cationic protein as a marker of disease activity in chronic asthma. J Allergy Clin Immunol 1995; 95: 23-28. 
181. Oymar K, Elsayed S, Bjerknes R. Serum eosinophil cationic protein and interleukin-5 in children with bronchial asthma and acute bronchiolitis. Pediatr Allergy Immunol 1996; 7 : 180-186.

182. Tischendorf FW, Brattig NW, Buttner DW, Pieper A, Lintzel M. Serum levels of eosinophil cationic protein, eosinophil-derived neurotoxin and myeloperoxidase in infections with filariae and schistosomes. Acta Trop 1996; 62: 171-182.

183. Wever AMJ, Wever-Hess J, Hensgens HESJ, Hermans J. Serum eosinophil cationic protein $(\mathrm{ECP})$ in chronic asthma. Relationship to spirometry, flow-volume curves, $\mathrm{PC}_{20}$, and exacerbations. Resp Med 1994; 88: 613-621.

184. Corrigan CJ, Hartnell A, Kay AB. T lymphocyte activation in acute severe asthma. Lancet 1988; 1(8595): 1129-1132

185. Virchow JC, Oehling A, Boer L, Hansel TT, Werner P, Matthys P, Blaser K, Walker C. Pulmonary function, activated T-cells, peripheral blood eosinophilia, and serum activity for eosinophil survival in vitro: a longitudinal study in bronchial asthma. I Allergy Clin Immunol 1994; 94: 240-249.

186. Walker C, Kaegi MK, Braun P, Blaser K. Activated T cells and eosinophilia in bronchoalveolar lavages from subjects with asthma correlated with disease activity. I Allergy Clin Immunol 1991; 88: 935-942.

187. Corrigan CJ, Kay AB. T cells and eosinophils in the pathogenesis of asthma. Immunology Today 1992, 13: 501-506.

188. Brown PH, Crompton GK, Greening AP. Proinflammatory cytokines in acute asthma. Lancet 1991; 338; 590-593.

189. Corrigan CJ, Brown PH, Barnes NC, Tsai JJ, Frew AJ, Kay AB. Glucocorticoid resistance in chronic asthma. Peripheral blood T-lymphocyte activation and comparison of the T-lymphocyte inhibitory effects of glucocorticoids and cyclosporin A. Am Rev Respir Dis 1991; 144: 1026-1032.

190. Corrigan CJ, Kay AB. T-lymphocyte activation in acute severe asthma. Relationship to disease severity and atopic status. Am Rev Respir Dis 1990; 141: 970-977.

191. Motojima S, Hirata A, Kushima A, Tateishi K, Numao T, Fukuda T, Makino S. Serum levels of soluble interleukin-2 receptor in asthma patients. J Asthma 1995; 32: 151-158.

192. Matsumoto K, Taki F, Miura M, Matsuzaki M, Takagi K. Serum levels of soluble IL-2R, IL-4 and soluble Fc epsilon RII in adult bronchial asthma. Chest 1994; 105: 681-686.

193. Nabetani M, Yamasaki T, Kameda A, Okamoto O, Kishimoto T. Interleukin-2 receptor positive T and B cells in children with acute severe asthmatic attack. Acta Paediatr Jpn 1995; 37: 474-478.

194. Alexander AG, Barnes NC, Kay AB, Corrigan CJ. Clinical response to cyclosporin in chronic severe asthma is associated with reduction in serum soluble interleukin-2 receptor concentrations. Eur Respir J 1995; 8: 574-578.

195. Lewandowicz-Uszynska A, Jankowski A, Korobczak I, Matusiewicz K, Stasiewicz U, Polanska G. Level of GM-CSF and IL-4 in serum of children with bronchial asthma. Pneumol Alergol Pol 1996, 64: 450-455.

196. Daher S, Santos LM, Sole D, De Lima MG, Naspitz CK, Musatti CC. Interleukin-4 and soluble CD23 serum levels in asthmatic atopic children. J Invest Allergol Clin Immunol 1995; 5: 251-254.

197. Tang ML, Coleman J, Kemp AS. Interleukin-4 and interferon-gamma production in atopic and non-atopic children. Clin Exp Allergy 1995; 25: 515-521.

198. Turktas I, Demirsoy S, Koc E, Gokcora N, Elbeg S. Effects of inhaled steroid treatment on serum eosinophilic cationic protein (ECP) and low affinity receptor for IgE (Fc epsilon RII/sCD23) in childhood bronchial asthma. Arch Dis Child 1996; 75: 314-318.

199. Ohshima Y, Katamura K, Miura M, Mikawa H, Mayumi M. Serum levels of interleukin-4 and soluble CD23 in children with allergic disorders. Eur J Pediatr 1995; 154: 723-728. 
200. Shi HZ, Xiao CQ, Zhong D, Qin SM, Liu Y, Liang GR, Xu H, Chen YQ, Long XM, Xie ZF. Effect of inhaled interleukin-5 on airway hyperreactivity and eosinophilia in asthmatics. Am J Respir Crit Care Med 1998; 157: 204-209.

201. Alexander AG, Barkans J, Moqbel R, Barnes NC, Kay AB, Corrigan CJ. Serum interleukin 5 concentrations in atopic and non-atopic patients with glucocorticoid-dependent chronic severe asthma. Thorax 1994; 49: 1231-1233.

202. Corrigan CJ, Haczku A, Gemou-Engesaeth V, Doi S, Kikuchi Y, Takatsu K, Durham SR. CD4 T-lymphocyte activation in asthma is accompanied by increased serum concentrations of interleukin-5. Am Rev Respir Dis 1993; 147: 540-547.

203. Tang ML, Coleman J, Kemp AS. Interleukin-4 and interferon-gamma production in atopic and non-atopic children with asthma. Clin Exp Allergy 1995; 25: 512-521.

204. Nurse B, Haus M, Puterman AS, Weinberg EG, Potter PC. Reduced interferon-gamma but normal IL- 4 and IL-5 release by peripheral blood mononuclear cells from Xsosa children with atopic asthma. J Allergy Clin Immunol 1997; 100: 662-668.

205. Hashimoto S, Amemiya E, Tomita Y, Kobatashi T, Arai K, Yamaguchi M, Horie T. Elevation of soluble IL-2 receptor and IL-4, and non-elevation of IFN-gamma in sera from patients with allergic asthma. Ann Allergy 1993; 71: 455-458.

206. Beutler B, Cerami A. The biology of cachectin/TNF-a primary mediator of the host response. Ann Rev Immunol 1989; 7: 625-655.

207. Broide DH, Lotz M, Cuomo AJ, Coburn DA, Federman EC, Wasserman SI. Cytokines in symptomatic asthma airways. J Allergy Clin Immunol 1992; 89: 958-967.

208. Ackerman V, Marini M, Vittori E, Bellini A, Vassali G, Mattoli S. Detection of cytokines and their cell sources in bronchial biopy specimens from asthmatic patients. Relationship to atopic status, symptoms, and level of airway hyperresponsiveness. Chest 1994; 105: 687-696.

209. Maestrelli P, Di Stefano A, Occari P, Turato G, Milani G, Pivirotto F, Mapp CE, Fabbri LM, Saetta M. Cytokines in the airway mucosa of subjects with asthma induced by toluene diisocyanate. Am J Respir Crit Care Med 1995; 151: 607-612.

210. Kips JC, Tavernier JH, Joos GF, Peleman RA, Pauwels RA. The potential role of tumour necrosis factor $\alpha$ in asthma. Clin Exp Allergy 1993; 23: 247-250.

211. Thomas WS, Yates DH, Barnes PJ. Tumor necrosis factor- $\alpha$ increases airway responsiveness and sputum neutrophilia in normal human subjects. Am J Respir Crit Care Med 1995; 152: 76-80.

212. Shelhamer JH, Levine SJ, Wu T, Jacoby DB, Kaliner MA, Rennard SI. Airway inflammation. Ann Intern Med 1995; 123: 288-304.

213. Koizumi A, Hashimoto S, Kobayashi T, Imai K, Yachi A, Horie T. Elevation of serum soluble vascular cell adhesion molecule-1 (sVCAM-1) levels in bronchial asthma. Clin Exp Immunol 1995; 101: 468-473.

214. Kobayashi T, Hashimoto S, Imai K, Amemiya E, Yamaguchi M, Yachi A, Horie T. Elevation of serum soluble intercellular adhesion molecule-1 (sICAM-1) and SE-selectin levels in bronchial asthma. Clin Exp Immunol 1994; 96: 110-115.

215. Michie HR, Manogue KR, Spriggs DR, Revhaug A, O’Dwyer S, Dinarello CA, Cerami A, Wolff SM, Wilmore DW. Detection of circulating tumor necrosis factor after endotoxin administration. N Engl J Med 1988; 318: 1481-1486.

216. Yokoyama A, Kohno N, Fujino S, Hamada H, Inoue Y, Fujioka S, Ishida S, Hiwada K. Circulating IL-6 levels in patients with bronchial asthma. Am J Respir Crit Care Med 1995; 151:1354-1358.

217. Yokoyama A, Kohno N, Sakai K, Kondo K, Hirasawa Y, Hiwada K. Circulating levels of soluble Interleukin-6 receptor in patients with bronchial asthma. Am J Respir Crit Care Med 1997; 156: 1688-1691.

218. Wang JH, Trigg CJ, Devalia JL, Jordan S, Davies RJ. Effect of inhaled beclomethasone dipropionate on expression of proinflammatory cytokines and activated eosinophils in the bronchial epithelium of patients with mild asthma. J Allergy Clin Immunol 1994; 94: 1025-1034. 
219. Leeuwenberg JFM, Jeunhomme TMAA, Buurman WA. Slow release of soluble TNF receptors by monocytes in vitro. J Immunol 1994; 152: 4036-4043.

220. Aderka D, Engelmann H, Shemer-Avni Y, Hornik V, Galil A, Sarov B, Wallach D. Variation in serum levels of the soluble TNF-receptors among healthy individuals. Lymphokine Cytokine Res 1992; 11: 157-159.

221. Mackay F, Loetscher H, Stueber D, Gehr G, Lesslauer W. Tumor necrosis factor $\alpha(T N F \alpha)$ induced cell adhesion to human endothelial cells is under dominant control of one receptor type, TNF-R55. J Exp Med 1993; 177: 1277-1286.

222. Beutler B, van Huffel C. Unraveling function in the TNF ligand and receptor families. Science $1994 ; 264: 667-668$.

223. Medvedev AE, Espevik T, Ranges G, Sundan A. Distinct roles of the two tumor necrosis factor (TNF) receptors in modulating TNF and lymphotoxin- $\alpha$ effects. J Biol Chem 1996; 271: 9778-9784.

224. Yoshida S, Hashimoto S, Nakayama T, Kobayashi T, Koizumi A, Horie T. Elevation of serum soluble tumour necrosis factor (TNF) receptor and IL-1 receptor antagonist levels in bronchial asthma. Clin Exp Immunol 1996; 106: 73-78.

225. Laan MP, Koning H, Baert MR, Oranje AP, Buurman WA, Savelkoul HF, Neijens HJ. Levels of soluble intercellular adhesion molecule-1, soluble E-selectin, tumor necrosis factor-alpha, and soluble tumor necrosis factor receptor p55 and p75 in atopic children. Allergy 1998; 53: 51-58.

226. Studnicka-Benke A, Steiner G, Petera P, Smolen JS. Tumour necrosis factor alpha and its soluble receptors parallel clinical disease and autoimmune activity in systemic lupus erythematosus. $B r J$ Rheumatol 1996; 35: 1067-1074.

227. Rieckmann P, Martin S, Weichselbraun I, Albrecht M, Kitze B, Weber T, Tumani H, Broocks A, Lüer W, Helwig A, Poser S. Serial analysis of circulating adhesion molecules and TNF receptor in serum from patients with multiple sclerosis: CICAM-1 is an indicator for relapse. Neurology 1994; 44: 2367-2372.

228. Wenisch C, Varijanonta S, Looareesuwan S, Graninger W, Pichler R, Wernsdorfer W. Soluble intercellular adhesion molecule-1 (ICAM-1), Endothelial leucocyte adhesion molecule-1 (ELAM-1), and tumor necrosis factor receptor ( $55 \mathrm{kDa}$ TNF-R) in patients with acute Plasmodium Falciparum malaria. Clin Immunol Immunopathol 1994; 71: 344-348.

229. Viac J, Vincent C, Palacio S, Schmitt D, Claudy A. Tumour necrosis factor(TNF) soluble receptors in malignant melanoma: correlation with soluble ICAM-1 levels. Eur J Cancer 1996; 32A: 447-449.

230. Gearing AJ, Newman W. Circulating adhesion molecules in disease. Immunology Today $1993 ; 14 ; 506-512$.

231. Hogg N, Berlin C. Structure and function of adhesion receptors in leucocyte trafficking. Immunology Today 1995; 16: 327-330.

232. Wegner CD, Gundel RH, Reilly P, Haynes N, Letts LG, Rothlein R. Intercellular adhesion molecule-1 (ICAM-1) in the pathogenesis of asthma. Science 1990; 247: 456-459.

233. Gosset Ph, Tillie-Leblond I, Janin A, Marquette C-H, Copin M-C, Wallaert B, Tonnel A-B. Expression of E-selectin, ICAM-1 and VCAM-1 on bronchial biopsies from allergic and non-allergic asthmatic patients. Int Arch Allergy Immunol 1995; 106: 69-77.

234. Montefort S, Roche WR, Howarth PH, Djukanovic R, Gratziou C, Caroll M, Smith L, Britten KM, Haskard D, Lee TH, Holgate TH. Intercellular adhesion molecule -1(ICAM-1) and endothelial leucocyte adhesion molecule-1 (ELAM-1) expression in the bronchial mucosa of normal and asthmatic subjects. Eur Respir J 1992; 5: 815-823.

235. Montefort S, Holgate ST, Howarth PH. Leucocyte-endothelial adhesion molecules and their role in bronchial asthma and allergic rhinitis. Eur Respir J 1993; 6: 1044-1054.

236. Lee YC, Cheon KT, Rhee YK. Changes of soluble ICAM-1 levels in serum and bronchoalveolar lavage fluid from patients with atopic bronchial asthma after allergen challenge. I Asthma 1997; 34: 405-412. 
237. Gonokami Y, Konno S, Kurokawa M, Kawazu K, Ueno K, Tomita K, Ike M, Nyui M, Adachi M. Circulating intercellular adhesion molecule-1 concentrations following bronchial provocation in atopic asthma. Int Arch Allergy Immunol 1997; 112: 386-391.

238. Montefort S, Lai CKW, Kapai P, Leung J, Lai KN, Chan HS, Haskard DO, Howarth PH, Holgate ST. Circulating adhesion molecules in asthma. Am J Respir Crit Care Med 1994; 149: 1149-1152.

239. Shioto Y, Wilson JG, Marukawa M, Ono T, Kaji M. Soluble intercellular adhesion molecule 1 (ICAM-1) antigen in sera of bronchial asthmatics. Chest 1996; 109: 94-99.

240. Riise GC, Larsson S, Lowhagen O, Andersson BA. Circulating leucocyte adhesion molecules in stable asthma and nonobstructive chronic bronchitis. Allergy 1995; 50: 693-698.

241. Yamashita N, Kaneko S, Kouro O, Yamamoto S, Sakane T. Soluble E-selectin as a marker of disease activity in atopic dermatitis. J Allergy Clin Immunol 1997; 99: 410-416.

242. Chanez P, Dent G, Yukawa T, Barnes PJ, Chung KF. Generation of oxygen free radicals from blood eosinophils from asthma patients after stimulation with PAF or phorbol esther. Eur Respir J 1990; 3: 1002-1007.

243. Sedgwick JB,Geiger KM, Busse WW. Superoxide generation by hypodense eosinophils from patients with asthma. Am Rev Respir Dis 1990; 142: 120-125.

244. Jarjour NN, Calhoun WJ. Enhanced production of oxygen radicals in asthma. J Lab Clin Med 1994; 123: 131-137.

245. Kelly C, Ward C, Stenton CS, Bird G, Hendrick DJ, Walters EH. Number and activity of inflammatory cells in broncho-alveolar lavage fluid in asthma and their relation to airway responsiveness. Thorax 1988; 43: 684-692.

246. Calhoun WJ, Bush RK. Enhanced reactive oxygen species metabolism of airspace cells and airway inflammation follow antigen challenge in human asthma. J Allergy Clin Immunol 1990; 86: 306-313.

247. Sanders SP, Zweier JL, Harrison J, Trush MA, Rembish SJ, Liu MC. Spontaneous oxygen radical production at sites of antigen challenge in allergic subjects. Am J Respir Crit Care Med 1995; 151: 1725-1733.

248. Nordman SAS, Nyberg PW. Whole blood chemiluminescence as a systemic inflammatory parameter in asthma. J Allergy Clin Immunol 1994; 94: 853-860.

249. Antczak A, Nowak D, Shariati B, Król M, Piasecka G, Kurmanowska Z. Increased hydrogen peroxide and thiobarbituric-acid reactive products in expired breath condensate of asthmatic patients. Eur Respir J 1997; 10: 1235-1241.

250. Jöbsis Q, Raatgreep HC, Hermans PWM, de Jongste JC. Hydrogen peroxide in exhaled air is increased in stable asthmatic children. Eur Respir J 1997; 10: 519-521.

251. Dahlén SE, Kumlin M. Can asthma be studied in urine?. Clin Exp Allergy 1998; 28: 1298-133.

252. Smith CM, Christie PE, Hawksworth RJ, Thien F, Lee TH. Urinary leukotriene $E_{4}$ levels after allergen and exercise challenge in bronchial asthma. Am Rev Respir Dis 1991; 144: 1411-1413.

253. Grootendorst DC, Dahlen SE, O'Sullivan S, Kumlin M, Duiverman EJ, Romeijn JJ, Sterk PJ, Roldaan AC. Non-invasive markers of inflammation during allergen-avoidance at high altitude in adulescents with severe asthma. Am J Respir Crit Care Med 1998; 157: A858

254. Hoekstra MO, Hovenga H, Gerritsen J, Kaufman HF. Eosinophils and eosinophil-derived proteins in children with moderate asthma. Eur Respir J 1996; 9: 2231-2235.

255. Lugosi E, Halmerbauer G, Frischer T, Koller DY. Urinary eosinophil protein X in relation to disease activity in childhood asthma. Allergy 1997; 52: 584-588.

256. Nagakura T, Obata T, Schichijo K, Matsuda S, Sigimoto H, Yamashita K, Masaki T, Maekawa K. GC/MS analysis of urinary excretion of $9 \alpha, 11 B-P_{\text {GF }}$ in acute and exercise-induced asthma in children. Clin Exp Allergy 1998; 28: 181-186.

257. O'Sullivan S, Roquet A, Dahlén B, Larsen F, Eklund A, Kumlin M, O'Byrne PM, Dahlén SE. Evicence for mast cell activation during exercise-induced bronchoconstriction. Eur Respir J $1998 ; 12: 345-350$. 


\section{CHAPTER 2}

\section{Aim and design of the thesis}

The previous two decades have shown a tremendous increase in the knowledge of asthma. Cytokines were shown to be involved in the pathophysiology of asthma and several cytokines, like e.g. tumor necrosis factor $\alpha$, IL-1 to IL-6, IL-10 and GM-CSF have been implicated in the pathogenesis of asthma, although their precise role still remains to be established. Tumor necrosis factor $\alpha$ is one of the first cytokines generated in the inflammatory reaction. Ample studies have demonstrated a role of TNF $\alpha$ in the pathophysiology of asthma: an increased expression of tumor necrosis factor $\alpha$ has been observed in bronchial biopsies, BAL-fluid and induced sputum; increased levels of TNF $\alpha$ have been observed in sputum after specific allergen inhalation in asthmatic patients and $\mathrm{IgE}$-receptor activation in mast cells and macrophages resulted in an increased generation of TNF $\alpha$. In addition, inhalation of TNF $\alpha$ was shown to induce airway hyperresponsiveness in humans. Almost every cell type, involved in the asthmatic inflammation, has been shown to generate TNF $\alpha$. Therefore, TNF $\alpha$ is involved in two important characteristics of asthma: inflammation and bronchial hyperresponsiveness (BHR).

In chapter three, we investigated whether $\mathrm{TNF} \alpha$, as a pro-inflammatory cytokine, is able to induce bronchial hyperresponsiveness directly. We therefore investigated the effect of TNF $\alpha$ on the isotonic contraction of tracheal smooth muscle of guinea-pigs in vitro and additionally analysed whether secondary mediators are involved in the actions of TNF $\alpha$.

In chapters four and five, we investigated whether drugs, commonly used for their bronchodilatory effects in asthma, might also influence asthmatic inflammation. The drugs studied (theophylline (chapter four), salmeterol and salbutamol (chapter five)) all induce the generation of cAMP, which is involved in immunomodulation. In these in vitro studies, emphasis was placed on the effect of drugs on TNF $\alpha$ release in peripheral blood monocytes, as well as on adhesion molecule expression on endothelial cells, which plays an important role in leucocyte trafficking. We also evaluated the influence of these drugs on the release of IL-10, since IL-10 has anti-inflammatory effects and has been shown to inhibit TNF $\alpha$ release. We were especially interested in the effects of salmeterol, since, due to its long duration of action, anti-inflammatory effects may be amplified in vivo. Since release of cytokines is influenced by gene-transcription activity, both studies also evaluated the effect of drugs on mRNA levels in activated monocytes. 
Next, we evaluated changes in markers of asthmatic inflammation in patients with mild, stable asthma, who were treated with inhaled corticosteroids. We studied patients, who, according to the new guidelines for classification of asthma, should be classified as having intermittent asthma. Studies have demonstrated that, even in this group of patients with mild disease, airway inflammation and airway wall remodelling is present. Therefore, we simultaneously monitored the response of patients to corticosteroids with regard to airway hyperresponsiveness (chapter six) and with regard to changes in peripheral blood markers, involved in asthmatic inflammation (chapters seven and eight).

In chapter six, we used both conventional pulmonary function measurements and the forced oscillation technique to assess changes in bronchial responsiveness to inhaled cold air, because, especially in this group of mild asthmatic patients, the inspiratory manoeuvre, which precedes conventional lung function testing, may influence bronchoconstriction. Forced oscillation measurements may reflect bronchial tone more adequately, since this technique can be performed during quiet breathing.

In chapter seven, we monitored changes in levels of soluble TNF-receptors and soluble adhesion molecules (sICAM-1 and sE-selectin-1) in peripheral blood in order to assess changes in bronchial inflammation, induced by inhaled corticosteroids. Since the half-life of proinflammatory cytokines, especially of TNF $\alpha$, is very short, levels are often not detectable and can not be used as biomarkers. Several studies have demonstrated increased levels of these inflammatory markers in peripheral blood, both in unstable asthma and after allergen challenge. So far, the effect of inhaled corticosteroids on levels of these inflammatory markers in stable asthmatic patients is not known.

In chapter eight, we used erythrocyte antioxidant levels as marker of the asthmatic inflammation. Reactive oxygen species are involved in the development of bronchial hyperresponsiveness and studies have shown that erythrocyte antioxidant levels reflect long-term exposure to reactive oxygen species in chronic lung disease. In asthma, reactive oxygen generation is increased and, in addition, studies also observed decreased antioxidant defenses, leading to an oxidant-antioxidant imbalance, even in stable asthmatic patients. By monitoring changes in erythrocyte antioxidant levels, we tried to measure changes in bronchial inflammation induced by inhaled corticosteroids. 


\section{Tumor Necrosis factor- $\alpha$ induces hyperreactivity in tracheal smooth muscle of the guinea pig in vitro}

Evidence for the involvement of Platelet-activating factor.

HJ Pennings, K Kramer”, A Bast", WA Buurman “.”, EFM Wouters.

From the Department of Pulmonology, University Hospital Maastricht, Department of Pharmacochemistry", faculty of Chemistry, Vrije Universiteit, Amsterdam, The Netherlands and Department of Surgery "', Maastricht University, Maastricht, The Netherlands. 


\section{ABSTRACT}

Recent studies have implicated a role for tumor necosis factor- $\alpha$ (TNF $\alpha)$ in the development of the asthmatic reaction. In this study, we examined the influence of TNF $\alpha$ on isotonic contraction of tracheal smooth muscle of the guinea-pig in vitro in response to methacholine.

Tracheal rings were incubated with recombinant human tumor necrosis factor- $\alpha$ $(\operatorname{rhTNF} \alpha)\left(3.10^{-11} \mathrm{M}\right)$ for $30 \mathrm{~min}$, and concentration-response curves to methacholine before and after incubation with $\mathrm{rhTNF} \alpha$ were compared with the control.

The present study demonstrates that rhTNF $\alpha$ increases maximal isotonic contraction of tracheal smooth muscle to methacholine (mean \pm SEM $169.6 \pm 4.3 \%$, p $<$ $0.005)$. This effect was observed only after a thirty-minute delay between incubation and methacholine challenge testing. Experiments with $10^{-13}-10^{-10} \mathrm{M}$ rhTNF- $\alpha$ yielded similar results at all concentrations used. The effects of rhTNF $\alpha$ $\left(10^{-11} \mathrm{M}\right)$ on tracheal hyperreactivity could be completely inhibited by coincubation with dimeric rTNF-receptor-p80-construct $\left(10^{-10} \mathrm{M}\right)(\mathrm{p}<0.01)$. In order to analyse secondary mediator release, experiments using coincubation with indomethacin $\left(10^{-5} \mathrm{M}\right)$ and WEB $2086\left(10^{-6} \mathrm{M}\right)$, a specific platelet activating factor (PAF) antagonist, demonstrated that the effect of rhTNF $\alpha$ on tracheal rings was mediated by PAF, since WEB 2086 completely inhibited rhTNF $\alpha$-induced hyperreactivity $(\mathrm{p}<0.05)$.

In conclusion, this study demonstrates that rhTNF $\alpha$ induces hyperreactivity in tracheal smooth muscle in vitro, which was shown to be mediated by PAF. Our study emphasizes the role of TNF $\alpha$ in the pathophysiology of bronchial hyperresponsiveness.

\section{INTRODUCTION}

Bronchial hyperresponsiveness (BHR) is regarded as an important characteristic of asthma and correlates with the severity of the disease [1]. BHR can be induced after allergen-inhalation in allergic asthmatics, after viral respiratory tract infections, industrial chemical inhalation and endotoxin-inhalation [2]. In asthmatic patients, endotoxin (LPS) primarily induces a fall in $\mathrm{FEV}_{1}$ and secondarily an increase in BHR. However, it is not certain that LPS itself is primarily responsible for inducing BHR. Tumor necrosis factor- $\alpha$ (TNF $\alpha$ ) has been found to represent an important mediator of LPS-induced effects [3]. In animal models, TNF- $\alpha$ levels were elevated in bronchoalveolar lavage fluid after LPS-inhalation and, as was shown in a rat-model, TNF $\alpha$ inhalation induces BHR [4]. In asthmatic patients, TNF $\alpha$ levels were elevated in both BAL-fluid [5] and sputum [6] in the late asth- 
matic reaction and in both BAL and bronchial mucosa in symptomatic asthmatic patients $[7,8]$. In occupational asthma, increased expression of TNF $\alpha$ was observed in the bronchial submucosa of workers with toluene diisocyanate induced asthma [9]. Recently, TNF $\alpha$ inhalation was shown to induce BHR in healthy human volunteers, supporting a primary role for TNF $\alpha$ in the development of BHR [10].

TNF $\alpha$ can be released by various cell-types involved in the inflammatory response, like monocytes, alveolar macrophages, mast cells, neutrophils and Tlymphocytes, depending upon the stimulus used [11]. In stable asthmatics, increased release of TNF $\alpha$ was observed in alveolar macrophages, both spontaneously and after stimulation [12]. In allergic asthmatics, mast cells have been shown to be a source for TNF $\alpha$ [8] and mast- cell activation initiated by IgE-receptor crosslinking is considered to be a source for TNF $\alpha$ release [13]. Furthermore, Th2-lymphocytes play an important role in the development of asthma and produce a wide array of cytokines like Interleukin (IL)-4, IL-5, GM-CSF and TNF $\alpha$ [14]. In order to investigate whether TNF $\alpha$ affects the constrictor response of bronchial smooth muscle directly, we investigated the influence of TNF $\alpha$ on smooth muscle response to methacholine in guinea-pig tracheal strips. We additionally investigated whether secondary mediator release is involved in TNF $\alpha$-induced effects. This study demonstrates the ability of TNF $\alpha$ to induce hyperreactivity in tracheal smooth muscle of the guinea-pig in vitro and provides evidence for the involvement of platelet activating factor (PAF) in TNF $\alpha$-induced bronchial hyperresponsiveness.

\section{METHODS}

\section{Reagents}

Acetyl- $\beta$-methylcholine chloride (methacholine chloride) was obtained from Sigma Chemical Co (St. Louis, Mo, USA). Indomethacin was obtained from OPG-pharma (Utrecht, The Netherlands) and diluted in dimethyl-sulphoxide. Recombinant human TNF $\alpha$ was a gift from Knoll/BASF (Ludwigshafen, Germany). Recombinant human TNF-Receptor-p80:Fc (a soluble human TNFreceptor ( $\mathrm{p} 80$ ) linked to the Fc-portion of human IgG1) was kindly provided by Immunex (Seattle, WA, USA) [15]. WEB 2086 (3-[4-(clorphenyl)-9-methyl-6Hthieno(3,2f)(1,2,4)triazolo(4,3,a)(1,4)diazepine-2-yl]-1-[-4-morpholinyl]-1-propanone), a specific PAF-antagonist [16], was a gift from Dr. H. Heuer, Boehringer Mannheim GmbH (Mannheim, Germany). rhTNF $\alpha$, rTNFR-p80:Fc and WEB 2086 were dissolved in sterile PBS. All solutions were freshly prepared. 
Dunkin-Hartley guinea-pigs (300-400 g), (Harlan CPB. Zeist, The Netherlands) were sacrificed by cervical dislocation. Tracheas were rapidly dissected free from surrounding tissue, excised and opened in longitudinal direction opposite to the muscle layer by cutting through the cartilage. Tracheal strips (each containing one cartilage ring) were placed in a $20 \mathrm{~mL}$ organ bath containing Krebs buffer solution of $37^{\circ} \mathrm{C}$ (as described previously) [17] and continuously gassed with $95 \% \mathrm{O}_{2}$ and $5 \% \mathrm{CO}_{2}(\mathrm{pH} 7.4)$.

\section{Experimental design}

Tracheal smooth muscle response was measured isotonically with a passive weight of $0.5 \mathrm{~g}$ in all experiments. After an equilibration period of $60 \mathrm{~min}$ with four intermediate changes of buffer solution, cumulative doses of methacholine were added to the organ bath solution to obtain a rapid concentration-response curve (these data were not used). After a thirty-minute washing period (with six intermediate changes of buffer solution to remove methacholine), the first concentrationresponse curve with methacholine was performed (indicated as the control curve). Next, the tracheal rings were washed again and incubated with different concentrations of rhTNF $\alpha$ or buffer control for $30 \mathrm{~min}$. Thereafter, the tracheal rings were subjected to a second concentration-response curve with methacholine, either directly (designated the direct curve) or after another thirty minute washing period (designated the delayed curve). During the direct- or delayed-type experiments with TNF $\alpha$, a buffer control curve was also obtained (designated blankcurve).

In order to evaluate the dose-response effects, rhTNF $\alpha$ was administered to the tracheal strips in concentrations ranging from $10^{-13}$ to $10^{-10} \mathrm{M}$. Dose-response effects were assessed in the delayed-type models (i.e. $30 \mathrm{~min}$ of washing after incubation with rhTNF $\alpha$ ). Thereafter, in order to assess the specificity of the effect induced by rhTNF $\alpha$, tracheal rings were simultaneously incubated with $10^{-11} \mathrm{M}$ rhTNF $\alpha$ and $10^{-10} \mathrm{M}$ rh-soluble TNF-receptor-p80. This concentration of rhTNF-receptor-p 80 was shown previously to inactivate the bioactivity of TNF $\alpha$ completely, as assessed by the WEHI-assay [15]. All experiments were performed pairwise in tissues from the same animals.

Since TNF $\alpha$ has been reported to enhance the activity of phospholipase- $\mathrm{A}_{2}$ (PL-A $)$ [18] with subsequent synthesis of prostaglandins and PAF, in the next set of experiments, tracheal strips were preincubated for $10 \mathrm{~min}$ with $10^{-5} \mathrm{M}$ indomethacin or $10^{-6} \mathrm{M}$ WEB 2086, followed by $30 \mathrm{~min}$ of incubation with $10^{-11}$ $\mathrm{M}$ rhTNF $\alpha$. These concentrations of indomethacin and WEB 2086 were considered to block endogenous prostaglandin and PAF effects completely [19]. The sec- 
ond concentration-response curve for methacholine was also performed after washing for $30 \mathrm{~min}$, during which indomethacin and WEB 2086 were continuously present in the washing solution. As before, experiments were performed pairwise in tissues from the same animals.

\section{STATISTICAL ANALYSIS}

Data are presented as mean \pm standard error of the mean (SEM) of at least eight independent experiments. For methacholine concentration-response curves, the contraction obtained following incubation with buffer control or TNF $\alpha$ was expressed as percentage of the initial response (control curve). The results were statistically evaluated using Student's t-test for paired data (two-sided test). A p-value < 0.05 was considered statistically significant.

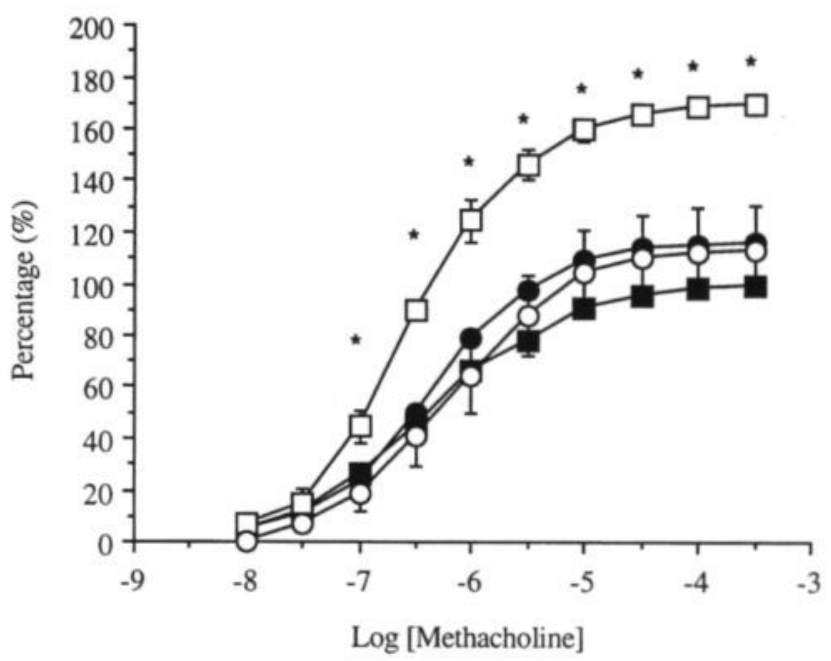

Figure 1. Concentration-response curves of methacholine chloride on isotonic contraction of tracheal strips of the guinea-pig, without control; - blank) and after incubation with $3 \times 10^{-11} \mathrm{M}$ rhTNF $\alpha$ for 30 min ( $\square$ delayed; $O-O$ direct). The response is displayed as percentage of contraction in comparison with the control curve. The curves are the mean \pm SEM of at least eight independent experiments. Experiments were performed pairwise. ${ }^{*} p<0.005$ delayed versus control, blank and direct-type incubation with rhTNF $\alpha$. 


\section{RESULTS}

Effect of TNF $\alpha$ on methacholine induced bronchoconstriction

Incubation of tracheal smooth muscle with $3 \times 10^{-11} \mathrm{M}$ rhTNF $\alpha$ significantly increased the maximum response to methacholine (Figure 1). This enhanced response was, however, only observed in the delayed model $(169.6 \pm 4.3 \%, \mathrm{p}<0.005$ in comparison with the control, blank and direct model). The blank curves (second methacholine concentration-response curve with buffer control) were not statistically different from the first concentration-response-curves, indicating that intermediate changes of buffer or prolonged presence in the organ bath did not influence the contractility of the tracheal strips within the duration of our experiments. During incubation with TNF $\alpha$, the baseline tone of tracheal strips did not change. The -log concentration of drug needed to obtain half maximum response $\left(\mathrm{pD}_{2}\right)$ values of the different curves, both with and without $\mathrm{rhTN} \alpha$, were not statistically different from those of the control curves (Table 1).

In the second set of experiments, the dose-response effects of different concentrations of rhTNF $\alpha\left(10^{-13}\right.$ to $\left.10^{-10} \mathrm{M} \operatorname{rhTNF} \alpha\left(1.7-1700 \mathrm{pg} \cdot \mathrm{mL}^{-1}\right)\right)$ on methacholine-induced contraction of tracheal smooth muscle were evaluated.

Table 1. $\mathrm{pD}_{2}$ values of concentration-response curves to methacholine of tracheal smooth muscle of the guinea-pig.

\begin{tabular}{lll}
\hline & & $\begin{array}{l}\mathrm{pD}_{2} \\
\text { (mean } \pm \text { SEM) }\end{array}$ \\
\hline Control & $6.39 \pm 0.05$ \\
Blank & $6.41 \pm 0.03$ \\
TNF $\alpha$ & $10^{13} \mathrm{M}$ & $6.71 \pm 0.25$ \\
& $10^{-12} \mathrm{M}$ & $6.30 \pm 0.07$ \\
& $10^{-11} \mathrm{M}$ & $6.50 \pm 0.16$ \\
TNF $\alpha$ & $10^{-10} \mathrm{M}$ & $6.26 \pm 0.11$ \\
+ TNFRp80FC & $10^{-11} \mathrm{M}$ & \\
TNF $\alpha$ & $10^{-10} \mathrm{M}$ & $6.37 \pm 0.16$ \\
+ Indomethacin & $10^{-11} \mathrm{M}$ & \\
TNF $\alpha$ & $10^{-5} \mathrm{M}$ & $6.49 \pm 0.22$ \\
+ WEB2086 & $10^{-11} \mathrm{M}$ & $6.34 \pm 0.04$ \\
\hline pD & $10^{-6} \mathrm{M}$ & \\
experiments performed. &
\end{tabular}




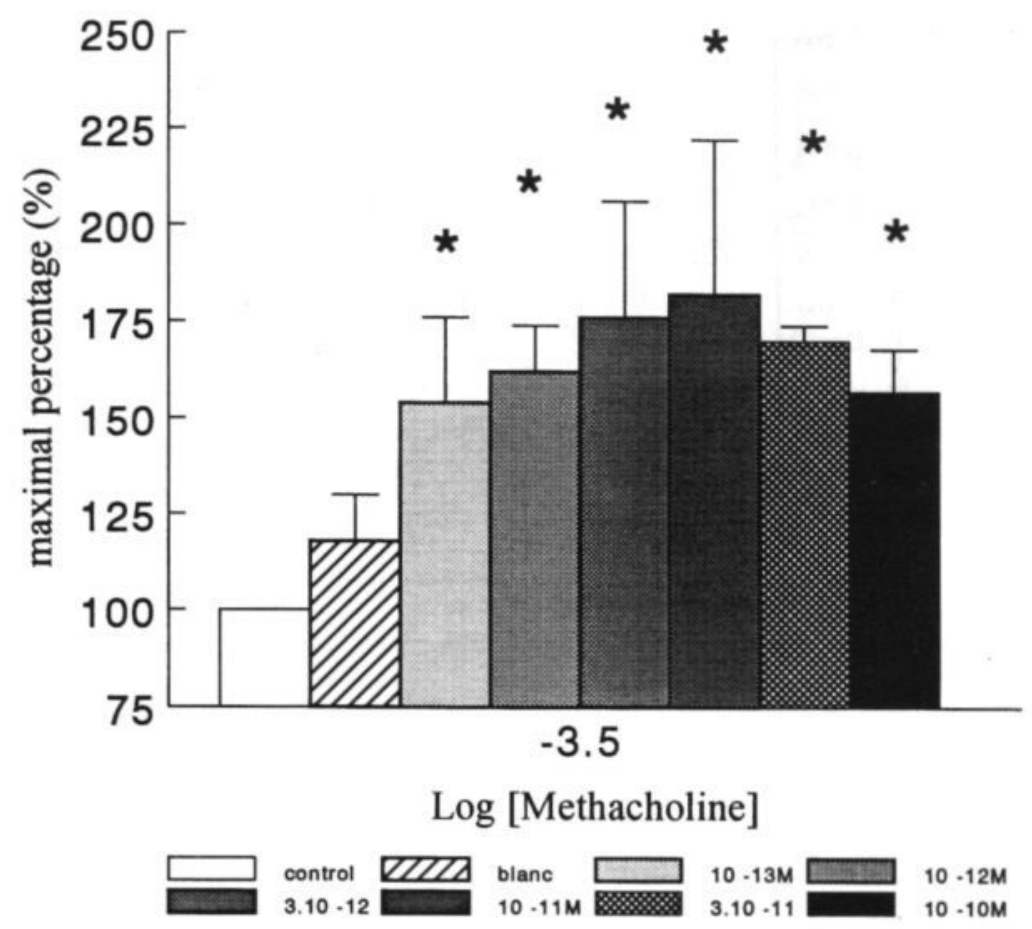

Figure 2. Maximal isotonic contraction to methacholine of tracheal rings of the guinea-pigs without ( control, blank) and with different concentrations of rhTNF $\alpha\left(10^{-13} \mathrm{M}, 10^{-12} \mathrm{M}, 3.10^{-12} \mathrm{M}\right.$, $10^{-11} \mathrm{M}, 3.10^{-11} \mathrm{M}, 10^{-10} \mathrm{M}$ ). The curves were obtained after a 30 min washing period after incubation with TNF $\alpha$ (30 min). Curves are the mean \pm SEM of at least eight independent experiments. ${ }^{\star} p<0.02$ for all concentrations of rhTNF $\alpha$ versus the control and blank.

Considering the results above, in this and the next set of experiments, only the delayed model was used. Our experiments demonstrate that for all concentrations used, rhTNF $\alpha$ increased the maximum response to a similar extent (Figure 2).

Experiments with selective inhibition of TNF $\alpha$ with soluble TNF-receptor construct

In order to ascertain the specificity of action of rhTNF $\alpha$ on tracheal smooth muscle, in the next set of experiments, simultaneous incubation of $10^{-11} \mathrm{M}$ rhTNF $\alpha$ and $10^{-10} \mathrm{M}$ recombinant soluble TNFR-p80:Fc-construct was used (Figure 3). rTNFR-p80:Fc was shown to inhibit the effect of TNF $\alpha$ on tracheal hyperreactivity completely. 


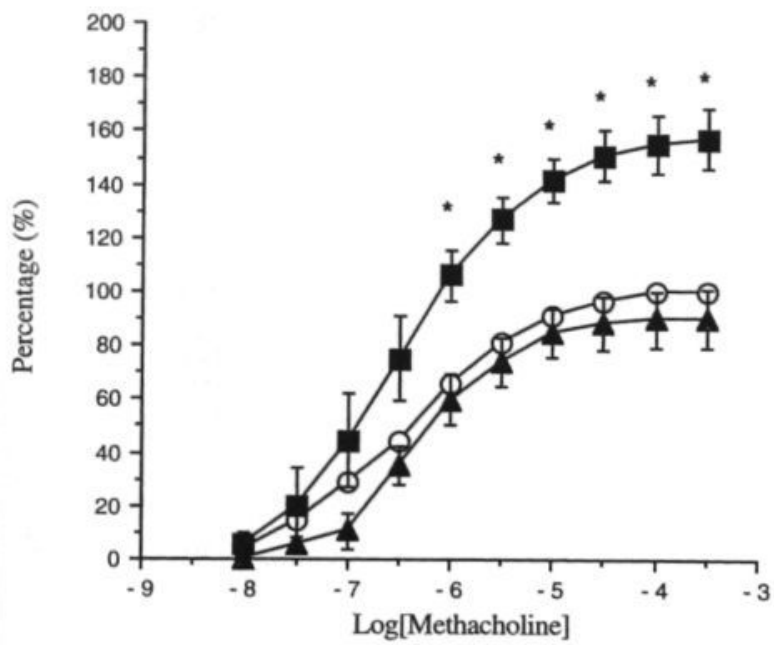

Figure 3. Specific TNF $\alpha$-inhibitor abrogates TNF $\alpha$-induced bronchial hyperreactivity. Concentration-response curves (mean \pm SEM) of methacholine chloride on (at least eight) tracheal strips of the guinea-pig without (O-O blank), with $10^{-11} \mathrm{M}$ rhTNF $\alpha$ (ש- $)$ or simultaneous incubation of $10^{-11} \mathrm{M}$ rhTNF $\alpha$ and $10^{-10} \mathrm{M}$ sTNF-Receptorp80:Fc-construct $(\boldsymbol{\Lambda}-\mathbf{\Delta})$. Curves were obtained $30 \mathrm{~min}$ after incubation with TNF $\alpha$ or buffer control. Experiments were performed pairwise. ${ }^{*} p<0.01$ rhTNF $\alpha$ versus blank and simultaneous incubation of rhTNF $\alpha$ and sTNF-receptor-p80:Fc.

Experiments evaluating involvement of prostaglandins and PAF in TNF $\alpha$-induced bronchial hyperresponsiveness.

Since TNF $\alpha$ increases PL- $\mathrm{A}_{2}$-activity, tracheal rings were incubated with indomethacin to block endogenous prostaglandin release and with WEB 2086 to inhibit PAF effects. As observed before, incubation of tracheal rings with indomethacin alone did induce an increase in contractility, probably induced by shifts occurring within prostaglandin synthesis. Coincubation of tracheal rings with indomethacin $\left(10^{-5} \mathrm{M}\right)$ and rhTNF $\alpha$ did not influence induction of bronchial hyperreactivity by rhTNF $\alpha$ (Figure 4a), indicating that prostaglandin synthesis does not play a direct role in TNF $\alpha$-induced hyperreactivity.

Treatment with WEB $2086\left(10^{-6} \mathrm{M}\right)$ alone did not influence reactivity of tracheal strips, whereas coincubation of WEB 2086 with TNF $\alpha$ completely abrogated TNF $\alpha$-induced hyperreactivity of tracheal smooth muscle (Figure 4b), demonstrating an involvement of PAF in the induction of tracheal hyperreactivity. 

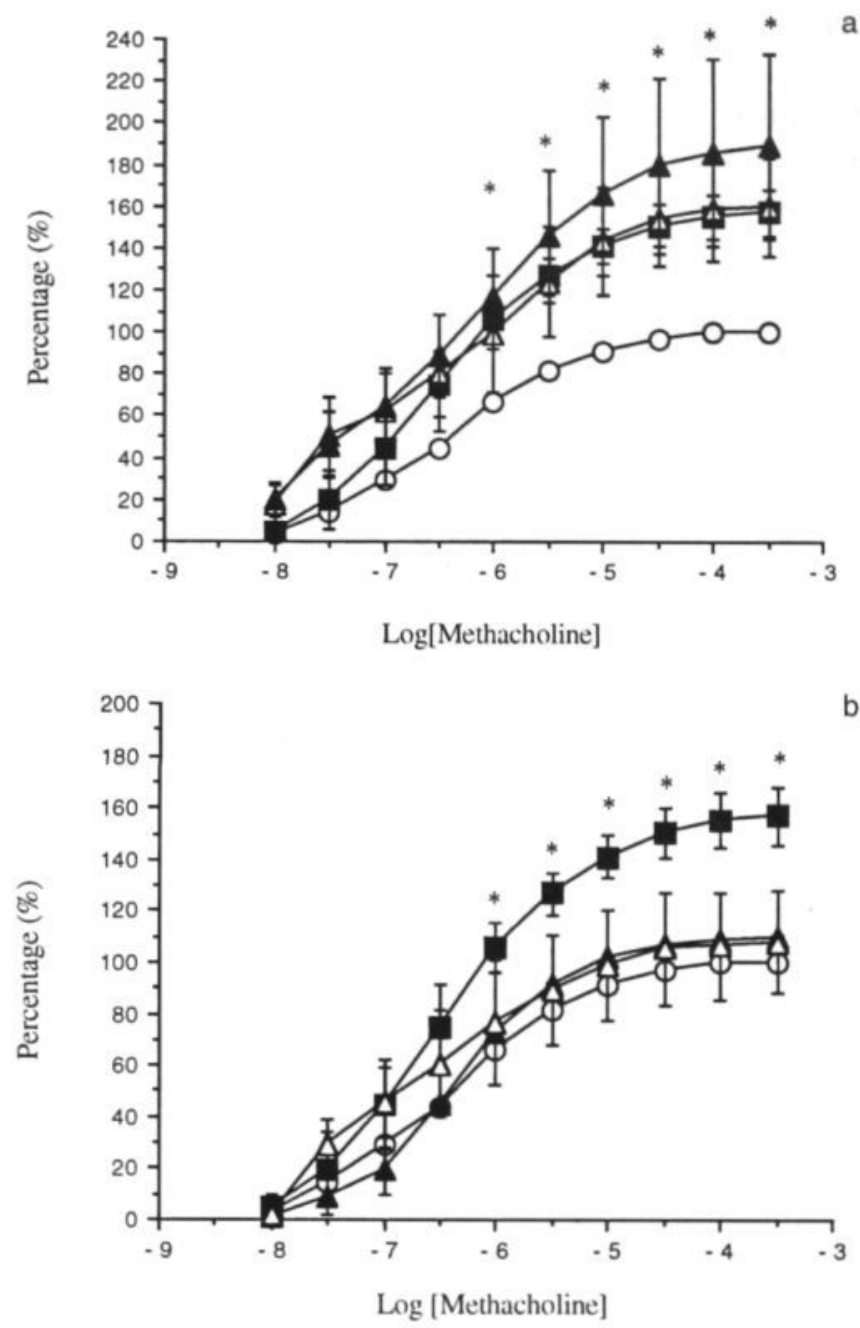

Figure 4 a-b. Effect of: a) Indomethacin and b) WEB 2086 on rhTNF $\alpha$-induced tracheal hyperreactivity. Concentration-response curve (mean \pm SEM) of methacholine on tracheal smooth muscle contraction with buffer control (O-O blank), blank + indomethacin $\left(10^{-5} \mathrm{M}\right)$ or WEB $2086\left(10^{-6} \mathrm{M}\right)$ $(\Delta-\Delta), 10^{-11} \mathrm{M}$ rhTNF $\alpha(-\mathbf{D})$ or preincubation with either indomethacin $\left(10^{-5} \mathrm{M}\right)$ or WEB $2086\left(10^{-6}\right.$ M) followed by incubation with rhTNF $\alpha\left(10^{-11} \mathrm{M}, \boldsymbol{\Delta}-\mathbf{\Delta}\right)$. In a) at least 8 experiments were performed pairwise. ${ }^{*} p<0.01$ rhTNF $\alpha$, blank with indomethacin and ${ }^{\star} p<0.03$ preincubation with indomethacin and rhTNF $\alpha$ versus buffer control. No significant changes were observed between the curves of rhTNF $\alpha 10^{-11} \mathrm{M}$ and the curve of rhTNF $\alpha 10^{-11} \mathrm{M}$, preincubated with indomethacin $10^{-5}$ M. In b) WEB 2086 itself did not influence contractility, whereas preincubation with WEB 2086 completely inhibited TNF $\alpha$-induced tracheal hyperreactivity ( ${ }^{*} p<0.005$ rhTNF $\alpha$ versus buffer control and $p<0.05$ rhTNF $\alpha\left(10^{-11} \mathrm{M}\right)$ versus rhTNF $\alpha\left(10^{-11} \mathrm{M}\right)$ preincubated with WEB 2086. 


\section{DISCUSSION}

The present study demonstrates that rhTNF $\alpha$ induces bronchial hyperreactivity in isolated tracheal rings of the guinea-pig. The specificity of the effect was ascertained by a specific $T N F \alpha$-antagonist that completely inhibited the induction of bronchial hyperreactivity. Additionally, we demonstrated that PAF is involved in the induction of hyperreactivity by TNF $\alpha$.

TNF $\alpha$ has been shown to be involved in the development of BHR, both in animal models [4] as well as in humans [10]. However, these studies did not show whether TNF $\alpha$ affects bronchial smooth muscle directly or whether TNF $\alpha$ initiates mediator release from other cells within the pulmonary compartment, which secondarily induce BHR. In the present study, rhTNF $\alpha$ induced BHR in isolated tracheal rings of the guinea-pig. The effects of TNF $\alpha$ were observed at concentrations comparable with the levels found in bronchoalveolar lavage fluid of asthmatic patients $\left(10^{-12} \mathrm{M}\right)[5]$.

So far, few studies have evaluated the effects of TNF $\alpha$ on bronchial contractility in vitro. The limited data available are difficult to interpret due to different experimental designs. Prolonged incubation $(18 \mathrm{~h})$ with TNF $\alpha\left(100 \mathrm{ng} \cdot \mathrm{mL}^{-1}\right)$ of isolated tracheas of sensitized guinea-pigs did not affect carbamylcholine-induced maximum contraction [20]. More recently, the effect of rhTNF $\alpha$ on isometric contractility of human bronchial rings was evaluated [21]. In this study, TNF $\alpha$ increased the maximum response to $113 \%$. In accordance with the present study, the investigators also observed a time delay before the onset of the effect, with the first response starting between 8 and 16 min after incubation. Concentrations above $10^{-9} \mathrm{M}$ rhTNF $\alpha$ induced an increased response, and in agreement with our observations, no clear dose-response effect with regard to TNF $\alpha$-induced hypercontractility was observed.

TNF $\alpha$ has been shown to enhance phospholipase- $A_{2}$ activity in various cells, leading to synthesis of PAF $[18,22]$. Our experiments demonstrated that PAF is involved in the TNF $\alpha$-induced hypercontractility of tracheal rings in vitro. PAF has a wide range of target cells, including smooth muscle cells. Moreover, PAF has been shown to induce BHR to histamine and methacholine in guinea-pigs $[23,24]$. This study did not clarify the cellular source of PAF synthesis in tracheal rings after stimulation with TNF $\alpha$. TNF $\alpha$ has been shown to induce PAF synthesis within cells present in tracheal rings, such as endothelial and bronchial epithelial cells and also in macrophages, monocytes and neutrophils $[22,25,26]$. Studies with activated rat macrophages have shown that after $\mathrm{TNF} \alpha$-activation, at least 1 $h$ is needed to detect PAF in supernatant, whereas endothelial cells release PAF not before $2 \mathrm{~h} \mathrm{[22].} \mathrm{In} \mathrm{the} \mathrm{previous} \mathrm{experiments,} \mathrm{PAF} \mathrm{was} \mathrm{shown} \mathrm{to} \mathrm{be} \mathrm{largely} \mathrm{retained}$ within the cell in the first few hours following stimulation. Considering the time delay in our experiment after TNF $\alpha$ stimulation, the present study suggests that 
either smooth muscle cells in tracheal rings interact with cells expressing PAF at their surface or synthesize PAF themselves [27]. The present experiment does not permit us to specify the cellular source of PAF synthesis.

TNF $\alpha$ was also shown to influence intracellular $\left[\mathrm{Ca}^{2+}\right]$ in smooth muscle cells of guinea-pigs [28]. TNF $\alpha\left(10 \mathrm{ng} \cdot \mathrm{mL}^{-1}\right)$ induced large increases in cytosolic free $\left[\mathrm{Ca}^{2+}\right]$ after bradykinin stimulation. Since PAF synthesis is associated with calcium mobilisation, PAF synthesis may also be involved in these experiments.

The present study did observe a steep dose-response effect for TNF $\alpha$-induced hypercontractility. This observation concurs with studies in human bronchial rings [21]. A steep dose-response effect for TNF $\alpha$-induced PAF synthesis was observed in macrophages and endothelial cells [22], whereas monocytes did not demonstrate a dose-response effect [26]. In these experiments, TNF $\alpha$ concentrations as low as $1 \mathrm{ng} \cdot \mathrm{mL}^{-1}$ were shown to induce PAF synthesis, whereas PAF has been shown to possess an median effective concentration $\left(\mathrm{EC}_{50}\right)$ value of $10 \mathrm{pM}$ in isolated ileal smooth muscle cells of guinea-pigs [29]. Therefore, the absence of a clear dose-response effect of TNF $\alpha$ in the present study may be explained by assuming a threshold for TNF $\alpha$ effects.

In humans, both TNF $\alpha$ and PAF have been implicated in the inflammatory process of asthma $[1,6]$. So far, studies with PAF antagonists in asthma have yielded disappointing results. However, recently a new, very efficient PAF antagonist was shown to reduce BHR in stable asthmatic patients [30]. The importance of PAF in asthma was further emphasized by the demonstration of a deficiency in PAFacetylhydrolase activity in a subgroup of asthmatic patients [31]. If TNF $\alpha$ in vivo leads to PAF production, selective inhibition of TNF $\alpha$ itself or its release may prove more efficient in asthma treatment than PAF antagonists. In this context, it should be mentioned that a potent inhibitory TNF-receptor construct was recently shown to reduce both BHR and inflammatory cell influx in the late asthmatic response in guinea-pigs [32].

In conclusion, our study shows that TNF $\alpha$ induces hyperreactivity in tracheal rings and that this hyperreactivity is PAF-mediated. TNF $\alpha$ represents a common pathway for different stimuli to generate bronchial hyperresponsiveness in respiratory disease, like allergic inflammatory lung disease, viral and bacterial infections and in occupational asthma. Considering the central and pro-inflammatory role of TNF $\alpha$ in the pathogenesis of asthma, early inhibition of events leading to BHR using specific (inhaled) TNF $\alpha$-antagonists or TNF $\alpha$-release blocking agents may prove beneficial. 


\section{REFERENCES}

1. Clark TJH, Godfrey S, Lee TH. Asthma. Chapman and Hall, London. 3rd edition. 1992; 108-132.

2. Michel O, Ginanni R, Le Bon B, Content J, Duchateau J, Sergysels R. Inflammatory response to acute inhalation of endotoxin in asthmatic patients. Am Rev Respir Dis 1992; 146: 352-357.

3. Michie HR, Manogue KR, Spriggs DR, Revhaug A, O'Dwyer S, Dinarello CA, Cerami A, Wolff SM, Wilmore DW. Detection of circulating tumor necrosis factor after endotoxin administration. N Engl J Med 1988; 318: 1481-1486.

4. Kips JC, Tavernier J, Pauwels RA. Tumor necrosis factor causes bronchial hyperresponsiveness in rats. Am Rev Respir Dis 1992; 145: 332-336.

5. Virchow JC, Walker C, Hafner D, Kortsik C, Werner P, Matthys H, Kroegel C. T-cells and cytokines in broncho-alveolar lavage fluid after segmental allergen provocation in atopic asthma. Am J Respir Crit Care Med 1995; 151: 960-968.

6. Keatings VM, O'Connor BJ, Wright LG, Huston DP, Corrigan CJ, Barnes PJ. Late response to allergen is associated with increased concentrations of tumor necrosis factor- $\alpha$ and IL- 5 in induced sputum. J Allergy Clin Immunol 1997; 99: 693-698.

7. Broide DH, Lotz M, Cuomo AJ, Coburn DA, Federman EC, Wasserman SI. Cytokines in symptomatic asthma airways. J Allergy Clin Immunol 1992; 89: 958-967.

8. Ackerman V, Marini M, Vittori E, Bellini A, Vassali G, Mattoli S. Detection of cytokines and their cell sources in bronchial biopy specimens from asthmatic patients. Relationship to atopic status, symptoms, and level of airway hyperresponsiveness. Chest 1994; 105: 687-696.

9. Maestrelli P, Di Stefano A, Occari P, Turato G, Milani G, Pivirotto F, Mapp CE, Fabbri LM, Saetta M. Cytokines in the airway mucosa of subjects with asthma induced by toluene diisocyanate. Am J Respir Crit Care Med 1995; 151: 607-612.

10. Thomas WS, Yates DH, Barnes PJ. Tumor necrosis factor- $\alpha$ increases airway responsiveness and sputum neutrophilia in normal human subjects. Am J Respir Crit Care Med 1995; 152: 76-80.

11. Beutler B, Cerami A. The biology of cachectin/TNF-a primary mediator of the host response. Ann Rev Immunol 1989; 7: 625-655.

12. Cembrzynska-Nowak M, Sklarz E, Inglot AD, Teodorczyk-Injeyan JA. Elevated release of Tumor necrosis factor-alpha and Interferon-gamma by bronchoalveolar leucocytes from patients with bronchial asthma. Am Rev Respir Dis 1993; 147: 291-295.

13. Ohkawara Y, Yamauchi K, Tanno Y, Tamura G, Ohtani H, Nagura H, Ohkuda K, Takishima T. Human lung mast cells and pulmonary macrophages produce Tumor necrosis factor- $\alpha$ in sensitized lung tissue after IgE receptor triggering. Am J Respir Cell Mol Biol 1992; 7: 385-392.

14. Robinson DS, Hamid Q, Sun Y, Tsicopoulos A, Barkans J, Bentley AM, Corrigan C, Durham SR, Kay AB. Predominant Th2-like bronchoalveolar T-lymphocyte population in atopic asthma. $N$ Engl J Med 1992; 326: 298-304.

15. Mohler KM, Torrance DS, Smith CA, Goodwin RG, Stremler KE, Fung VP, Madani H, Widmer MB. Soluble Tumor Necrosis Factor (TNF) receptors are effective therapeutic agents in lethal endotoxemia and function simultaneously as both TNF carriers and TNF antagonists. J Immunol 1993; 151: 1548-1561.

16. Weber $\mathrm{KH}$, Heuer $\mathrm{H}$. Structure-activity relationships and effects of Platelet-activating factor antagonists in the hetrazepine series. Int Arch Allergy Appl Immunol 1989; 88: 82-87

17. Kramer K, Doelman CJA, Timmerman H, Bast A. A disbalance between beta-adrenergic and muscarinic responses caused by hydrogen peroxide in rat airways in vitro. Biochem Biophys Res Commun 1987; 145: 357-362.

18. Bauldry SE, Mccall CE, Cousart SL, Bass DA. Tumor necrosis factor- $\alpha$ priming of Phospholipase $A_{2}$ activation in human neutrophils. An alternative mechanism of priming. $J$ Immunol 1991; 146: 1277-1285. 
19. Brunelleschi S, Renzi D, Ledda F, Giotti A, Fantozzi R, Brink C, Benveniste J. Interference of WEB 2086 and BN 52021 with PAF-induced effects on guinea-pig trachea. Br J Pharmacol 1989; 97: 469-474.

20. Wills-Karp M, Uchida Y, Lee JY, Jinot J, Hirata A, Hirata F. Organ Culture with Proinflammatory Cytokines Reproduces Impairment of the B-Adrenoceptor-mediated Relaxation in Tracheas of a Guinea Pig Antigen Model. Am J Respir Cell Mol Biol 1993; 8: 153-159.

21. Anticevich SZ, Hughes JM, Black JL, Armour CL. Induction of human airway hyperresponsiveness by tumour necrosis factor- $\alpha$. Eur J Pharmacol 1995: 284: 221-225.

22. Camussi G, Bussolino F, Salvidio G, Baglioni C. Tumor necrosis factor/cachectin stimulates peritoneal macrophages, polymorphonuclear neutrophils, and vascular endothelial cells to synthesize and release Platelet-activating factor. J Exp Med 1987; 166: 1390-1404.

23. Mazzoni L. Morley J, Page CP, Sanjar S. Induction of airway-hyperreactivity by platelet-activating factor in the guinea pig. J Physiology 1985; 365: 107P

24. Robertson DN, Coyle AJ, Rhoden KJ, Grandordy B, Page CP, Barnes PJ. The effect of Plateletactivating Factor on histamine and muscarinic receptor function in guinea pig airways. Am Rev Respir Dis 1988; 137: 1317-1322.

25. Shelhaemer JH, Levine SJ, Tong Wu, Jacoby DB, Kaliner MA, Rennard SI. Airway Inflammation. Ann Intern Med 1995; 123: 288-304.

26. Valone FH, Epstein LB. Biphasic Platelet-activating Factor synthesis by human monocytes stimulated with IL-1B, tumor necrosis factor or IFN- $\gamma$. J Immunol 1988; 141: 3945-3950.

27. Tomlinson PR, Croft K, Harris T, Stewart AG. Platelet-activating Factor biosynthesis in rat vascular smooth muscle cells. J Vasc Res 1994; 31: 144-152.

28. Amrani $Y$, Bronner $C$. Tumor necrosis factor alpha potentiates the increase in cytosolic free calcium induced by bradykinin in guinea-pig tracheal smooth muscle cells. CR Acad Sci Paris 1993; 316: 1489-1494.

29. Jeanneton O, Delvaux M, Botella A, Frexinos J, Bueno L. Platelet-activating Factor (PAF) induces a contraction of isolated smooth muscle cells from guinea pig ileum: intracellular pathway involved. J Pharmacol Exp Ther 1993; 267: 31-37.

30. Hozawa S, Haruta Y, Ishioka S, Yamakido M. Effects of a PAF-antagonist, Y-24180, on bronchial hyperresponsiveness in patients with asthma. Am J Respir Crit Care Med 1995; 152: 1198-1202.

31. Stafforini DM, Satoh K, Atkinson DL, Tjoelker LW, Eberhardt C, Yoshida H, Imaizumi T, Takamatsu S, Zimmerman GA, Mcintyre TM, Gray PW, Prescott SM. Platelet-activating factor acetylhydrolase deficiency. A missense mutation near the active site of an anti-inflammatory phospholipase. J Clin Invest 1996: 97: 2784-2791.

32. Renzetti LM, Paciorek PM, Tannu SA, Rinaldi NC, Tocker JE, Wasserman MA, Gater PR. Pharmacological evidence for tumor necrosis factor as a mediator of allergic inflammation in the airways. J Pharmacol Exp Ther 1996; 278: 847-853. 



\section{Evaluation of immunomodulatory properties of theophylline; an in vitro study in human cells}

HJ Pennings, MA Dentener, S Verploegen", SH Korn", FBJM Thunnissen "', WA Buurman", EFM Wouters

From the Department of Department of Pulmonology', University Hospital Maastricht, Department of Surgery " and Department of Pathology "', Maastricht University, Maastricht, The Netherlands. 


\section{ABSTRACT}

Recently, theophylline has been shown to possess immunomodulatory capacities besides inducing bronchodilation. Aim of the present study was to evaluate the effect of theophylline on different cell populations within human lung tissue, involved in the pathogenesis of asthma.

Human peripheral blood monocytes, alveolar macrophages and cultured endothelial cells were stimulated with LPS or TNF- $\alpha$ in the presence of theophylline $(5-100 \mu \mathrm{g} / \mathrm{ml})$. Release of TNF- $\alpha$, IL-6, IL-8, IL-10, sTNFR s $_{s}$ and sTNFR, was measured in supernatant of cell-cultures and expression of adhesion molecules on endothelial cells was evaluated.

In monocytes, theophylline significantly inhibited release of TNF- $\alpha$ and to a lesser extent of IL-6 ( $p=0.04)$. Theophylline inhibited TNF- $\alpha$ release in a dosedependent way. Northern blot analysis in monocytes demonstrated that theophylline $(20 \mu \mathrm{g} / \mathrm{ml})$ inhibited production of TNF- $\alpha$ mRNA (inhibition of $59 \pm 8 \%$ $($ mean \pm SEM) $)$ and IL- 6 mRNA (inhibition of $49 \pm 8 \%($ mean \pm SEM $)$ ) in comparison to LPS alone. In monocytes, theophylline was also shown to increase $\mathrm{TNFR}_{15}$ shedding for low concentrations of LPS, whereas for high concentrations of LPS theophylline was shown to decrease TNFR, shedding ( $p=0.04$ ). In human endothelial cells, theophylline was shown to attenuate VCAM-1 expression in TNF- $\alpha$ stimulated cells ( $\mathrm{p}=0.03$ ). Theophylline did not influence release of mediators in alveolar macrophages, although a trend towards enhancement of IL-8 release was observed.

In conclusion, our study demonstrated anti-inflammatory properties of theophylline, especially in concentrations clinically used. It supports evidence for an immunomodulatory role of theophylline in the treatment of asthmatic patients.

\section{INTRODUCTION}

Theophylline is one of the most widely prescribed drugs for asthma-treatment in the world. In the past, the primary goal for its use was considered relaxation of bronchial smooth muscle. Theophylline is a non-selective phosphodiesterase inhibitor and relaxation of airway smooth muscle is widely held to be induced by the elevation of intracellular cAMP and cGMP. However, in recent years several clinical studies have implicated additional effects of theophylline in asthma treatment besides bronchodilation. Clinical studies have shown inhibitory effects of theophylline on the late asthmatic response (LAR), a response which is considered to be associated with airway inflammation $[1,2,3]$. In addition, theophylline induced in asthmatic patients changes in T-cell subsets in peripheral blood both in stable condition [4] and after antigen-challenge [1]. Also, the observation that theophyl- 
line reduces both total and relative numbers of activated eosinophils in the bronchial mucosa in LAR further supports its anti-inflammatory effect [5]. Withdrawal of theophylline in stable asthmatic patients leads to deterioration of asthma clinically and accumulation of T-lymphocytes in airway epithelium [6]. In addition to the observed effects in vivo, theophylline has immunomodulatory effects in vitro which have recently been reviewed [7]. Theophylline shares antiinflammatory properties with a wider range of phosphodiesterase inhibitors like pentoxifylline $[8,9,10]$ and HWA $138[11]$. These compounds have been shown to be effective in in vivo models of endotoxin induced cytokine release $[8,11,12]$ and a common observation is inhibition of TNF- $\alpha$ release. In asthma, TNF- $\alpha$ and IL-6 release have been reported to be elevated in BAL-fluid after allergen challenge [13] and in stimulated BAL-leucocytes [14]. Also, TNF- $\alpha$ has been shown in healthy human volunteers to induce bronchial hyperresponsiveness [15]. TNF- $\alpha$ is a very potent stimulator of adhesion molecule expression and therefore may play an important role in upregulating adhesion-molecule expression in bronchial mucosa, an important characteristic in asthma $[16,17,18]$.

So far, few reports have extensively investigated the immunomodulatory role of theophylline in regard to cytokine release and adhesion molecule expression in the various cell types present within the human airways. In this study, we have investigated the influence of theophylline on the response of human monocytes, alveolar macrophages and endothelial cells to cytokines and LPS.

\section{MATERIAL AND METHODS}

\section{Reagents}

Recombinant human (rh) TNF- $\alpha$ was kindly provided by BASF/Knoll (Ludwigshafen, FRG). Fibronectin was kindly provided by Dr. van Mourik (CLB, Amsterdam, The Netherlands). LPS (from Escherichia Coli, Serotype 055:LB5), heparin, and L-isoproterenol, were purchased from Sigma (St. Louis, MO), theophylline from OPG-farma (Utrecht, The Netherlands) and endothelial cell growth supplement from Collaborative Research Incorporated (Bedford, MA). RPMI-1640, was obtained from Gibco Europe (Paisley, Scotland) and DMEM and HAM's F12 from ICN Biomedic Inc. (Costa Mesa, CA). Bovine calf serum (BCS) was purchased from HyClone (Logan, UT) and foetal calf serum (FCS) from Boehringer Mannheim (Mannheim, Germany). Human serum (HS), obtained from healthy donors at the Red Cross blood bank Zuid Limburg (Maastricht, The Netherlands) after informed consent for research was given, was pooled and sterilized by $0.2 \mu \mathrm{m}$ filter. The sera, which were heated at $56^{\circ} \mathrm{C}$ for 30 
minutes before storage at $4^{\circ} \mathrm{C}$, contained $<5 \mathrm{pg} / \mathrm{ml}$ endotoxin, as determined in the Limulus-assay (Coatest, KabiVitrum, Stockholm, Sweden).

GTC-solution consisted of $4 \mathrm{mM}$ guanidinium isothiocyanate, $25 \mathrm{mM}$ sodium acetate, $118 \mathrm{mM}$ 2-mercaptoethanol, $18 \mathrm{mM} \mathrm{N}$-lauroylsarcosine; $\mathrm{CsCl}$-solution consisted of $5.7 \mathrm{M}$ caesiumchloride, $4 \mathrm{Mm}$ tetrasodiumsalt-dihydrat $\mathrm{pH}$ 8.0; HES solution: $10 \mathrm{mM}$ HEPES $\mathrm{pH} 7.4,5 \mathrm{mM}$ tetrasodiumsaltdihydrat $\mathrm{pH} 7.5$, $0.1 \%$ sodium dodecyl sulfate; $10^{*}$ MPS: $200 \mathrm{mM} 3$-morpholinopropane sulfonic acid, $80 \mathrm{mM}$ sodium acetate and $10 \mathrm{mM}$ tetrasodiumsaltdihydrat; $20 *$ SSC: $3 \mathrm{M}$ sodium chloride, $0.33 \mathrm{M}$ sodium citrate.

Probes: IL-6 probe: $0.3 \mathrm{~kb}$ HIII-EcoRI fragment in bluescribe M13, kindly provided by Dr. L. Aarden, CLB, Amsterdam, The Netherlands; TNF $\alpha$-probe: 0.615 kd EcoRI-Cla fragment in plasmid pMG199, kindly provided by M. Robinson, Celltech, Slough, UK, and the glyceraldehyde-3-phosphate dehydrogenase (GAPDH) probe: $1.007 \mathrm{~kb}$ EcoRI-BamHI fragment in plasmid PSKII+, kindly provided by Dr. R.G. Crystal, National Institute of Health, Bethesda, MA.

\section{CELLS}

Monocytes were obtained from blood kindly provided by the Red Cross Blood Bank Zuid Limburg, donated by volunteers, which gave informed consent for research. Monocytes were isolated as described previously [19]. In short, mononuclear cells obtained after Lymphoprep (Nycomed, Oslo, Norway) centrifugation were allowed to clump by low speed centrifugation at $4^{\circ} \mathrm{C}$. Cell clumps were separated from the rest of the cells by sedimentation through ice-cold BCS. The obtained cell suspensions consisted for 80 to $95 \%$ of monocytes.

Alveolar macrophages (AM) were recovered from the lung by bronchoalveolar lavage (BAL) obtained during fiberoptic bronchoscopy of volunteers without underlying pulmonary pathology, after informed consent had been obtained. The lavage was performed in the following way: $200 \mathrm{~mL}$ of $\mathrm{NaCl} 0.9 \%$, prewarmed at $37^{\circ} \mathrm{C}$, was instilled into a bronchial segment, in four aliquots. Each aliquot was aspirated immediately after inspiration. The first aliquot was discarded, whereas the second, third and fourth aliquot were pooled and filtered through a sterile nylon gauze. Total cell content, which consisted for $>90 \%$ of AM, were used for stimulation experiments.

Human umbilical vein endothelial cells (HUVEC) were obtained by collagenase treatment of the human umbilical vein, as described previously [20]. The cells were cultured in fibronectin coated tissue culture flasks (Costar, Cambridge, MA) in medium consisting of RPMI-1640,10\% HS, $10 \%$ BCS, $50 \mu \mathrm{g} / \mathrm{ml}$ heparin, 30 $\mu \mathrm{g} / \mathrm{ml}$ endothelial cell growth supplement and antibiotics. 


\section{STUDY-DESIGN}

Monocytes and AM $\left(5^{*} 10^{5}\right.$ cells $\left./ \mathrm{ml}\right)$ were cultured in 96-well flat bottom tissue culture plates (Costar) in standard medium consisting of RPMI-1640, 10\% BCS and antibiotics. Cells were preincubated for 4 hours with different concentrations of theophylline, followed by a 18 hour incubation period with a concentration range of LPS. The supernatants were harvested and kept at $-20^{\circ} \mathrm{C}$ until determination of inflammatory mediator levels.

To study the effect of theophylline on LPS-induced monocyte-activation at mRNA levels, mononuclear leucocyte fraction of blood was used, to prevent loss of monocytes during the isolation procedure. Contaminating lymphocytes did not disturb this assay since they do not respond to LPS by producing TNF $\alpha$ or IL-6. Cells ( $30 \mathrm{ml} \mathrm{a} 3^{*} 10^{6} / \mathrm{ml}$ ), incubated in tissue flasks, were 45 minutes preincubated with theophylline $(20 \mu \mathrm{g} / \mathrm{ml})$. After 3 hours stimulation with LPS (1 $\mu \mathrm{g} / \mathrm{ml}$ ), cells were treated as indicated below for analysis of mRNA content.

HUVEC of passage 3 were seeded at $10^{4}$ cells/well in fibronectin-coated 96-well flat-bottom tissue culture plates in culture medium as decribed above, one or two days prior to stimulation. When HUVEC monolayers were confluent, cells were rinsed once with RPMI-3\% BCS, and cells were stimulated in standard medium. After 4 hours preincubation with theophylline, cells were stimulated with LPS or TNF $\alpha$. For analysis of cell surface expression of E-selectin, cells were stimulated for 5 hours whereas for detection of ICAM- 1 and VCAM-1 expression, and for release of IL-6 and IL-8 in culture supernatant, cells were stimulated during 18 hours. Supernatant was harvested and stored at $-20^{\circ} \mathrm{C}$, until analysis, whereas cells were fixed for detection of adhesion molecule expression, as described below.

\section{Assays for inflammatory mediators in supernatant}

TNF- $\alpha$, IL-6, IL-8, IL-10, soluble TNF-Receptor-55 (sTNFR ss $_{\text {) }}$ and sTNFR, $\left(\right.$ sTNFR $\left._{15}\right)$-levels in the culture supernatants were determined using sandwichELISA's as described previously [21,22,23,24]. In short, for measurement of $\mathrm{TNF} \alpha \mathrm{mAb} 61 \mathrm{E} 71$ was used as catching reagent, whereas specific polyclonal rabbit anti-human TNF $\alpha$ Ab was used for detection. rhTNF $\alpha$ was used as standard, and the detection limit of the assay was $10 \mathrm{pg} / \mathrm{ml}$. For measurement of IL- $6, \mathrm{mAb}$ $5 \mathrm{E} 1$ was used as catching reagent and specific polyclonal rabbit anti-human IL-6 Ab for detection. The standard rhIL-6 was kindly provided by prof W. Sebald, Physiologisch-Chemisches Institut der Universität, Würzburg, Germany, and the detection limit of the assay was $10 \mathrm{pg} / \mathrm{ml}$. mAb HM. 5 was used for catching of IL-8, whereas IL-8 was detected by biotin labeled polyclonal rabbit anti-human IL-8 IgG. rhIL-8 used as standard was kindly provided by dr. Lindley, Sandoz Forschungsinstitute. IL- 8 could be detected with a lower detection limit of 10 
pg/ml. For IL-10 measurement, mAB HB11677 (rat-anti-human IL-10) was used as catching antibody, whereas biotinylated $\mathrm{mAB}$ HB1 1677 was used for detection of IL-10. Both HB11677 and rh-IL10 were kindly provided by dr. van de Waal Malefyt (DNAX, Palo Alto, CA). The detection limit for the IL-10 assay was 20 $\mathrm{pg} / \mathrm{ml}$. For measurement of sTNFR ${ }_{s 5}$ and $s \mathrm{TNFR}_{5}, \mathrm{mAb}_{\mathrm{NR} 1-1}$ and MR2-2 were used as catching reagent respectively. Specific biotin labeled polyclonal rabbit anti-human sTNFR IgG were used as detector reagents. The standards used were rh-sTNFR s $_{5}$ and rh-sTNFR, kindly provided by M. Bodmer (Celltech, Slough, UK). The detection limit of both assays was $100 \mathrm{pg} / \mathrm{ml}$.

96-Well immuno maxisorp plates (Nunc, Roskilde, Denmark) were used for the ELISA assay. Biotinylated samples were analyzed with peroxidase labeled streptavidine (Dako, Glostrup, Denmark), whereas non-labeled rabbit anti-human Ab were detected by peroxidase conjugated goat anti-rabbit IgG (Jackson, Westgrove, PA). Peroxidase activity was determined by addition of TMB (3,3',5,5'tetramethylbenzidine) substrate (Kirkegaard \& Perry Lab., Gaithersburg, MD) and photospectrometry $(450 \mathrm{~nm})$ was performed using a micro-ELISA autoreader.

\section{Adhesion molecule expression}

For detection of adhesion molecule expression, HUVEC were washed with phosphate-buffered saline (PBS) supplemented with $4 \mathrm{mM} \mathrm{Ca++}$ and $2.5 \mathrm{mM}$ $\mathrm{Mg++}$, and fixed with $0.025 \%$ glutaraldehyde for $10 \mathrm{~min}$ at room temperature (RT). Cell-surface expression of E-selectin, ICAM-1 and VCAM-1 was detected by incubation for $2 \mathrm{~h}$ at RT with mAbs ENA-1 (anti-E-selectin) [25], RR-1 (antiICAM-1, a kind gift of Dr. R. Rothlein, Boehringer Ingelheim Pharmaceuticals, Inc., Ridgefield, CT) and 1G11 (anti-VCAM-1, a kind gift of Dr. D.O. Haskard, Hammersmith Hospital, Department of Rheumatology, London, U.K. [26]) respectively, followed by incubation with peroxidase-conjugated goat anti-mouse IgG (Jackson ImmunoResearch, West Grove, PA) for 1 h. Peroxidase activity was determined as described above.

mRNA analysis

RNA was isolated from cells as described by Davis et al. [27], using a 4M GTCsolution. The ultracentrifugation, northern blot analysis, hybridization (including GAPDH as control probe) and semiquantitative analysis was performed as described before [28]. mRNA expression of TNF $\alpha$ and IL-6 was determined relatively to the expression of the control gene GAPDH. The hybridization signals were analyzed semiquantitatively with a phosphor-imaging system (Molecular Dynamics, Sunnyvale, CA). 
The results shown are expressed as mean \pm SEM of independent experiments, unless otherwise specified. Cytokine release in each individual experiment represents the mean of four replicates. Differences within groups were analyzed using twotailed Wilcoxon signed-rank test for paired data. In order to evaluate doseresponse effects for theophylline in the experiments with monocytes and alveolar macrophages, the slope of cytokine-release for different concentrations of theophylline was calculated in individual experiments for each concentration of LPS. The slope was defined by the formula $\left(-3 Y_{1}-Y_{2}+Y_{3}+3 Y_{4}\right) / 10$ [29], wherein $Y_{1}, Y_{2}, Y_{3}$ and $\mathrm{Y}_{4}$ stand for cytokine-release respectively at concentrations $0,5,20$ and 80 $\mu \mathrm{g} / \mathrm{ml}$ of theophylline. In each experiment the calculated slope was tested by Wilcoxon signed-rank test against the hypothesis that the slope equalled 0 ( $=$ no doseresponse effect). A p-value $<0.05$ was considered statistically significant.

\section{RESULTS}

\section{Effect of theophylline on monocytes}

Stimulation of monocytes with a concentration-range of LPS for 18 hours resulted in a dose-dependent increase in release of TNF- $\alpha$, IL- $6, \mathrm{IL}-8$ and shedding of TNF-R, (Fig. 1). No significant spontaneous release was observed for TNF $\alpha$, whereas we detected spontaneous release for IL-6, IL-8 and TNF-R, Theophylline (concentrations $5-80 \mu \mathrm{g} / \mathrm{ml}$ ) exhibited a significant inhibition of LPSinduced TNF $\alpha$-release, maximum inhibition observed amounted $79 \pm 6 \%$ SEM $(\mathrm{p}=0.04)$. Dose-dependent inhibition of TNF $\alpha$ release by theophylline was demonstrated for 10 and $1000 \mathrm{ng} / \mathrm{ml} \mathrm{LPS}$, as demonstrated by statistically significant slopes for the concentrations of theophylline used ( $\mathrm{p}=0.02$ ). IL- 6 release was moderately inhibited by theophylline (Fig. 1b). In most experiments, a small decrease in IL-6 release was observed for all concentrations of theophylline used, however statistical significance was only achieved with LPS $10 \mathrm{ng} / \mathrm{ml}$ and theophylline 5 and $20 \mu \mathrm{g} / \mathrm{ml}$ ( $\mathrm{p}=0.04)$. In contrast to the effect upon LPS induced TNF- $\alpha$ and IL-6 release, theophylline did not affect IL-8 release (Fig. 1c). Theophylline influenced release of TNF- $\mathrm{R}_{\text {, }}$ in two different ways: at a low concentration of LPS $(100 \mathrm{pg} / \mathrm{ml})$, theophylline induced a dose-related increase in $s$ TNF- $\mathrm{R}_{t s}(\mathrm{p}=0.04)$, whereas at $1000 \mathrm{ng} / \mathrm{ml}$ LPS theophylline significantly decreased sTNF-R, in a dose-dependent way ( $\mathrm{p}=0.04$ ) (Fig. 1d).

Experiments, evaluating the involvement of IL-10 release in theophylline induced inhibition of TNF $\alpha$ and IL- 6 release, demonstrated that LPS induced a dosedependent increase in IL-10 release (Fig. 2). However, whereas theophylline was 


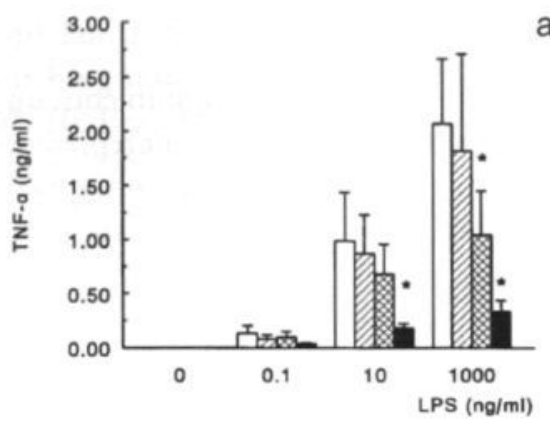

a
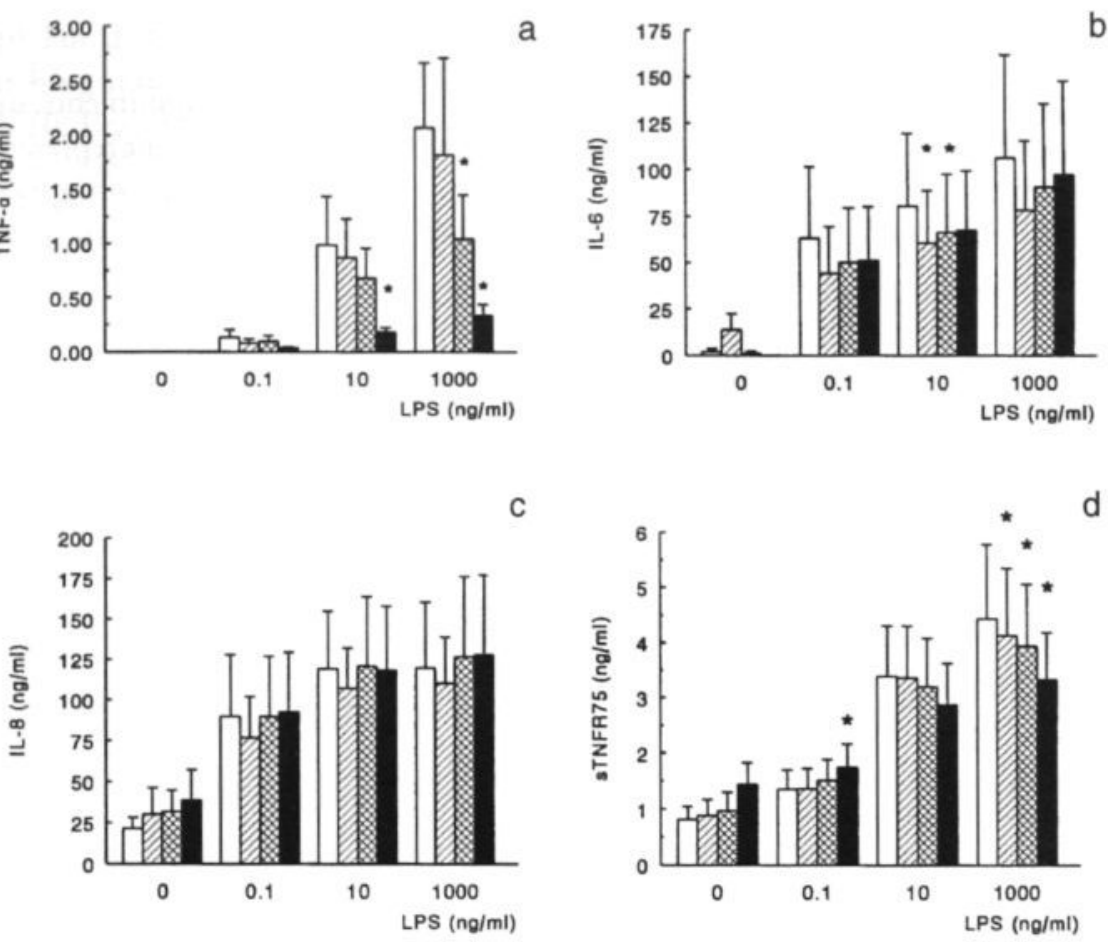

Figure 1. Effects of theophylline on a:) TNF- $\alpha-$, b:) IL-6-, c:) IL-8- and d:) STNFR r release in peripheral blood monocytes. Monocytes $\left(5.10^{5}\right.$ cells $\left./ \mathrm{ml}\right)$, preincubated for 4 hours with different concentrations of theophylline (open bars: control medium; hatched bars: $5 \mu \mathrm{g} / \mathrm{ml}$; double-hatched bars: $20 \mu \mathrm{g} / \mathrm{ml}$; solid bars: $80 \mu \mathrm{g} / \mathrm{ml}$ ), were incubated overnight with a concentration range of LPS. Data are expressed as mean \pm SEM of five experiments. Theophylline inhibits TNF- $\alpha$ release and induces a moderate inhibition of IL- 6 release in LPS-stimulated monocytes ( $\mathrm{*}=0.04$ in comparison to control), whereas theophylline did not modulate IL- 8 release. Theophylline induces an inhibition of sTNF-R75 release in monocytes in the higher concentration range of LPS, whereas in the lower concentration of LPS theophylline induces an increase in TNF-R75 shedding (* $p=0.04$ in comparison to control).

shown to inhibit cytokine release at LPS concentrations of 10 and $1000 \mathrm{ng} / \mathrm{ml}$, no significant changes were observed in IL-10 release within the duration of the experiments. Moreover, a trend towards inhibition of IL-10 release was observed for monocytes, coincubated with theophylline and LPS $(100 \mathrm{ng} / \mathrm{ml}$ and 1 $\mu \mathrm{g} / \mathrm{ml})(\mathrm{p}=0.07)$. 


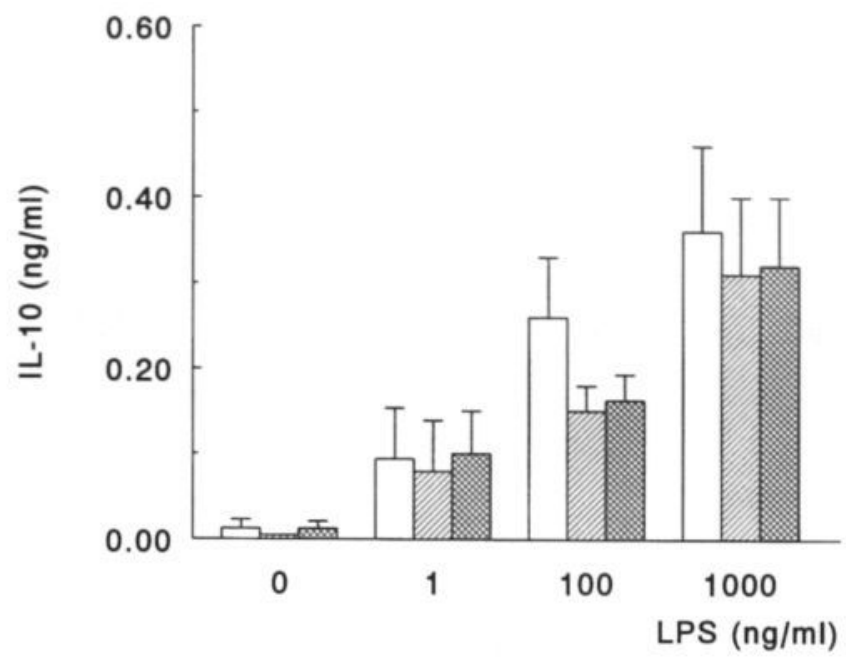

Figure 2. Theophylline does not influence IL-10 release in LPS-stimulated monocytes. Monocytes $\left(5.10^{5}\right.$ cells $\left./ \mathrm{ml}\right)$, preincubated for 4 hours with different concentrations of theophylline (open bars: control medium; hatched bars: $5 \mu \mathrm{g} / \mathrm{ml}$; double-hatched bars: $20 \mu \mathrm{g} / \mathrm{ml}$ ), were incubated overnight with a concentration range of LPS. Data are expressed as mean \pm SEM of four experiments. A trend towards a reduction of IL-10 release was observed $(p=0.07)$.

Effect of theophylline on alveolar macrophages

As expected, stimulation of alveolar macrophages with LPS during 18 hours induced a dose-dependent increase in TNF- $\alpha$, IL-6 and IL-8 release (Fig. 3a-c). Alveolar macrophages produced greater quantities of TNF- $\alpha$ and IL- 8 in comparison to peripheral blood monocytes. LPS induced dose-dependent shedding of TNF- $\mathrm{R}_{\text {, }}$ in alveolar macrophages comparable to results obtained in peripheral blood monocytes (Fig. 3d). In contrast to monocytes, alveolar macrophages did also shed TNF- $\mathrm{R}_{s,}$, however quantities were small and no dose-response relation to LPS was observed (data not shown). Theophylline did not affect TNF- $\alpha$, IL-6, $s T N F-R_{s s}$ or $s T N F-R_{s s}$ release by alveolar macrophages, in contrast to results obtained in monocytes. Moreover, theophylline appeared to induce a dosedependent increase in IL-8 release in LPS-stimulated alveolar macrophages (slope $\mathrm{p}=0.07$ ) (Fig. 3c). 

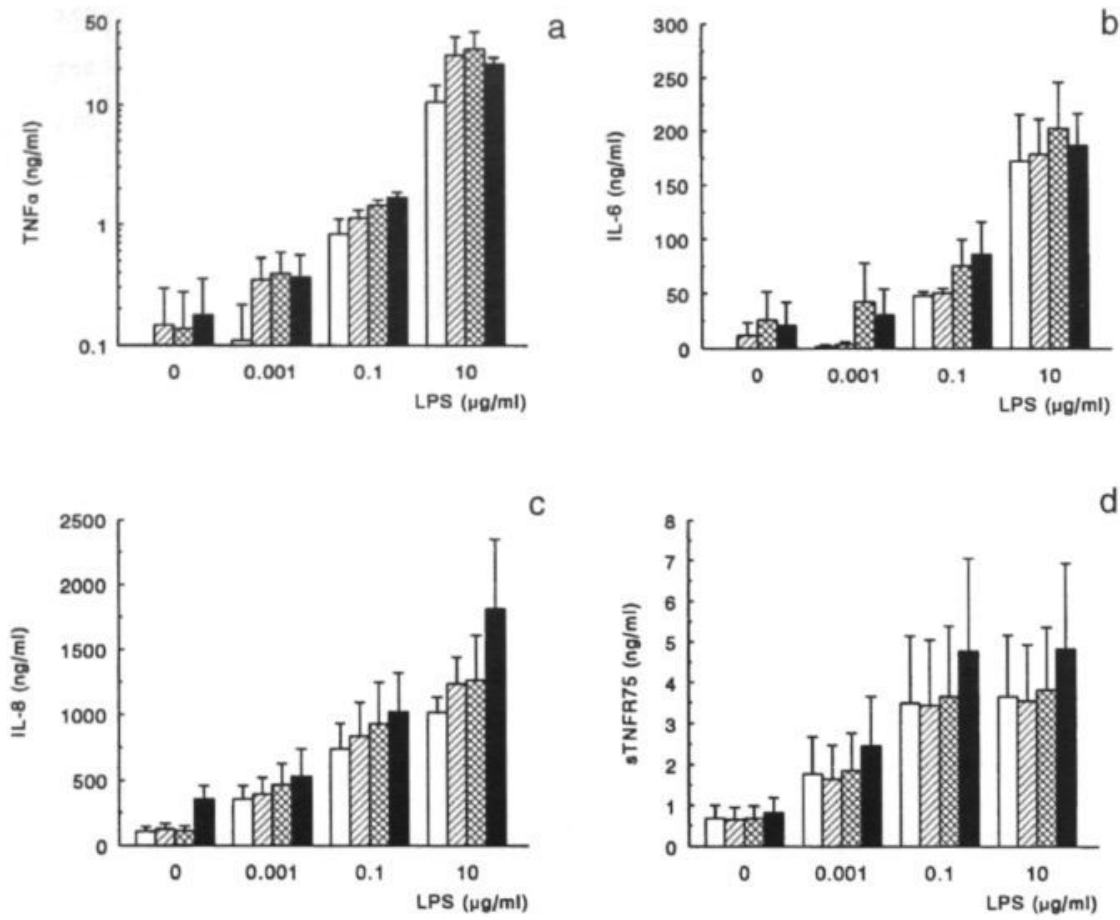

C

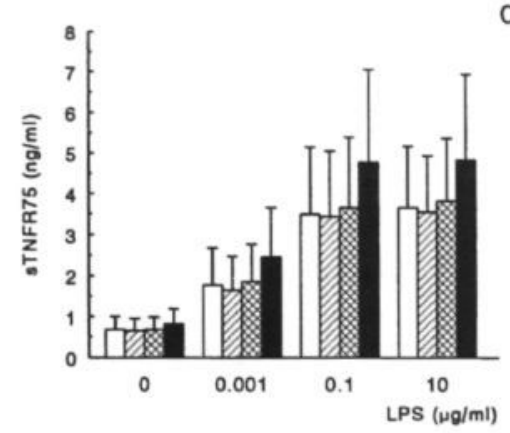

Figure 3. Effect of theophylline on a:) TNF- $\alpha-$, b:) IL-6-, c:) IL-8-and d:) STNF-R r $_{5}$ release in alveolar macrophages. Alveolar macrophages $\left(5.10^{5} \mathrm{cell} / \mathrm{s} / \mathrm{ml}\right)$ were isolated from BAL-fluid, preincubated for 4 hours with different concentrations of theophylline (open bars: control medium; hatched bars: $5 \mu \mathrm{g} / \mathrm{ml}$; double-hatched bars: $20 \mu \mathrm{g} / \mathrm{ml}$; solid bars: $80 \mu \mathrm{g} / \mathrm{ml}$ ) and thereafter incubated overnight with a concentration range of LPS. Data are expressed as mean \pm SEM of four experiments. Theophylline did not modulate TNF- $\alpha$ nor IL- 6 release, whereas a moderate enhancement of IL- 8 release by theophylline was observed. In contrast to monocytes, theophylline did not influence STNFR $_{75}$ release in alveolar macrophages.

Effect of theophylline on endothelial (HUVEC) cells

Both LPS and TNF- $\alpha$ stimulated endothelial cells showed a dose-response effect for expression of E-selectin (after 5 hours) and ICAM-1 and VCAM-1 (after 18 hours) (Fig. 4). TNF- $\alpha$ stimulated expression of adhesion-molecules at lower concentrations than LPS. Theophylline $(100 \mu \mathrm{g} / \mathrm{ml})$ significantly attenuated VCAM-1 expression in TNF- $\alpha$ stimulated HUVEC ( $p=0.03$ ). No effect of theophylline was observed on LPS- or TNF- $\alpha$ stimulated expression of ICAM- 1 and E-selectin. 


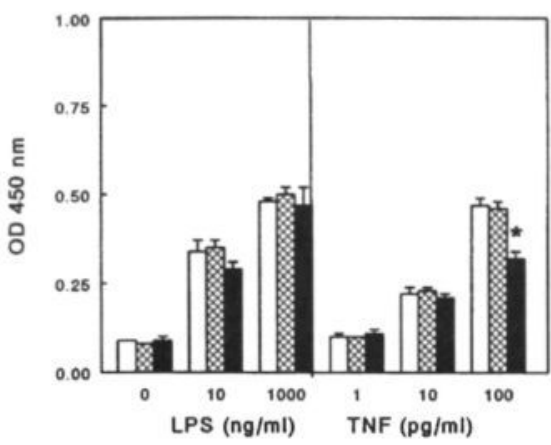

ICAM-1

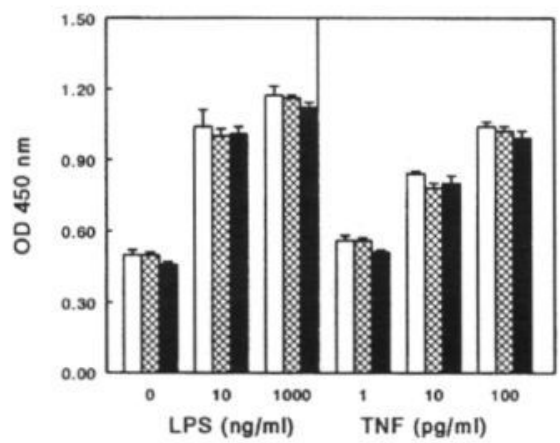

E-selectin

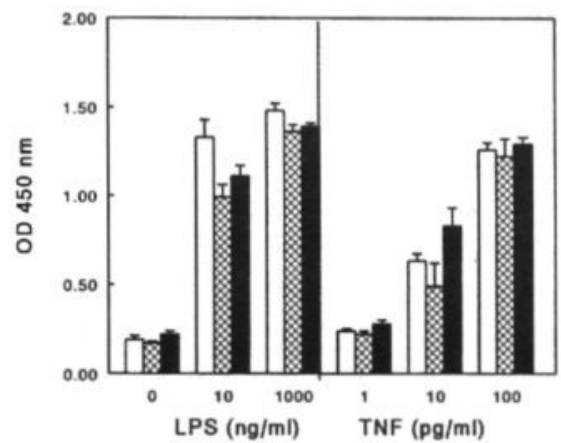

Figure 4. Effect of theophylline on expression of a:) VCAM-1, b:) ICAM-1 and c:) E-Selectin-1 in LPS- and TNF- $\alpha$-stimulated HUVEC. Endothelial cells were isolated, preincubated for 4 hours with theophylline (open bars: control medium; double-hatched bars: $20 \mu \mathrm{g} / \mathrm{ml}$; solid bars: $100 \mu \mathrm{g} / \mathrm{ml}$ ) and thereafter stimulated for 5 ( E-selectin) or 18 hours (VCAM-1, ICAM-1) with LPS (0, 10 and $1000 \mathrm{ng} / \mathrm{ml})$ and TNF- $\alpha(1,10,100 \mathrm{pg} / \mathrm{ml})$. Data are expressed as mean $\pm \mathrm{SD}$. The experiment was repeated at least four times; results of one representive experiment are given. Theophylline in high concentration $(100 \mu \mathrm{g} / \mathrm{ml})$ significantly attenuated TNF- $\alpha$ induced VCAM-1 expression on HUVEC $\left({ }^{*} \mathrm{p}=0.03\right)$.

LPS and TNF- $\alpha$ also dose-dependently stimulated IL-6 and IL-8 release in HUVEC. Theophylline did not influence IL-8 release. Although theophylline attenuated IL-6 release in some cultures, this effect was only observed in high concentrations $(100 \mu \mathrm{g} / \mathrm{ml})$ and was not consistent (data not shown). 


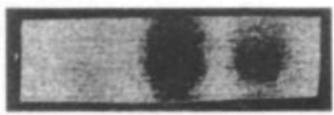

\section{TNFa}

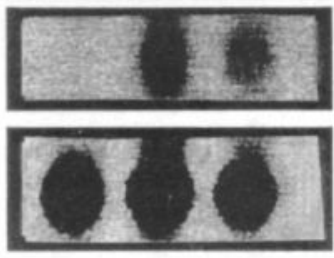

IL-6

\section{GAPDH}

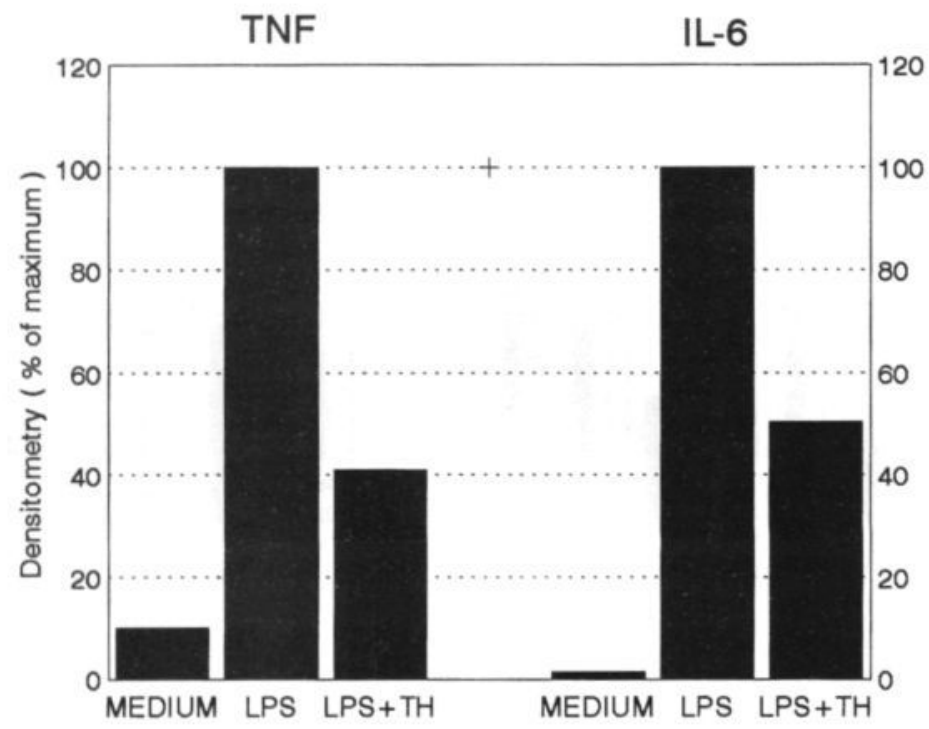

Figure 5. Theophylline inhibits TNF- $\alpha$ and IL-6-mRNA accumulation in LPS stimulated peripheral blood mononuclear cells. Cells ( $30 \mathrm{ml}$, concentration $3.10^{6} / \mathrm{ml}$ ) were preincubated for 45 minutes with theophylline $(20 \mu \mathrm{g} / \mathrm{ml})$ or medium and subsequently stimulated with LPS $(1 \mu \mathrm{g} / \mathrm{ml})$ for 3 hours. The experiment was repeated three times. The upper panel shows representive Northern blot autoradiographs for TNF- $\alpha$-, IL- 6 and GAPDH mRNA. The left lane represents culture medium, the medium lane culture medium with LPS $(1 \mu \mathrm{g} / \mathrm{ml})$ and the right lane represents cells, preincubated with theophylline $(20 \mu \mathrm{g} / \mathrm{ml})$ and stimulated with LPS $(1 \mu \mathrm{g} / \mathrm{ml})$. The lower panel represents phosphor-densitometry, wherein theophylline was shown to reduce TNF- $\alpha$ mRNA by $59 \%$ and IL- 6 mRNA by $49 \%$ in comparison to stimulation with LPS alone. 
Effect of theophylline on the transcription of TNF- $\alpha$ and IL- 6 in LPS-stimulated peripheral blood mononuclear cells.

After isolation of peripheral blood mononuclear cells (PBMC) and culturing in regular medium, only very small amounts of mRNA for TNF- $\alpha$ and IL- 6 were detectable. Incubation of PBMC with LPS resulted in a distinct increase in TNF- $\alpha$ and IL-6-mRNA. In all three experiments performed, the same pattern was observed; theophylline $(20 \mu \mathrm{g} / \mathrm{ml})$ inhibited LPS-induced TNF- $\alpha$ mRNA accumulation $59 \pm 8 \%$ (mean \pm SEM of three experiments) in comparison to LPS and inhibited LPS-induced IL-6 mRNA accumulation $49 \pm 8 \%$ (mean \pm SEM) in comparison to LPS (Fig. 5).

\section{DISCUSSION}

In our study, theophylline inhibited LPS-induced TNF- $\alpha$ release in peripheral blood monocytes dose-dependently. Theophylline also decreased LPS-induced TNF- $\alpha$ mRNA accumulation. Also for IL-6, both in supernatant and on mRNAlevel, theophylline was shown to inhibit IL-6 production. Our study confirmed observations from previous studies, demonstrating that theophylline [30] and other xanthines $[9,10,31]$ inhibit TNF- $\alpha$ production in monocytic cells. Recently, specific type IV and III/IV phosphodiesterase (PDE)-inhibitors were also found to inhibit LPS-induced TNF- $\alpha$ release in mouse peritoneal macrophages $[32,33]$. Data from studies with $\mathrm{PGE}_{2}[34,35,36]$, PDE-inhibitors and cAMPelevating agents $[9,33]$ relate the observed inhibition of TNF- $\alpha$ to the increase in intracellular cAMP. However, a discrepancy remains between the observed inhibition of TNF $\alpha$ release and accumulation of cAMP, as was shown with pentoxifylline $(250 \mu \mathrm{M})$, that induced only minor increases in intracellular cAMP, whereas evident inhibition of TNF- $\alpha$ was observed [37]. Therefore, additional pathways may be involved in the inhibitory effect of theophylline on TNF $\alpha$ release.

An explanation may be provided by studies with $\mathrm{PGE}_{2}$, implying involvement of IL-10 in modulation of cytokine release [38]. PGE, enhanced IL-10 production in LPS-stimulated murine peritoneal macrophages and IL-10 was shown to be involved in the inhibition of TNF $\alpha$ and IL- 6 release. Therefore, the mechanism of theophylline or other PDE-inhibitors might also involve IL-10. The present study showed that theophylline did not enhance levels of IL-10, whereas a clear inhibition of TNF $\alpha$ was observed. These observations do not fit in with observations from a previous study with specific type IV PDE-inhibitors, that decreased TNF $\alpha$ release, while at the same time enhanced levels of IL-10 were observed [33]. These specific type-IV PDE-inhibitors were shown to inhibit TNF $\alpha$ release at much lower concentrations than theophylline in the present study. Although higher 
concentrations of theophylline might enhance IL-10 release, these concentrations are toxic in patients. The observed trend towards a decrease in IL-10 release, observed with different concentrations of theophylline in the present study, may be explained by TNF $\alpha$. Since TNF $\alpha$ is able to enhance IL-10 release in monocytes [39], decreased levels of TNF $\alpha$, induced by theophylline, may secondarily lead to reduced levels of IL-10 in supernatant.

The inhibition of TNF $\alpha$ mRNA accumulation by theophylline in human cells, observed in the present study, are in line with data from murine macrophages [9]. The present study suggests that theophylline primarily inhibits TNF $\alpha$-mRNA accumulation, whereas IL-10 might be involved in the late phase inhibition of TNF $\alpha$ release, although this was not observed in the present study. cAMP might be involved in both pathways since cAMP inhibits TNF $\alpha$ gene-transcription [40] and enhances IL-10 release, since the IL-10 gene contains a cAMP responsive element [39].

In the present study, theophylline was also shown to inhibit IL-6 production in LPS stimulated monocytes, although to a lesser degree than TNF- $\alpha$. The inhibition was more prominent on mRNA-level than on protein level, suggesting that post-transcriptional mechanisms are involved, which compensate for effects of theophylline on mRNA. This observation is clearly different from observations in previous studies, that showed no influence of methylxanthines on IL-6 [12,32]. In contrast, specific type IV phophodiesterase inhibitors, mentioned above, were also shown to inhibit IL-6 release in peritoneal macrophages [33]. It may be argued that the downregulation of IL- 6 mRNA, observed in the present study, may occur as a result of the decreased release of TNF $\alpha$, since it is known that TNF- $\alpha$ stimulates IL-6 release, certainly within the time-span of our experiment [41]. However, observations of evident downregulation of IL-6 mRNA 3 hours after LPSstimulation do not favour the influence of TNF- $\alpha$, since at that moment TNF- $\alpha$ release has just started.

We also investigated the influence of theophylline on IL-8 release. IL- 8 belongs to the family of C-X-C-chemokines and represents a powerful neutrophilic chemoattractant and activator. Alveolar macrophages were shown to be very potent producers of IL-8 in comparison to peripheral blood monocytes. Although IL-8 release was not influenced by theophylline in monocytes, theophylline appeared to enhance LPS-induced IL-8 release in alveolar macrophages. In contrast to peripheral blood monocytes, theophylline did not influence cytokine release in LPSstimulated alveolar macrophages. This observation is in line with previous observations, wherein 1000 -fold higher concentrations of $\mathrm{PGE}_{2}$ were needed for similar inhibition of TNF- $\alpha$ release in human alveolar macrophages in comparison to PBMC [42]. The different effects of theophylline on alveolar macrophages and blood monocytes can be explained by differences in PDE-activity or PDE- 
isoenzyme distribution within cell populations [43]. Moreover, differences may exist within macrophage cell populations, since, in contrast to data presented above, pentoxifylline induced a $50 \%$ inhibition in TNF- $\alpha$ release in human interstitial pulmonary macrophages [44].

Since adhesion-molecules play an important role in leucocyte-trafficking and therefore represent a potential target for immunomodulation, the influence of theophylline on the expression of adhesion-molecules on endothelial cells was evaluated. Theophylline partially inhibited TNF- $\alpha$ induced VCAM-1 expression, whereas no influence was observed on E-selectin and ICAM-1 expression. VCAM-1 is a member of the immunoglobulin superfamily and interacts with the integrin very late antigen-4 (VLA-4) on circulating lymphocytes and eosinophils and plays a role in lymphocyte trafficking to sites of inflammation. Our observations are in line with studies reporting similar inhibitory effects of caffeine (10 $\mathrm{mM}$ ) on IFN- $\gamma$ stimulated VCAM-1 expression in murine endothelial cells [45] and the effects of forskolin and isobutylmethylxanthine on VCAM-1 expression in TNF- $\alpha$ stimulated HUVEC [46]. Furthermore, modulation of VCAM-1 expression by theophylline could explain accumulation of activated T-lymphocytes in the bronchial mucosa, observed after withdrawal of theophylline in stable asthmatic patients [6].

Our study confirmed previous observations, that LPS enhances TNF-receptor shedding in peripheral blood monocytes [47] and, in addition, showed that LPS induced TNF-receptor shedding in human alveolar macrophages. Different patterns in TNF-receptor shedding were observed between monocytes and alveolar macrophages: in monocytes, LPS induced release of sTNF-R, whereas in alveolar macrophages release of both TNF- $\mathrm{R}_{\text {s }}$ and TNF- $\mathrm{R}_{5,}$ was observed, both spontaneously and after LPS-stimulation. Interestingly, TNF- $\mathrm{R}_{45}$ shedding was more influenced by LPS than TNF- $\mathrm{R}_{5}$, in contrast to data from a previous report [48]. In monocytes, a dichotomy was observed in the response to LPS: theophylline increased TNF-R, shedding in low concentrations of LPS, whereas, for high concentrations of LPS theophylline decreased shedding of TNF- $\mathrm{R}_{55}$. The decrease of TNF- $\mathrm{R}_{15}$ shedding could be due to a direct effect of theophylline or due to the inhibition of TNF- $\alpha$ release, induced by theophylline. Our results concur with in vivo effects of pentoxifylline and chlorpromazine in LPS-treated mice [8]. Despite TNF- $\alpha$ reduction by pentoxyfylline and chlorpromazine, only for chlorpromazine a significant decrease in sTNF- $R_{s,}$ was observed. Biological effects of enhanced TNF-receptor shedding are not clear, however studies have implicated a role for sTNF-R, in neutralization of TNF- $\alpha$ in vivo $[49,50]$.

Our study demonstrated relatively modest immunomodulatory effects of theophylline in vitro. Animal studies have observed that theophylline inhibited the in- 
flammatory reaction and the development of bronchial hyperresponsiveness after allergen-exposure [51,52,53,54]. In human studies, the role of theophylline in asthma management is undisputed, both in low and high concentrations $[1,2,3,5,6,55]$. The different magnitudes of effect, observed in in vitro experiments and effects of theophylline in vivo, can be explained in some ways. Cells, used in the present study, were obtained from healthy human volunteers, in whom theophylline in therapeutic concentrations induces a relatively minor inhibition of phosphodiesterase activity $[56,57]$. In atopic disease, theophylline inhibits PDEactivity more efficiently in cells from atopic individuals than from healthy individuals, probably due to an increased expression of phosphodiesterase [58]. This may explain why theophylline induces bronchodilation in asthmatic patients, whereas it lacks bronchodilatory effects in normal individuals [59]. Therefore, the immunomodulatory effects of theophylline, observed in the present study, may be magnified in atopic disease and may explain part of the beneficial effects of theophylline, observed in studies with asthmatic patients [55].

\section{ACKNOWLEDGEMENT}

This study was supported by a grant from $3 \mathrm{M}$, The Netherlands.

\section{REFERENCES}

1. Ward JM, McKenniff M, Evans JM, Page CV, Costello JF. Theophylline-an immunomodulatory role in asthma? Am Rev Respir Dis 1993; 147: 518-523.

2. Pauwels R, Van Renterghem D, Van der Straeten M, Johannesson N, Persson CGA. The effect of theophylline and enprofylline on allergen induced bronchoconstriction. J Allergy Clin Immunol 1985; 76: 583-590.

3. Crescioli S, Spinazzi A, Paleari D, Pozzan M, Mapp CE, Fabbri LM. Theophylline inhibits early and late asthmatic reactions induced by allergens in atopic subjects with asthma. Am Rev Respir Dis 1988; 137: A35.

4. Fink G, Mittelman M, Shohat B, Spitzer SA. Theophylline-induced alterations in cellular immunity in asthmatic patients. Clin Allergy 1987; 17: 313-316.

5. Sullivan P, Bekir S, Jaffar Z, Page C, Jeffery P, Costello J. Anti-inflammatory effects of low-dose oral theophylline in atopic asthma. Lancet 1994; 343: 1006-1008.

6. Kidney J, Domingez M, Taylor PM, Rose M, Chung KF, Barnes PJ. Immunomodulation by theophylline in asthma. Am J Respir Crit Care Med 1995; 151: 1907-1914.

7. Barnes PJ, Pauwels RA. Theophylline in the management of asthma:time for reappraisal? Eur Respir J 1994; 7: 579-591.

8. Netea MG, Blok WL, Kullberg B-J, Bemelmans M, Vogels MTE, Buurman WA, Van der Meer JWM. Pharmacologic inhibitors of Tumor Necrosis Factor production exert differential effects in lethal endotoxemia and in infection with live microorganisms in mice. $J$ Infect Dis 1995; 171: 393-399. 
9. Strieter RM, Remick DG, Ward PA, Spengler RN, Lynch JP, Larrick J, Kunkel SL. Cellular and molecular regulation of tumor necrosis factor- $\alpha$ production by pentoxifylline. Biochem Biophys Res Comm 1988; 155: 1230-1236.

10. Neuner P, Klosner G, Schauer E, Pourmojib M, Macheiner W, Grünwald C, Knobler R, Schwarz A, Luger TA, Schwarz T. Pentoxifylline in vivo downregulates the release of IL-1B, IL-6, IL- 8 and tumour necrosis factor- $\alpha$ by human peripheral blood mononuclear cells. Immunology 1994; 83; 262-267.

11. Bahrami S, Redl H, Buurman WA, Schlag G. Influence of the xanthine derivate HWA 138 on endotoxin-related coagulation disturbances: effects in non-sensitized versus D-galactosamine sensitized rats. Thromb Haemostasis 1992; 68: 418-423.

12. Zabel P, Wolter DT, Schönharting MM, Schade UF. Oxpentifylline in endotoxaemia. Lancet 1989; 1474-1477.

13. Gosset Ph, Tsicopoulos A, Wallaert B, Vannimenus C, Joseph M, Tonnel A, Capron A. Increased secretion of tumor necrosis factor- $\alpha$ and interleukin- 6 by alveolar macrophages consecutive to the development of the late asthmatic reaction. I Allergy Clin Immunol 1991; 88: 561-571.

14. Cembrzynska-Nowak M, Sklarz E, Inglot AD, Teodorczyk-Injeyan JA. Elevated release of Tumor necrosis factor-alpha and Interferon-gamma by bronchoalveolar leucocytes from patients with bronchial asthma. Am Rev Respir Dis 1993; 147: 291-295.

15. Thomas PS, Yates DH, Barnes PJ. Tumor necrosis factor- $\alpha$ increases airway responsiveness and sputum neutrophilia in normal human subjects. Am J Respir Crit Care Med 1995; 152: 76-80.

16. Gosset Ph, Tillie- Leblond IT, Janin A, Marquette C-H, Copin M-C, Wallaert B, Tonnel A-B. Expression of E-selectin, ICAM-1 and VCAM-1 on bronchial biopsies from allergic and non-allergic asthmatic patients. Int Arch Allergy Immunol 1995; 106: 69-77.

17. Vignola AM, Campbell AL, Chanez P, Bousquet J, Lacoste PP, Michel FB, Godard Ph. HLA-DR and ICAM-1 expression on epithelial cells in asthma and chronic bronchitis. Am Rev Respir Dis. 1993; 148: 689-694.

18. Bentley AM, Durham SR, Robinson DS, Menz G, Storz C, Cromwell O, Kay AB, Wardlow AJ. Expression of endothelial and leucocyte adhesion molecules intercellular adhesion molecule-1, E-selectin, and vascular cell adhesion molecule-1 in the bronchial mucosa in steady-state and allergen-induced asthma. J Allergy Clin Immunol 1993; 92: 857-868.

19. Graziano RF, Fanger MW. Human monocyte-mediated cytotoxicity: the use of Ig-bearing hybridomas as target cells to detect trigger molecules on the monocyte cell surface. J Immunol 1987; 138: 945-950.

20. Leeuwenberg JFM, Jeunhomme GMAA, Buurman WA. Adhesion of polymorphonuclear celis to human endothelial cells. Adhesion-molecule-dependent and Fc receptor-mediated adhesion-molecule-independent mechanisms. Clin Exp Immunol 1990; 81: 496-500.

21. Engelberts I, Möller A, Schoen GJM, Van Der Linden CJ, Buurman WA. Evaluation of measurement of human TNF- $\alpha$ in plasma by ELISA. Lymphokine Cytok Res 1991; 10: 69-67.

22. Dentener MA, Bazil V, Von Asmuth EJU, Ceska M, Buurman WA. Involvement of CD14 in lipopolysaccharide-induced tumor necrosis factor- $\alpha, \mathrm{IL}-6$ and IL- 8 release by human monocytes and alveolar macrophages. J Immunol 1993; 150: 2885-2891.

23. Bouma MG, Stad RK, van den Wildenberg FAJM, Buurman WA. Differential regulatory effects of adenosine on cytokine release by activated human monocytes. I Immunol 1994; 153: 4159-4168.

24. Leeuwenberg JFM, Jeunhomme TMAA, Buurman WA. Slow release of soluble TNF-Receptors by monocytes in vitro. J Immunol 1994; 152: 4036-4043.

25. Leeuwenberg JFM, Jeunhomme TMAA, Buurman WA. Role of ELAM-1 in adhesion of monocytes to activated human endothelial cells. Scand J Immunol 1992; 35: 335-341.

26. Thornhill MH, Wellicome SM, Mahiouz DL, Lanchbury JSS, Kyan-Aung U, Haskard DO. Tumor necrosis factor combines with IL-4 and IFN $\gamma$ to selectively enhance endothelial cell adhesive- 
ness for T cells. The contribution of vascular cell adhesion molecule-1 -dependent and independent binding mechanisms. J Immunol 1991; 146: 592-598.

27. Davis LG, Dibner MD, Battey JF. eds. Guanidine Isothiocyanate preparation of total RNA. In: Basic Methods in molecular biology. New York, Elsevier, 1986; 130-135.

28. Korn SH, Wouters EFM, Wesseling G, Arends J-W, Thunnissen FBJM. In vitro and in vivo modulation of $\alpha$ and $B$ glucocorticoid receptor mRNA in human bronchial epithelium. Am J Respir Crit Care Med 1997; 155: 1117-1122.

29. Schouten HJA. Klinische statistiek, een practische inleiding in methodologie en analyse. Houten, Bohn, Stafleu, Van Loghum, 1995; 73.

30. Endres S, Fülle HJ, Sinha B, Stoll D, Dinarello CA, Gerzer R, Weber PC. Cyclic nucleotides differentially regulate the synthesis of tumour necrosis factor- $\alpha$ and interleukin $1 B$ by human mononuclear cells. Immunology 1991; 72: 56-60.

31. Waage A, Sørensen M, Størdal B. Differential effect of oxpentifylline in tumour necrosis factor- $\alpha$ and interleukin- 6 production. Lancet 1990; 335: 543.

32. Schade FU, Schudt C. The specific type III and IV phosphodiesterase inhibitor zardaverine suppresses formation of tumor necrosis factor by macrophages. Eur I Pharmacol 1993; 230: 9-14.

33. Kambayashi T, Jacob CO, Zhou D, Mazurek N, Fong M, Strassmann G. Cyclic nucleotide phosphodiesterase type IV participates in the regulation of IL-10 and in the subsequent inhibition of TNF- $\alpha$ and IL- 6 release by endotoxin-stimulated macrophages. J Immunol 1995; 155 : 4909-4916.

34. Kunkel SL, Wiggins SW, Chensue SW, Larrick J. Regulation of macrophage tumor necrosis factor production by prostaglandin E2. Biochem Biophys Res Commun 1986; 137: 404-410.

35. Renz H, Gong J-H, Schmidt A, Nain M, Gemsa D. Release of Tumor necrosis factor- $\alpha$ from macrophages: Enhancement and suppression are dose-dependently regulated by prostaglandin $E_{2}$ and cyclic nucleotides. J Immunol 1988; 141: 2388-2393.

36. Katakami Y, Nakao Y, Koizumi T, Katakami N, Ogawa R, Fujita T. Regulation of Tumour necrosis factor production by mouse peritoneal macrophages: the role of cellular cyclic AMP. Immunol 1988; 64: 719-724.

37. Sinha B, Semmler J, Eisenhut T, Eigler A, Endres S. Enhanced tumor necrosis factor suppression and cyclic adenosine monophosphate accumulation by combination of phosphodiesterase inhibitors and prostanoids. Eur J Immunol 1995; 25: 147-153.

38. Strassmann G, Patil-Koota V, Finkelman F, Fong M, Kambayashi T. Evidence for the involvement of Interleukin 10 in the differential deactivation of murine peritoneal macrophages by prostaglandin $\mathrm{E}_{2}$. J Exp Med 1994; 180: 2365-2370.

39. Platzer C, Meisel Ch, Vogt K, Platzer M, Volk H-D. Upregulation of monocytic IL-10 by tumor necrosis factor- $\alpha$ and CAMP elevating drugs. Inter Immunol 1995; 7: 517-523.

40. Taffet S, Singhel KJ, Overholtzer JF, Shurtleff SA. Regulation of tumor necrosis factor expression in a macrophage-like cell line by lipopolysaccharide and cyclic AMP. Cell Immunol 1989; 120: 291-300.

41. Engelberts I, von Asmuth EJA, van der Linden CJ, Buurman W.A. The interrelation between TNF, IL-6 and PAF secretion induced by LPS in an in vivo and in vitro murine model. Lymphokine Cytokine Res 1991; 10: 127-131.

42. Strieter RM, Remick DG, Lynch JP, Genord M, Raiford C, Spengler R, Kunkel SL. Differential regulation of Tumor Necrosis Factor- $\alpha$ in human alveolar macrophages and peripheral blood monocytes: a cellular and molecular analysis. Am J Respir Cell Mol Biol 1989; 1: 57-63.

43. Tenor H, Staniciu L, Hatzelmann A, Shute JK, Rabe KF, Djukanovic R, Wendel A, Church MK, Schudt $C$. Analysis of phosphodiesterase isoenzyme pattern in human inflammatory cells. Eur Respir J 1993; 6: 320s.

44. Balibrea JL, Arias-Díaz JA, García C, Vara E. Effect of pentoxifylline and somatostatin on Tumour necrosis factor production by human pulmonary macrophages. Circ Shock 1994; 43: $51-56$. 
45. Bereta M, Bereta J, Georgoff I, Coffman FD, Cohen S, Cohen MC. Methylxanthines and calcium-mobilizing agents inhibit the expression of cytokine-inducible nitric oxide synthase and vascular cell adhesion molecule-1 in murine microvascular endothelial cells. Exp Cell Res 1994; 212: 230-242.

46. Pober JS, Slowik MR, De Luca LG, Ritchie AJ. Elevated cyclic AMP inhibits endothelial cell synthesis and expression of TNF-induced endothelial leucocyte adhesion molecule- 1 and vascular cell adhesion molecule-1, but not intercellular adhesion molecule-1. J Immunol 1993; 150: 5114-5123.

47. Leeuwenberg JFM, Dentener MA, Buurman WA. Lipopolysaccharide LPS-mediated soluble TNF-receptor release and TNF receptor expression by monocytes. Role of CD14, LPS binding protein, and Bactericidal/Permeability-increasing protein. J Immunol 1994; 152: 5070-5076.

48. Nicod LP, Galve-De-Rochemonteix B, Dayer JM. Modulation of IL-1 receptor antagonist and TNF-soluble receptors produced by alveolar macrophages and blood monocytes. Ann N Y Acad Sci 1994; 725: 323-330.

49. Bemelmans MHA, Gouma DJ, Buurman WA. Influence of nephrectomy on tumor necrosis factor clearance in a murine model. J Immunol 1993; 150: 2007-2017.

50. Engelberts I, Möller A, Leeuwenberg JFM, Van der Linden CJ, Buurman WA. Administration of Tumor necrosis factor $\alpha(\mathrm{TNF} \alpha)$ inhibitors after exposure to TNF $\alpha$ prevents development of the maximal biologial effect: an argument for clinical treatment with TNF $\alpha$ inhibitors. J Surg Res 1992; 53: 510-514.

51. Lagente V, Moodley I, Perrin S, Mottin G, Junien J-L. Effect of isozyme-selective phosphodiesterase inhibitors on eosinophil infiltration in the guinea pig lung. Eur J Pharmacol 1994; 255: 253-256.

52. Santing RE, Olymulder CG, Van der Molen K, Meurs H, Zaagsma J. Phosphodiesterase inhibitors reduce bronchial hyperreactivity and airway inflammation in unrestrained guinea pigs. Eur J Pharmacol 1995; 275: 75-82.

53. Lagente V, Pruniaux M-P, Junien J-L, Moodley I. Modulation of cytokine-induced infiltration by phosphodiesterase inhibitors. Am J Respir Crit Care Med 1995; 151: 1720-1724.

54. Kips JC, Tavernier JH, Peleman RA, Joos GF, Pauwels RA. Effect of theophylline on endotoxin and tumor necrosis factor induced airway changes in an in vivo model. Int Arch Allergy Immunol 1992; 99: 478-481.

55. Evans DJ, Taylor DA, Zetterstrom O, Chung KF, O'Connor BJ, Barnes PJ. A comparison of low-dose inhaled budenoside plus theophylline and high-dose inhaled budenoside for moderate asthma. N Eng/ J Med 1997; 337: 1412-1418.

56. Sinha B, Semmler J, Eisenhut T, Eigler A, Endres S. Enhanced Tumor necrosis factor suppression and cyclic adenosine monophosphate accumulation by combination of phosphodiesterase inhibitors and prostanoids. Eur J Immunol 1995; 25: 147-153.

57. Polson JB, Krzanowski JJ, Goldman AL, Szentivanyi A. Inhibition of human pulmonary phosphodiesterase activity by therapeutic levels of theophylline. Clin Exp Pharmacol Physiol 1978; 5: 535-539.

58. Chan SC, Hanifin JM. Differential inhibitor effects on cyclic adenosine monophosphate-phosphodiesterase isoforms in atopic and normal leucocytes. J Lab Clin Med 1993; 121: 44-51.

59. Estenne M, Yernault J-C, De Troyer A. Effects of parenteral aminophylline on lung mechanics in normal human. Am Rev Respir Dis 1980; 121: 967-971. 



\title{
Salmeterol and salbutamol decrease $\mathrm{TNF} \alpha$ release in human monocytes
}

\author{
HJ Pennings, MA Dentener, SH Korn, FBJM Thunissen", \\ WA Buurman "., EFM Wouters. \\ From the Department of Pulmonology and Pathology", \\ University Hospital Maastricht and Department of Surgery ".', \\ Maastricht University, The Netherlands.
}

submitted 


\section{SUMMARY}

Long-acting $\beta_{2}$-adrenoceptor agonists improve asthma-control and pulmonary function. Aim of the present study was to analyse effects of salmeterol and salbutamol, respectively a long-and short-acting $\beta_{2}$-adrenoceptor agonist, on the release of pro-inflammatory cytokines in human monocytes in vitro. Pro-inflammatory cytokines, like TNF $\alpha$, are involved in both asthmatic inflammation and induction of bronchial hyperresponsiveness.

Human blood monocytes of healthy volunteers were isolated and incubated with different concentrations of salbutamol $\left(10^{-10}-10^{-4} \mathrm{M}\right)$ and salmeterol $\left(10^{-10}-10^{-6}\right.$ M). After overnight incubation with LPS (0-1 $\left.\mu \mathrm{g} \cdot \mathrm{mL}^{-1}\right)$, TNF $\alpha$-, IL-6-, IL8- and IL-10-release was determined in supernatant by specific ELISA.

The study shows that both salmeterol $(n=8)$ and salbutamol $(n=9)$ significantly inhibited TNF $\alpha$ release (maximum inhibition respectively (mean \pm SEM) $47 \pm$ $8 \%$ and $46 \pm 5 \%, \mathrm{p}<0.03$ ), and a trend in inhibition of IL- 6 release was observed. In contrast, salbutamol and salmeterol increased IL-10 release in LPS-stimulated monocytes $\left(1 \mu \mathrm{g} \cdot \mathrm{mL}^{-1}\right) \quad(\mathrm{n}=7)$. Evidence for the primary involvement of the $\beta$-adrenoreceptor was demonstrated by the complete reversal of the inhibitory effects of salbutamol and salmeterol $\left(10^{-6} \mathrm{M}\right)$ on TNF $\alpha$ release by coincubation with propranolol $\left(10^{-4} \mathrm{M}\right)(\mathrm{n}=4)$. mRNA-analysis showed that both salmeterol and salbutamol $\left(10^{-6} \mathrm{M}\right)$ inhibited LPS-induced TNF $\alpha$-mRNA accumulation (inhibition respectively (mean \pm SEM) $73 \pm 5 \%$ and $64 \pm 2 \%$ ) and IL-6 mRNA accumulation (respectively $42 \pm 9 \%$ and $37 \pm 12 \%$ ).

In conclusion, salmeterol and salbutamol decreased pro-inflammatory cytokine release and inhibited accumulation of mRNA encoding for TNF $\alpha$ and IL-6 in LPS-stimulated monocytes in vitro. Observations from the present study may explain part of the immunomodulatory effects of long-acting $\beta_{2}$-adrenoceptor agonists in vivo.

\section{INTRODUCTION}

Long-acting $\beta_{2}$-agonists, like salmeterol, provide better asthma control and pulmonary function improvement than short-acting $\beta_{2}$-sympaticomimetic drugs, like salbutamol [1]. Besides bronchodilatory effects, salmeterol has been demonstrated to have antiinflammatory effects [2], although in some respects this has also been observed for short-acting $\beta_{2}$-agonists. Salbutamol has been shown to inhibit histamine release in human lung mast cells [3] and to reduce the early and late asthmatic response [4]. Salmeterol, which possesses more than fifteen times the potency of salbutamol on $\beta_{2}$-adrenoceptor activation in airway smooth muscle [5], inhibits mediator release in mast cells, eosinophils, neutrophils and alveolar 
macrophages in vitro [5]. Furthermore, salmeterol has been shown to inhibit mediator release in both passively sensitized human lung [6] and in segmental allergen challenge [7] and to protect against the allergen-induced late asthmatic response (LAR) in patients $[8,9]$. In asthmatic patients, salmeterol also protected against non-specific bronchial hyperresponsiveness, as assessed by distilled water bronchoprovocation, independent of the bronchodilatory effects induced by salmeterol [10]. Despite the proven antiinflammatory effects of salmeterol in both in vitro and acute broncho-provocation experiments, clinical studies evaluating possible anti-inflammatory effects of salmeterol are less unequivocal in this point. Although long-term use of salmeterol did not result in detectable changes in chronic asthmatic airway inflammation as evaluated in both bronchial biopsies [11] and bronchoalveolar lavage (BAL) [12], the addition of long-acting $\beta_{2}$-agonists to inhaled corticosteroid therapy was shown to result in better control of symptoms and improvement in PEFR in asthmatic patients $[13,141$. These observations suggest that long-acting $\beta_{2}$-agonists may influence inflammation in vivo. This hypothesis is supported by data from studies with other cAMP-elevating drugs (like theophylline and $\mathrm{PGE}_{2}$ ), which have been shown to inhibit the release of TNF $\alpha$ in vitro $[15,16,17]$. TNF $\alpha$, a pro-inflammatory cytokine, has been shown to play an important role in asthmatic inflammation. TNF $\alpha$ induces the release of inflammatory mediators [18] and enhances the expression of adhesion molecules on endothelial cells, which represents an important step necessary for tissue infiltration of inflammatory cells. In addition, TNF $\alpha$ has been shown to induce bronchial hyperresponsiveness $[18,19,20]$.

Aim of the present study was to evaluate the effect of salmeterol and salbutamol on the release of proinflammatory cytokines (TNF $\alpha$, Interleukin (IL)-6 and IL-8) and on IL-10, an immuno-regulatory cytokine, in lipopolysaccharide (LPS)-stimulated human monocytes in vitro. In the present study, peripheral blood monocytes are used since they can easily be obtained and can be regarded as progenitor cells of airway macrophages, which are involved in the asthmatic inflammation. The present study demonstrates that salmeterol and salbutamol inhibited LPSinduced monocyte-derived TNF $\alpha$, both at the level of mRNA as well as at protein levels in supernatant. Salmeterol and salbutamol also decreased LPS-induced IL-6 mRNA accumulation, whereas effects on IL-6 protein levels in supernatant were smaller. In addition, it was shown that salmeterol and salbutamol increased IL-10 release at the highest concentration of LPS. 


\section{MATERIAL AND METHODS}

\section{Reagents}

LPS (from Escherichia Coli, serotype 055: LB5) was obtained from Sigma Chemicals, Inc. (St. Louis, Mo). Recombinant human (rh) TNF $\alpha$ was kindly provided by BASF/Knoll (Ludwigshafen, Germany); rhIL-6 was provided by W. Sebald (Würzburg, Germany); rhIL-8 was provided by I. Lindley (Vienna, Austria); rhIL-10 and HB11677 were kindly provided by Van de Waal Malefyt (Palo Alto, CA). RPMI-1640 was obtained from Gibco, Europe (Paisley, Scotland). Bovine calf serum (BCS), obtained from Hyclone (Logan, UT), was heat-inactivated for $30 \mathrm{~min}$ at $56^{\circ} \mathrm{C}$ and stored at $4^{\circ} \mathrm{C}$. Salbutamol and Salmeterol were a kind gift from Glaxo-Wellcome BV, the Netherlands. Propranolol was obtained from ICIpharma.

GTC-solution consisted of $4 \mathrm{mM}$ guanidinium isothiocyanate, $25 \mathrm{mM}$ sodium acetate, $118 \mathrm{mM}$ 2-mercaptoethanol, $18 \mathrm{mM} \mathrm{N}$-lauroylsarcosine; CsCl-solution consisted of $5.7 \mathrm{M}$ caesiumchloride, $4 \mathrm{Mm}$ tetrasodiumsalt-dihydrat $\mathrm{pH} 8.0$; HES solution: $10 \mathrm{mM}$ HEPES $\mathrm{pH} 7.4,5 \mathrm{mM}$ tetrasodiumsaltdihydrat, $\mathrm{pH} 7.5$, $0.1 \%$ sodium dodecyl sulfate; $10^{*}$ MPS: $200 \mathrm{mM} 3$-morpholinopropane sulfonic acid, $80 \mathrm{mM}$ sodium acetate and $10 \mathrm{mM}$ tetrasodiumsaltdihydrat; $20^{*}$ SSC: $3 \mathrm{M}$ sodium chloride, $0.33 \mathrm{M}$ sodium citrate.

Probes: the TNF $\alpha$-probe, $0.615 \mathrm{kd} \mathrm{EcoR1-Cla} \mathrm{fragment} \mathrm{in} \mathrm{plasmid} \mathrm{pMG199,}$ was kindly provided by M. Robinson, Celltech (Slough, UK). Il-6 probe, $0.3 \mathrm{~kb}$ HIII-EcoR1 fragment in bluescribe M13, was provided by L. Aarden, CLB (Amsterdam, The Netherlands).

\section{Preparation of solutions of salbutamol and salmeterol}

Salbutamol $\left(\mathrm{C}_{13} \mathrm{H}_{21} \mathrm{NO}_{3}\right.$, MW 239.4) and salmeterol $\left(\mathrm{C}_{25} \mathrm{H}_{3} \mathrm{NO}_{4}\right.$, MW 415.6) were obtained in micronized form. Solutions of salbutamol and salmeterol were either feshly prepared or diluted from stock solutions $\left(10^{-3} \mathrm{M}\right)$. Salbutamol was diluted in sterile bidest. Salmeterol, due to its low solubility $(0.13 \%$ at $\mathrm{pH} 6.8)$, was diluted in phosphate-buffered saline (PBS), acidified with glacial acetic acid, until a clear solution was obtained.

\section{Cell isolation and stimulation}

Buffy coats were kindly provided by the Red Cross Blood Bank Zuid-Limburg, Maastricht, The Netherlands. Blood was donated by healthy volunteers, after informed consent for research was obtained. Human monocytes were isolated from buffy coats, essentially according to the method described by Graziano et al.[21]. 
Briefly, mononuclear cell suspensions obtained after density gradient centrifugation on Lymphoprep (Nycomed, Oslo, Norway) were allowed to clump at low speed centrifugation at $4^{0} \mathrm{C}$. Cell clumps were separated by sedimentation through icecold BCS, resulting in cell suspensions consisting of more than $85 \%$ monocytes. Monocytes were resuspended in RPMI 1640 supplemented with 10\% BCS, $2 \mathrm{mMol} \mathrm{L}$-glutamine, $100 \mathrm{IU} / \mathrm{ml}$ penicillin and $100 \mu \mathrm{g} / \mathrm{ml}$ streptomycin, plated on 96-well, flat-bottom tissue culture plates (Costar) at $5.10^{5}$ cells.mL $^{-1}$ $\left(200 \mu \mathrm{l}\right.$ per well) and incubated at $37^{\circ} \mathrm{C}$. The cells were preincubated for $15 \mathrm{~min}$ with salbutamol $\left(10^{-10}-10^{-4} \mathrm{M}\right)$, salmeterol $\left(10^{-10}-10^{-6} \mathrm{M}\right)$ or control medium and, thereafter, stimulated overnight with different concentrations of LPS $(1,100$ and $1000 \mathrm{ng} \cdot \mathrm{mL}^{-1}$ ). Supernatants of cells were harvested (for analysis of TNF $\alpha$, IL-6, IL-8 and IL-10) and stored at $-70^{\circ} \mathrm{C}$ until determination. Each experiment was performed at least in quadriplicate. Interindividual differences were discarded by comparing the effects of salbutamol and salmeterol in monocytes of the same donor.

Viability of the cells, as measured by trypan blue exclusion, was not affected by any of the reagents used (viability above $90-95 \%$ ).

\section{CYTOKINE ASSAYS}

Cytokines in supernatant were determined using previously described sandwich ELISA's for TNF $\alpha$, IL-6, IL-8 and IL-10 [22,23,24]. In short, 96-well Immuno Maxisorp plates (Nunc, Roskilde, Denmark) were coated overnight at $4^{0} \mathrm{C}$ with cytokine specific murine mAb 61E71 (anti-TNF $\alpha$ ), 5E1 (anti-IL-6), HM5 (antiIL8) and HB1 1677 (rat anti-hIL10). Recombinant human TNF $\alpha$, IL-6, IL-8 and IL-10 were used as standards. Samples were added and incubated for 1 to $3 \mathrm{~h}$ at room temperature. Therafter, samples were incubated with polyclonal rabbit anti-human TNF $\alpha$, biotinylated polyclonal rabbit anti-hIL- 6 and anti-hIL-8, and biotinylated rat-anti-hIL-10 at room temperature for $1 \mathrm{~h}$, followed by $1 \mathrm{~h}$ incubation with peroxidase conjugated goat anti-rabbit IgG (Jackson, West Grove, PA) for TNF $\alpha$ and with peroxidase labeled streptavidin for IL-6, IL-8 and IL-10. Finally, 3,3',5,5'-tetramethylbenzidine (Kirkegaard \& Perry Laboratories, Inc., Gaitersburg, MD) was added as substrate. The reaction was stopped after $15 \mathrm{~min}$ with $1 \mathrm{M} \mathrm{H}_{2} \mathrm{SO}_{4}$ and photospectrometry was performed at $450 \mathrm{~nm}$. The lower detection limits of the ELISA's were $10 \mathrm{pg} / \mathrm{ml}$ for TNF $\alpha$, IL-6, IL- 8 and $20 \mathrm{pg} / \mathrm{ml}$ for IL-10. 


\section{Control-experiments with propranolol}

In order to establish the specificity of the results obtained with salbutamol and salmeterol, control-experiments with propranolol $\left(\mathrm{C}_{16} \mathrm{H}_{21} \mathrm{NO}_{2} \cdot \mathrm{HCL}, \mathrm{MW} 259.3\right)$, a non-specific $\beta$-antagonist, were performed. These experiments also served the purpose of ruling out the possibility that the presence of salbutamol or salmeterol interfered with the detection of cytokines in the ELISA. Cells were preincubated for $15 \mathrm{~min}$ with propranolol $\left(10^{-4} \mathrm{M}\right)$, coincubated with salbutamol or salmeterol $\left(10^{-6} \mathrm{M}\right)$ for $15 \mathrm{~min}$, and immediately thereafter stimulated with LPS. Propranolol in 1:100 excess has been shown in a previous study to block $\beta$-adrenergic effects completely [6].

\section{Isolation and determination of TNF $\alpha$ and IL-6 mRNA}

RNA was isolated from the mononuclear cell fraction of blood in order to prevent loss of monocytes during the procedure. Mononuclear cells $\left(30 \mathrm{~mL}\right.$ a $3 \times 10^{6}$ cells. $\mathrm{mL}^{-1}$ ) were preincubated for $15 \mathrm{~min}$ with either salbutamol or salmeterol $\left(10^{-6} \mathrm{M}\right)$ and, thereafter, stimulated for $3 \mathrm{~h}$ with LPS $\left(1 \mu \mathrm{g} \cdot \mathrm{mL}^{-1}\right)$. Subsequently, RNA was isolated from the cells as described by Davis et al.[25], using a $4 \mathrm{M}$ GTC-solution. The ultracentrifugation, northern blot analysis, hybridization (including GAPDH as control probe) and semiquantitative analysis was performed as described before [26]. mRNA expression of TNF $\alpha$ and IL-6 was determined relatively to the expression of the control gene GAPDH. The hybridization signals were analyzed semiquantitatively with a phosphor-imaging system (Molecular Dynamics, Sunnyvale, CA).

\section{STATISTICAL ANALYSIS}

All data are presented as mean \pm SEM. Cytokine release in each individual experiment represents the mean of at least four replicates. Since cytokine-release did not show a normal distribution, non-parametric tests were used for analysis. Differences between medications were analysed by Mann-Whitney $U$ test, whereas for differences within medication-groups Wilcoxon test for paired data was used. Differences were considered statistically significant at $\mathrm{p}<0.05$ (two-sided). The statistical package SPSS/PC+ (version 6.01 Windows, SPSS Inc., Chicago, IL) was used for analysis. 

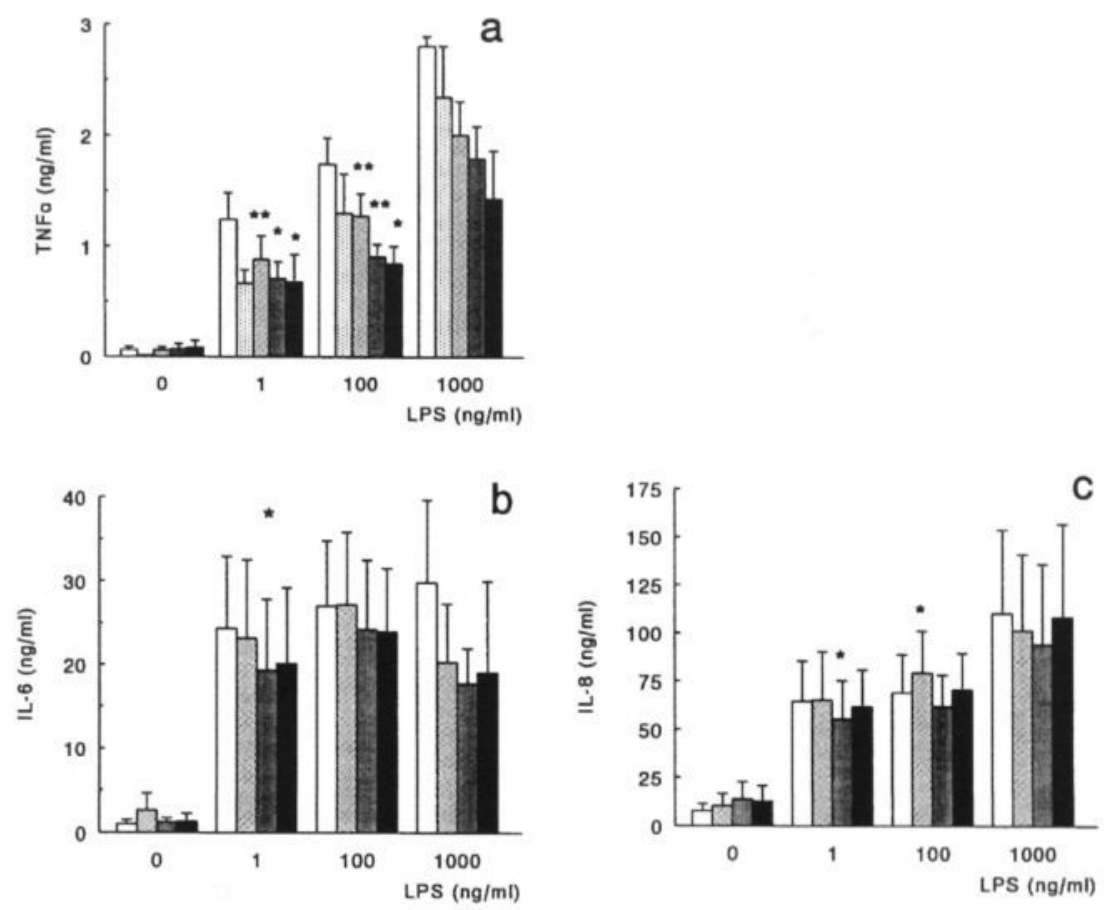

medium 10.10M

$10.8 \mathrm{M}$

$10.6 \mathrm{M}$

$10.4 \mathrm{M}$

Figure 1. Salbutamol significantly inhibits the release of TNF $\alpha$ and, to a lesser extent, of IL- 6 by LPS-stimulated monocytes. Monocytes were incubated with a concentration range of LPS (1-1000 $\mathrm{ng} . \mathrm{mL}^{-1}$ ) in the absence (open bar) or presence of $10^{-10}, 10^{-6}, 10^{-6}$ and $10^{-4} \mathrm{M}$ salbutamol. After overnight incubation, the presence of a) TNF $\alpha$; b:) IL-6; and c:) IL-8 in supernatant was determined by specific ELISA. The mean \pm SEM of nine independent experiments are shown $\left({ }^{\star *} p<0.01,{ }^{\star} p<\right.$ 0.03). No changes were observed in IL-8 release.

\section{RESULTS}

Overnight stimulation of monocytes with LPS resulted in a dose-dependent increase in TNF $\alpha$, IL- 6 and IL-8 release. Incubation with salmeterol and salbutamol inhibited TNF $\alpha$ release in LPS-stimulated monocytes (p< 0.03) (Fig.1a+2a); although for salbutamol and LPS $1000 \mathrm{ng} \cdot \mathrm{mL}^{-1}$, significance was not reached $(\mathrm{p}=0.07)$. The experiments show a trend towards inhibition of IL- 6 release, however IL-6 release was only significantly inhibited with salbutamol $10^{-6} \mathrm{M}$ and LPS $1 \mathrm{ng} \cdot \mathrm{mL}^{-1}(\mathrm{p}=0.028)$ (Fig. 1b). As apparent in the figures, a large variability was 

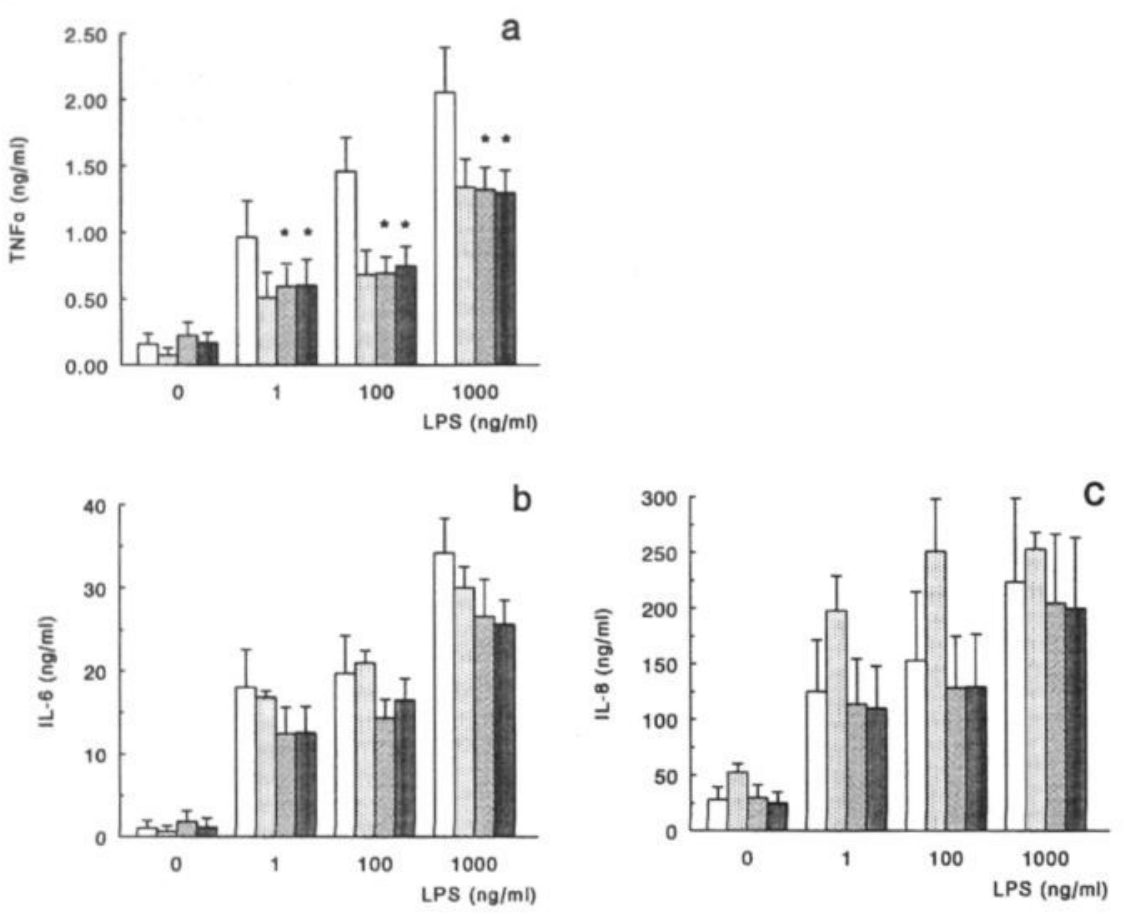

$\square$ medium $\square$ 10-10M $\square$ 10-8M ${ }^{10-6 \mathrm{M}}$

Figure 2. Salmeterol significantly inhibits TNF $\alpha$ release by LPS-stimulated monocytes. Monocytes were incubated with a concentration range of LPS (1-1000 ng. $\mathrm{mL}^{-1}$ ) in the absence (open bar) or presence of $10^{10}, 10^{-8}$ and $10^{6} \mathrm{M}$ salmeterol. After overnight incubation, a:) TNF $\alpha$; b:) IL-6; and c:) IL-8 were determined in supernatant by specific ELISA. The mean \pm SEM of eight independent experiments are shown $\left({ }^{\star} p<0.03\right)$. Although salmeterol seems to inhibit IL- 6 release, no significant changes were observed in IL- 6 nor IL-8 release.

observed in IL-6 and IL-8 release. In contrast, salmeterol and salbutamol did not affect LPS-induced IL-8 release (Fig. $1 \mathrm{c}+2 \mathrm{c}$ ).

When comparing the effects of salmeterol and salbutamol on TNF $\alpha$ release, salmeterol $\left(10^{-6} \mathrm{M}\right)$ inhibited TNF $\alpha$ release to a similar extent as salbutamol $\left(10^{-6}\right.$ M) (respectively $47 \pm 8 \%$ and $46 \pm 5 \%$ ) (Fig.3). The overall inhibitory effect of salbutamol on TNF $\alpha$ release was dose-dependent and maximum inhibition of $\mathrm{TNF} \alpha$ release $(57 \pm 7 \%)$ was observed with salbutamol $10^{-4} \mathrm{M}$ (Fig.1a). In contrast, salmeterol seemed to reach already maximum inhibition of TNF $\alpha$ release at concentrations as low as $10^{-10} \mathrm{M}$, although at low LPS levels $\left(1 \mathrm{ng} \cdot \mathrm{mL}^{-1}\right)$ a dose- 


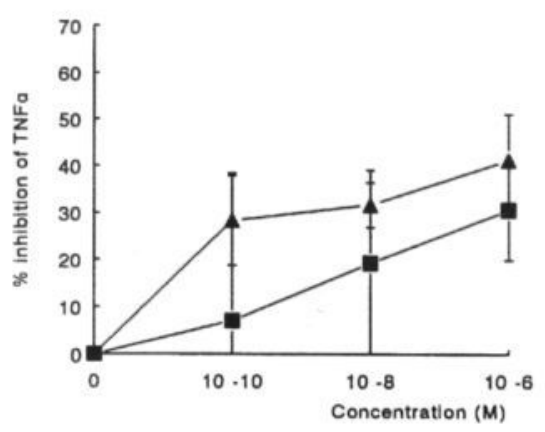

LPS $100 \mathrm{ng} / \mathrm{ml}$
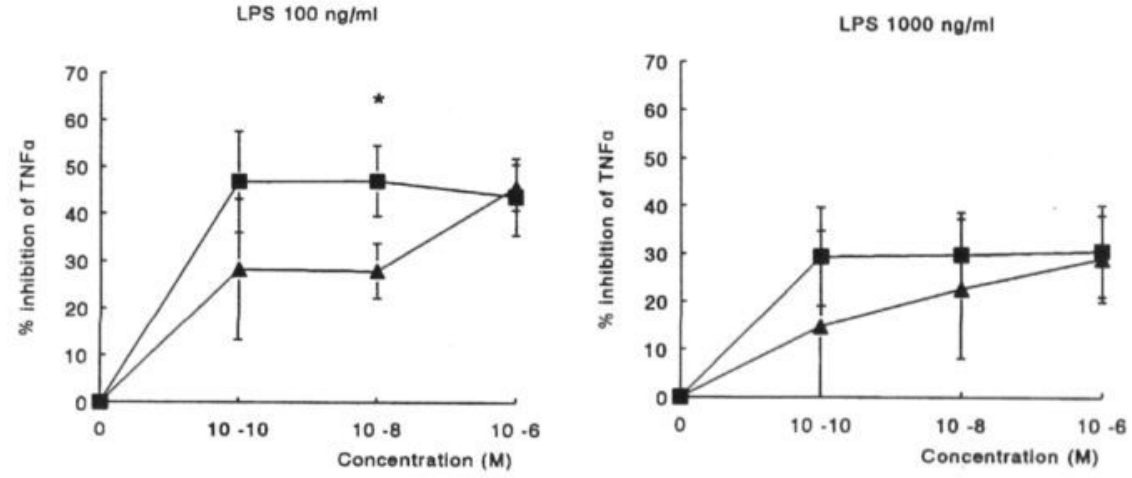

Figure 3. Comparison of the inhibitory effects of salbutamol and salmeterol on TNF $\alpha$-release by LPS stimulated monocytes. Inhibition is defined as ((cytokine-release in medium - cytokine-release in the presence of drug)/ cytokine-release in medium)) $\times 100 \%$. Salmeterol ([-m) and salbutamol $(\boldsymbol{\Delta}-\mathbf{\Delta})$ inhibited TNF $\alpha$, release to a similar extent (with the exception of salmeterol $10^{-6} \mathrm{M}$ and LPS $\left.100 \mathrm{ng} \cdot \mathrm{mL}^{-1}\left({ }^{*} \mathrm{p}=0.03\right)\right)$. Whereas for salbutamol a dose-dependent inhibition of TNF $\alpha$ was observed, salmeterol seemed to reach already maximum inhibition of TNF $\alpha$ at low concentrations, when stimulated with LPS 100-1000 $\mathrm{ng} \cdot \mathrm{mL}^{-1}$

dependent inhibition seemed to exist. Generally speaking, inhibitory effects of salmeterol and salbutamol were comparable (Fig.3). The maximum inhibitory effects of both $\beta_{2}$-agonists on TNF $\alpha$ release tended to be lower for the highest concentration of LPS.

In order to examine whether $\beta$-adrenergic receptors were involved in the cytokine-inhibition, induced by salmeterol and salbutamol, control experiments with the non-specific $\beta$-blocking drug propranolol were performed. Propranolol completely reversed the inhibitory effects of both salbutamol and salmeterol on 


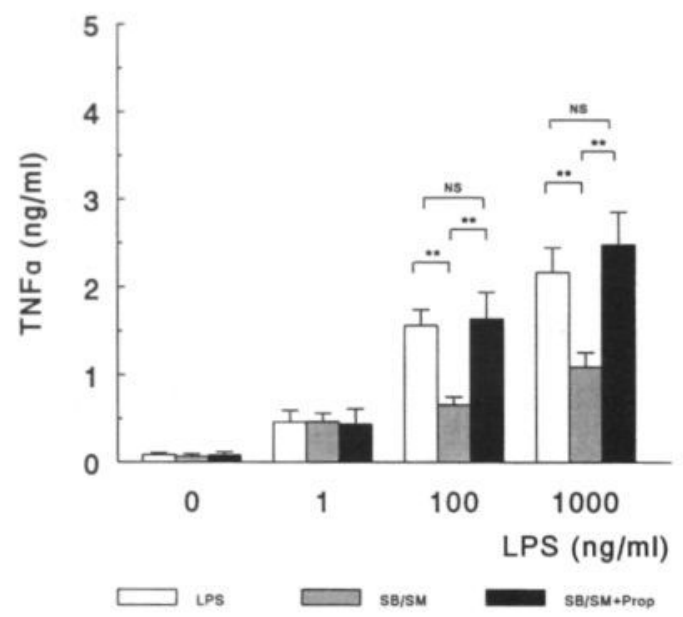

Figure 4. Propranolol, a non-selective $\beta$-adrenoceptor inhhibitor, completely reversed salbutamol- and salmeterolinduced inhibition of TNF $\alpha$ release. Monocytes were preincubated for $15 \mathrm{~min}$ with propranolol $\left(10^{-4} \mathrm{M}\right)$, followed by $15 \mathrm{~min}$ incubation with salbutamol $(n=3)$ / salmeterol ( $\left.10^{-6} M\right)(n=4)$ or control medium (open bar). Thereafter, cells were stimulated overnight with different concentrations of LPS. Since similar results were obtained for salbutamol and salmeterol, data are compiled ${ }^{\star \star} \mathrm{p}<$ 0.01 salbutamol/salmeterol $10^{-6} \mathrm{M}$ in comparison with medium control and in comparison with coincubation of salbutamol/salmeterol with propranolol $10^{-4} \mathrm{M}$ ).

LPS-induced TNF $\alpha$ release (Fig.4). This indicates that the observed inhibition of TNF $\alpha$ release resulted from an interaction with $\beta$-adrenoreceptors, and not merely from a possible interference of the $\beta_{2}$-adrenergic drugs with the detection of TNF $\alpha$ in the ELISA.

Additionally, we analysed pathways involved in the regulation of cytokinesynthesis. Since cAMP elevating drugs have been shown to inhibit TNF $\alpha$ release partially through the involvement of IL-10 [15], and since both salbutamol and salmeterol increase intracellular cAMP, the next set of experiments measured IL-10 in supernatant together with TNF $\alpha$ (Fig.5). LPS induced a dose-dependent increase in the release of both IL-10 and TNF $\alpha$. However, although salbutamol and salmeterol inhibited TNF $\alpha$ release at all concentrations of LPS tested 

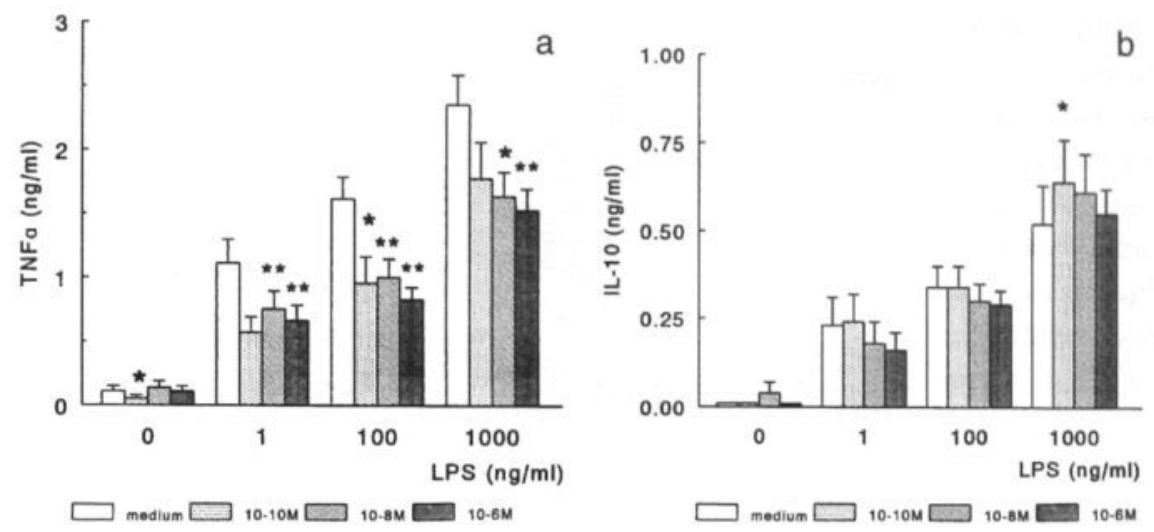

Figure 5 a-b. Changes in IL-10 do not correlate with changes in the release of TNF $\alpha$, induced by salbutamol and salmeterol. Presence of a:) TNF $\alpha$ and b:) IL-10 in supernatant of monocytes, incubated with different concentrations of salbutamol or salmeterol $\left(10^{-10} ; 10^{-8} ; 10^{-6} \mathrm{M}\right)$ and stimulated overnight with LPS (1-1000 ng. $\left.\mathrm{mL}^{-1}\right)(\mathrm{n}=7)$. Since for salbutamol and salmeterol similar results were obtained, data were compiled. Whereas salmeterol and salbutamol significantly inhibited TNF $\alpha$ release at all concentrations of LPS $\left({ }^{*} p<0.02,{ }^{* \star} p<0.01\right)$, an increased release of IL-10 is only observed at LPS $1 \mu \mathrm{g} \cdot \mathrm{mL}^{-1}$ in the presence of salbutamol/salmeterol $\left({ }^{\star} p<0.03\right)$. Data suggest that IL-10 is not involved in the inhibition of TNF $\alpha$ release at lower concentrations of LPS.

(Fig.5a), IL-10 release was only increased at the highest concentration of LPS. This observation suggests that at lower concentrations of LPS an IL-10independent pathway is involved in the salmeterol- and salbutamol-induced inhibition of TNF $\alpha$.

Since phosphodiesterase inhibitors, which also increase intracellular cAMP, have been shown to inhibit LPS induced TNF $\alpha$-mRNA accumulation in mononuclear cells $[16,17]$, the present study additionally established the effect of salmeterol and salbutamol on the levels of TNF $\alpha$ - and Il-6 mRNA expression. Analysis for IL-8 mRNA expression was not performed, since no changes were observed for IL-8 in supernatant.

Both salmeterol and salbutamol were shown to decrease LPS-induced $\mathrm{TNF} \alpha$-mRNA levels (inhibition (mean \pm SEM of 3 individual experiments) respectively $73 \pm 5 \%$ and $64 \pm 2 \%$ )(Fig.6). IL-6 mRNA accumulation was also decreased, although this effect was less pronounced (with salmeterol $42 \pm 9 \%$ and with salbutamol $37 \pm 12 \%$ (mean \pm SEM of 3 individual experiments). 


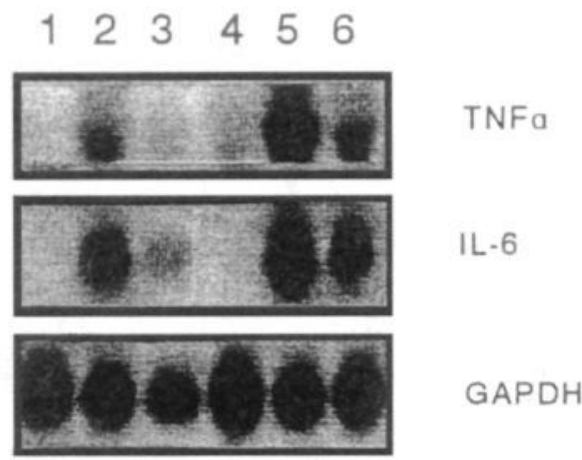

Figure 6. Northern-blot autoradiographs of TNF $\alpha$-, IL-6- and GAPDH-mRNA, induced by stimulating monocytes with LPS $1 \mu \mathrm{g} \cdot \mathrm{mL}^{-1}$ in the presence of either medium or salmeterol or salbutamol $10^{-6} \mathrm{M}$. Monocytes were stimulated for three $h$ in the presence of LPS and thereafter mRNA was isolated. The figure shows northern blots of one representive experiment (out of three). Lane 1: medium; lane 2: LPS; 3: LPS + salbutamol; lane 4: medium; lane 5: LPS; lane 6: LPS+salmeterol. Both salmeterol and salbutamol reduced LPS-stimulated TNF $\alpha$-mRNA accumulation (the inhibitory effect amounting respectively (mean \pm SEM) $73 \pm 5 \%$ and $64 \pm 2 \%$ ) and IL-6 mRNA (respectively for salmeterol (mean \pm SEM ) 42 $\pm 9 \%$ and salbutamol $37 \pm 12 \%$ ).

\section{DISCUSSION}

The present study shows that salmeterol and salbutamol decrease TNF $\alpha$ release in LPS-stimulated human monocytes. Involvement of the $\beta_{2}$-adreno-receptor in this immunomodulatory effect was demonstrated by the complete reversal of inhibition of TNF $\alpha$ release by the non-selective $\beta$-antagonist propranolol. Salmeterol and salbutamol were also shown to inhibit TNF $\alpha$ and IL- 6 mRNA accumulation in LPS-stimulated monocytes, although inhibitory effects on IL-6 mRNA accumulation were smaller. IL-10 was not involved in the $\beta_{2}$-agonist-induced downregulation of TNF $\alpha$, except for the highest concentrations of LPS.

TNF $\alpha$, a pro-inflammatory cytokine, has been shown to be involved in the pathogenesis of asthma $[18,19]$. Previously, theophylline and other phosphodiesteraseinhibitors, have been shown to inhibit TNF $\alpha$ release in monocytic cells, although concentrations necessary for this effect lay well above clinically acceptable levels 
$[16,17]$. In these studies, increased levels of cAMP were considered to be responsible for the observed effect on TNF $\alpha$ release. The present study observes that, in line with data from studies above, salbutamol and salmeterol, which also increase intracellular cAMP, inhibit TNF $\alpha$ release; however, salbutamol and salmeterol were found to decrease TNF $\alpha$ levels at pharmaceutical concentrations. Our data are supported by a previous study, which demonstrated that salmeterol and salbutamol inhibited TNF $\alpha$ release in a monocytic cell line [27]; although TNF $\alpha$-release was inhibited more than observed in the present study, differences in TNF $\alpha$ release between the two studies can be explained by differences in cell activation status either due to maturation effects or culture conditions.

Besides interference with TNF $\alpha$ production, cAMP has also been implicated in LPS-induced IL-10 synthesis [28] and IL-10 gene-activation [29]. Therefore, the present study also studied the presence of IL-10 in supernatant, since it has been shown that IL-10 is, at least partially, involved in the effect of cAMP-elevating agents on TNF $\alpha$. IL-10 is produced by Th2- and B-lymphocytes, mast cells and mononuclear phagocytes and has been shown to be involved in the autoregulatory pathway of cytokine release in monocytic cells $[15,30,31,32]$. IL-10 inhibits TNF $\alpha$-, IL-6- and IL-1 $\beta$ mRNA production both in LPS-stimulated monocytic cells [30,31] and human alveolar macrophages [32]. In the present study, IL-10 levels were evaluated after $20 \mathrm{~h}$ incubation, at which point in time IL-10 levels are nearly maximum [30,33]. De Waal et al. observed in monocytes that IL-10 inhibited release of TNF $\alpha$ more than IL-6, without affecting IL-8. The present study showed that IL-10 release was enhanced by salmeterol and salbutamol at maximum LPS concentrations, which is in accordance with observations with adenosine [34]. The trend of decreasing IL-10 levels by increasing concentrations of salbutamol/salmeterol per concentration of LPS may be explained by decreasing concentration of TNF $\alpha$ in supernatant, since TNF $\alpha$ itself has been shown to stimulate IL-10 release in monocytes, as part of the autoregulatory cycle of cytokine-synthesis [35]. The present study also demonstrated that TNF $\alpha$ release is markedly inhibited, even when IL-10 levels are not increased. These data are in line with data from studies with adenosine [34], $\mathrm{PGE}_{2}$ [15] and Rolipram [36], which demonstrated that IL-10 is only partially responsible for TNF $\alpha$ inhibition, since treatment with anti-IL-10 only partially reversed TNF $\alpha$-inhibition. This suggests that other pathways are involved in the inhibition of TNF $\alpha$. Data from the present study support this hypothesis. Whereas salbutamol was observed to inhibit TNF $\alpha$ release dose-dependently, salmeterol seemed to reach already maximum inhibition at low concentrations. A possible explanation may be that salmeterol induces higher levels of cAMP in comparison with salbutamol [37]. However, salmeterol in the present study maximally inhibited TNF $\alpha$ release at concentrations, which are not considered to be associated with high cAMP levels. 
Interestingly, the inhibitory effects of salmeterol on TNF $\alpha$ release, observed in the present study, closely resemble inhibitory effects of salmeterol on sulphopeptidoleukotriene-release in stimulated human lung mast cells [38]. Salmeterol was found to be an effective inhibitor in picomolar concentrations, whereas intracellular cAMP levels were not increased. Observations from the present study suggest the existence of cAMP-independent pathways of cytokinemodulation.

So far, few studies have demonstrated interference of cAMP-elevating drugs on LPS-induced IL-6 release. Adenosine, a mediator released during ischemia, was shown to inhibit both TNF $\alpha$ - and Il-6 release in LPS-stimulated monocytes [24]. More recently, a specific type IV phosphodiesterase-inhibitor was also shown to inhibit both TNF $\alpha$ and IL-6 release in LPS-stimulated macrophages [38]. Both studies observed that IL- 6 release was less affected than TNF $\alpha$ release. Observations in the present study show that, although salmeterol and salbutamol decreased LPS-induced IL-6 mRNA levels, only mild changes were detected in IL-6 protein levels in supernatant. This suggests the presence of post-transcriptional modulations.

In conclusion, this study demonstrated antiinflammatory effects of salmeterol and salbutamol, both on LPS-induced TNF $\alpha$ and IL-6 mRNA levels and on TNF $\alpha$ and IL-6 protein levels in supernatant of human monocytes. IL-10 release was enhanced by salmeterol and salbutamol at the highest LPS-concentration and may have exerted an additional (late) immunoregulatory role. Observations from the present study may serve to explain part of the inhibitory effects of $\beta_{2}$-adrenergic drugs on the late asthmatic response, which has been shown to involve the release of TNF $\alpha[9,18]$. Although salmeterol and salbutamol demonstrated immunomodulatory effects at therapeutic concentrations, inhaled corticosteroids still are the most powerful antiinflammatory drugs currently used. However, since corticosteroids and cAMP-elevating agents inhibit cytokine synthesis via separate pathways [39], this may explain why clinical studies, using the combination of inhaled corticosteroids with long-acting $\beta_{2}$-adrenoceptor agonists, have observed an improved control of asthmatic disease [13,14]. Modulating pro-inflammatory cytokine-synthesis may be one of mechanisms through which long-acting $\beta_{2}$-agonists may influence asthmatic inflammation.

\section{REFERENCES}

1. Pearlman DS, Chervinsky P, LaForce G, Seltzer JM, Southern DL, Kemp JP, Dockhorn RJ, Grossman J, Liddle RF, Yancey SW, Cocchetto DM, Alexander WJ, Van As A. A comparison of salmeterol with albuterol in the treatment of mild-to-moderate asthma. N Engl J Med 1992; 327: $1420-1425$. 
2. Löfdahl CG, Chung KF. Long-acting $B_{2}$-adrenoceptor agonists: a new perspective in the treatment of asthma. Eur Respir J 1991; 4: 218-226.

3. Nials AT, Ball DI, Butchers PR, Coleman RA, Humbles AA, Johnson M, Vardey CJ. Formoterol on airway smooth muscle and human lung mast cells: a comparison with salbutamol and salmeterol. Eur J Pharmacol 1994; 251: 127-135.

4. Twentyman OP, Finnerty JP, Holgate ST. The inhibitory effect of nebulized albuterol on the early and late asthmatic reactions and increase in airway hyperresponsiveness provoked by inhaled allergen in asthma. Am Rev Respir Dis 1991; 144: 782-787.

5. Johnson M, Butchers PR, Coleman RA, Nials AT, Strong P, Sumner MJ, Vardey CJ, Whelan CJ. The pharmacology of salmeterol. Life Sci 1993; 52: 2131-2143.

6. Butchers PR, Vardey CJ, Johnson M. Salmeterol: a potent and long-acting inhibitor of inflammatory mediator release from human lung. $\mathrm{Br} J$ Pharmacol 1991; 104: 672-676.

7. Murray JJ, Hagaman DD, Dworski R, Keane B, Sheller JR. Inhibition by salmeterol and beclomethasone of late phase response to segmental antigen challenge in asthmatics. Am J Respir Crit Care Med 1998; 157: A872.

8. Twentyman OP, Finnerty JP, Harris A, Palmer J, Holgate ST. Protection against allergen-induced asthma by salmeterol. Lancet 1990; 336: 1338-1342.

9. Pedersen $B$, Dahl $R$, Larsen $B B$, Venge $P$. The effect of salmeterol on the early- and late-phase reaction to bronchial allergen and postchallenge variation in bronchial reactivity, blood eosinophils, serum eosinophil cationic protein, and serum eosinophil protein X. Allergy 1993; 48: 377-382.

10. Bootsma GP, Dekhuijzen PNR, Festen J, Lammers J-WJ, Mulder PGH, Van Herwaarden CLA. Sustained protection against distilled water provocation by a single dose of salmeterol in patients with asthma. Eur Respir J 1997; 10: 2230-2236.

11. Roberts JA, Bradding P, Walls AF, Britten KM, Wilson S, Holgate ST, Howarth PH. The influence of salmeterol xinafoate on mucosal inflammation in asthma. Am Rev Respir Dis 1992; 145; A418.

12. Gardiner PV, Ward C, Booth H, Allison A, Hendrick DJ, Walters EH. Effect of eight weeks of treatment with salmeterol on bronchoalveolar lavage inflammatory indices in asthmatics. Am J Respir Crit Care Med 1994; 150: 1006-1011.

13. Woolcock A, Lundbeck B, Ringdal N, Jacques LA. Comparison of addition of salmeterol to inhaled steroids with doubling of the dose of inhaled steroids. Am J Respir Crit Care Med 1996; 153: $1481-1488$.

14. Greening AP, Ind PW, Northfield M, Shaw G. Added salmeterol versus higher-dose corticosteroids in asthma patients with symptoms on existing inhaled corticosteroid. Lancet 1994; 344: 219-224.

15. Strassmann G, Patil-Koota V, Finkelman F, Fong M, Kambayashi T. Evidence for the involvement of Interleukin 10 in the differential deactivation of murine peritoneal macrophages by Prostaglandin $\mathrm{E}_{2}$. J Exp Med 1994; 180: 2365-2370.

16. Strieter RM, Remick DG, Ward PA, Spengler RN, Lynch JP, Larrick J, Kunkel SL. Cellular and molecular regulation of tumor necrosis factor-alpha production by pentoxifylline. Biochem Biophys Res Commun 1988; 155: 1230-1236.

17. Endres S, Fülle H-J, Sinha B, Stoll D, Dinarello CA, Gerzer R, Weber PC. Cyclic nucleotides differentially regulate the synthesis of tumour necrosis factor- $\alpha$ and interleukin-1B by human mononuclear cells. Immunology 1991; 72: 56-60.

18. Kips JC, Tavernier JH, Joos GF, Peleman RA, Pauwels RA. The potential role of tumour necrosis factor- $\alpha$ in asthma. Clin Exp Allergy 1993; 23: 247-250.

19. Thomas PS, Yates DH, Barnes PJ. Tumor necrosis factor- $\alpha$ increases airway responsiveness and sputum neutrophilia in normal human subjects. Am J Respir Crit Care Med 1995; 152: 76-80.

20. Pennings HJ, Kramer K, Bast A, Buurman WA, Wouters EFM. Tumor necrosis factor- $\alpha$ induces hyperreactivity in tracheal smooth muscle of the guinea pig in vitro. Eur Respir J 1998; 12: 45-49.

21. Graziano RF, Fanger MW. FcgRI and FcgRII on monocytes and granulocytes are cytotoxic trigger molecules for tumor cells. J Immunol 1987; 139: 3536-3541. 
22. Engelberts I, Möller A, Schoen GJM, Van Der Linden CJ, Buurman WA. Evaluation of measurement of human TNF in plasma by ELISA. Lymphokine Cytokine Res 1991; 10: 69-76.

23. Dentener MA, Bazil V, Von Asmuth EJU, Ceska M, Buurman WA. Involvement of CD14 in lipopolysaccharide-induced tumor necrosis factor- $\alpha$, IL- 6 and IL- 8 release by human monocytes and alveolar macrophages. J Immunol 1993; 150: 2885-2891.

24. Bouma MG, Stad RK, Van Den Wildenberg FAJM, Buurman WA. Differential regulatory effects of adenosine on cytokine release by activated human monocytes. J Immunol 1994; 153: 4159-4168.

25. Davis LG, Dibner MD, Battey JF. eds. Guanidine Isothiocyanate preparation of total RNA. In: Basic Methods in molecular biology. New York, Elsevier, 1986; p 130-135.

26. Korn SH, Wouters EFM, Wesseling G, Arends J-W, Thunnissen FBJM. In vitro and in vivo modulation of $\alpha$ and $B$ glucocorticoid receptor mRNA in human bronchial epithelium. Am J Respir Crit Care Med 1997; 155: 1117-1122.

27. Sekut L, Champion BR, Page K, Menius JA, Conolly KM. Anti-inflammatory activity of salmeterol: down-regulation of cytokine production. Clin Exp Immunol 1995; 99: 461-466.

28. Meisel C, Vogt K, Platzer C, Randow F, Liebenthal C, Volk H-D. Differential regulation of monocytic tumor necrosis factor- $\alpha$ and interleukin-10 expression. Eur J Immunol 1996; 26: $1580-1586$.

29. Platzer C, Meisel Ch, Vogt K, Platzer M, Volk H-D. Upregulation of monocytic IL-10 by tumor necrosis factor- $\alpha$ and cAMP elevating drugs. Inter Immunol 1995; 7: 517-523.

30. De Waal Malefyt R, Abrams J, Bennet B, Figdor CG, De Vries JE. Interleukin 10(IL-10) inhibits cytokine synthesis by human monocytes: an autoregulatory role of IL-10 produced by monocytes. J Exp Med 1991; 174:1209-1220.

31. Wang P, Wu P, Siegel MI, Egan RW, Billah MM. IL-10 inhibits transcription of cytokine genes in human peripheral blood mononuclear cells. J Immunol 1994; 153: 811-816.

32. Armstrong L, Jordan N, Millar A. Interleukin 10 (IL-10) regulation of tumour necrosis factor $\alpha($ TNF- $\alpha)$ from human alveolar macrophages and peripheral blood monocytes. Thorax 1996; 51: 143-149.

33. Matthias J, Lim S, Seybold J, Jose P, Robichaud A, O'Connor B, Barnes PJ, Chung KF. Inhaled corticosteroids increase interleukin-10 but reduce macrophage inflammatory protein-1 $\alpha$, granulocyte-macrophage colony-stimulating factor, and interferon- $\gamma$ release from alveolar macrophages in asthma. Am J Respir Crit Care Med 1998; 157: 256-262.

34. Le Moine O, Stordeur P, Schandené L, Maerchant A, de Groote D, Goldman M, Devière J. Adenosine enhances IL-10 secretion by human monocytes. I Immunol 1996; 156: 4408-4414.

35. Platzer C, Meisel Ch, Vogt K, Platzer M, Volk H-D. Upregulation of monocytic IL-10 by tumor necrosis factor- $\alpha$ and cAMP elevating drugs. Inter Immunol 1995; 7: 517-523.

36. Kambayashi T, Jacob CO, Zhou D, Mazurek N, Fong M, Strassmann G. Cyclic nucleotide phosphodiesterase type IV participates in the regulation of IL-10 and in the subsequent inhibition of TNF- $\alpha$ and IL- 6 release by endotoxin-stimulated macrophages. J Immunol 1995; 155: 4909-4916.

37. Ellis KE, Mistry R, Boyle JP, Chaliss RAJ. Correlation of cyclic AMP accumulation and relaxant actions of salmeterol and salbutamol in bovine tracheal smooth muscle. Br J Pharmacol 1995; 116: 2510-2516.

38. Chong LK, Cooper E, Vardey CJ, Peachell PT. Salmeterol inhibition of mediator release from human lung mast cells by $B$-adrenoceptor-dependent and independent mechanisms. $\mathrm{Br} J$ Pharmacol 1998; 123: 1009-1015.

39. Han J, Thompson P, Beutler B. Dexamethasone and pentoxifylline inhibit endotoxin-induced cachectin/tumor necrosis factor synthesis at separate points in the signaling pathway. J Exp Med 1990; 172: 391-394. 


\section{CHAPTER 6}

\section{Effect of inhaled beclomethasone dipropionate on isocapnic hyperventilation with cold air in asthmatics, measured with forced oscillation technique}

H.J. Pennings, E.F.M. Wouters.

From the Department of Pulmonology,

University Hospital Maastricht, The Netherlands. 


\section{ABSTRACT}

Isocapnic hyperventilation with cold air (IHCA) is a reliable technique for assessing indirect bronchial hyperresponsiveness in patients with asthma. Impedance measurement of the respiratory system by the forced pseudo-random noise oscillation technique is a sensitive technique to assess changes in bronchial tone after IHCA.

The aim of the study was to evaluate the effect of six weeks of treatment with beclomethasone dipropionate (BDP) $1000 \mu$ g.day ${ }^{1}$ on isocapnic hyperventilation with cold air in asthmatic patients measured with both forced oscillation technique and flow-volume recordings. Forty patients with mild asthma were included in this double-blind, placebo-controlled parallel-group study. Stratification on the basis of sex was performed to overcome differences in airway diameter. At entry and every 2 weeks during the treatment period, IHCA was performed and patient-diaries were evaluated. Characteristic changes in forced oscillation parameters after IHCA were observed in all patients. After 6 weeks of treatment, BDP-treated patients showed statistically significant differences in impedance measurements after IHCA, manifested by significant attenuation of resistance at 8 $\mathrm{Hz}(\mathrm{p}<0.01)$, slope of the frequency-resistance curve ( $<<0.01)$, reactance at $8 \mathrm{~Hz}$ $(\mathrm{p}=0.01)$ and resonant frequency $\left(f_{0}\right)(\mathrm{p}<0.02)$. Flow-volume recordings showed only a statistically significant change in the decrease of IVC $(p=0.01)$. Furthermore, a significant correlation was observed between serum IgE levels and the effect of BDP on IHCA, measured with forced oscillation technique. In this study, beclomethasone dipropionate, $1000 \mu \mathrm{g}$.day ${ }^{-1}$ for 6 weeks, decreased indirect bronchial hyperresponsiveness as assessed by cold air bronchoprovocation in asthmatic patients. The forced oscillation technique proved a more sensitive method to detect changes in bronchial tone than flow-volume recordings.

\section{INTRODUCTION}

Asthma is characterized by an increased responsiveness of the tracheobronchial tree to a variety of specific and nonspecific stimuli. The degree of bronchial hyperresponsiveness (BHR), as assessed by methacholine and histamine challenge, is closely related to the severity of asthma [1]. BHR is considered to occur as a result of inflammation in the asthmatic airways [2]. Even in very mild asthmatic patients an inflammatory process is present in the airways $[3,4]$. Inhaled corticosteroids improve asthma symptoms, decrease airway inflammation [5] and reduce the level of BHR [6-9]. However despite distinct improvement of asthma symptoms by inhaled corticosteroids, only moderate changes in BHR, as assessed with histamine and methacholine, are observed. Moreover, histamine thresholds in patients with 
asthma show considerable overlap with the general population [10]. Therefore, besides direct bronchial challenge tests, techniques have been developed which influence bronchial smooth muscle indirectly in order to better represent natural circumstances. Isocapnic hyperventilation with cold air (IHCA) represents a reliable and well standardized method for evaluating indirect bronchial hyperresponsiveness [11-13]. In comparison to pharmacological stimuli, bronchoprovocation with IHCA is better able to distinguish asthmatic patients from the general population [11], and from patients with COPD [14,15]. Most broncho-provocation tests evaluate the response in bronchial tone by measuring the forced expiratory volume in one second $\left(\mathrm{FEV}_{1}\right)$. However, the inspiratory manoeuvre which precedes measurement of $\mathrm{FEV}_{1}$ may change bronchial tone and, therefore, influences the result of bronchoprovocation testing, both in normal and asthmatic subjects $[7,16]$. Impedance measurement of the respiratory system by forced oscillation represents a technique which enables evaluation of bronchial hyperresponsiveness both with direct [17-19] and indirect stimuli [20-22]. The technique requires little co-operation from the patient and allows evaluation of the bronchial response during quiet breathing.

The aim of this study was to evaluate the effect of inhaled beclomethasone dipropionate on bronchial provocation with isocapnic hyperventilation with cold air in stable asthmatic patients. In addition to flow-volume recordings, impedance measurement by forced oscillation technique was used to evaluate bronchial response.

\section{MATERIAL AND METHODS}

\section{Subjects}

Forty patients, equally distributed over both sexes, were included in the study. Patient characteristics are presented in Table 1 . The following inclusion criteria were met by all patients: a clinical diagnosis of asthma, defined as recurrent attacks of dyspnea with perceptible wheezing; normal baseline impedance measurements as defined by a resonant frequency $\left(f_{0}\right)$ lower than $16 \mathrm{~Hz}$ and the absence of frequency dependence (defined as a negative value for $\left(\mathrm{R}_{28 \mathrm{H}_{2}}-\mathrm{R}_{8 \mathrm{H}}\right) / 20$ ) (Table 2). Patients entering the study all had evidence of bronchial hyperresponsiveness, as defined by a provocative dose of histamine causing a $20 \%$ fall in $\mathrm{FEV}_{1}\left(\mathrm{PD}_{20}\right) \leq 8$ $\mu \mathrm{mol}$. All patients had positive skin tests for at least one aero-allergen (number of positive tests (mean \pm SD) $4.4 \pm 2.4$ ). Patients were in a clinically stable condition and showed no evidence of a recent respiratory tract infection. None of the patients had been treated with inhaled or oral corticosteroids within 3 months prior to entry into the study. Only $\beta_{2}$-sympaticomimetic drugs were allowed for control 
Table 1. Subject characteristics. Anthropometric and spirometric data.

\begin{tabular}{lll}
\hline & $\begin{array}{l}\text { BDP } \\
\text { mean } \pm \text { S.D. }\end{array}$ & $\begin{array}{l}\text { placebo } \\
\text { mean } \pm \text { S.D. }\end{array}$ \\
\hline M/F & $10 / 10$ & $10 / 10$ \\
Age $(\mathrm{y})$ & $29 \pm 7$ & $28 \pm 6$ \\
Height $(\mathrm{cm})$ & $172 \pm 7$ & $172 \pm 12$ \\
Weight $(\mathrm{kg})$ & $75 \pm 12$ & $74 \pm 14$ \\
FEV $(\%$ pred) & $101 \pm 12^{\star}$ & $92 \pm 12$ \\
IVC $(\%$ pred) & $107 \pm 13$ & $103 \pm 11$ \\
PD $_{20}$ histamine & $1.3 \pm 1.3$ & $1.1 \pm 1.9$ \\
$(\mu$ mol) & & \\
\hline
\end{tabular}

$\mathrm{FEV}_{1}$ : forced expiratory volume in one second; IVC: inspiratory vital capacity; $\mathrm{PD}_{20}$ histamine: provocative dose of histamine producing a $20 \%$ fall in $\mathrm{FEV}$; $\mathrm{M}$ : male; $\mathrm{F}$ : female. ${ }^{\star} \mathrm{p}=0.02$ between groups.

Table 2. Changes in Forced Oscillation Parameters after cold air bronchoprovocation at entry (mean \pm S.D.)

\begin{tabular}{|c|c|c|c|c|}
\hline & \multicolumn{2}{|l|}{ BDP } & \multicolumn{2}{|l|}{ Placebo } \\
\hline & Before & After IHCA & Before & After IHCA \\
\hline R8 (kPa.s/L) & $0.314 \pm 0.082$ & $0.650 \pm 0.200^{*}$ & $0.363 \pm 0.074$ & $0.679 \pm 0.201^{*}$ \\
\hline R28 (kPa.s/L) & $0.352 \pm 0.085$ & $0.418 \pm 0.070^{*}$ & $0.377 \pm 0.081$ & $0.430 \pm 0.102^{*}$ \\
\hline F.D. (kPa.s/L) & $0.002 \pm 0.002$ & $-0.012 \pm 0.008^{\star}$ & $0.001 \pm 0.003$ & $-0.012 \pm 0.007^{*}$ \\
\hline X8 (kPa.s/L) & $-0.012 \pm 0.024$ & $-0.274 \pm 0.248^{*}$ & $-0.014 \pm 0.038$ & $-0.273 \pm 0.241^{*}$ \\
\hline$f_{0}(\mathrm{~Hz})$ & $9.1 \pm 1.7$ & $28.6 \pm 10.1^{\star}$ & $10.3 \pm 3.4$ & $29.3 \pm 7.9^{*}$ \\
\hline
\end{tabular}

R8: Resistance at $8 \mathrm{~Hz}$; R28: Resistance at $28 \mathrm{~Hz}$; F.D.: frequency dependence of resistance ((R28-R8)/20); X8: Reactance at $8 \mathrm{~Hz} ; f_{0}$ : resonant frequency. ${ }^{*} \mathrm{p}<0.01$ before and after IHCA within groups. At entry, no statistically significant differences were observed between groups.

of asthma. Patients were asked to refrain from using $\beta_{2}$-sympaticomimetic drugs at least 8 hours before bronchoprovocation testing. The protocol was approved by the Ethics Committee of the University Hospital Maastricht and written informed consent was obtained from all patients.

\section{Study design}

The study was a double-blind placebo-controlled parallel-group study, in which subjects were randomly allocated to receive either beclomethasone dipropionate (BDP) $250 \mu \mathrm{g} /$ puff 2 puffs b.i.d. by metered dose inhaler or placebo for six weeks. 
In order to avoid possible sex-related differences in airway diameter, additional stratification was performed according to gender. The time schedule consisted of a run-in period of one week, followed by a treatment period of 6 weeks, with follow-up visits scheduled every 2 weeks. At every visit, diary-information and peak flow-registrations were assessed and cold air bronchoprovocation was performed.

\section{Asthma-assessment}

During the study period, assessment of asthma severity was made in three ways: 1:) all patients were given a diary, in which they recorded asthma symptom scores $(0=$ no complaints to $5=$ major interference with daily activities, inability to work); 2 :) the use of $\beta_{2}$-sympaticomimetic drugs was recorded (patients were instructed to use these only if needed) and 3:) patients recorded peak expiratory flow rates (3 successive measurements) in the morning and evening using a mini-Wright peakflow meter (Airmed, Clement Clarke International Ltd., London, England).

\section{Cold air challenge}

Cold air challenges (IHCA) were performed using a heat-exchange system (Jaeger $\mathrm{GmbH}$, Würzburg, FRG), as described previously [21,22]. The patients inhaled dry air delivered from a cylinder. Temperature of the air leaving the cooling system was $-20^{\circ} \mathrm{C}$. The flow of air could be adjusted by a needle valve and was measured by a rotameter. Patients were instructed to breathe at a predetermined ventilation rate of $60 \%$ of the predicted indirect maximal breathing capacity (defined as $35 \mathrm{xFEV}_{1}$ ) by maintaining the size of a guide balloon. To avoid hypocapnia, $\mathrm{CO}_{2}$ was added to the system at a rate of $5 \%$ of the predetermined minute ventilation [12]. Hyperventilation was sustained for 3 minutes, after quiet breathing into the system for one minute. Prior to cold air bronchoprovocation, three successive measurements of the respiratory impedance by forced oscillations were performed, followed by flow-volume measurements using a pneumotachograph (Masterlab, Jaeger GmbH, Würzburg, FRG). Three minutes after cold air bronchoprovocation, measurements were repeated in the same order.

\section{Forced oscillation technique}

The technique used in our study is similar to the method developed by Làndsér et $a l[24]$ and has been published previously $[18,21,22]$. In short, a complex pseudorandom noise oscillation signal, containing various harmonics in steps of $4 \mathrm{~Hz}$ ranging from $4-52 \mathrm{~Hz}$, was applied at the mouth during spontaneous quiet breathing. Cheeks and mouth floor were supported by the hands of the patient. 
Mouth pressure and flow rate were recorded by transducers (MP $45^{\circledR}$, Validyne, Northridge, CA, USA), and the recorded signals were fed directly into a Fourier analysing system, calculating impedance values for each frequency applied. The impedance value can be divided into a resistance $(\mathrm{R})$ and a reactance $(\mathrm{X})$. The total resistance of the respiratory system $\left(R_{n}\right)$ is the sum of resistance of central airways, peripheral airways, lung parenchyma and chest wall. In normal individuals, the resistance increases with increasing frequency of the signal applied $[18,20]$. The slope of the curve is defined by $\left(\mathrm{R}_{28 \mathrm{H}_{2}}-\mathrm{R}_{8 \mathrm{H}}\right) / 20$ and is called the frequency dependence of resistance (FD) $[18,21,22]$.

The reactance value depends on the elastic and the inertial properties of the system. The frequency at which the sum of elastic and inertial properties equals zero is called the resonant frequency $\left(f_{0}\right)$. For this study, resistance was measured at 8 $\mathrm{Hz}$ (R8), at $28 \mathrm{~Hz}$ (R28) and frequency dependence of resistance (FD). The reactance of the impedance was characterized by reactance at $8 \mathrm{~Hz}(\mathrm{X} 8)$ and the resonant frequency $\left(f_{0}\right)$. Only impedance values with a coherence function (comparable with a signal-to-noise-ratio) equal to or greater than 0.95 were used for analysis.

\section{Data analysis}

All data described are mean $\pm S D$, unless otherwise specified. Differences between groups were compared with Mann-Whitney U-test. In order to evaluate differences between the two treatment regimens, repeated measures analysis of variance (ANOVA) (BMDP Statistical Software Inc., Los Angeles, USA) was performed; this statistical method allows comparison of individual responses and compensates for baseline response differences. The model used in our study assumes a fixed effect of treatment in time. Differences were considered significant at a p-level less than 0.05 (two-sided).

\section{RESULTS}

Thirty-five of 40 patients completed the study. In the placebo-group, 3 patients withdrew, one patient at 2 weeks and 2 patients at 4 weeks, because of lack of cooperation. In the beclomethasone dipropionate-group, 2 patients were excluded from the study at 6 weeks of treatment; one patient due to inability to attend the follow-up visit in time. The other patient had to be treated with oral corticosteroids for generalized eczema, which she had also experienced before the study. All data up to withdrawal have been included in the analysis.

Patient characteristics of both groups are presented in Table 1. At entry, the $\mathrm{BDP}$-treated group showed a higher baseline $\mathrm{FEV}$, than the placebo-group (101\% 

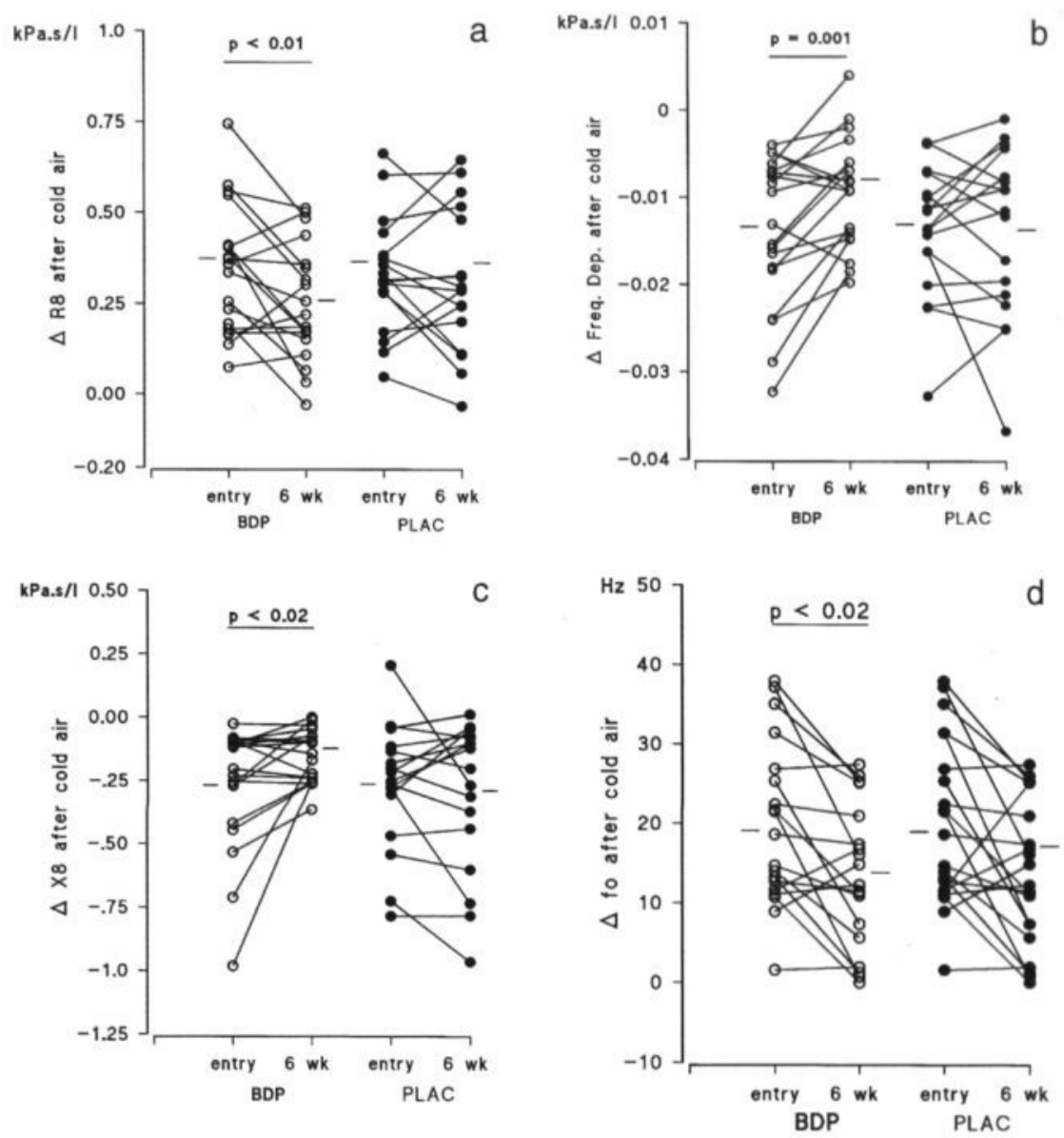

Figure 1a-d. Changes in R8 (fig. 1a), frequency dependence (fig. 1b), X8 (fig. 1c) and $f_{0}$ (fig. 1d) after IHCA for individual patients, both at entry and after 6 weeks follow-up. For legends: see table 2 . Treatment with beclomethasone dipropionate during 6 weeks resulted in statistically significant changes for all parameters shown.

predicted versus $92 \%, \mathrm{p}<0.02$ ). Baseline values for forced oscillation parameters (Table 2 ) were not statistically different between groups, although a slightly lower value for R8 was observed in the BDP-group than in the placebo-group (0.314 versus $0.363 \mathrm{kPa} . \mathrm{s}^{\mathrm{L}} \mathrm{L}^{-1}$, n.s.). Isocapnic hyperventilation with cold air resulted in similar changes in both groups. FEV decreased $($ mean $\pm \mathrm{SD}) 18 \pm 15 \%$ predicted from baseline in the BDP-group and $19 \pm 14 \%$ in the placebo-group. Impedance measurements after cold air bronchoprovocation yielded a similar change in 

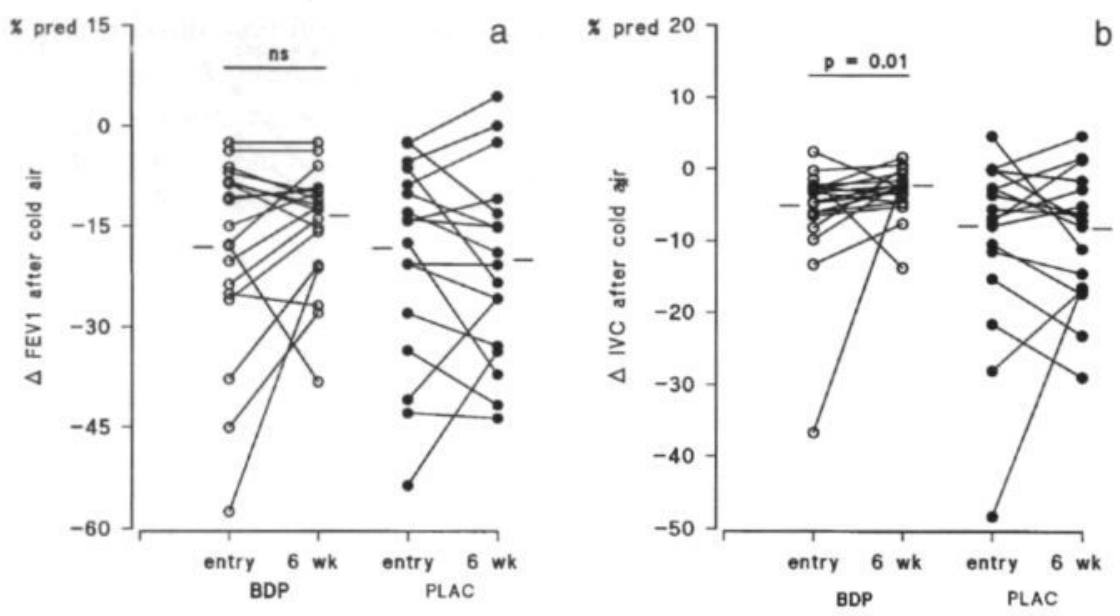

Figure 2a-b. Changes in FEV, (fig. 2a) and IVC (fig. 2b) after IHCA for individual patients. Figures show data obtained at entry and after 6 weeks follow-up. Treatment with beclomethasone dipropionate resulted in a small change in fall of IVC after IHCA. No statistical significant effect was observed for FEV,

forced oscillation pattern in both groups: a large increase in R8, a small increase in R28, the occurrence of a negative slope of the resistance-frequency curve, a more negative value of X8 and an increase in resonant frequency $(f o)$ (Table 2). At entry, no statistically significant differences in flow-volume and forced oscillation changes were observed between groups after IHCA.

Baseline impedance and flow-volume measurements did not change significantly in either treatment groups during 6 weeks of treatment. After 6 weeks of beclomethasone dipropionate treatment, statistically significant changes were observed in forced oscillation response to IHCA (Fig. 1a-d). Treatment with beclomethasone dipropionate resulted in: a diminished increase of R8 after IHCA (at entry (mean \pm SD): $0.336 \pm 0.174$; after 6 weeks: $0.250 \pm 0.160$ kPa.s.L $L^{-1}(p=0.006$; $-26 \%$ baseline)); a decrease in steepness of the slope (FD) of the resistance-curve after IHCA (at entry: $-0.013 \pm 0.009$, at 6 weeks $-0.009 \pm 0.006$ kPa.s. $\mathrm{L}^{-1}(\mathrm{p}=0.001 ;-31 \%$ baseline)); a decrease in X8 changes after IHCA (at entry: $-0.263 \pm 0.246$, after 6 weeks $-0.155 \pm 0.105$ kPa.s. $L^{-1}(p=0.012 ;-41 \%$ baseline)) and a decrease in change of $f_{0}$ after IHCA (at entry: $19.5 \pm 10.1$, after 6 weeks $13.3 \pm 9 \mathrm{~Hz}$ ( $\mathrm{p}=0.015 ;-32 \%$ baseline).

In contrast, flow-volume measurements only yielded a statistically significant change in IVC after IHCA (at entry: $-6.1 \pm 8.0 \%$ pred., after 6 weeks $-3.1 \pm 3.4 \%$ $(\mathrm{p}=0.01)$ ). No significant changes were observed in other parameters (Fig. 2). 


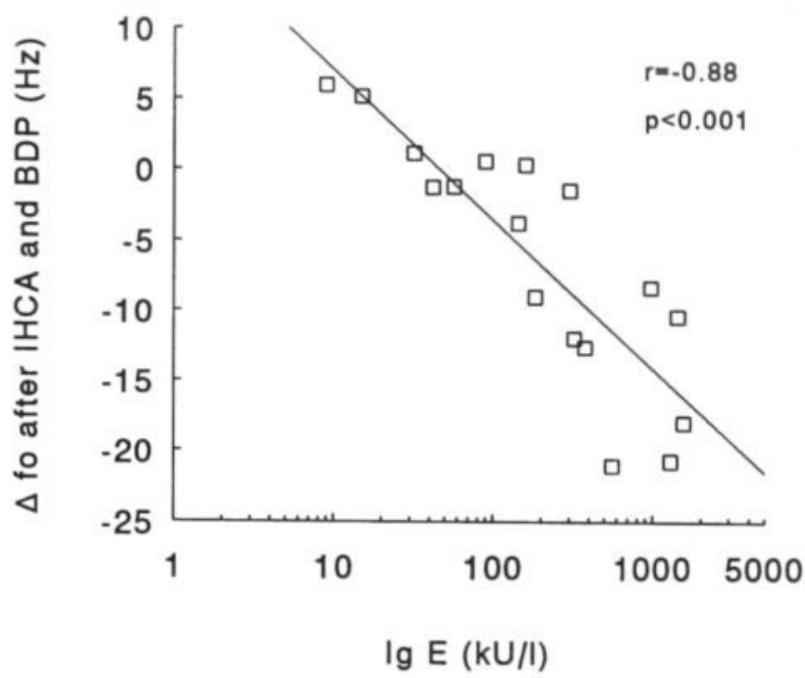

Figure 3. A significant correlation was observed for lgE-levels at entry and changes in forced oscillation parameters after IHCA after 6 weeks beclomethasone dipropionate. The $\mathrm{Y}$-axis indicates the IHCA-induced change in $f_{0}$ after 6 weeks BDP in comparison to baseline-response. The figure shows a significant correlation between IgE-levels and beclomethasone-induced change in $f_{0}(r=-0.88, p<0.001$, Spearman rank correlation $)$. Note that $\lg \mathrm{E}$ levels are shown on a logarithmic scale.

Levels of total serum $\operatorname{IgE}$ in patients were found to be significantly correlated with the level of response to BDP as measured by forced oscillation technique (Spearman rank correlation for changes in R8 after 6 weeks BDP in comparison to entry $(r=-0.80, p<0.001)$; for changes in frequency dependence $(r=0.81, p<0.001)$; for changes in X8 $(\mathrm{r}=-0.68, \mathrm{p}<0.01)$; and for changes in $f_{0}(\mathrm{r}=-0.88, \mathrm{p}<0.001)$ (Fig 3)). No significant correlations were found for total numbers of eosinophils and histamine $\mathrm{PD}_{20}$-levels and response to inhaled steroids in our patient group. No clinically significant differences were observed in asthma symptom-score, peak flow registration and peak flow variability between groups both at entry and after six weeks.

Adverse effects were reported by 6 patients in the BDP-treated group: complaints of a sore throat ( 2 patients); hoarseness ( 2 patients); dry cough (1 patient) and one patient was suspected of oral candidiasis. However no smear was made to evaluate the presence of oral candidiasis. In the placebo group a dry irritant cough was reported by 1 patient and 2 patients complained of a sore throat. 


\section{DISCUSSION}

In this study, inhaled beclomethasone dipropionate (BDP) reduced bronchial hyperresponsiveness in stable mild asthmatic patients, as assessed by isocapnic hyperventilation with cold air. The forced oscillation technique was more sensitive in detecting BDP-induced changes in bronchial tone after IHCA in comparison to conventional flow-volume recordings. Furthermore a high correlation was observed between serum IgE levels and the effect of BDP on IHCA, as measured by forced oscillation technique.

At the present time, inhaled corticosteroids play an important role in the treatment of asthma. Inhaled corticosteroids reduce BHR to pharmacological stimuli in a dose- and time-dependent way [7-9,24]. This report is the first to discuss the influence of inhaled BDP on the bronchial challenge with IHCA in asthmatic patients assessed both with forced oscillation technique and conventional pulmonary function testing. Impedance measurement of the respiratory system was chosen to overcome modulation in bronchial tone, which may result from a preceding deep inspiratory manoeuvre $[7,16]$. In the present study, a characteristic pattern of changes after IHCA was observed in forced oscillation parameters; an increase of resistance at lower frequencies, the development of a negative slope of resistance and an increase in resonant frequency. This pattern of changes is characteristic for asthmatic patients and these results concur with previous studies [20-22].

The present study showed that BDP $1000 \mu$ g.day ${ }^{-1}$ for 6 weeks, significantly attenuated the response to IHCA assessed with the technique of forced oscillations, whereas only small changes in $\mathrm{FEV}_{\text {, }}$ response to IHCA were observed. From the literature, one would expect an effect of BDP on change in FEV, after IHCA, but considering the large variability in $\mathrm{FEV}_{\text {, }}$ changes after IHCA detected in the patient population, it is likely that the number of patients in the present study was not high enough to detect differences in $\mathrm{FEV}_{1}$. No changes were detected in asthma-symptom scores or PEF-scores in our BDP-treated group, but this is not surprising considering the fact that all of the patients had mild asthma. Furthermore, it appeared that the patients treated with BDP were the patients with the better values of $\mathrm{FEV}_{1}$.

So far, no other studies have been published using forced oscillation technique in response measurement of corticosteroids in IHCA. Several reports have been published regarding the influence of long term treatment with inhaled corticosteroids on exercise induced asthma [25-27] and on eucapnic hyperventilation with room air $[28,29]$. Only one study has evaluated the effect of an inhaled corticosteroid on IHCA [30]. In this study, budenoside $800 \mu$ g.day ${ }^{-1}$ for four weeks, induced a small but significant change in $\mathrm{FEV}_{1}(-8.5 \%)$ after IHCA in asthmatic patients. Other studies $[27,29]$ have observed larger effects of inhaled corticosteroids in 
exercise-induced asthma, however in these studies baseline $\mathrm{FEV}_{1}$ was clearly lower and BHR more severe than in the present patient group. Apart from the fact that the response to exercise in asthmatics is correlated with the severity of BHR as assessed by methacholine or histamine [31], the effect of pharmacological intervention also depends upon the basic level of bronchial reactivity.

In the present study, the forced oscillation technique in our study detected changes in airway bronchial tone that were not detected by conventional flowvolume recordings. The superiority of forced oscillation technique in detecting differences in bronchial tone in comparison to conventional flow-volume recordings was noted before. Wesseling et al. [21] noted differences in forced oscillation recordings in IHCA at $40 \%$ maximum breathing capacity whereas no difference was observed in $\mathrm{FEV}_{1}$. Van Noord et al.[19] described the reciprocal value of the resistance at $6 \mathrm{~Hz}$ as a more sensitive parameter for detection of histamine induced bronchoconstriction in asthmatics than $\mathrm{FEV}_{1}$ measurement in response evaluation. Only measurement of specific airway conductance ( $\mathrm{sGaw}$ ) proved more sensitive in patients with more or less normal lung function.

Furthermore, the present study also observed that the effect of BDP on IHCA, as assessed by forced oscillation technique, significantly correlated with total serum IgE. Patients with high levels of $\operatorname{IgE}$ showed a greater response to treatment with BDP than patients with lower levels. These findings concur with a previous study, wherein response to inhaled corticosteroids in asthmatic patients, measured by changes in histamine $\mathrm{PC}_{20}$, also correlated with total serum IgE levels [32].

Up till now several mechanisms have been proposed to explain airway obstruction induced by exercise, i.e. hyperventilation with cold air [33]. Inhaled corticosteroids could influence response to cold air challenge by reducing plasma exudation in asthmatic airways [34] or by modulating secondary mediator release by inflammatory cells. Bronchial biopsy studies have shown that even in mild asthmatic patients inflammatory cells are present in the airways [5]. BDP was shown to reduce the number of eosinophils and mast cells in bronchial mucosa of asthmatic patients after 6 weeks of treatment [35]. In the present study, however, no bronchial biopsies were performed and, therefore, no answer can be provided regarding the mechanism by which BDP influences BHR in this study.

In conclusion, this study has demonstrated that treatment with beclomethasone dipropionate, $1000 \mu \mathrm{g}$.day ${ }^{-1}$ for 6 weeks, modulated bronchial response to isocapnic hyperventilation with cold air in patients with mild stable asthma. We have also shown that the technique of forced oscillation was more sensitive to changes in bronchial tone than conventional flow-volume recordings, and represents a sen- 
sitive technique to assess pharmacological modulation of indirect bronchial hyperresponsiveness.

\section{REFERENCES}

1. Hargreave FE, Ryan G, Thomson NC, O'Byrne PM, Latimer K, Juniper EF. Bronchial hyperresponsiveness to histamine or methacholine in asthma: measurement and clinical significance. J Allergy Clin Immunol 1981; 68: 347-355.

2. Barnes PJ. New concepts in the pathogenesis of bronchial hyperresponsiveness and asthma. J Allergy Clin Immunol 1989; 83: 1013-1026.

3. Laitinen LA, Heino M, Laitinen A, Kava T, Haahtela T. Damage of the airway epithelium and bronchial reactivity in patients with asthma. Am Rev Respir Dis 1985; 131: 599-606.

4. Beasley R, Roche WR, Roberts JA, Holgate ST. Cellular events in the bronchi in mild asthma and after bronchial provocation. Am Rev Respir Dis 1989; 139: 806-817.

5. Laitinen LA, Laitinen A, Haahtela T. A comparative study of the effects of an inhaled corticosteroid, budesonide, and a beta-2-agonist, terbutaline, on airway inflammation in newly diagnosed asthma: A rondomized, double-blind, parallel-group controlled trial. J Allergy Clin Immunol 1992; 90: 32-42.

6. Juniper EF, Frith PA, Hargreave FE. Long term stability of bronchial responsiveness to histamine. Thorax 1982; 37: 288-291.

7. Bel EH, Timmers MC, Hermans J, Dijkman J, Sterk PJ. The long-term effects of nedocromil sodium and beclomethasone dipropionate on bronchial hyperresponsiveness to methacholine in nonatopic asthmatic subjects. Am Rev Respir Dis 1990; 141:21-28.

8. Juniper EF, Kline PA, Vanzieleghem MA, Ramsdale EH, O'Byrne PM, Hargreave FE. Effect of long term treatment with an inhaled corticosteroid (Budesonide) on airway hyperresponsiveness and clinical asthma in non-steroid-dependent asthmatics. Am Rev Respir Dis 1990; 142: 832-836.

9. Kraan J, Koëter GH, Van der Mark ThW, Boorsma M, Kukler J, Sluiter HJ, De Vries K. Dosage and time effects of inhaled budenoside on bronchial hyperreactivity. Am Rev Respir Dis 1988; 137: 44-48.

10. Cockcroft DW, Berscheid BA, Murdock KY. Unimodal distribution of bronchial responsiveness to inhaled histamine in a random human population. Chest 1983; $5: 751-754$.

11. Deal EC, McFadden ER, Ingram RH, Breslin FJ, Jaeger JJ. Airway responsiveness to cold air and hyperpnea in normal subjects and in those with hay fever and asthma. Am Rev Respir Dis 1980; 121: 621-628.

12. Assoufi BK, Dally MB, Newman-Taylor AJ, Denison DM. Cold air test: a simplified standard method for airway reactivity. Bull Eur Physiopathol Respir 1986; 22: 349-357.

13. Tessier P, Cartier A, L'Archevêque J, Ghezzo H, Martin RR, Malo JL. Within- and between-day reproducibility of isocapnic cold air challenges in subjects with asthma. J Allergy Clin Immunol 1986; 78: 379-387.

14. O'Byrne PM, Ramsdale EH, Hargreave F. Isocapnic hyperventilation for measuring airway hyperresponsiveness in asthma and in chronic obstructive pulmonary disease. Am Rev Respir Dis 1991; 143: 1444-1445.

15. Mönkhof $M$, Wönne R, Hofman D. Kaltluftprovokation als methode zur differentialdiagnose von astma bronchiale und chronischer bronchitis. Pneumologie 1991; 45: 899-902.

16. Orehek J, Nicoli MM. Delpierre S, Beaupre A. Influence of the previous deep inspiration on the spirometric measurement of provoked bronchoconstriction in asthma. Am Rev Respir Dis 1981; 123: 269-272. 
17. Kabiraj MU, Rolf C, Simonsson BG. Drug-induced changes in airways obstruction reflected by forced expiratory flows and airway resistance measured with an oscillometric method using quiet breathing. Respiration 1981; 41: 90-95.

18. Wouters EFM, Polko AH, Schouten HJA, Visser BF. Contribution of impedance measurement of the respiratory system to bronchial challenge tests. J Asthma 1988; 25(5): 259-267.

19. Van Noord JA, Clement J, Van de Woestijne KP, Demedts M. Total respiratory resistance and reactance as a measurement of response to bronchial challenge with histamine. Am Rev Respir Dis 1989; 139: 921-926.

20. Decramer M, Demedts M, Van de Woestijne KP. Isocapnic hyperventilation with cold air in healthy non-smokers, smokers and asthmatic subjects. Bull Eur Physiopathol Respir 1984; 20: 237-243.

21. Wesseling GJ, Wouters EFM. Respiratory impedance measurements in a dose-response study of isocapnic hyperventilation with cold air. Respiration 1992; 59: 259-264.

22. Wesseling GJ, Vanderhoven-Augustin IMJ, Wouters EFM. Forced oscillation technique and spirometry in cold air provocation tests. Thorax 1993; 48: 254-259.

23. Làndsér FJ, Nagels J, Demedts M, Billiet L, Van de Woestijne KP. A new method to determine frequency characteristics of the respiratory system. J Appl Physiol 1976; 41: 101-106.

24. Vathenen AS, Knox AJ, Wisniewski A, Tattersfield AE. Time course of change in bronchial reactivity with an inhaled corticosteroid in asthma. Am Rev Respir Dis 1991; 143: 1317-1321.

25. Waalkens HJ, Van Essen-Zandvliet EEM, Gerritsen J, Duiverman EJ, Kerrebijn KF, Knol K. The effect of an inhaled corticosteroid (budenoside) on exercise-induced asthma in children. Eur Respir J 1993; 6: 652-656.

26. Henriksen OM, Dahl R. Effects of inhaled budenoside alone and in combination with low-dose terbutaline in children with exercise-induced asthma. Am Rev Respir Dis 1983; 128 : 993-997.

27. Molema J, Van Herwaarden CLA, Folgering HThM. Effects of long-term treatment with inhaled cromoglycate and budenoside on bronchial hyperresponsiveness in patients with allergic asthma. Eur Respir J 1989; 2: 308-316.

28. Wiebicke W, Jörres R, Magnussen H. Comparison of the effects of inhaled corticosteroids on the airway response to histamine, methacholine, hyperventilation and sulfur dioxide in subjects with asthma. J Allergy Clin Immunol 1990; 86: 915-923.

29. Vathenen AS, Knox AJ, Wisniewski A, Tattersfield AE. Effect of inhaled budesonide on bronchial reactivity to histamine, exercise and eucapnic dry air hyperventilation in patients with asthma. Thorax 1991; 46: 811-816.

30. Claussen M, Sill V. Beeinflussung der unspezifischen bronchialen Hyperreagibilitat auf Kaltlufthyperventilation und Carbachol durch nedrocomil und budesonid. Pneumologie 1993; 47: 209-214.

31. Chatman M, Bleecker ER, Smith PL, Rosenthal RR, Mason P, Norman PS. A comparison of histamine, methacholine and exercise airway reactivity in normal and asthmatic subjects. Am Rev Respir Dis 1982; 126: 235-240.

32. Kerstjens HAM, Schouten JP, Brand PLP, Schoonbrood DFME, Sterk PJ, Postma DS and the dutch CNSLD Study Group. Importance of total serum IgE for improvement in airways hyperresponsiveness with inhaled corticosteroids in asthma and chronic obstructive pulmonary disease. Am J Respir Crit Care Med 1995; 151: 360-368.

33. McFadden ER, Gilbert IA. Exercise-induced asthma. N Eng/ J Med 1994; 330: 1362-1367.

34. Van de Graaf AA, Out TA, Roos CM, Jansen HM. Respiratory membrane permeability and bronchial hyperreactivity in patients with stable asthma: effect of therapy with inhaled steroids. Am Rev Respir Dis 1991; 143:362-366.

35. Djukanovic R, Wilson JW, Britten KM, Wilson SJ, Walls AF, Roche WR, Howarth PH, Holgate ST. Effect of an inhaled corticosteroid on airway inflammation in asthma. Am Rev Respir Dis 1992; 145: 669-674. 


\section{Beclomethasone dipropionate attenuates} levels of soluble TNF-Receptor 55 and circulating ICAM-1 in patients with stable asthma

H.J. Pennings, M.A. Dentener, W.A. Buurman", E.F.M. Wouters.

From the Department of Pulmonology, University Hospital Maastricht and the Department of Surgery", Maastricht University, The Netherlands. 


\section{SUMMARY}

Asthma is an inflammatory disease, characterized by the accumulation of inflammatory cells in the bronchial mucosa. Upregulation of adhesion molecules, both on vascular and epithelial cells, plays an important role in initiating the influx of inflammatory cells in bronchial mucosa. In acute asthma, elevated levels of these inflammatory mediators have been detected in the general circulation.

Aim of the present study was to compare levels of inflammatory mediators (soluble E-selectin, soluble Intercellular adhesion molecule-1 (sICAM-1) and TNFreceptor-55 and -75 (sTNF-R55/sTNF-R75)) in the general circulation both in stable mild asthmatic patients and healthy controls and to analyse the influence of 6 weeks treatment with inhaled beclomethasone dipropionate (BDP) on levels of these inflammatory mediators. Study design consisted of a double-blind, placebo-controlled, parallel-group study, in which effects of 6 weeks treatment with BDP $500 \mu \mathrm{g}$ b.i.d. were compared to placebo in patients with stable mild asthma. Effects of treatment on levels of inflammatory mediators, pulmonary function and asthma-symptom scores were evaluated. Results show that at baseline no differences were observed in levels of inflammatory mediators between patients with stable asthma and healthy controls. Treatment with BDP significantly decreased levels of sTNF-R55 after 2 to 6 weeks $(\mathrm{p}<0.02)$ and sICAM-1 after 6 weeks $(\mathrm{p}<0.05)$. Decreases of $s$ TNF-R55 and sICAM-1 were significantly correlated to levels at baseline $(\mathrm{r}=-0.56, \mathrm{p}<0.02$ respectively $\mathrm{r}=-0.53, \mathrm{p}<0.03)$. BDP also induced a significant decrease in number of blood eosinophils $(\mathrm{p}<0.02)$. In contrast, no changes in sTNF-R75 and sE-Selectin were observed. The results of the present study suggest that BDP-induced changes in levels of circulating inflammatory mediators may reflect attenuation of bronchial inflammation.

\section{INTRODUCTION}

Asthma is an inflammatory disease, characterized by an increase of inflammatory cells in bronchial mucosa [1]. The steroid beclomethasone dipropionate (BDP) is widely used for treatment of asthma, since it has been demonstrated to achieve both functional and structural improvement in asthma. BDP has been shown to induce a decrease in bronchial hyperresponsiveness (BHR) [2,3], which is parallelled by a decrease in inflammatory cell numbers in bronchial mucosa [2]. Corticosteroids have been shown to decrease adhesion molecule expression on stimulated endothelial and epithelial cells in vitro and this may explain clinical activity of corticosteroids in disease [4,5]. Evidence for the involvement of adhesion molecules in the pathophysiology of asthma has been shown in several studies: endothelial leucocyte adhesion molecule-1 (E-selectin) expression was enhanced on en- 
dothelial cells and an increased expression of intercellular adhesion molecule-1 (ICAM-1) was observed on cells, present in asthmatic airways [6,7]. Also in sputum of asthmatic patients enhanced levels of soluble ICAM-1 (sICAM-1) and an increased ICAM-1 expression on T-lymphocytes have been demonstrated [8]. In line with these data, allergen exposure by segmental allergen challenge was shown to increase levels of sICAM-1 in epithelial lining fluid [9]. The expression of ICAM-1 is regulated by cytokines such as tumor necrosis factor $\alpha$ (TNF $\alpha$ ) $[10,11]$. TNF $\alpha$ has been shown in several studies to be involved in the pathophysiology of asthma $[12,13]$. TNF $\alpha$ levels are enhanced in BAL [14] and in induced sputum [15] following antigen challenge. These data correlate well with data of enhanced sICAM-1 in BAL after allergen challenge. Interestingly, increased levels of sICAM-1 were also detectable in the general circulation [9]. Next to cytokine levels, also soluble TNF-receptor levels in the general circulation are known to reflect inflammatory disease [16]. Enhanced levels of soluble TNFreceptors have been detected in patients with chronic inflammatory disease $[17,18,19]$ and in neoplastic disease [20]. In asthma, elevated levels of sICAM-1 and sTNF-receptors have been described in acute exacerbations $[21,22,23]$ and are considered to reflect the enhanced bronchial inflammation.

Since inhaled corticosteroids modulate the local inflammatory reaction within the airways, aim of the present study was to evaluate the effect of inhaled beclomethasone dipropionate on levels of circulating inflammatory mediators in patients with stable asthma and to correlate this with clinical parameters.

This study demonstrates that inhaled beclomethasone dipropionate $500 \mu \mathrm{g}$ b.i.d. reduces levels of sTNF-R55 and sICAM-1 in stable asthmatic patients. We speculate that the modulation of sTNF-R55 and sICAM-1 reflects attenuation of bronchial inflammation in stable asthmatic patients.

\section{MATERIAL AND METHODS}

\section{Study design}

This study was performed simultaneously with investigations of the effects of beclomethasone dipropionate on isocapnic hyperventilation with cold air, the results of which are reported elsewhere [3]. 40 Patients with mild stable asthma, equally distributed over both sexes, were included in the study. Study design consisted of a double-blind, placebo-controlled, parallel-group study, in which patients were randomly allocated to receive either beclomethasone dipropionate $250 \mu \mathrm{g} / \mathrm{puff} 2$ puffs b.i.d. by metered dose inhaler or placebo for six weeks. Time schedule consisted of a run-in period of 1 week followed by a treatment period of 6 weeks, during which control visits were scheduled every 2 weeks. All patients entering the 
study had a documented bronchial hyperresponsiveness (defined by a $\mathrm{PD}_{20}$ to histamine lower than $8 \mu \mathrm{mol}$ ) and were all atopic, with a mean number of positive skin tests for aero-allergens $4.4 \pm 2.4$ (mean $\pm \mathrm{SD}$ ).

Patients were all in a clinically stable condition and showed no evidence of recent respiratory tract infection. None of the patients had been treated with inhaled or oral corticosteroids within 3 months prior to the study. Only $\beta_{2}$-sympaticomimetic drugs were allowed for control of asthma.

During the study patients were evaluated in three ways: recording of asthmasymptoms, analysis of venous blood for hematology and acute-phase-response and determination of levels of circulating inflammatory mediators in plasma. Additionally, levels of circulating inflammatory mediators were also determined in a group of 32 healthy, nonatopic, nonasthmatic volunteers, ranging in age from $20-40$ years.

The study was approved by the local medical ethical committee and written informed consent was obtained from all patients.

Asthma-severity evaluation

Patients recorded disease-severity in three different ways using a diary: all patients recorded asthma-symptoms $(0=$ no complaints to $5=$ major interference with daily activities), the number of $\beta_{2}$-sympaticomimetic drugs used for control of asthma and peak expiratory flow rates, using mini-Wright peak-flow meters ( Airmed, Clement Clarke international Ltd., London, England).

\section{Peripheral blood analysis}

Venous blood was obtained by venapuncture. At entry, blood was routinely analysed and at every visit white blood cell count, both total numbers and differentiation, total number of eosinophils, $\mathrm{C}$-reactive protein (CRP) and pre-albumin were determined. Both CRP and pre-albumin were determined in order to evaluate the occurrence of acute-phase reactions during the study. CRP was evaluated using turbimetry; lower detection limit of the assay was $5 \mathrm{mg} / \mathrm{l}$. Pre-albumin was analysed using standard immunochemical methods, normal values ranging between $0.15-0.40 \mathrm{~g} / \mathrm{l}$.

\section{Plasma-samples}

For measurement of inflammatory mediators venous blood $(10 \mathrm{ml})$ was collected in EDTA-coated blood tubes (Sherwood Medical, Balleymoney, N-Ireland). Plasma was separated from blood cells by centrifugation at 1,000 G for 5 minutes within 1 hour after collection. Plasma samples were stored at $-70^{\circ} \mathrm{C}$ until analysis. 
All samples were evaluated in duplo and mean value of each pair of results was used for analysis. For each inflammatory mediator, samples of one patient were analysed in a single analytical set.

\section{Measurement of inflammatory mediators}

Inflammatory mediators were measured using sandwich enzyme-linked immunosorbent assay (ELISA), as described before $[11,24,25]$. In short, for detection of soluble TNF-Receptor -55 and -75 , monoclonal antibodies (mAb) MR1-1 respectively MR2-2 were used for coating. Specific biotin-labeled polyclonal rabbitanti-sTNF-R immunoglobulin-G's were used as detector reagents. After washing procedure, peroxidase labeled Streptavidine (Dako, Glostrup, Denmark) was added, followed by the addition of 3,3',5,5'-tetramethylbenzidine (TMB) substrate (Kirkegaard and Perry Laboratory, Gaitersburg, MD). Photospectrometry $(450 \mathrm{~nm})$ was used to analyse the samples. Standards used were rh-sTNF-R55 and rh-sTNF-R75. The lower detection limits of both assays was $100 \mathrm{pg} / \mathrm{ml}$. Intra-test variability was $<10 \%$. For soluble E-selectin detection, as catching mAb ENA-1 was used, followed by biotin-labeled ENA-2 as second catching antibody. In this assay $4 \mathrm{mmol} / \mathrm{L}$ calcium and $2.5 \mathrm{mmol} / \mathrm{L}$ magnesium was added to the buffers, since binding of mAb ENA-1 and ENA-2 to $s$ E-selectin is calcium-dependent. rh-E-Selectin was used as standard. Lower detection limit of the ELISA is $1 \mathrm{ng} / \mathrm{ml}$. Intratest-variability amounts $<10 \%$. Soluble ICAM-1 was analysed using $\mathrm{mAb}$ HM. 2 as catching antibody, followed by biotinylated mAb HM.1 as second antibody. rh-sICAM-1 was used as standard. Sensitivity of this ELISA was determined at $400 \mathrm{pg} / \mathrm{ml}$. Intra-assay variability ranged from $2.8-12.2 \%$ with a mean variance of $6.2 \%$.

\section{STATISTICAL ANALYSIS}

Effect of treatment on inflammatory mediators was expressed as changes from baseline in order to correct for the observed differences in baseline levels of inflammatory mediators. Since levels of inflammatory mediators were not normally distributed, for analysis non-parametric tests were performed. Differences within treatment groups were analysed using Friedman's test, whereas differences between treatment-groups were analysed using Mann-Whitney U-test for unpaired data, two sided test. A p-value $<0.05$ was considered statistically significant. The effect of BDP on levels of sICAM-1 was additionally analysed by calculating the slope of the curve (indicating mean decrease during time), as characterized by calculating linear contrast [26], and comparing the slope between the two treatment 
Table 1. Subject characteristics. Anthropometric and spirometric data (Mean \pm S.D.).

\begin{tabular}{lll}
\hline & BDP-group & Placebo \\
\hline MF & $10 / 10$ & $10 / 10$ \\
Age $(\mathrm{yr})$ & $29 \pm 7$ & $28 \pm 6$ \\
Height $(\mathrm{cm})$ & $172 \pm 7$ & $172 \pm 12$ \\
Weight $(\mathrm{kg})$ & $75 \pm 12$ & $74 \pm 14$ \\
FEV $(\%$ pred.) & $101 \pm 12^{*}$ & $92 \pm 12$ \\
IVC (\% pred.) & $107 \pm 13$ & $103 \pm 11$ \\
PD $_{20}$ histamine $(\mu \mathrm{mol})$ & $1.3 \pm 1.3$ & $1.1 \pm 1.9$ \\
eosinophils $\left(.10^{6} / \mathrm{l}\right)$ & $318 \pm 148$ & $298 \pm 229$ \\
IgE (kU/) & $430 \pm 519$ & $516 \pm 911$ \\
creatinine $(\mu \mathrm{mol} / \mathrm{l})$ & $72 \pm 9$ & $72 \pm 13$ \\
CRP $(\mathrm{U} / \mathrm{l})$ & $6 \pm 6$ & $5 \pm 1$ \\
Prealbumin $(\mathrm{g} / \mathrm{l})$ & $0.32 \pm 0.05$ & $0.30 \pm 0.04$ \\
\hline
\end{tabular}

Baseline demographic parameters did not show significant differences between the two groups of asthmatic patients, except for $\mathrm{FEV}_{1}$, which was at baseline significantly higher in the BDP-group $\left({ }^{\star} p=0.02\right)$.

groups. Correlations between different parameters were evaluated using Spearman rank correlation coefficient.

\section{RESULTS}

Thirty five patients completed the study; three patients in the placebo-group withdrew after two (one patient) and four weeks (two patients) because of lack of cooperation; in the BDP-group after six weeks of treatment one patient was excluded from the study because of treatment with oral corticosteroids for generalized eczema and one patient failed to attend the follow-up visit in time.

At baseline, asthmatic groups (placebo and BDP-treated group) were comparable in demographic variables (Table 1). Unfortunately, $\mathrm{FEV}_{1}$ in the placebo group was significantly lower than in the BDP-treated group. No differences were observed between groups in white blood cell count, number of eosinophils, CRP and prealbumin, which were all within normal range.

Levels of inflammatory mediators in asthmatic patients did not show differences when compared with levels of healthy volunteers (Table 2). These data confirm observations from previous studies. It has to be noted that all patients in the present study had stable, mild asthma.

Treatment with BDP resulted in a statistically significant, although small, decrease in sTNF-R55 (at entry (mean \pm SEM) $0.45 \pm 0.04 \mathrm{ng} / \mathrm{ml}$ versus $0.39 \pm 0.03$ $\mathrm{ng} / \mathrm{ml}$ after two weeks treatment $(\mathrm{p}<0.01$ in comparison to placebo))(Fig. 1), 
Table 2. Levels of inflammatory mediators at baseline (mean \pm SEM).

\begin{tabular}{llll}
\hline & & \multicolumn{2}{l}{ Asthma } \\
\cline { 3 - 4 } \cline { 3 - 4 } & $\begin{array}{l}\text { Controls } \\
(n=32)\end{array}$ & $\begin{array}{l}\text { BDP-group } \\
(n=20)\end{array}$ & $\begin{array}{l}\text { Placebo } \\
(n=20)\end{array}$ \\
\hline STNF-R55 $(\mathrm{ng} / \mathrm{ml})$ & $0.44 \pm 0.02$ & $0.45 \pm 0.04$ & $0.45 \pm 0.03$ \\
sTNF-R75 $(\mathrm{ng} / \mathrm{ml})$ & $1.10 \pm 0.03$ & $1.09 \pm 0.09$ & $1.08 \pm 0.06$ \\
sICAM-1 $(\mathrm{ng} / \mathrm{ml})$ & $317 \pm 17$ & $341 \pm 24$ & $327 \pm 30$ \\
SE-selectin $(\mathrm{ng} / \mathrm{ml})$ & $33 \pm 3$ & $31 \pm 3$ & $35 \pm 4$ \\
\hline
\end{tabular}

Baseline inflammatory mediators were not statistically different between healthy, age-matched controls and patients with asthma, nor were there any differences between the two different treatment-groups in asthmatic patients at baseline.

which remained statistically different between groups during the six weeks treatment period (Fig. 2). Analysis within the placebo-group did not show changes in sTNF-R55 levels. In contrast, BDP induced no changes in levels of sTNF-R75, which is intriguing since sTNF-R55 and sTNF-R75 were closely correlated in our study $(\mathrm{r}=0.61, \mathrm{p}<0.001)$ (data not shown).

We also evaluated the influence of BDP on ICAM-1 and observed that BDP induced a significant decrease in levels of sICAM-1 after 6 weeks of treatment (at entry $($ mean $\pm S E M) 341 \pm 24 \mathrm{ng} / \mathrm{ml}, 311 \pm 23 \mathrm{ng} / \mathrm{ml}$ after 6 weeks $(\mathrm{p}<0.05$ in comparison to placebo)) (Fig. 3)). Additionally, we evaluated the effect in time of BDP on sICAM-1 levels by linear contrast analysis, and observed a significant difference between the two groups (for BDP (mean \pm SEM) $-17 \pm 6 \mathrm{ng} / \mathrm{ml} / 2$ weeks versus placebo $-2 \pm 5 \mathrm{ng} / \mathrm{ml} / 2$ weeks, $\mathrm{p}<0.03$ ). Levels of $s E-S e l e c t i n-1$ did not show significant changes during treatment with BDP (data not shown).

Further analysis of the present data showed that BDP induced a statistically significant decrease in the number of circulating eosinophils $(\mathrm{p}<0.02$ in comparison with placebo), whereas no changes were observed within the placebo-treated group (Fig. 4). BDP decreased the number of eosinophils already after 2 weeks of treatment (data not shown) and the number of eosinophils remained well below baseline levels during the rest of the study-period.

As reported before, asthma-symptom-scores, pulmonary function and peak-flow measurements did not change significantly between groups during treatment with $\mathrm{BDP}$, which is not unexpected considering the normal baseline pulmonary function of the BDP-treated group.

Since clinical studies have shown correlations between levels of inflammatory mediators and disease severity, we correlated inflammatory mediators with indices of asthma severity (pulmonary function, levels of bronchial hyperresponsiveness, 


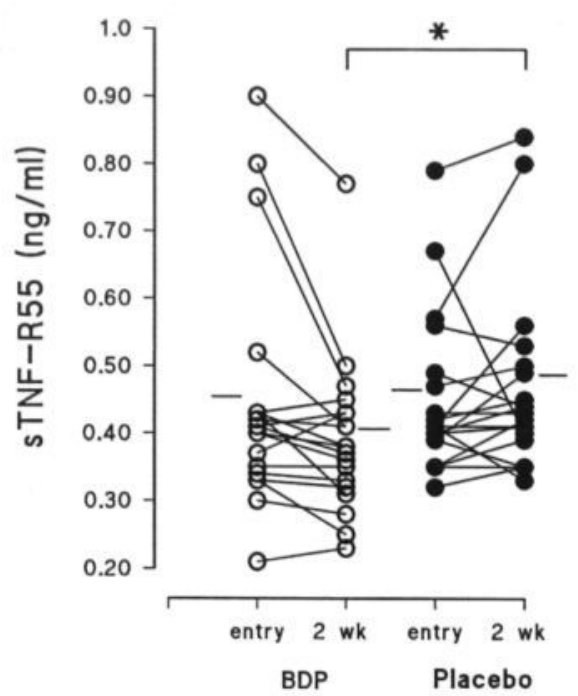

Figure 1. Beclomethasone dipropionate reduces levels of sTNF-R55 in patients with stable asthma; individual responses are shown after 2 weeks of treatment, horizontal bars represent the mean of the observed response. ${ }^{\star} p<0.01$.

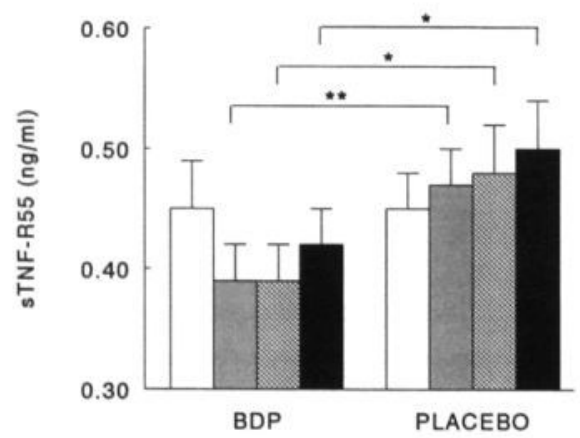

Figure 2. Time-response effect (mean \pm SEM) of treatment with beclomethasone dipropionate on sTNF-R55 in patients with stable asthma; already after 2 weeks a significant decrease from baseline is observed $\left({ }^{\star \star} p<0.01,{ }^{\star} p<0.02\right)$. Open bars: levels at entry; hatched bars: after 2 weeks; crosshatched bars: after 4 weeks; solid bars: after 6 weeks treatment. 


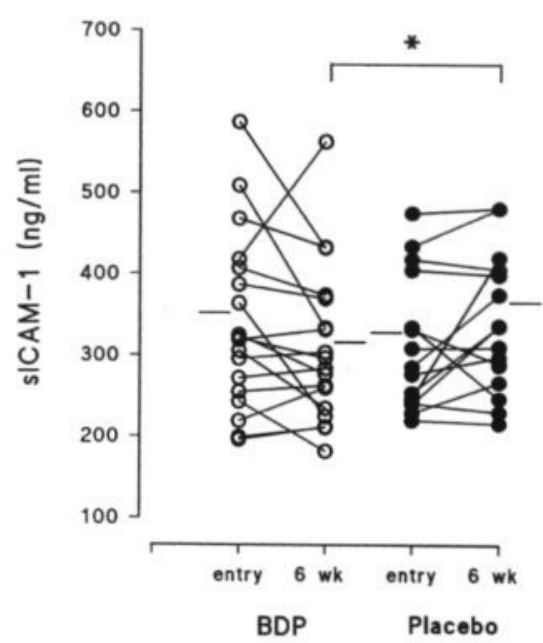

Figure 3. Beclomethasone dipropionate reduces levels of SICAM-1 after 6 weeks of treatment in patients with stable asthma. Horizontal bars represent the mean of the observed response $\left({ }^{\star} p<0.05\right)$.

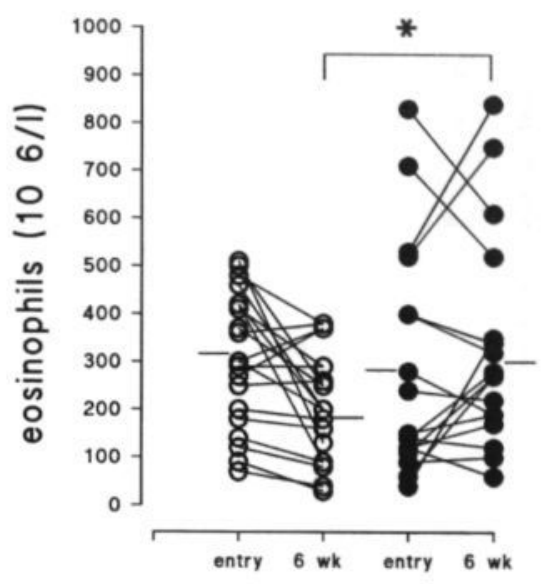

Figure 4. Beclomethasone dipropionate reduces the number of peripheral blood eosinophils in patients with stable asthma. Individual responses are shown after 6 weeks of treatment. Horizontal bars indicate the mean of the observed response $\left({ }^{\star} p<0.02\right.$ versus placebo).

number of eosinophils and IgE). A weak correlation was found for sICAM-1 and $\mathrm{FEV}_{1}$, although statistical significance was not reached $(\mathrm{r}=-0.30, \mathrm{p}=0.056)$. No further significant correlations could be observed between levels of inflammatory mediators and indicators of asthma severity.

We also investigated the correlation between sTNF-receptors and adhesion molecules, since correlations between sICAM-1 and sTNF-receptors have been reported in inflammatory disease $[19,20]$. Interestingly, we observed a weak correlation between sTNF-R55 and sICAM- $1(\mathrm{r}=0.27, \mathrm{p}=0.025)$, whereas no correlation was found for sTNF-R75 and sICAM-1.

Analysis of the effects of BDP on changes in both sTNF-R55 and sICAM-1 showed a significant correlation between BDP-induced changes in sTNF-R55 and levels of sTNF-R55 at entry of the study $(r=-0.56, p=0.014$, Fig. $5 a)$ and for sICAM-1 a similar correlation was found $(r=-0.53, p=0.025$, Fig. $5 b)$. Although at entry a weak correlation was observed between sICAM-1 and pulmonary function, effects of BDP on inflammatory mediators were not correlated with levels of pulmonary function, number of circulating eosinophils, IgE or levels of BHR; also, changes induced by BDP in number of peripheral blood eosinophils did not correlate with BDP-induced changes in inflammatory mediators. 


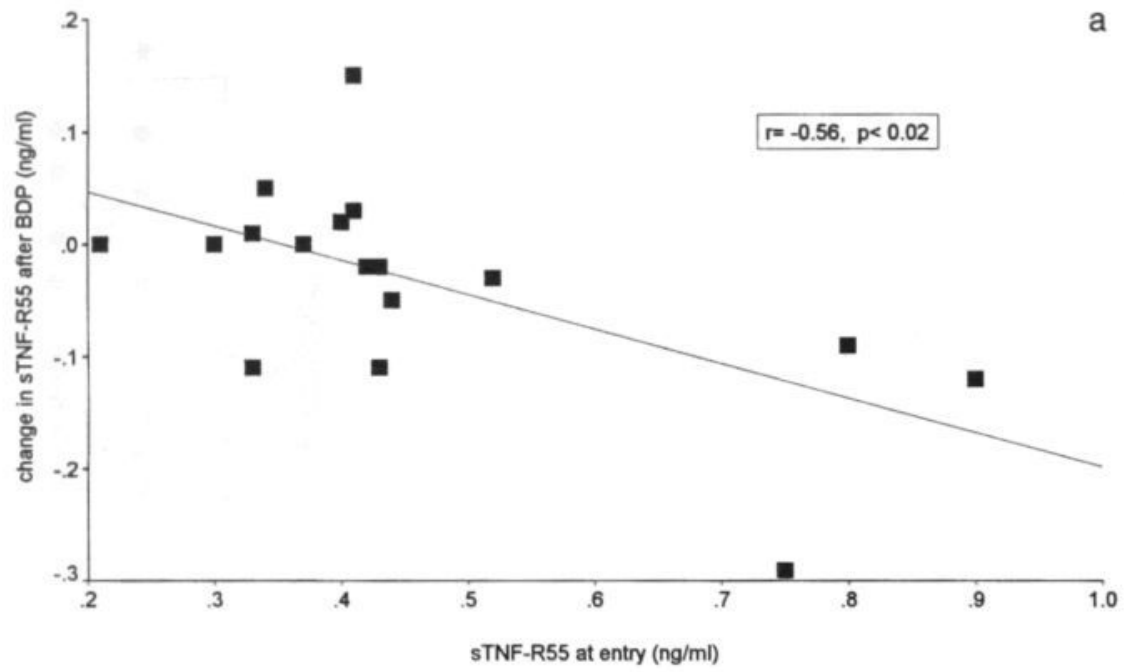

Figure 5a. A close correlation was observed between initials levels of sTNF-R55 and change in STNF-R55, induced by treatment with beclomethasone dipropionate in patients with stable asthma (Spearman rank correlation $\mathrm{r}=-0.56, \mathrm{p}<0.02$ ).

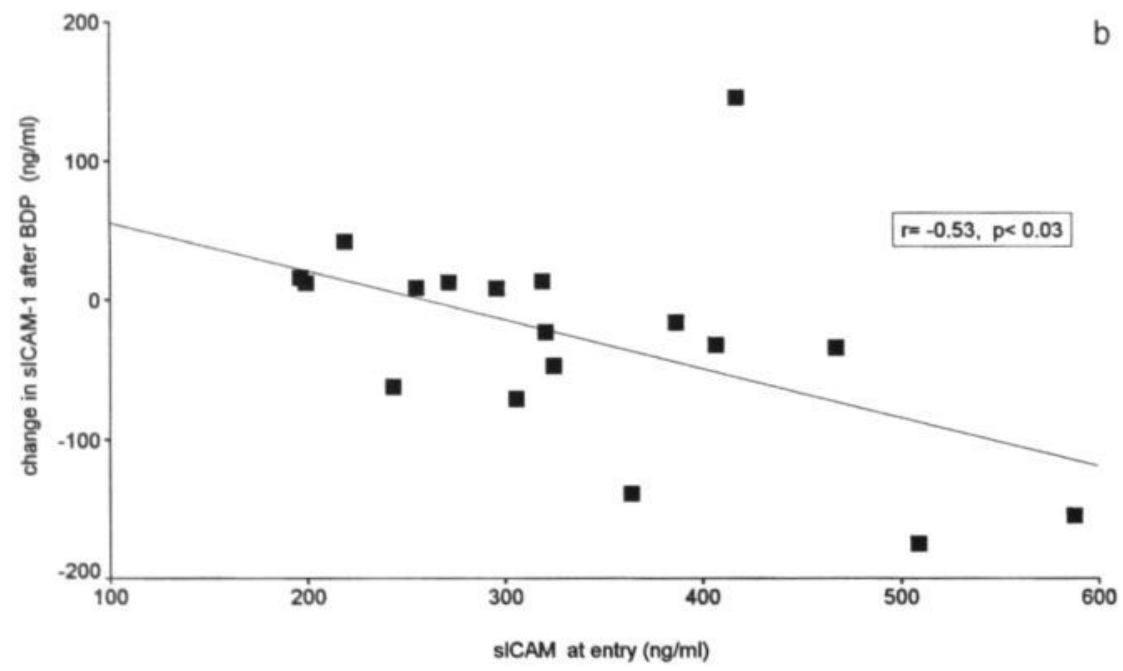

Figure 5b. Also, a close correlation was observed between levels of sICAM-1 at entry and change in sICAM-1 after 6 weeks of treatment with beclomethasone dipropionate in patients with stable asthma (Spearman rank correlation $r=-0.53, p<0.03$ ). 


\section{DISCUSSION}

In the present study beclomethasone dipropionate decreased levels of sTNF-R55 and sICAM-1 in clinically stable asthmatic patients. Levels of sTNF-R55 decreased after two weeks, whereas changes in sICAM-1 occurred after six weeks of treatment. BDP-induced changes in sTNF-R55 and sICAM-1 were significantly correlated with initial levels of sTNF-R55 and sICAM-1.

Cell adhesion molecules and TNF-receptors have been shown to be involved in the pathogenesis of asthma $[7,10,23]$. These cell adhesion molecules and TNFreceptors can be shed from the cellular surface and enhanced levels of these mediators have been detected in the general circulation during asthma attacks $[21,22,23,27]$. ICAM-1 is involved in the adhesion of neutrophils and eosinophils to endothelial cells and serves as a receptor for rhinovirus [10]. Cytokines like IL-1, IL-4, IFN- $\gamma$ and TNF $\alpha$ induce an upregulation of ICAM-1. In asthma, an increased expression of ICAM-1 has been observed following antigen challenge [9] but also in patients with stable disease [7]. Soluble forms of ICAM-1 have been isolated in healthy individuals and elevated levels of sICAM-1 have been observed in inflammatory disease $[18,19]$. These soluble forms of ICAM-1 may have a functional role in inhibiting cell adhesion to for instance endothelial cells. In the present study no differences were observed in levels of sICAM-1 between stable asthmatic patients and healthy controls, which is in agreement with previous studies $[21,22]$. BDP was shown in the present study to reduce levels of circulating ICAM-1 in stable asthmatic patients. This decrease was statistically significant after 6 weeks treatment, which might explain why in a prior study using corticosteroids no changes in sICAM-1 were observed during 4 weeks follow-up [21]. Interestingly, the magnitude of change in levels of sICAM-1 in the present study is comparable to the change in sICAM-1 following segmental allergen challenge [9]. Elevated levels of sICAM-1 have been described in exacerbations of asthma and levels of sICAM-1 decreased following oral corticosteroid therapy [27]. In the present study BDP decreased levels of sICAM-1 in stable asthmatic patients, whereas no changes were observed in sE-selectin. This observation may be explained by a decreased ICAM-1 expression in bronchial tissue or decreased shedding of ICAM-1 by BDP. Corticosteroids have been shown in vitro to decrease ICAM-1 expression on bronchial epithelial cells [4], endothelial cells [5], eosinophils [28], lymphocytes and macrophages [4]. Since we did not perform bronchial biopsies in this study, we can not provide a direct answer to BDP-induced changes in bronchial mucosa of the patients. BDP, in a dosage similar to the present study, has been shown in several bronchial biopsy studies to reduce bronchial inflammation in asthma [2,29]. Animal studies have demonstrated a role for ICAM-1 in the development of BHR in asthma $[30,31]$. Although in the present study no direct 
correlation was observed between changes in SICAM-1 and BHR, the present data support the involvement of ICAM-1 in the pathophysiology of asthma.

In the present study BDP also induced a small, but significant change in levels of sTNF-R55, whereas at baseline levels were not different between asthmatic patients and healthy volunteers. Soluble TNF-receptors are naturally occurring inhibitors of TNF $\alpha$ activity and have been isolated in serum and urine of healthy individuals [32]. Many of the inflammatory stimuli that induce TNF $\alpha$ production, also induce shedding of the TNF-receptors. Elevated levels of sTNF-receptors have been observed in clinical disease and levels decrease following treatment $[17,18,19]$. Data on the involvement of TNF-receptors in the pathophysiology of asthma are rare. Nasal epithelial cells of patients with allergic rhinitis were shown to express TNF-receptors whereas cells of healthy volunteers did not [33]. Data from the present study confirm observations in a previous study, which demonstrated that levels of circulating TNF-receptors in stable asthmatic children were comparable with healthy subjects [34]. In patients with unstable asthma, levels of both sTNF-R55 and -75 were elevated by $30-60 \%$, whereas treatment with systemic high dose corticosteroids resulted in normalization [23]. In the present study, BDP induced changes in levels of sTNF-R55 in patients with stable asthma, which has not been reported before. BDP reduced levels of sTNF-R55, whereas no changes occurred in levels of sTNF-R75, which is interesting since at entry of the study both TNF-receptor levels were closely related in all patients. The present study therefore suggests that inhaled corticosteroids may differentially influence TNF-receptor expression. Interestingly, in the present study levels of soluble TNF-R55 correlated with levels of sICAM-1 and changes in sTNF-R55 preceded changes in sICAM-1. Similar observations have been made in acute malaria [19], indicating that parallel changes may occur in different kinds of inflammatory disease.

BDP-induced changes in circulating inflammatory mediators in the present study were relatively small, but this may be explained by the stable mild asthmatic patients studied. It is therefore not surprising that we did not observe changes in asthma symptom scores and PEF variability. The observation of a decrease in number of circulating eosinophils in the present study may reflect decreased inflammation; however changes in circulating eosinophils did not reflect changes in BHR in another study [35]. Therefore the observed changes in circulating inflammatory mediators in the present study are interesting. We speculate that in accordance with other inflammatory diseases $[17,18,19]$ a decrease of sTNF-R55 and sICAM-1 in the general circulation may reflect decreased inflammation. The effect of BDP on circulating inflammatory mediators was more enhanced in patients with higher levels of inflammatory mediators, although no clear correlation 
could be observed between levels of inflammatory mediators and levels of asthma severity.

In the present study we can not exclude the possibility that BDP may have influenced levels of sICAM-1 and sTNF-R55 by a systemic effect, although arguments above favour an attenuation of local inflammation by BDP. BDP $800 \mu \mathrm{g} /$ day did not induce changes in urinary cortisol excretion in comparison to placebo [36], whereas in another study BDP up to $1600 \mu \mathrm{g} /$ day did not suppress the hypothalamic pituitary adrenal axis [37]. These data argue against a systemic effect of BDP in the dose used in the present study.

In conclusion, the present study demonstrated that treatment with BDP resulted in decreased levels of sICAM-1 and sTNF-R55 in stable asthmatic patients. The changes induced by BDP were correlated with initial levels of sTNF-R55 and sICAM-1, indicating that higher levels of inflammation respond more to antiinflammatory treatment. The present study suggests that changes in circulating ICAM-1 and TNF-R55 may reflect possible therapeutic actions of BDP on bronchial inflammation. The present data support a clinical role for non-invasive monitoring of bronchial inflammation in asthma.

\section{ACKNOWLEDGEMENTS}

We thank Celltech, Slough, United Kingdom for providing rh-sTNF-R55, rhsTNF-R75, rh-sICAM-1 and rh-sE-selectin used as standards in the immunoassays.

\section{REFERENCES}

1. Laitinen LA, Laitinen A, Haahtela H. A comparative study of the effects of an inhaled corticosteroid, budenoside, and a $B_{2}$-agonist, terbutaline, on airway inflammation in newly diagnosed asthma: a randomised double-blind, parallel-group controlled trial. J Allergy Clin Immmunol 1992; 90: 32-42.

2. Djukanovic R, Wilson JW,Britten KM, Wilson SJ, Walls AF, Roche WR, Howarth PH, Holgate ST. Effect of an inhaled corticosteroid on airway inflammation and symptoms in asthma. Am Rev Respir Dis 1992; 145: 669-674.

3. Pennings HJ, Wouters EFM. Effect of inhaled beclomethasone dipropionate on isocapnic hyperventilation with cold air in asthmatics, measured with forced oscillation technique. Eur Respir J 1997: 10: 665-671.

4. Van de Stolpe A, Caldenhove E, Raaijmakers JAM, Van der Saag PT, Koenderman L. Glucocorticoid-mediated repression of Intercellular Adhesion Molecule-1 expression in human monocytic and bronchial epithelial cell lines. Am J Respir Cell Mol Biol 1993; 8 : 340-347. 
5. Cronstein BN, Kimmel SC, Levin RI, Martiniuk F, Weissmann G. A mechanism for the antiinflammatory effects of corticosteroids: the glucocorticoid receptor regulates leucocyte adhesion to endothelial cells and expression of endothelial-leucocyte adhesion molecule-1 and intercellular adhesion molecule-1. Proc Natl Acad Sci USA 1992; 89: 9991-9995.

6. Vignola AM, Campbell AM, Chanez P, Bousquet J, Lacoste P, Michel F, Goddard P. HLA-DR and ICAM-1 expression on bronchial epithelial cells in asthma and chronic bronchitis. Am Rev Respir Dis 1993; 148: 689-694.

7. Gosset Ph, Tillie-Leblond I, Janin A, Marquette C-H, Copin M-C, Wallaert B, Tonnel A-B. Expression of E-selectin, ICAM-1 and VCAM-1 on bronchial biopsies from allergic and non-allergic asthmatic patients. Int Arch Allergy Immunol 1995; 106: 69-77.

8. Louis R, Shute J, Biagi S, Stanciu L, Marelli F, Tenor H, Hidi R, Djukanovic R. Cell infiltration, ICAM-1 expression, and eosinophil chemotactic activity in asthmatic sputum. Am J Respir Crit Care Med 1997; 155: 466-472.

9. Takahashi N, Liu MC, Proud D, Yu XY, Hasegawa S, Spannhake EW. Soluble intercellular adhesion molecule 1 in bronchoalveolar lavage fluid of allergic subjects following segmental antigen challenge. Am J Respir Crit Care Med 1994; 150: 704-709.

10. Montefort S, Holgate ST, Howarth PH. Leucocyte-endothelial adhesion molecules and their role in bronchial asthma and allergic rhinitis. Eur Respir J 1993; 6: 1044-1054.

11. Leeuwenberg JFM, Smeets EF, Neefjes JJ, Schaffer MA, Cinek T, Jeunhomme TMMA, Ahern TJ, Buurman WA. E-Selectin and intercellular adhesion molecule-1 are released by activated human endothelial cells in vitro. Immunol 1992; 77: 543-549.

12. Broide DH, Lotz M, Cuomo AJ, Coburn DA, Federman EC, Wasserman SI. Cytokines in symptomatic asthma airway. J Allergy Clin Immunol 1992; 89: 958-967.

13. Gosset P, Tsicopoulos A, Wallaert B, Joseph M, Capron A, Tonnel AB. Tumor necrosis factor alpha and interleukin- 6 production by human mononuclear phagocytes from allergic asthmatics after IgE-dependent stimulation. Am Rev Respir Dis 1992; 146: 768-774.

14. Virchow J-C jr, Walker C, Hafner D, Kortsik C, Werner P, Matthys H, Kroegel C. T cells and cytokines in bronchoalveolar lavage fluid after segmental allergen provocation in atopic asthma. Am J Respir Crit Care Med 1995; 151: 960-968.

15. Keatings VM, O'Connor BJ, Wright LG, Huston DP, Corrigan CJ, Barnes PJ. Late response to allergen is associated with increased concentrations of tumor necrosis factor- $\alpha$ and IL- 5 in induced sputum. J Allergy Clin Immunol 1997; 99: 693-698.

16. Van Zee KJ, Kohno T, Fischer E, Rock CS, Moldawer LL, Lowry SF. Tumor necrosis factor soluble receptors circulate during experimental and clinical inflammation and can protect against excessive tumor necrosis factor $\alpha$ in vitro and in vivo. Proc Natl Acad Sci 1992; 89: 4845-4849.

17. Studnicka-Benke A, Steiner G, Petera P, Smolen JS. Tumour necrosis factor alpha and its soluble receptors parallel clinical disease and autoimmune activity in systemic lupus erythematosus. Br J Rheumatol 1996; 35: 1067-1074.

18. Rieckmann P, Martin S, Weichselbraun I, Albrecht M, Kitze B, Weber T, Tumani H, Broocks A, Lüer W, Helwig A, Poser S. Serial analysis of circulating adhesion molecules and TNF receptor in serum from patients with multiple sclerosis: CICAM-1 is an indicator for relapse. Neurology 1994; 44: 2367-2372.

19. Wenisch C, Varijanonta S, Looareesuwan S, Graninger W, Pichler R, Wernsdorfer W. Soluble intercellular adhesion molecule-1 (ICAM-1), Endothelial leucocyte adhesion molecule-1 (ELAM-1), and tumor necrosis factor receptor ( $55 \mathrm{kDa}$ TNF-R) in patients with acute Plasmodium Falciparum malaria. Clin Immunol Immunopathol 1994; 71: 344-348.

20. Viac J, Vincent C, Palacio S, Schmitt D, Claudy A. Tumour necrosis factor(TNF) soluble receptors in malignant melanoma: correlation with soluble ICAM-1 levels. Eur J Cancer 1996; 32A: 447-449. 
21. Montefort S, Lai CKW, Kapai P, Leung J, Lai KN, Chan HS, Haskard DO, Howarth PH, Holgate ST. Circulating adhesion molecules in asthma. Am J Respir Crit Care Med 1994; 149: 1149-1152.

22. Kobayashi T, Hashimoto S, Imai K, Amemiya E, Yamaguchi M, Yachi A, Horie T. Elevation of serum soluble intercellular adhesion molecule-1 (sICAM-1) and SE-selectin levels in bronchial asthma. Clin Exp Immunol 1994; 96: 110-115.

23. Yoshida S, Hashimoto S, Nakayama T, Kobayashi T, Koizumi A, Horie T. Elevation of serum soluble tumour necrosis factor (TNF) receptor and IL-1 receptor antagonist levels in bronchial asthma. Clin Exp Immunol 1996; 106: 73-78.

24. Leeuwenberg JFM, Jeunhomme TMAA, Buurman WA. Slow release of soluble TNF receptors by monocytes in vitro. J Immunol 1994; 152: 4036-4043.

25. Bouma MG, Laan MP, Dentener MA, Buurman WA. Analysis of soluble adhesion molecules. In: Johnstone AP, Turner MW. Immunochemistry 2: A practical approach. Oxford, Oxford University Press, 1997; 181-196.

26. Schouten HJA. Klinische statistiek, een practische inleiding in methodologie en analyse. Houten, Bohn, Stafleu. Van Loghum, 1995; 87-106.

27. Shioto Y, Wilson JG, Marukawa M, Ono T, Kaji M. Soluble intercellular adhesion molecule 1 (ICAM-1) antigen in sera of bronchial asthmatics. Chest 1996; 109: 94-99.

28. Hansel TT, Braunstein JB, Walker C, Blazer K, Bruijnzeel PLB. Sputum eosinophils from asthmatics express ICAM-1 and HLA-DR. Clin Exp Immunol 1991; 86: 271-277.

29. Montefort S, Roche WR, Howarth PH, Djukanovic R, Gratziou C, Caroll M, Smith L, Britten KM, Haskard D, Lee TH, Holgate TH. Intercellular adhesion molecule -1(ICAM-1) and endothelial leucocyte adhesion molecule-1 (ELAM-1) expression in the bronchial mucosa of normal and asthmatic subjects. Eur Respir J 1992; 5: 815-823.

30. Wegner CD, Gundel RH, Reilly P, Haynes N, Letts LG, Rothlein R. Intercellular adhesion molecule-1 (ICAM-1) in the pathogenesis of asthma. Science 1990; 247: 456-459.

31. Buckley TL, Bloemen PGM, van den Tweel MC, Henricks PAJ, Van den Tweel MC, Redegeld FAM, Koster AS, Nijkamp FP. LFA-1 and ICAM-1 are crucial for the induction of hyperreactivity in the mouse airways. Ann N Y Acad Sci 1996; 796: 149-161.

32. Aderka D, Engelmann H, Shemer-Avni Y, Hornik V, Galil A, Sarov B, Wallach D. Variation in serum levels of the soluble TNF-receptors among healthy individuals. Lymphokine Cytokine Res 1992; 11: 157-159.

33. Nonaka M, Nonaka R, Jordana M, Dolovich J. GM-CSF, IL-8,IL-1R, TNF $\alpha-R$, and HLA-DR in nasal epithelial cells in allergic rhinitis. Am J Respir Crit Care Med 1996; 153: 1675-1681.

34. Laan MP, Koning H, Baert MRM, Oranje AP, Buurman WA, Savelkoul HFJ, Neijens HJ. Levels of soluble intercellular adhesion molecule-1, soluble E-selectin, tumor necrosis factor- $\alpha$, and soluble tumor necrosis factor receptor p55 and p75 in atopic children. Allergy 1998; 53: 51-58.

35. Evans PM, O'Connor BJ, Fuller RW, Barnes PJ, Chung KF. Effect of inhaled corticosteroids on peripheral blood eosinophil counts and density profiles in asthma. J Allergy Clin Immunol 1993; 91: 643-650.

36. Mcintyre HD, Mitchell CA, Bowler SD, Armstrong JG, Wooler JA, Cowley DM. Measuring the systemic effects of inhaled beclomethasone: timed morning urine collections compared with 24 hour specimens. Thorax 1995; 50: 1280-1284.

37. Boe J, Bakke P, Rodolen T, Skovlund E, Gulsvik A. High-dose inhaled steroids in asthmatics: moderate efficacy gain and supression of the hypothalamic-pituitary-adrenal (HPA) axis. Eur Respir J 1994; 7: 2179-2184. 



\section{Changes in levels of catalase and glutathione in erythrocytes of patients with stable asthma, treated with beclomethasone dipropionate}

H.J. Pennings', P.J.A. Borm", C.T.A. Evelo "', E.F.M. Wouters'.

From the Department of Pulmonology, University Hospital Maastricht, Department of Health Risk Analysis and Toxicology" and Department of Pharmacology "', Maastricht University, Maastricht, The Netherlands. 


\section{SUMMARY}

Reactive oxygen species (ROS) are involved in the pathophysiology of the asthmatic inflammatory response. In asthmatic patients, antioxidant defense is decreased, leading to an oxidant-antioxidant imbalance. Although inhaled corticosteroids decrease asthmatic inflammation and modulate ROS generation, little is known of their effect on cellular antioxidant levels. Aim of the present study was to evaluate the effect of 6 weeks treatment with inhaled beclomethasone dipropionate (BDP) $\left(1000 \mu \mathrm{g}\right.$.day $\left.{ }^{-1}\right)$ on erythrocyte antioxidant levels in stable asthmatic patients.

40 Patients with stable, mild asthma were treated in a double-blind, placebocontrolled, parallel-group study with beclomethasone dipropionate $250 \mu \mathrm{g} 2$ puffs b.i.d. for 6 weeks. At entry and every 2 weeks during treatment erythrocyte antioxidant levels, hematology parameters, pulmonary function tests and asthma-symptoms were determined.

Results show that during treatment with BDP erythrocyte catalase levels increased (at entry (mean \pm SEM) $41 \pm 4$, after 6 weeks $54 \pm 4 \mu \mathrm{mol} \mathrm{H}_{2} \mathrm{O}_{2} \cdot \mathrm{min}^{-1} \cdot \mathrm{g}^{-1} \mathrm{Hb}$, $\mathrm{p}=0.05$ in comparison with placebo). An inverse correlation existed between erythrocyte catalase levels at entry of the study and changes in erythrocyte catalase after BDP treatment. Erythrocyte total glutathione levels significantly decreased after 6 weeks treatment with BDP (from $7.0 \pm 0.4$ to $6.6 \pm 0.3 \mu \mathrm{mol} . \mathrm{g}^{-1} \mathrm{Hb}$ ( $\mathrm{p}=$ $0.04)$ ). Blood eosinophil counts were higher in patients, responding with an increase in erythrocyte catalase levels during BDP treatment, than in patients, not responding with an increase in catalase levels during treatment with BDP ((mean \pm SEM) $340 \pm 39$ respectively $\left.153 \pm 52 \times 10^{6} \cdot \mathrm{L}^{-1}, \mathrm{p}=0.05\right)$.

The present study shows that treatment with inhaled BDP results in changes in antioxidants levels in erythrocytes of patients with stable, mild asthma.

\section{INTRODUCTION}

Asthma is characterized by reversible airflow obstruction and the presence of a chronic inflammation within the airways. Cells involved in the inflammatory process in asthma have been shown to generate increased amounts of reactive oxygen species (ROS) $[1,2,3]$ and levels of ROS generation correlate with asthma severity [4]. ROS-generation is enhanced in BAL-cells of stable asthmatics [5] and increases after antigen challenge [6]. ROS can influence airway cell function by interacting with DNA, altering protein structures, interfering with signal transduction mechanisms by oxidative modification (e.g. $\beta_{2}$-adrenergic receptors), contracting airway smooth muscle, increasing vascular permeability and increasing release of secondary inflammatory mediators (i.e. leukotrienes, platelet- 
activating factor) [7]. Within the lung powerful antioxidant enzymes are present, both intra- and extracellularly, and levels of these enzymes may increase following chronic exposure to increased levels of ROS [8,9]. Levels of glutathione have been shown to be elevated in bronchoalveolar lavage fluid of patients with stable asthma [10]. In asthma, ROS generation is not only increased within the pulmonary compartment, but also in peripheral blood cells $[1,3]$. This observation is in line with data showing the presence of activated leucocytes in the general circulation after allergen challenge [11]. In asthma, evidence for a disturbed oxidant-antioxidant balance has been found in the general circulation. Decreased glutathione peroxidase levels have been reported in serum, platelets and red blood cells (RBC) $[12,13]$ and levels of selenium, a co-factor for glutathione-peroxidase, are reduced in asthmatic patients [13]. Decreased levels of catalase in RBC of asthmatic children have also been reported [14]. Recently, it was shown that antioxidant capacity is decreased in plasma of asthmatic patients, both in stable and in acute asthma [15].

Red blood cells can be regarded as circulating antioxidant carriers, reflecting exposition to ROS $[9,16]$. The importance of RBC antioxidant enzymes in protecting target cells from ROS has been shown in both in vitro [17] and in vivo [18] studies. $\mathrm{RBC}$ antioxidative enzymes can be determined with a high degree of reproducibility and studies have shown that wide interindividual variations exist [19]. Since $\mathrm{RBC}$ are more easily accessible than lung tissue, $\mathrm{RBC}$ antioxidant levels have been used in studies evaluating chronic ROS exposure [16,20,21].

Corticosteriods play a dominant role in the treatment of asthma due to their powerful anti-inflammatory effects [22]. So far, few studies have evaluated the effects of inhaled corticosteroids on antioxidant levels in asthma [23]. Aim of the present study was to evaluate the influence of inhaled beclomethasone dipropionate (BDP) on antioxidant levels of RBC in patients with mild, stable asthma. We chose to study changes in $\mathrm{RBC}$, since they represent a long term index of antioxidant status [16]. The present study shows that treatment with BDP results in an increase in levels of $\mathrm{RBC}$ catalase, whereas for total $\mathrm{RBC}$ glutathione a reduction was observed. The study suggests that these changes may be explained by effects of inhaled steroids on airway inflammation with subsequent changes in systemic antioxidant levels.

\section{MATERIAL AND METHODS}

Study design

The present study was performed simultaneously with investigations into the effect of beclomethasone dipropionate on isocapnic hyperventilation with cold air, 
the results of which have been reported elsewhere [24]. 40 Patients with mild stable asthma, equally distributed over both sexes, were included in the study. Study design consisted of a double-blind, placebo-controlled, parallel-group study, in which patients were randomly allocated to receive either beclomethasone dipropionate $250 \mu \mathrm{g} /$ puff 2 puffs b.i.d. by metered dose inhaler or placebo for six weeks. The time schedule consisted of a run-in period of 1 week followed by a treatment period of 6 weeks, during which control visits were scheduled every 2 weeks. All patients entering the study had a documented bronchial hyperresponsiveness (defined as a $\mathrm{PD}_{20}$ value to histamine lower than $8 \mu \mathrm{mol}$ ) and were all atopic, with a mean number of positive skin tests for aero-allergens of $4.4 \pm 2.4$ (mean $\pm \mathrm{SD}$ ).

Patients were all in a clinically stable condition and showed no evidence of recent respiratory tract infection. None of the patients had been treated with inhaled or oral corticosteroids within three months prior to the study. Only $\beta_{2}$-sympaticomimetic drugs were allowed for control of asthma.

During the study, patients recorded in a diary asthma-symptoms $(0=$ no complaints to $5=$ major interference with daily activities), the number of $\beta_{2}$-sympaticomimetic drugs used for control of asthma and peak expiratory flow rates (PEFR), using mini-Wright peak-flow meters (Airmed, Clement Clarke international Ltd., London, England). Patients recorded the best of three successive measurements of PEFR in the morning and the evening. At every visit, the patient diary was reviewed and pulmonary function was evaluated by flow-volume measurements using a pneumotachograph (Masterlab, Jaeger $\mathrm{GmbH}$, Würzburg, FRG).

The study was approved by the local medical ethical committee and written informed consent was obtained from all patients.

\section{Chemicals}

The following chemicals were used: superoxide dismutase (SOD, bovine erythrocytes), xanthine oxidase (cow milk) and glutathione reductase (yeast), $\mathrm{NADPH}$ and reduced (GSH) and oxidized (GSSG) glutathione (Boehringer Mannheim, Mannheim, Germany); xanthine, cytochrome C, hemoglobin, sodium azide and $\alpha$-tocopherol (Merck, Darmstadt, Germany); $N$-Ethylmaleimide and 0-phthaldialdehyde (Aldrich, Steinheim, Germany); 1-chloro-2,4-dinitrobenzene (CDNB), glutathione reductase (type III)(GR) and reduced $\beta$-nicotinamide (NADPH) (Sigma, St. Louis, Mo, USA). All other chemicals used were of analytical quality. Only microfiltrated deionized water was used. 
Venous blood ( $15 \mathrm{ml}$ ) was collected in EDTA-coated tubes (Sherwood Medical, Balleymoney, N-Ireland). White blood cell counts, cell-differentiation as well as quantification of eosinophils was performed. For antioxidant analysis, blood was immediately stored at $4^{0} \mathrm{C}$ after collection and processed within 2 hours. Subsequently blood was centrifuged for $10 \mathrm{~min}$., $3000 \mathrm{rpm}$ at $4^{0} \mathrm{C}$. The buffy coat and plasma was removed and $\mathrm{RBC}$ were washed with $10 \mathrm{~mL}$ phosphate buffered saline (PBS), gently swaying the tube and afterwards $\mathrm{RBC}$ were centrifuged again for 10 $\mathrm{min}, 3000 \mathrm{rpm}$ at $4^{0} \mathrm{C}$. This procedure was repeated three times. After the washing procedure, samples were frozen in aliquots of $1 \mathrm{~mL}$ at $-70^{\circ} \mathrm{C}$ until analysis. Glutathione-peroxidase, superoxide dismutase and catalase activity were determined as described previously [20]. Hemoglobin was determined according to the method of van Kampen and Zijlstra [25]. In short, for glutathione peroxidase 1 $\mathrm{mL}$ of hemolysate was mixed with an equal volume of potassium ferricyanide and $\mathrm{KCN}$ containing buffer. $50 \mu \mathrm{L}$ of the mixture was added to the incubation buffer containing $1 \mathrm{mM} \mathrm{GSH}, 200 \mu \mathrm{M} \mathrm{NADPH}$ and $1 \mathrm{IU} \cdot \mathrm{mL}^{-1}$ GSSG-reductase and the rate of oxidation of $\mathrm{NADPH}$ was followed for $3 \mathrm{~min}$ by spectrophotometry at $340 \mathrm{nM}$. Substrates used were $0.33 \mathrm{mM} \mathrm{H}_{2} \mathrm{O}_{2}$ for measurement of Se-dependent GSH-Px. Units of enzyme activity were expressed as $\mu$ mol NADPH.min ${ }^{-1} \cdot \mathrm{g}^{-1}$ hemoglobin using a molar extinction coefficient for NADPH of 6.22 $\mathrm{x} 10^{-3} \cdot \mathrm{mM}^{-1} \cdot \mathrm{cm}^{-1}$.

Superoxide Dismutase activity was measured by the method of McCord and Fridovich. A standard curve was prepared using commercially available SOD. The enzyme activity at $25^{\circ} \mathrm{C}$ was expressed in units enzyme per mg hemoglobin.

Catalase-activity was measured according to Aebi, as described before. Prior to the

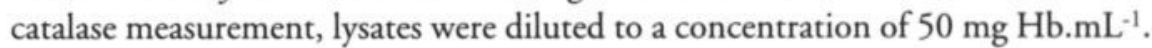
At $25^{\circ} \mathrm{C} 4 \mu \mathrm{L}$ lysate and $1 \mathrm{~mL} \mathrm{H}_{2} \mathrm{O}_{2}(30 \mathrm{mM})$ were added to $2 \mathrm{~mL}$ PBS. The rapid decomposition of $\mathrm{H}_{2} \mathrm{O}_{2}$ was followed during $15 \mathrm{sec}$ from the decrease in absorbance at $240 \mathrm{~nm}$. Enzyme activity was expressed as $\mu \mathrm{mol} \mathrm{H}_{2} \mathrm{O}_{2} \cdot \mathrm{min}^{-1} \cdot \mathrm{g}^{-1}$ hemoglobin using a molar extinction coefficient for $\mathrm{H}_{2} \mathrm{O}_{2}$ of $0.0394 . \mathrm{mM}^{-1} \cdot \mathrm{cm}^{-1}$.

Total glutathione (reduced plus oxidized) and glutathione S-transferase were determined as described previously [21]. In short, for determination of total glutathione, RBC were treated with an equal volume of $10 \%(\mathrm{w} / \mathrm{v})$ trichloroacetic acid. Supernatants were diluted 9 fold with $100 \mathrm{mM}$ sodium/potassium buffer ( $\mathrm{pH} 7.4$ ) and measured using the cyclic oxidation-reduction method essentially as described by Andersen.

For determination of glutathione S-transferase activity (EC 2.5.1.18) with CDNB as substrate, full lysis of the thawed cells was induced with 5 volumes of ice-cold water (10-15 min), using the method of Habig and Jacoby with previously described modifications. 


\section{STATISTICS}

All data described are mean \pm SEM, unless otherwise specified. Effect of treatment was expressed as changes from baseline. Since antioxidant enzyme levels were not normally distributed, non-parametric tests were used for analysis between treatment groups (Mann-Whitney U test). A p-value lower than 0.05 was considered statistically significant (two-sided test). Correlations between parameters were evaluated using Spearman rank correlation coefficient. The statistical package SPSS/PC+ (version 6.1-Windows, SPSSInc., Chicago, IL, USA) was used for all calculations.

\section{RESULTS}

40 Patients were included in the study. Demographic variables are given in Table 1. As reported previously, patients in the BDP-group demonstrated a significantly higher $\mathrm{FEV}$, than the placebo group ( 101 versus $92 \%$ predicted, $\mathrm{p}=0.02$ ). $18 \mathrm{~Pa}$ tients in the BDP-group and 17 patients in the placebo group completed the study. In the placebo-group the main reason for dropping-out was withdrawal of consent ( 3 patients), whereas in the BDP-group exacerbation of eczema, necessitating oral corticosteroid treatment (1 patient) and non-compliance (1 patient) were the reasons for exclusion from the study.

At baseline, no differences in RBC antioxidant enzymes were observed between groups (Table 2). In the BDP-group, catalase levels could not be determined for 2 patients due to technical reasons. Smoking patients were equally distributed between groups (Table 1); no differences in antioxidant levels were observed between smokers and non-smokers (data not shown). Furthermore, no differences were observed in hemoglobin, white blood cell count and total number of eosinophils between groups (Table 1). At entry, for the whole group a significant correlation was observed between levels of glutathione peroxidase and glutathione Stransferase $(r=0.51, p=0.001)$ and also for glutathione peroxidase and SOD $(r=$ $-0.54, p<0.001$ ). No significant correlations were observed between levels of antioxidant enzymes and baseline pulmonary function, levels of bronchial hyperresponsiveness, IgE or white blood cell parameters.

During treatment with BDP, a gradual increase in RBC catalase activity was observed, which reached statistical significance after 6 weeks (at entry (mean \pm SEM) $41 \pm 4 \mu \mathrm{mol} \mathrm{H} \mathrm{O}_{2} \cdot \mathrm{min}^{-1} \cdot \mathrm{g}^{-1} \mathrm{Hb}$, after 6 weeks $54 \pm 4 \mu \mathrm{mol} \mathrm{H}{ }_{2} 0_{2} \cdot \mathrm{min}^{-1} \cdot \mathrm{g}^{-1} \mathrm{Hb}$, $\mathrm{p}=0.05$ ) (Fig. 1a and 2a). Interestingly, for total RBC glutathione an opposite change was observed; during BDP treatment, a gradual decrease in total glutathione levels was observed, which also reached statistical significance after 6 weeks treatment (at entry (mean \pm SEM) $7.0 \pm 0.4 \mu$ mol.g ${ }^{-1} \mathrm{Hb}$, at 6 weeks $6.6 \pm 0.3 \mu$ mol.g ${ }^{-1}$ 
Table 1. Subject characteristics Anthropometric and spirometric data (Mean \pm S.D.)

\begin{tabular}{lll}
\hline & BDP-group & Placebo \\
\hline M/F & $10 / 10$ & $10 / 10$ \\
Smoking (yes/no) & $4 / 16$ & $4 / 16$ \\
Age $(\mathrm{yr})$ & $29 \pm 7$ & $28 \pm 6$ \\
Height $(\mathrm{cm})$ & $172 \pm 7$ & $172 \pm 12$ \\
Weight $(\mathrm{kg})$ & $75 \pm 12$ & $74 \pm 14$ \\
FEV $(\%$ pred.) & $101 \pm 12^{\star}$ & $92 \pm 12$ \\
PD $_{20}$ histamine $(\mu \mathrm{mol})$ & $1.3 \pm 1.3$ & $1.1 \pm 1.9$ \\
Hemoglobin $\left(\mathrm{mmol} . \mathrm{L}^{-1}\right)$ & $8.7 \pm 0.6$ & $9.1 \pm 0.8$ \\
Leucocytes $\left(\times 10^{9} . \mathrm{L}^{-1}\right)$ & $6.3 \pm 2.0$ & $7.1 \pm 2.0$ \\
Eosinophils $\left(\times 10^{6} \cdot \mathrm{L}^{-1}\right)$ & $318 \pm 148$ & $298 \pm 229$ \\
IgE (kU.L.') & $430 \pm 519$ & $516 \pm 911$ \\
\hline
\end{tabular}

No significant differences were observed between both groups of asthmatic patients, except for $\mathrm{FEV}_{1}$, which was at baseline significantly higher in the BDP-group ( ${ }^{\star} \mathrm{p}=0.02$ ).

Table 2. Baseline RBC antioxidant levels in asthmatic patients

\begin{tabular}{|c|c|c|}
\hline & BDP & Placebo \\
\hline SOD (U.mg' Hb) & $1.14 \pm 0.09$ & $1.28 \pm 0.10$ \\
\hline GSH-Px (U.mg-1 Hb) & $3.27 \pm 0.38$ & $2.96 \pm 0.28$ \\
\hline GST $\left(\mathrm{U} . \mathrm{g}^{-1} \mathrm{Hb}\right)$ & $1.94 \pm 0.14$ & $1.85 \pm 0.15$ \\
\hline $\begin{array}{l}\text { Catalase } \\
\left(\mu \mathrm{mol} \mathrm{H}_{2} \mathrm{O}_{2} \cdot \mathrm{min}^{-1} \cdot \mathrm{g}^{-1} \mathrm{Hb}\right)\end{array}$ & $41.1 \pm 3.7$ & $47.1 \pm 3.3$ \\
\hline $\begin{array}{l}\text { total Glutathione } \\
\left(\mu \mathrm{mol} . \mathrm{g}^{-1} \mathrm{Hb}\right)\end{array}$ & $7.01 \pm 0.35$ & $6.27 \pm 0.25$ \\
\hline
\end{tabular}

At baseline, no significant differences were observed between the two groups of asthmatic patients. SOD: superoxide dismutase; GSH-Px: glutathione peroxidase; GST: glutathione S- transferase.

$\mathrm{Hb}, \mathrm{p}=0.04$ ) (Fig. $1 \mathrm{~b}$ and $2 \mathrm{~b}$ ). No correlation was present between changes in catalase and total glutathione in RBC. However, the increase of RBC catalaseactivity during treatment with BDP showed a weak correlation with the initial level of $\mathrm{RBC}$ catalase activity $(\mathrm{r}=-0.51, \mathrm{p}=0.04)$. For changes in total glutathione, a similar trend was detected, although statistically not significant $(r=-0.42$, $\mathrm{p}=0.08$ ). BDP-induced changes in levels of catalase or glutathione were not correlated with pulmonary function, level of bronchial hyperresponsiveness or IgE. However, when the BDP-group was divided in responders (increase in catalase at 6 weeks) and non-responders (stable or decreased catalase), a significant difference was observed between the two groups in the number of eosinophils at entry 
a
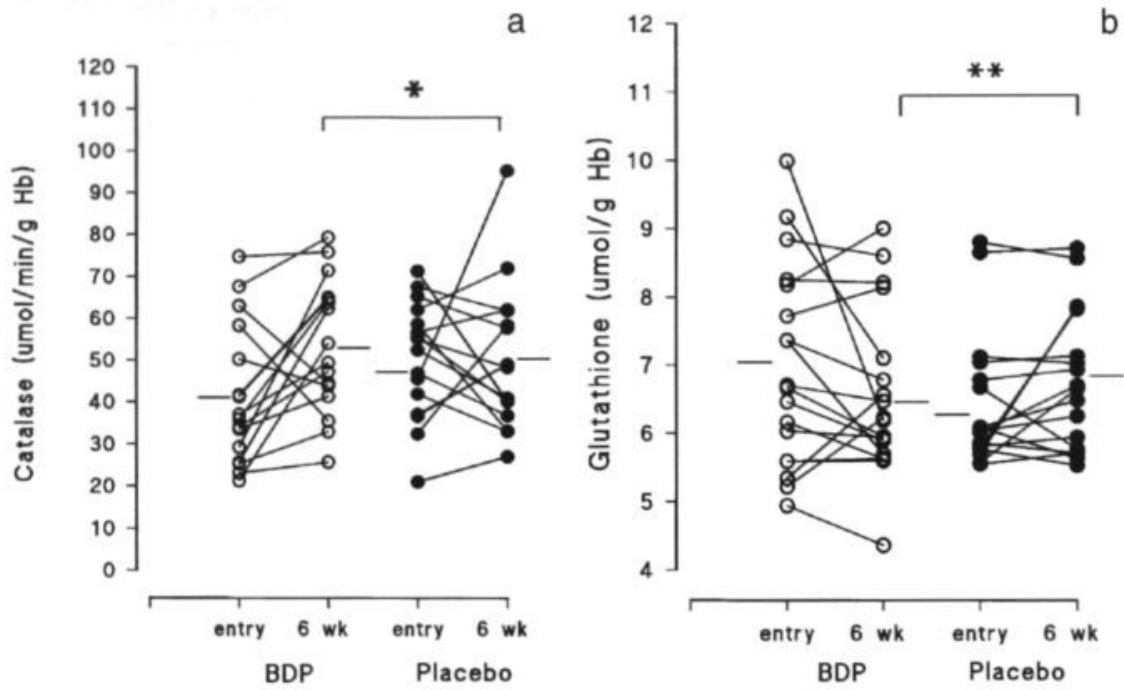

Figure 1. Beclomethasone dipropionate $\left(1000 \mu\right.$ g.day $\left.{ }^{-1}\right)$ induces a:) a significant rise in RBC catalase levels and b:) a decrease in RBC glutathione levels of stable asthmatic patients after 6 weeks treatment. Individual responses after 6 weeks treatment are shown for the BDP- and placebo-treated patients. Horizontal bars represent the mean of the observed response. ${ }^{*}: p=0.05 ;{ }^{\star \star}: p=$ 0.04 .
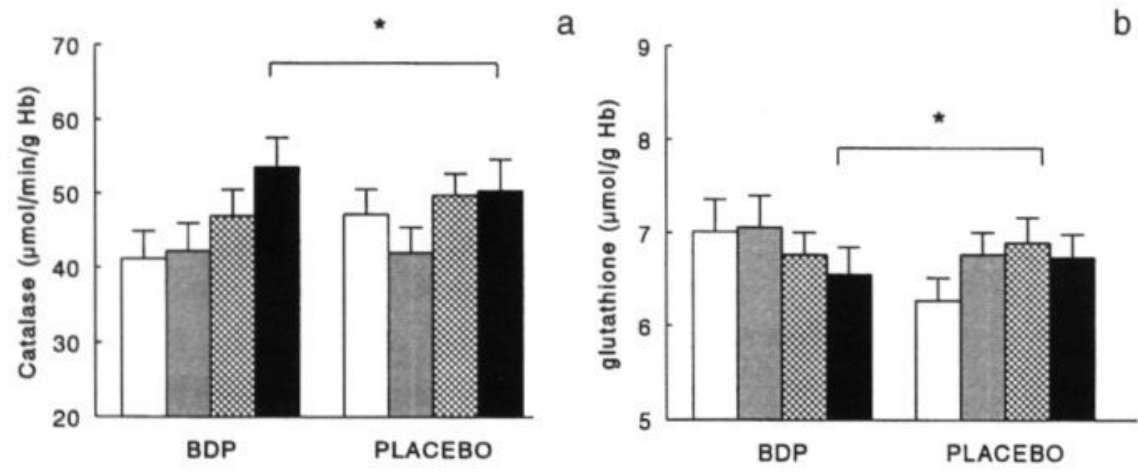

Figure 2. Changes in time in a:) RBC catalase and b:) RBC glutathione in stable asthmatic patients, treated for 6 weeks with beclomethasone dipropionate $1000 \mu$ g. day ${ }^{-1}$. Bars indicate mean \pm SEM of the two treatment groups at entry (open bars), after two weeks (hatched bars), four weeks (crosshatched bars) and after six weeks (solid bars). After 6 weeks, a significant difference was observed between groups for catalase $(*: p=0.05)$ and for glutathione $(*: p=0.04)$. 


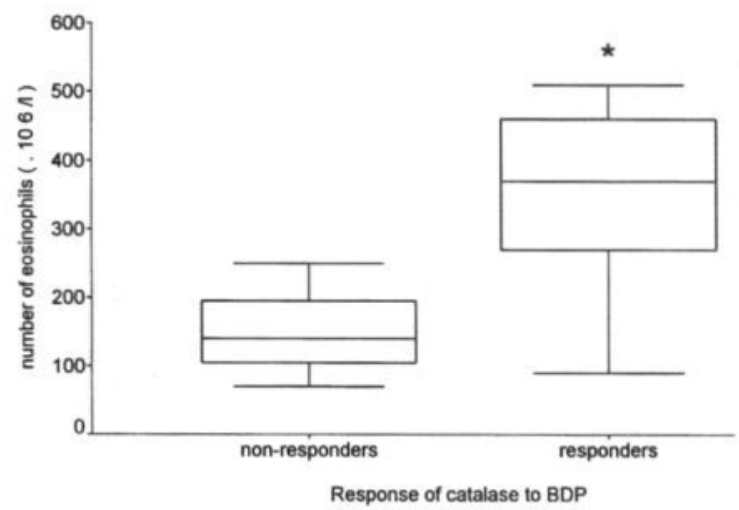

Figure 3. Boxplots showing that the number of peripheral blood eosinophils in responders (patients responding with a rise in RBC catalase after BDP-treatment, $n=13$ ) was significantly higher than in non-responders (i.e. stable or decreased catalase levels, $n=3$ ). Boxes indicate interquartile range, the horizontal line indicates the median. ${ }^{\star}: p=0.05$.

(number of eosinophils at entry in non-responders (mean \pm SEM) $153 \pm 52 \mathrm{x}$ $10^{6} . \mathrm{L}^{-1}$ versus responders $340 \pm 39 \times 10^{6} . \mathrm{L}^{-1}, \mathrm{p}=0.05$, Fig. 3). No differences in pulmonary function, airway hyperresponsiveness or baseline antioxidant levels were present between responders and non-responders. For glutathione, no differences in number of eosinophils could be observed between responders and nonresponders.

Activities of SOD, GSH-Px and GST did not change during treatment with BDP (data not shown). Also, during treatment with BDP no significant changes were observed in asthma symptom-scores, use of $\beta_{2}$-rescue medication and pulmonary function, as reported before [24].

During treatment with BDP, a significant decrease was observed in the total number of eosinophils in peripheral blood; this decrease was already observed after 2 weeks of treatment (at entry (mean \pm SEM) $318 \pm 33 \times 10^{6} \cdot \mathrm{L}^{-1}$; after 2 weeks BDP $228 \pm 31 \times 10^{6} . \mathrm{L}^{-1} ; \mathrm{p}<0.02$ between groups) and number of eosinophils remained well below baseline-levels during the rest of the study period (Fig. 4). 


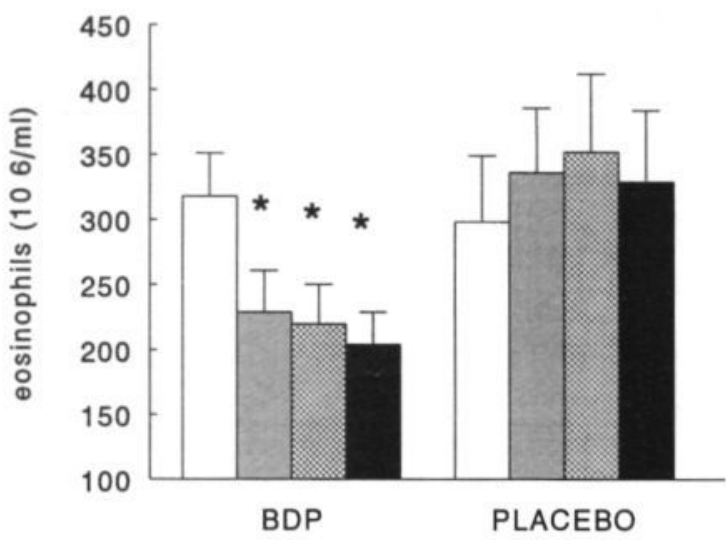

Figure 4. Beclomethasone dipropionate induces a significant decrease in number of circulating eosinophils in stable asthmatic patients. Bars indicate mean \pm SEM of number of blood eosinophils during treatment with BDP or placebo. Data are presented for entry of study (open bars), after two weeks (hatched bars), four weeks (cross-hatched bars) and after six weeks (solid bars) of treatment. *: $p<0.02$ for BDP-treated patients versus placebo.

\section{DISCUSSION}

The present study demonstrates that erythrocyte levels of catalase increase and total glutathione levels decrease in patients with mild stable asthma, treated with beclomethasone dipropionate (BDP). Additionally, treatment with BDP resulted in a significant decrease in the total number of circulating eosinophils.

In asthma, numerous studies have shown that ROS are involved in the inflammatory process [1-7]. Alveolar macrophages of asthmatic patients demonstrated enhanced chemiluminescence, which correlated with asthma severity and bronchial hyperresponsiveness $[4,5]$. Not only in the pulmonary compartment an increased oxidative burden has been noted, also peripheral blood cells generate both spontaneously and after stimulation higher levels of ROS in comparison to healthy controls. This has been observed for both blood polymorphonuclear neutrophils and monocytes [1,2], and also for blood eosinophils [3].

Antioxidants levels increase in response to oxidant stress and can ameliorate oxidant induced injury [9]; knowledge of antioxidant defense levels is therefore essential to predict total outcome of tissue damage. In asthma, it has been shown that 
antioxidant levels are decreased, both in the pulmonary compartment $[23,26]$ as well as in peripheral blood [1,12]. RBC have been used to monitor long-term alterations in antioxidant status in chronic pulmonary disorders $[16,20]$, as well as in asthma [14].

In the present study, treatment with BDP resulted in an increase in RBC catalase activity, whereas no changes were observed in levels of GSH-Px, SOD and GST. RBC express high levels of catalase in contrast to, for instance, bronchial epithelial cells [9]. Catalase is one of the most important mechanisms by means of which $\mathrm{RBC}$ dispose of $\mathrm{H}_{2} \mathrm{O}_{2}$ [17] and $\mathrm{RBC}$ catalase has been demonstrated to protect cells from ROS-burden [17]. Therefore, the increase in RBC catalase in the present study reflects an increased defense against ROS-exposure. The observed negative correlation of baseline catalase levels with the response of catalase to BDP treatment, observed in the present study, leads to the assumption that RBC catalase levels may be a marker of the asthmatic inflammation, where lower levels of catalase reflect enhanced exposure to ROS. Indeed in asthmatic children, catalase levels have been shown to be decreased in comparison to controls [14].

Several mechanisms may be involved in the effect of BDP on RBC-catalase. Treatment with BDP attenuates the local inflammatory response as is shown in bronchial biopsies [27] and BAL [28]. This may lead to a reduction in the local formation of ROS. Recently, it was shown that monocytes of asthmatic patients, treated with inhaled steroids, produced less superoxide anions when stimulated with phorbol myristate-acetate (PMA) in comparison with monocytes of untreated asthmatic patients [29]. Furthermore, inhaled corticosteroids may decrease levels of inflammatory mediators, like TGF- $\beta$, which normally inhibit antioxidant gene activity [26], resulting in increased gene-transcription. Animal studies have shown that corticosteroids influence catalase gene-transcription. Dexamethasone has been shown in vitro to increase catalase-mRNA in perinatal rat lung cells [30] and to enhance SOD and GSH-Px enzyme activity in fetal rat lung [31]. Administration of corticosteroids in vivo increased catalase and GSH-Px activity in rat peritoneal macrophages and significantly inhibited in vitro hydrogen peroxide production in peritoneal macrophages [32]. Effects of corticosteroids on human cells are less clear. Although inhaled corticosteroids failed to influence ROS generation in stimulated alveolar macrophages [28], corticosteroids significantly reduced superoxide production in stimulated polymorphonuclear cells [33] and monocytes [29].

The present study observed a reduction in $\mathrm{RBC}$ total glutathione during treatment with BDP. Few data exist regarding glutathione levels in RBC of asthmatic patients [14]. Both animal and human studies have shown that glutathione levels can increase during oxidant stress. Increased levels of glutathione were demonstrated in BAL of asthmatic patients [10], in RBC of patients with chronic occupational lung disorders $[8]$ and in $\mathrm{RBC}$ of volunteers, participating in exercise train- 
ing [21]. The decrease in RBC glutathione, observed in the present study, may therefore reflect decreased oxygen radical exposure. Indeed, animal studies have observed that corticosteroids decrease oxidative metabolism, followed by a decrease in antioxidant enzyme levels [34]. Another explanation for the observed decrease of total glutathione in the present study may be that GSSG is transported out of the RBC; however, this mechanism mainly occurs in heart and liver cells [9] and is only observed in RBC, when exposed to very high levels of ROS. In addition, the observation of a decrease in RBC glutathione levels argues against systemic effects of inhaled BDP as an explanation for the observed changes in RBC antioxidant levels, since, in mice, systemically applied corticosteroids have been shown to increase hepatic synthesis of glutathione [35], which would raise levels of circulating glutathione.

The present study demonstrated that patients, responding to BDP with an increase in catalase, had higher eosinophil counts at entry than the patients not responding. In addition, the present study supports data from a previous study, which also demonstrated a reduction in peripheral blood eosinophils during treatment with inhaled corticosteroids [36]. Since the number of blood eosinophils have been shown to correlate with asthma-severity [37], the present study suggests that patient with higher levels of inflammation show lower levels of RBC catalase and higher blood eosinophil counts. The fact that the present study did not observe changes in asthma-severity, may be explained by the relative insensitivity of these parameters to monitor subtle inflammatory changes in patients with mild, stable asthma.

In conclusion, the present study demonstrates that, in patients with mild, stable asthma, treatment with inhaled beclomethasone dipropionate results in an increase in RBC catalase levels and, at the same time, a decrease in RBC glutathione. Peripheral blood eosinophil counts were higher in patients, who demonstrated an increase in RBC catalase during treatment with BDP. We speculate that inhaled BDP decreases ROS-generation within the lung, which leads to a subsequent change in systemic antioxidant levels. Further studies, simultaneously evaluating ROS formation within the lung while monitoring antioxidant defenses, will be needed in order to improve our understanding of the effects of inhaled corticosteroids on antioxidant defenses in asthma.

\section{ACKNOWLEDGEMENTS}

The authors wish to thank E. Rhijnsburger and A. Knaapen (Department of Health Risk Analysis and Toxicology) and L. Baars (Department of Pharmacology) for their assistance with the analyses. 


\section{REFERENCES}

1. Vachier I, Damon M, Doucen Le C, Crastes de Paulet A, Chanez P, Michel FB, Godard P. Increased oxygen species generation in blood monocytes of asthmatic patients. Am Rev Respir Dis 1992; 146: 1161-1166.

2. Vachier I, Chanez P, Doucen Le C, Damon, Descomps B, Godard P. Enhancement of reactive oxygen species formation in stable and unstable asthmatic patients. Eur Respir $/ 1994 ; 7$; 1585-1592.

3. Chanez P, Dent G, Yukawa T, Barnes PJ, Chung KF. Generation of oxygen free radicals from blood eosinophils from asthma patients after stimulation with PAF or phorbol esther. Eur Respir J 1990; 3: 1002-1007.

4. Cluzel M, Damon M, Chanez P, Bousquet J, Crastes de Paulet C, Michel FB, Godard P. Enhanced alveolar cell luminol-dependent chemiluminescence in asthma. I Allergy Clin Immunol 1987; 80: 195-201.

5. Kelly C, Ward C, Stenton CS, Bird G, Hendrick DJ, Walters EH. Number and activity of inflammatory cells in broncho-alveolar lavage fluid in asthma and their relation to airway responsiveness. Thorax 1988; 43: 684-692.

6. Sanders SP, Zweier JL, Harrison J, Trush MA, Rembish SJ, Liu MC. Spontaneous oxygen radical production at sites of antigen challenge in allergic subjects. Am J Respir Crit Care Med 1995; 151: 1725-1733.

7. Barnes PJ. Reactive oxygen species and airway inflammation. Free Radic Biol Med 1990; 9 : 235-243.

8. Borm PJA, Bast A, Wouters EFM, Slangen JJ, Swaen GMH, De Boorder TJ. Red blood cell antioxidant parameters in healthy elderly subjects versus silicosis patients. Free Rad Res Commun 1987; 3: 117-127.

9. Heffner JE, Repine JE. Pulmonary strategies of antioxidant defense. Am Rev Respir Dis 1989; 140: 531-554.

10. Smith $\amalg$, Houston M, Anderson J. Increased levels of glutathione in broncho-alveolar lavage fluid from patients with asthma. Am Rev Respir Dis 1993; 147: 1461-1464.

11. Durham SR, Carroll M, Walsh GM, Kay AB. Leucocyte activation in allergen-induced late-phase asthmatic reaction. N Eng/ J Med 1984; 311: 1398-1402.

12. Malmgren $\mathrm{R}$, Unge $\mathrm{G}$, Zetterstrom $\mathrm{O}$, Theovell $\mathrm{H}$, de Wahl $\mathrm{K}$. Lowered glutathione peroxidase activity in asthmatic patients with food and aspirin intolerance. Allergy 1986; 41: 43-45.

13. Stone J, Hinks U, Beasley R, Holgate ST, Clayton BE. Reduced selenium status of patients with asthma. Clin Sci 1989; 77: 495-500.

14. Novák Z, Németh I, Gyurkovits K, Varga Sz I, Matkovics B. Examination of the role of oxygen free radicals in bronchial asthma in childhood. Clin Chimica Acta 1991; 201: 247-252.

15. Rahman I, Morrison D, Donaldson K, MacNee W. Systemic oxidative stress in asthma, COPD and smokers. Am J Respir Crit Care Med 1996; 154: 1055-1060.

16. Schins RPF, Keman S, Borm PJA. Blood antioxidant status in coal dust-induced respiratory disorders: a longitudinal evaluation of multiple biomarkers. Biomarkers 1997; 2: 45-50.

17. Agar NS, Sadrsadeh SMH, Hallaway PE, Eaton JW. Erythrocyte catalase; a somatic oxidant defense? J Clin Invest 1986; 77: 319-321.

18. Van Asbeck BS, Hoidal J, Vercelotti GM, Swarts BA, Moldow CF, Jacob HS. Protection against lethal hyperoxia by tracheal insufflation of erythrocytes; role of red cell glutathione. Science 1985; 227: 756-759.

19. Andersen HR, Nielssen JB, Nielsen F, Grandjean Ph. Antioxidative enzyme activities in human erythrocytes. Clin Chemistry 1997; 43: 562-568.

20. Engelen JJM, Borm PJA, van Sprundel M, Leenaerts L. Blood anti-oxidant parameters at different stages of pneumoconiosis in coal workers. Env Health Persp 1990; 84: 165-172.

21. Evelo CTA, Palmen NGM, Artur Y, Janssen GME. Changes in blood glutathione concentrations, and in erythrocyte glutathione reductase and glutathione S-transferase 
activity after running training and after participation in contest. Eur J Appl Physiol 1992; 64: 354-358.

22. Barnes PJ. Anti-inflammatory therapy for asthma. Annu Rev Med 1993; 44: 229-242.

23. De Raeve HR, Thunissen FBJM, Kaneko FT, Guo FH, Lewis M, Kavuru MS, Secic M, Thomassen MJ, Erzurum SC. Decreased Cu,Zn-SOD activity in asthmatic airway epithelium: correction by inhaled corticosteroid in vivo. Am J Physiol 1997; 272: L148-L154.

24. Pennings HJ, Wouters EFM. Effect of inhaled beclomethasone dipropionate on isocapnic hyperventilation with cold air in asthmatics, measured with forced oscillation technique. Eur Respir J 1997; 10: 665-671.

25. van Kampen EJ, Zijlstra WG. Determination of hemoglobin and its derivatives. Adv Clin Chem 1965: 8; 141-187.

26. Smith U, Shamsuddin M, Sporn PH, Denenberg M, Anderson J. Reduced superoxide dismutase in lung cells of patients with asthma. Free Rad Biol Med 1997; 7: 1301-1307.

27. Djukanovic R, Wilson JW, Britten KM, Wilson SJ, Walls AF, Roche WR, Howarth PH, Holgate ST. Effect of an inhaled corticosteroid on airway inflammation and symptoms in asthma. Am Rev Respir Dis 1992; 145: 669-674.

28. Duddridge M, Ward C, Hendrick DJ, Walters EH.Changes in bronchoalveolar lavage inflammatory cells in asthmatic patients treated with high dose inhaled beclomethasone dipropionate. Eur Respir J 1993; 6: 489-497.

29. Majori M, Vachier I, Godard P, Farce M, Bousquet J, Chanez P. Superoxide anion production by monocytes of corticosteroid-treated asthmatic patients. Eur Respir J 1998; 11: 133-138.

30. Clerch LB, Iqbal J, Massaro D. Perinatal rat lung catalase gene expression: influence of corticosteroids and hyperoxia. Am J Physiol 1991; 260: L428-L433.

31. Frank L, Lewis PL, Sosenko IRS. Dexamethasone stimulation of fetal rat lung antioxidant enzyme activity in parallel with surfactant stimulation. Pediatrics 1985; 75: 569-574.

32. Pereira B, Costa Rosa LFBP, Safi SA, Bechara EJH, Curi R. Hormonal regulation of superoxide dismutase, catalase and glutathione peroxidase activities in rat macrophages. Biochem Pharmacol 1995; 50: 2093-2098.

33. Goldstein IM, Roos D, Weissman G, Kaplan HB. Influence of corticosteroids on human polymorphonuclear leucocyte function in vitro. Reduction of lysosomal enzyme release and superoxide production. Inflammation 1976; 1: 305-315.

34. Weglarz L, Drózdz M, Goss M. Effect of anti-inflammatory drugs on the activity of antioxidant anzymes and in vivo peroxidation products in the liver and kidney of rat. Comp Biochem Physiol 1990; 96C: 83-85.

35. Speck RF, Schranz C, Lauterburg BH. Prednisolone stimulates hepatic glutathione synthesis in mice. J Hepatol 1993; 18: 62-67.

36. Evans PM, O'Connor BJ, Fuller RW, Barnes PJ, Chung KF. Effect of inhaled corticosteroids on peripheral blood eosinophil counts and density profiles in asthma. I Allergy Clin Immunol 1993; 91: 643-650.

37. Bousquet J, Chanez P, Lacoste JY, Barnéon G, Ghavanian N, Enander I, Venge P, Ahlstad S, Simony-Lafontaine J, Godard Ph, Michel FB. Eosinophilic inflammation in asthma. N Engl J Med 1990; 323: 1033-1039. 


\section{CHAPTER 9}

\section{Summary and general discussion}

\subsection{SUMMARY OF THE OBSERVATIONS IN THE THESIS}

The first part of the thesis focuses on the effect of TNF $\alpha$ on bronchial hyperresponsiveness in vitro and evaluates possible immunomodulatory effects of drugs, used in the treatment of asthma, in in vitro models.

TNF $\alpha$ is implicated in the pathogenesis of asthma, as has been shown in several studies $[1,2,3,4]$. TNF $\alpha$ release is increased in cells, involved in the asthmatic inflammation e.g. mast cells [5], epithelial cells [6], activated T-lymphocytes [7] and macrophages [8] and enhanced levels of TNF $\alpha$ may in turn augment the inflammatory response [6,9]. Increased levels of TNF $\alpha$ have been observed in the the late asthmatic reaction (LAR) $[10,11,12]$, as well as after IgE-receptor crosslinking [13]. Since the LAR is associated with an increase in bronchial hyperresponsiveness, we speculated that TNF $\alpha$ itself may affect the contractile response of bronchial smooth muscle directly. In chapter 3, we investigated the effect of TNF $\alpha$ on the isotonic contraction of tracheal smooth muscle strips of unsensitized guineapigs in organ baths. Incubation of tracheal strips for $30 \mathrm{~min}$ with TNF $\alpha$ $\left(10^{-13}-10^{-10} \mathrm{M}\right)$, induced an increase in methacholine-induced maximum contraction by $70 \%$. The specificity of the observed effect was demonstrated by coincubating recombinant human TNF $\alpha$ with a soluble TNF-Receptor construct (sTNFR-p80-construct), which completely inhibited the increase in contractility. In contrast to the effects of TNF $\alpha$ on membrane potentials in striated muscle [14], we observed a very steep dose-response effect in tracheal smooth muscle, suggesting a differential effect of TNF $\alpha$ in the two muscle types. We also observed that the effect of TNF $\alpha$ was only apparent after a $30 \mathrm{~min}$ washing period, whereas no effect was observed on methacholine-induced contraction, when tracheal strips were stimulated directly after the incubation-period. Since this may suggest involvement of secondary mediators and, since TNF $\alpha$ induces activation of phospholipase $\mathrm{A}_{2}[8,15]$, we coincubated tracheal rings with indomethacin $\left(10^{-5}\right)$ (to block prostaglandin synthesis) and with a platelet activating factor antagonist (WEB $2086\left(10^{-6} \mathrm{M}\right)$ ), to inhibit PAF effects. We observed that, although indomethacin did induce changes in contractility itself, no effect was observed on $\mathrm{TNF} \alpha$-induced effects. In contrast, the PAF-antagonist completely inhibited TNF $\alpha$-induced hypercontractility, demonstrating the involvement of PAF. Considering the observed time-delay and the biological availability of PAF, we speculate that either TNF $\alpha$ induces PAF-synthesis within airway smooth muscle cells or 
that smooth muscle cells interact with cells, expressing PAF at their surface. The present study therefore extends observations from previous studies in humans $[16,17]$, demonstrating that TNF $\alpha$ can affect bronchial smooth muscle cells directly.

After the demonstration of a direct effect of TNF $\alpha$ on smooth muscle contractility, we analysed in chapter 4 the effects of theophylline on the release of proinflammatory mediators (TNF $\alpha, \mathrm{IL}-6, \mathrm{IL}-8)$ and soluble TNF-receptors in peripheral blood monocytes and alveolar macrophages. Theophylline induced a dose-dependent inhibition of TNF $\alpha$ release in lipopolysaccharide (LPS) stimulated monocytes in vitro; theophylline partially inhibited TNF $\alpha$ release at a concentration of 20 $\mu \mathrm{g} / \mathrm{ml}$, however maximum inhibition was observed at concentrations of $80 \mu \mathrm{g} / \mathrm{ml}$, well above clinically acceptable levels. Additional analysis showed that theophylline $(20 \mu \mathrm{g} / \mathrm{ml})$ induced a $59 \%$ inhibition of LPS-induced TNF $\alpha$ mRNA accumulation and also inhibited LPS-induced IL- 6 mRNA accumulation by $49 \%$. However, IL-6 was only mildly decreased on protein level, suggesting that posttranscriptional adaptive mechanisms exist, which compensate for the reduced IL-6 mRNA synthesis, induced by theophylline. We also showed hat the observed decrease in TNF $\alpha$ synthesis was not induced by enhanced levels of IL-10, in contrast to other studies $[18,19]$. Theophylline induced, parallel to a decrease in TNF, a decreased release of IL-10, probably secondary to a decreased TNF $\alpha$ release [20]. In line with observations with $\mathrm{PGE}_{2}$ [21], theophylline did not affect cytokine release in alveolar macrophages, probably due to differences in the level of maturation between alveolar macrophages and peripheral blood monocytes. This difference in maturation might also explain the observation that levels of LPS-induced TNF $\alpha$ release were much higher in alveolar macrophages than in monocytes. In addition, theophylline induced changes in the shedding of sTNFReceptor-75 in monocytes, whereas no effect was observed in alveolar macrophages. The importance of this effect is not clear yet.

In human endothelial cells, theophylline $(100 \mu \mathrm{g} / \mathrm{ml})$ inhibited the expression of VCAM-1 in TNF $\alpha$-stimulated cells, whereas no effect was observed on LPSstimulated cells. Theophylline did not affect cytokine (IL-6 and IL-8) release of endothelial cells, nor influence the expression of ICAM-1 and E-selectin on endothelial cells. Since the ligand of VCAM-1, VLA-4 (very late antigen-4) is expressed on eosinophils and T-lymphocytes, observations from our study provide a mechanism for the observed inhibition of T-lymphocyte and eosinophil influx in bronchial mucosa by theophylline [22]. This may also explain why withdrawal of theophyllline in patients with asthma resulted in an increase in T-lymphocytes, infiltrating the airways [23]. In conclusion, the present study shows that theophylline has immunomodulatory effects in vitro, which may explain part of the beneficial effects of theophylline in the treatment of asthma in vivo [24]. 
In accordance with observations on theophylline, addition of long-acting $\beta_{2}$-agonists to treatment regimens in asthma show an advantageous effect, which could involve immunomodulatory effects of $\beta_{2}$-agonists [25,26]. In chapter 5 effects of salmeterol and salbutamol were investigated on the release of proinflammatory cytokines (TNF $\alpha$, IL-6 and IL-8) in LPS-stimulated monocytes of healthy volunteers in vitro. Both salmeterol $\left(10^{-8}-10^{-6} \mathrm{M}\right)$ and salbutamol $\left(10^{-8}-10^{-4} \mathrm{M}\right)$ inhibited TNF $\alpha$ release (maximum inhibition $\pm 50 \%$ ), whereas a trend in inhibition of IL- 6 release was observed. The specificity of the observed response was shown by coincubation of salmeterol and salbutamol with propranolol, a non-selective $\beta$-antagonist, that completely reversed the inhibition of TNF $\alpha$ release. Additional analysis showed that, in contrast to theophylline, IL-10 may be involved in the observed immunomodulatory effects, since salmeterol and salbutamol induced enhanced IL-10 release in the presence of LPS $(1 \mu \mathrm{g} / \mathrm{ml})$. However, since TNF $\alpha$ release was also inhibited in experiments without IL-10 induction, effects of salmeterol and salbutamol on LPS-induced gene-transcription for TNF $\alpha$ and IL- 6 were analysed. Both drugs inhibited TNF $\alpha$ mRNA accumulation and to a minor extent IL-6 mRNA. Comparison of the inhibitory effects of salmeterol and salbutamol on TNF $\alpha$ release demonstrated that salbutamol dose-dependently inhibited TNF $\alpha$ release, whereas salmeterol appeared to reach already maximum inhibition at much lower concentrations.

The second part of the thesis evaluates the effect of inhaled beclomethasone dipropionate in patients with mild, stable asthma with regard to asthma-symptoms and bronchial hyperresponsiveness, as assessed with cold air bronchoprovocation. In addition, the effect of beclomethasone on biomarkers in peripheral blood of asthmatic patients was evaluated.

In chapter 6, we evaluated the effect of treatment with inhaled beclomethasone dipropionate $\left(1000 \mu \mathrm{g}\right.$.day ${ }^{-1}$ for six weeks) on asthma symptoms, peak-flow, pulmonary function and bronchial hyperresponsiveness. Forty (steroid-naive) patients with mild, stable asthma were included in a double-blind, placebo-controlled parallel-group study. Stratification according to sex was performed to overcome differences in airway diameter. Bronchial hyperresponsiveness was assessed by an indirect bronchial challenge test, i.e. isocapnic hyperventilation with cold air (IHCA). We chose to study the effects of an indirect bronchial challenge test with IHCA, since IHCA provides a more physiological stimulus for airway contraction and represents a highly specific test for increased airway hyperreactivity [27]. The response to IHCA was analysed using both conventional flow-volume recordings by a pneumotachograph as with the forced oscillation technique (FOT). This method requires no deep inspiratory manoeuvre, which may influence bronchial tone and may influence the result of bronchoprovocation testing [28]. We ob- 
served that IHCA induced a significant decrease in FEV, from baseline $(18 \%$ pred.) and that characteristic changes occurred in the FOT recordings, i.e. an increase in resistance at $8 \mathrm{~Hz}(R 8)$ and the development of a negative frequency dependence (FD) curve. Changes in reactance resulted in an increase in resonant frequency $\left(f_{0}\right)$ and a decrease in reactance at $8 \mathrm{~Hz}(X 8)$. These results were in line with previous data [29,30]. Also, responses in FOT parameters correlated with changes in $\mathrm{FEV}_{\text {, }}$ (correlation with change in $R 8: \mathrm{r}=-0.68, \mathrm{p}<0.001$; with FD: $\mathrm{r}=0.67, \mathrm{p}<0.001$; with $X 8: \mathrm{r}=0.65, \mathrm{p}<0.001$ and with $f_{0}: \mathrm{r}=-0.67, \mathrm{p}<0.001$ ); the present data confirm observations from previous studies [30]. Treatment with beclomethasone dipropionate (BDP) induced statistically significant changes in effects of IHCA, as assessed with the FOT. BDP treatment resulted in: a diminished increase in $R 8$ induced by IHCA; a decrease in the steepness of the slope of the FD-curve; a decrease in $X 8$ changes after IHCA and a decrease in change of $f_{0}$, following IHCA. Although a trend towards a decreased change in FEV after IHCA was observed, these results did not reach statistical significance. In addition, a high correlation was observed between IgE levels in patients and the effect of BDP on IHCA, as assessed by FOT $(r=0.88, p<0.001)$. These observations are in accordance with data from a previous study [31]. No changes were observed in asthmasymptom scores, peak flow rates and use of $\beta_{2}$-agonists. However, it should be noticed that all patients in the study group had very mild asthma. In summary, this study showed that beclomethasone reduces bronchial hyperresponsiveness in stable asthmatic patients and the study demonstrated that the forced oscillation technique was more sensitive to changes in bronchial tone than conventional flowvolume recordings.

In chapter 7, we studied levels of inflammatory mediators in peripheral blood of the asthmatic patients, participating in the study, as described in chapter five. We chose to study levels of soluble adhesion molecules, because expression of adhesion molecules is increased in the bronchial mucosa in asthmatic patients [32,33] and increased levels of sICAM-1 and sE-Selectin have been observed in blood of patients with acute asthma [34,35]. Also, after segmental allergen challenge, increased levels of sICAM-1 have been found in blood [36], suggesting that soluble adhesion molecule levels in the circulation may reflect inflammatory changes within the pulmonary compartment. Since TNF $\alpha$ is very potent in the upregulation of adhesion molecule expression on endothelial and epithelial cells $[6,8]$, we also measured levels of soluble TNF-receptors, since they reflect the inflammatory status of patients [37]; in addition, one study has observed increased levels of soluble TNF-receptors in acute asthma [38]. At entry of the study, levels of sICAM-1, sE-Selectin-1, sTNF-R55 and sTNF-R75 in our group of asthmatic patients were comparable with levels in a group of healthy volunteers (age 20-40 yrs). These observations are in line with previous observations $[34,35]$. Treatment with BDP re- 
sulted in a significant, although small decrease in sTNF-R55, already apparent from 2 weeks of treatment. Furthermore, BDP induced a gradual decrease in sICAM-1 levels, which reached significance after 6 weeks of treatment. Interestingly, the magnitude of BDP-induced decrease in sICAM-1 $(30 \mathrm{ng} / \mathrm{ml})$ was comparable to the changes in sICAM-1, observed in peripheral blood after segmental allergen challenge [36]. In addition, we also observed that BDP induced a decrease in blood eosinophils, which was already apparent after two weeks treatment with BDP (in analogy with the trend observed in sTNF-R55). No changes occurred in levels of sTNF-R75 and sE-Selectin-1. Although effects of BDP on levels of sTNF-R55 and sICAM-1 were significantly correlated with the initial levels of these markers at entry of the study, no correlations could be demonstrated between the effect of BDP on levels of inflammatory mediators and indicators of asthma-severity (pulmonary function, bronchial hyperresponsiveness and number of blood eosinophils). We suggest that the observed changes in sTNF-R55 and sICAM-1 reflect the anti-inflammatory effects of beclomethasone on bronchial inflammation.

In chapter 8, we analysed the levels of antioxidant enzymes (superoxide dismutase, catalase, glutathione peroxidase, glutathione $\mathrm{S}$-transferase) and total cell glutathione in erythrocytes of patients, participating in the study, as described in chapter five. Besides enhanced production of cytokines, cells involved in the asthmatic inflammation also produce increased amounts of reactive oxygen species (ROS) $[39,40,41]$. ROS are involved in the pathogenesis of asthma, since they induce changes in airway contractility, induce plasma leakage and induce release of secondary mediators e.g. PAF [42]. Besides increased ROS exposure, antioxidant defenses in asthma are decreased, resulting in a further disturbed oxidantantioxidant balance [43]. Several studies demonstrated decreased levels of glutathione peroxidase $[44,45]$ and catalase [46] in asthmatic patients. In this study, we analysed the effect of inhaled beclomethasone on antioxidant levels in erythrocytes, since several studies have shown that erythrocyte antioxidant levels reflect chronic changes in exposure to ROS $[47,48,49,50]$. In this study, we showed that treatment with BDP induced a gradual increase in erythrocyte catalase levels, which reached significance after 6 weeks. In contrast, treatment with BDP resulted in a gradual decrease in the total content of erythrocyte glutathione, which became significant after 6 weeks. We also showed that BDP-induced change in catalase levels inversely correlated with catalase levels at entry, suggesting that patients with lower catalase levels represented patients with more serious asthma. Futhermore, it was shown that patients, who responded to corticosteroid treatment by a rise in catalase levels, had higher blood eosinophil counts than patients, who did not respond to beclomethasone with a rise in catalase levels. For effects of $\mathrm{BDP}$ on glutathione levels, this distinction was not observed. Also, within the 
present study, we could observe no correlations between erythrocyte antioxidant enzyme levels and indicators of asthma severity (pulmonary function, bronchial hyperresponsiveness, IgE), nor did effects of BDP on antioxidant levels correlate with asthma severity.

We speculate that the observed changes in antioxidant levels in erythrocytes reflect a decreased exposure to ROS, induced by anti-inflammatory effects of BDP within the airways.

\subsection{GENERAL DISCUSSION}

In this thesis, it was demonstrated that TNF $\alpha$ induces BHR by a direct effect on airway smooth muscle; however, although other cytokines, like IL-5 and IL-4, are also implicated in the development of BHR, it is not clear yet whether they induce BHR directly or indirectly [51]. Since TNF $\alpha$ is produced early in the inflammatory response and has been shown to induce cytokine release in cells and enhance adhesion molecule expression [6], TNF $\alpha$ can be considered to play a central role in the asthmatic inflammation [52]. We therefore investigated possibilities for pharmacological immunomodulation of TNF $\alpha$ by drugs, used in the treatment of asthma. The inhibitory effects of salbutamol and salmeterol on gene-transcription for TNF $\alpha$ and IL- 6 were shown to be comparable with the effects of theophylline; however, for salbutamol and salmeterol, effects were achieved at concentrations, which resemble local concentrations within the airways, whereas for theophylline effects were achieved at relatively high concentrations. The in vitro studies were performed in cells, obtained from healthy subjects and may not accurately reflect the activation status of inflammatory cells, observed in asthmatic patients. In case of theophylline, studies have shown that theophylline has an increased inhibitory effect on phosphodiesterase in atopic patients in comparison with healthy subjects [53], suggesting that theophylline may achieve immunomodulatory effects in asthma at even lower concentrations. This observation is supported by observations from clinical studies [22,23]. Specific type IV phosphodiesterase-inhibitors, which are currently under development, have been shown in vitro to possess immunomodulatory effects at much lower concentrations than theophylline [54] and may represent potent drugs in asthma treatment.

Although we observed immunomodulatory effects for the $\beta_{2}$-agonists in pharmaceutical concentrations, studies in humans have shown differences between the protective effects of long-acting $\beta_{2}$-agonists in acute inflammatory reactions, as observed after allergen challenge [55,56,57] and effects, observed in chronic asthma [58,59]. After allergen challenge, salmeterol decreased levels of IL-4,-5 and ECP [55] and inhibited the development of bronchial hyperresponsiveness [56]. The observed protection of salmeterol on the development of BHR may, at least in 
part, be explained by the inhibitory effect of salmeterol on TNF $\alpha$ release, as observed above (chapter 3 and 5). The discrepancy, observed between effects of salmeterol in in vitro studies and effects on bronchial inflammation in vivo, especially in chronic asthma, is difficult to explain. For salbutamol, the absence of an effect in vivo can be explained by its short duration of action, but salmeterol may induce immunomodulatory effects in vivo, due to its longer duration of action. It is possible that in chronic asthma, $\beta$-receptor activation may result in a decreased cAMP generation, due to the inflammation. This hypothesis is supported by the observation that activated alveolar macrophages of asthmatic patients generate less cAMP than macrophages, obtained from healthy volunteers [60]. In contrast, the bronchodilating capacities of salmeterol are preserved, since bronchodilation by $\beta$-agonists is reported to occur mainly through maxi-K channels, opened directly by a subunit of the stimulatory G-protein, suggesting that smooth muscle relaxation may occur, independent of an increase in cAMP [61]. Since cAMP is an important secondary mediator in the immunomodulatory effects of $\beta$-receptor agonists $[62,63]$, this may explain why effects of $\beta_{2}$-agonists are less obvious in asthmatic inflammation in vivo. Therefore, the addition of corticosteroids to treatment with long-acting $\beta_{2}$-agonists may result in enhanced anti-inflammatory effects of $\beta$-agonists and may result in an improved control of asthma $[25,26]$.

In the second part of the thesis, we evaluated the effect of corticosteroids on airway hyperresponsiveness in asthmatic patients and we simultaneously monitored changes in peripheral blood markers.

The study was performed in patients with stable, mild asthma, who, according to the new guidelines for classification of asthma [64], should be classified in the group of intermittent asthma, as judged by their $\mathrm{FEV}_{1}$, asthma-symptom score (mild dyspnea once a day) and peak flow variability $(<10 \%)$. Several studies have observed that, even in this group of patients with mild stable asthma, increased numbers of mast cells, eosinophils, lymphocytes and macrophages are present within the bronchial mucosa and epithelium $[65,66]$. In addition, an increased thicknesss of the basement membrane was observed in these patients [66], suggesting that airway remodelling represents an early event in the pathophysiology of asthma.

Our patient group demonstrated a considerable bronchial hyperresponsiveness, as was shown by the response to IHCA, which was substantially increased in comparison to healthy subjects $[27,67]$. Treatment with beclomethasone resulted in the reduction of BHR as assessed with FOT. The absence of an effect, as assessed by $\mathrm{FEV}_{1}$ measurement, can be explained by a recent study, demonstrating that, especially in patients with the mildest form of airway obstruction, the performance of a deep inspiratory manoeuvre, as is required for the measurement of $\mathrm{FEV}_{1}$, resulted in the largest reversal of bronchial obstruction [68]. 
The general concept, that BHR and airway inflammation are correlated [69], suggests that airway inflammation is present in our patients. Although we did not perform bronchial biopsies in our patients to assess changes in bronchial inflammation, beclomethasone dipropionate, used in an almost similar treatment protocol, induced a significant reduction in the number of epithelial and mucosal mast cells, eosinophils and T-lymphocytes [70]. Also, a significant reduction in Tlymphocyte activation markers was observed, both in BAL and to a lesser extent in peripheral blood [71]. In these studies, patient groups were comparable with regard to baseline pulmonary function to our patient group, although PEF variability, asthma symptom score and bronchial hyperreactivity were somewhat higher. In the last two chapters of this thesis, we monitored changes in peripheral blood markers, which might reflect changes in bronchial inflammation. Since pilot studies showed that proinflammatory cytokines (TNF $\alpha$, IL- 6 and IL-8) could not be detected in peripheral blood of our patients, other markers, involved also in the asthmatic inflammation, were used. The present study observed that, parallel to the observed decrease in BHR, levels of circulating TNF-R55 and ICAM-1 decreased, as did the number of peripheral blood eosinophils. BDP may decrease levels of circulating mediators either by inhibiting synthesis in epithelial [72] or endothelial cells [73], or indirectly, by inhibiting the release of cytokines, that can regulate the expression of these molecules, like e.g. TNF $\alpha$ or IL-4.

The effect of BDP on the number of circulating eosinophils are in line with data from previous studies [74]. Studies suggest that colony-stimulating factors released from cells, within the pulmonary compartment, may influence hematopoetic cells. Whether the observed decrease in number of eosinophils is the result of reduced production of these colony-stimulating factors (e.g. IL-5) within the lung $[12,75]$, or that corticosteroids have a direct effect on bone marrow by preventing the release of maturing eosinophils into the blood stream, is not clear. We speculate that the reduction in peripheral blood eosinophils probably reflects reduced airway inflammation with subsequent decrease in eosinophil colony forming units.

The observed changes in erythrocyte antioxidant levels may be induced by a decreased generation of ROS, induced by effects of BDP on asthmatic inflammation. The changes in erythrocyte antioxidant levels may reflect the adjustment of antioxidant levels in erythrocyte progenitor cells, which respond to a decreased exposure to ROS in the circulation. In asthmatic patients, ROS generation is increased $[76,77]$ and, even in patients with stable asthma, the oxidant-antioxidant balance is disturbed, as was demonstrated in peripheral blood [78]. In order to treat our patients most efficiently, we need to know whether primary therapy in asthma should be aimed at controlling ROS production or providing additional antioxidative defenses. Future studies in asthmatic patients should analyse the oxi- 
dative burden and antioxidant defenses simultaneously in order to answer this question.

Studies in the second part of the thesis showed that treatment with BDP induced changes in BHR and levels of inflammatory mediators, whereas judging from their clinical status, patients were considered not to be candidates for treatment with inhaled steroids. However, it has been shown that a dissociation may occur between asthma symptoms and levels of airway inflammation in stable asthmatics [79]. The former study also showed that airway inflammation and BHR correlated quite well. This might imply that levels of BHR (as indirect indicators of airway inflammation and airway remodelling) should be added to the current guidelines for the treatment of asthma, in addition to evaluation of asthma symptoms. This has recently been suggested by Sont $e t$ al., who showed that this policy leads to an improved control of asthma and, more-over, results in a decrease in the thickness of the basement membrane [80]. One study also showed that early introduction of inhaled corticosteroids may reverse airway collagen deposition [81], which may occur due to actions of inflammatory mediators (like IL-4, TNF $\alpha$ ) [82]. This implies that sensitive methods, that can detect even mild inflammatory changes, are needed in order to prevent chronic airway remodelling.

From our studies, it can be concluded, that the markers, used in this thesis for the monitoring of asthmatic disease, did not live up to the criteria for "biomarkers"; levels of peripheral blood sICAM-1 and sTNF-R55 did not discriminate between asthmatics and healthy subjects, whereas sICAM-1, sTNFR-55 and antioxidant levels in erythrocytes did not correlate with levels of asthma severity nor did they correlate with BDP-induced changes in BHR. The absence of a clear correlation between the circulating inflammatory mediators and asthmatic inflammation is probably explained by the fact that asthma is primarily an inflammation within the pulmonary compartment and, although leakage of inflammatory mediators and activated cells occurs into the general circulation, these inflammatory mediators in peripheral blood insufficiently reflect the intensity of asthmatic inflammation. Therefore these markers can not be used as single markers in peripheral blood, reflecting disease in individual patients with asthma. Determination of the inflammatory markers, used in this thesis, in combination with newer techniques (i.e. induced sputum) may provide a solution. Also combining newly developed techniques may increase their potential usefulness in the monitoring of asthmatic inflammation; a recent study showed, that the combination of NO measurements in exhaled air and the number of eosinophils in induced sputum extend the estimation of airway inflammation, although correlation with asthma symptoms was low [83]. In addition, certain markers may not be useful in patients, treated with corticosteroids [84], since corticosteroids may have a direct inhibiting effect on the marker itself, instead of reflecting asthmatic inflammation [85]. Whether the 
combination of peripheral blood markers (e.g. ECP, circulating adhesion molecules, T-lymphocyte-activation markers) and the newer techniques will be more valuable in the assessment and the monitoring of asthmatic inflammation in the individual patient needs further investigation.

\section{REFERENCES}

1. Ying S, Robinson DS, Varney V, Meng Q, Tsicopoulos A, Moqbel R, Durham SR, Kay AB, Hamid Q. TNF $\alpha$ mRNA expression in allergic inflammation. Clin Exp Allergy 1991, 21: 745-750.

2. Ackerman V, Marini M, Vittori E, Bellini A, Vassali G, Mattoli S. Detection of cytokines and their cell sources in bronchial biopy specimens from asthmatic patients. Relationship to atopic status, symptoms, and level of airway hyperresponsiveness. Chest 1994; 105: 687-696.

3. Broide DH, Lotz M, Cuomo AJ, Coburn DA, Federman EC, Wasserman SI. Cytokines in symptomatic asthma airways. J Allergy Clin Immunol 1992; 89: 958-967.

4. Naseer T, Minshall EM, Leung DYM, Laberge S, Ernst P, Martin RJ, Hamid Q. Expression of IL-12 and IL-13 mRNA in asthma and their modulation to steroid therapy. Am J Respir Crit Care Med 1997; 155: 845-851.

5. Bradding P, Holgate ST. The mast cell as a source of cytokines in asthma. Ann N Y Acad Sci USA 1996; 796: 272-281.

6. Shelhaemer JH, Levine SJ, Wu T, Jacoby DB, Kaliner MA, Rennard SI. Airway Inflammation. Ann Intern Med 1995; 123: 288-304.

7. Steffen M, Ottmann OG, Moore MAS. Simultaneous production of tumor necrosis factor- $\alpha$ and lymphotoxin by normal T cells after induction with IL-2 and anti-T3. J Immunol 1988; 140: $2621-2624$.

8. Beutler B, Cerami A. The biology of cachectin/TNF-a primary mediator of the host response. Ann Rev Immunol 1989; 7: 625-655.

9. Bachwich PR, Chensue SW, Larrick LW, Kunkel SL. TNF stimulates interleukin-1 and prostaglandin $E_{2}$ production in resting macrophages. Biochem Biophys Res Commun 1986; 136: 94-101.

10. Gosset Ph, Tsicopoulos A, Wallaert B, Vannimenus C, Joseph M, Tonnel A-B, Capron A. Increased secretion of tumor necrosis factor $\alpha$ and interleukin- 6 by alveolar macrophages consecutive to the development of the late asthmatic reaction. J Allergy Clin Immunol 1991; 88: 561-571.

11. Keatings VM, O'Connor BJ, Wright LG, Huston DP, Corrigan CJ, Barnes PJ. Late response to allergen is associated with increased concentrations of tumor necrosis factor- $\alpha$ and IL- 5 in induced sputum. J Allergy Clin Immunol 1997; 99: 693-698.

12. Ohkawara Y, Lei X-F, Stämpfli MR, Marshall JS, Xing Z, Jordana M. Cytokine and eosinophil responses in the lung, peripheral blood and bone marrow compartments in a murine model of allergen-induced airways inflammation. Am J Respir Cell Mol Biol 1997; 16: 510-520.

13. Gosset P, Tsicopoulos A, Wallaert B, Joseph M, Capron A, Tonnel AB. Tumor necrosis factor alpha and interleukin- 6 production by human mononuclear phagocytes from allergic asthmatics after IgE-dependent stimulation. Am Rev Respir Dis 1992; 146: 768-774.

14. Tracey KJ, Lowry SF, Beutler B, Cerami A, Albert JD, Shires GT. Cachectin/tumor necrosis factor mediates changes of skeletal muscle plasma membrane potential. J Exp Med 1986; 164: 1368-1373.

15. Bauldry SE, Mccall CE, Cousart SL, Bass DA. Tumor necrosis factor- $\alpha$ priming of Phospholipase $A_{2}$ activation in human neutrophils. An alternative mechanism of priming. $J$ Immunol 1991; 146: 1277-1285. 
16. Michel O, Ginanni R, Le Bon B, Content J, Duchateau J, Sergysels R. Inflammatory response to acute inhalation of endotoxin in asthmatic patients. Am Rev Respir Dis 1992; 146: 352-357.

17. Thomas WS, Yates DH, Barnes PJ. Tumor necrosis factor- $\alpha$ increases airway responsiveness and sputum neutrophilia in normal human subjects. Am J Respir Crit Care Med 1995; 152 : 76-80.

18. Strassmann G, Patil-Koota V, Finkelman F, Fong M, Kambayashi T. Evidence for the involvement of Interleukin 10 in the differential deactivation of murine peritoneal macrophages by prostaglandin $\mathrm{E}_{2}$. J Exp Med 1994; 180: 2365-2370.

19. Kambayashi T, Jacob CO, Zhou D, Mazurek N, Fong M, Strassmann G. Cyclic nucleotide phosphodiesterase type IV participates in the regulation of IL-10 and in the subsequent inhibition of TNF- $\alpha$ and IL- 6 release by endotoxin-stimulated macrophages. J Immunol 1995; 155: 4909-4916.

20. Platzer C, Meisel Ch, Vogt K, Platzer M, Volk H-D. Upregulation of monocytic IL-10 by tumor necrosis factor- $\alpha$ and CAMP elevating drugs. Inter Immunol 1995; 7: 517-523.

21. Strieter RM, Remick DG, Lynch JP, Genord M, Raiford C, Spengler R, Kunkel SL. Differential regulation of Tumor Necrosis Factor- $\alpha$ in human alveolar macrophages and peripheral blood monocytes: a cellular and molecular analysis. Am J Respir Cell Mol Biol 1989; 1: 57-63.

22. Sullivan P, Bekir S, Jaffar Z, Page C, Jeffery P, Costello J. Anti-inflammatory effects of low-dose oral theophylline in atopic asthma. Lancet 1994; 343: 1006-1008.

23. Kidney J, Domingez M, Taylor PM, Rose M, Chung KF, Barnes PJ. Immunomodulation by theophylline in asthma. Am J Respir Crit Care Med 1995; 151: 1907-1914.

24. Evans DJ, Taylor DA, Zetterstrom O, Chung F, O'Connor BJ, Barnes PJ. A comparison of low-dose inhaled budenoside plus theophylline and high-dose inhaled budenoside for moderate asthma. N Engl J Med 1997; 337: 1412-1418.

25. Greening AP, Ind PW, Northfield M, Shaw G. Added salmeterol versus higher-dose corticosteroids in asthma patients with symptoms on existing inhaled corticosteroid. Lancet 1994; 344: 219-224.

26. Woolcock A, Lundbeck B, Ringdal N, Jacques LA. Comparison of addition of salmeterol to inhaled steroids with doubling of the dose of inhaled steroids. Am J Respir Crit Care Med 1996; 153: 1481-1488.

27. Deal EC, McFadden ER, Ingram RH, Breslin FJ, Jaeger JJ. Airway responsiveness to cold air and hyperpnea in normal subjects and in those with hay fever and asthma. Am Rev Respir Dis 1980; 121: 621-628.

28. Orehek J, Nicoli MM, Delpierre S, Beaupre A. Influence of the previous deep inspiration on the spirometric measurement of provoked bronchoconstriction in asthma. Am Rev Respir Dis 1981; 123: 269-272.

29. Decramer M, Demedts M, Van de Woestijne KP. Isocapnic hyperventilation with cold air in healthy non-smokers, smokers and asthmatic subjects. Bull Eur Physiopathol Respir 1984; 20: 237-243.

30. Wesseling GJ, Vanderhoven-Augustin IMJ, Wouters EFM. Forced oscillation technique and spirometry in cold air provocation tests. Thorax 1993; 48: 254-259.

31. Kerstjens HAM, Schouten JP, Brand PLP, Schoonbrood DFME, Sterk PJ, Postma DS and the dutch CNSLD Study Group. Importance of total serum IgE for improvement in airways hyperresponsiveness with inhaled corticosteroids in asthma and chronic obstructive pulmonary disease. Am J Respir Crit Care Med 1995; 151: 360-368.

32. Vignola AM, Campbell AM, Chanez P, Bousquet J, Lacoste P, Michel F, Goddard P. HLA-DR and ICAM-1 expression on bronchial epithelial cells in asthma and chronic bronchitis. Am Rev Respir Dis 1993; 148: 689-694.

33. Gosset Ph, Tillie-Leblond I, Janin A, Marquette C-H, Copin M-C, Wallaert B, Tonnel A-B. Expression of E-selectin, ICAM-1 and VCAM-1 on bronchial biopsies from allergic and non-allergic asthmatic patients. Int Arch Allergy Immunol 1995; 106: 69-77. 
34. Montefort S, Lai CKW, Kapai P, Leung J, Lai KN, Chan HS, Haskard DO, Howarth PH, Holgate ST. Circulating adhesion molecules in asthma. Am J Respir Crit Care Med 1994; 149: 1149-1152.

35. Kobayashi T, Hashimoto S, Imai K, Amemiya E, Yamaguchi M, Yachi A, Horie T. Elevation of serum soluble intercellular adhesion molecule-1 (sICAM-1) and sE-selectin levels in bronchial asthma. Clin Exp Immunol 1994; 96: 110-115.

36. Takahashi N, Liu MC, Proud D, Yu XY, Hasegawa S, Spannhake EW. Soluble intercellular adhesion molecule 1 in bronchoalveolar lavage fluid of allergic subjects following segmental antigen challenge. Am J Respir Crit Care Med 1994; 150: 704-709.

37. Van Zee KJ, Kohno T, Fischer E, Rock CS, Moldawer LL, Lowry SF. Tumor necrosis factor soluble receptors circulate during experimental and clinical inflammation and can protect against excessive tumor necrosis factor $\alpha$ in vitro and in vivo. Proc Natl Acad Sci 1992; 89: 4845-4849.

38. Yoshida S, Hashimoto S, Nakayama T, Kobayashi T, Koizumi A, Horie T. Elevation of serum soluble tumour necrosis factor (TNF) receptor and IL-1 receptor antagonist levels in bronchial asthma. Clin Exp Immunol 1996; 106: 73-78.

39. Cluzel M, Damon M, Chanez P, Bousquet J, Crastes de Paulet C, Michel FB, Godard Ph. Enhanced alveolar cell luminol-dependent chemiluminescence in asthma. I Allergy Clin Immunol 1987; 80: 195-201.

40. Chanez P, Dent G, Yukawa T, Barnes PJ, Chung KF. Generation of oxygen free radicals from blood eosinophils from asthma patients after stimulation with PAF or phorbol esther. Eur Respir J 1990; 3: 1002-1007.

41. Vachier I, Damon M, Doucen Le C, Crastes de Paulet A, Chanez P, Michel FB, Godard Ph. Increased oxygen species generation in blood monocytes of asthmatic patients. Am Rev Respir Dis 1992; 146: 1161-1166.

42. Barnes PJ. Reactive oxygen species and airway inflammation. Free Radic Biol Med 1990; 9: 235-243.

43. Rahman I, Morrison D, Donaldson K, MacNee W. Systemic oxidative stress in asthma, COPD and smokers. Am J Respir Crit Care Med 1996; 154: 1055-1060.

44. Malmgren $\mathrm{R}$, Unge $\mathrm{G}$, Zetterstrom $\mathrm{O}$, Theovell $\mathrm{H}$, de Wahl $\mathrm{K}$. Lowered glutathione peroxidase activity in asthmatic patients with food and aspirin intolerance. Allergy 1986; 41: 43-45.

45. Stone J, Hinks U, Beasley R, Holgate ST, Clayton BE. Selenium status of patients with asthma. Clin Sci 1989; 77: 495-500.

46. Novák Z, Németh I, Gyurkovits K, Varga Sz I, Matkovics B. Examination of the role of oxygen free radicals in bronchial asthma in childhood. Clin Chimica Acta 1991; 201: 247-252.

47. Borm PJA, Bast A, Wouters EFM, Slangen JJ, Swaen GMH, De Boorder TJ. Red blood cell antioxidant parameters in healthy elderly subjects versus silicosis patients. Free Rad Res Commun 1987; 3: 117-127.

48. Schins RPF, Keman S, Borm PJA. Blood antioxidant status in coal dust-induced respiratory disorders: a longitudinal evaluation of multiple biomarkers. Biomarkers 1997; 2: 45-50.

49. Engelen JJM, Borm PJA, van Sprundel M, Leenaerts L. Blood anti-oxidant parameters at different stages of pneumoconiosis in coal workers. Env Health Persp 1990; 84: 165-172.

50. Evelo CTA, Palmen NGM, Artur Y, Janssen GME. Changes in blood glutathione concentrations, and in erythrocyte glutathione reductase and glutathione S-transferase activity after running training and after participation in contest. Eur J Appl Physiol 1992; 64: 354-358.

51. Pouwels RA, Bruselle GJ, Kips JC. Cytokine manipulation in animal models of asthma. Am J Respir Crit Care Med 1997; 156 (suppl 4): S78-S81.

52. Renzetti LM, Paciorek PM, Tannu SA, Rinaldi NC, Tocker JE, Wasserman MA, Gater PR. Pharmacological evidence for tumor necrosis factor as a mediator of allergic inflammation in the airways. J Pharmacol Exp Ther 1996; 278: 847-853. 
53. Chan SC, Hanifin JM. Differential inhibitor effects on cyclic adenosine monophosphate-phosphodiesterase isoforms in atopic and normal leucocytes. J Lab Clin Med 1993; 121: 44-51.

54. Semmler J, Wachtel H, Endres S. The specific type IV phosphodiesterase inhibitor rolipram suppresses tumor necrosis factor- $\alpha$ production by human mononuclear cells. Int J Immunopharmac 1993; 15: 409-413.

55. Murray JJ, Hagaman DD, Dworski R, Keane B, Sheller JR. Inhibition by salmeterol and beclomethasone of late phase response to segmental antigen challenge in asthmatics. Am J Respir Crit Care Med 1998; 157: A872.

56. Twentyman OP, Finnerty JP, Harris A, Palmer J, Holgate ST. Protection against allergen-induced asthma by salmeterol. Lancet 1990; 336: 1338-1342.

57. Pedersen B, Dahl R, Larsen BB, Venge $P$. The effect of salmeterol on the early-and late-phase reaction to bronchial allergen and postchallenge variation in bronchial reactivity, blood eosinophils, serum eosinophil cationic protein, and serum eosinophil protein X. Allergy 1993; 48: 377-382.

58. Roberts JA, Bradding P, Walls AF, Britten KM, Wilson S, Holgate ST, Howarth PH. The influence of salmeterol xinafoate on mucosal inflammation in asthma. Am Rev Respir Dis 1992; 145; A418.

59. Gardiner PV, Ward C, Booth H, Allison A, Hendrick DJ, Walters EH. Effect of eight weeks of treatment with salmeterol on bronchoalveolar lavage inflammatory indices in asthmatics. Am J Respir Crit Care Med 1994; 150: 1006-1011.

60. Bachelet M, Vincent D, Havet N, Marrash-Chahla R, Pradalier A, Dry J, Vargaftig BB. Reduced responsiveness of adenylate cyclase in alveolar macrophages from patients with asthma. $J$ Allergy Clin Immunol 1991; 88: 322-328.

61. Barnes PJ. Effect of beta-agonists on airway effector cells. In: Pouwels R, O'Byrne (eds). Beta ${ }_{2}$-agonists in asthma treatment. New York, Dekker 1997: pp 35-66.

62. Meisel C, Vogt K, Platzer C, Randow F, Liebenthal C, Volk H-D. Differential regulation of monocytic tumor necrosis factor- $\alpha$ and interleukin-10 expression. Eur J Immunol 1996; 26: 1580-1586.

63. Platzer C, Meisel Ch, Vogt K, Platzer M, Volk H-D. Upregulation of monocytic IL-10 by tumor necrosis factor- $\alpha$ and CAMP elevating drugs. Inter Immunol 1995; 7: 517-523.

64. WHO/NHLBI Workshop Report. Global stategy for asthma management and prevention. National Institutes of Health, National Heart, Lung and Blood Institute, Bethesda, MD. 1995; Publication No. 95-3659.

65. Laitinen LA, Laitinen A, Haahtela T. Airway mucosal inflammation even in patients with newly diagnosed asthma. Am Rev Respir Dis 1993; 147: 697-704.

66. Vignola AM, Chanez P, Campbell AM, Souques F, Lebel B, Enander I, Bousquet J. Airway inflammation in mild intermittent and persistent asthma. Am J Respir Crit Care Med 1998; 157: 403-409.

67. Hurwitz KM, Argyros GJ, Roach JM, Eliasson AH, Philips YY. Interpretation of eucapnic voluntary hyperventilation in the diagnosis of asthma. Chest 1995; 108: 1240-1245.

68. Schmekel B, Smith H-J. The diagnostic capacity of forced oscillation and forced expiration techniques in identifying asthma by isocapnic hyperpnoea of cold air. Eur Respir J 1997; 10: 2243-2249.

69. Djukanovic R, Homeyard S, Gratziou C, Madden J, Walls A, Montefort S, Peroni D, Polosa R, Holgate S, Howarth P. The effect of treatment with oral corticosteroids on asthma symptoms and airway inflammation. Am J Respir Crit Care Med 1997; 155: 826-832.

70. Djukanovic R, Wilson JW, Britten YM, Wilson SJ, Walls AF, Poche WF, Howarth PH, Holgate ST. Effect of an inhaled corticosteroid on airway inflammation and symptoms of asthma. Am Rev Respir Dis 1992; 145: 669-674.

71. Wilson JW, Djukanovic R, Howarth PH, Holgate ST. Lymphocyte activation in bronchoalveolar lavage and peripheral blood in atopic asthma. Am Rev Respir Dis 1992; 145: 958-960. 
72. Wang JH, Devalia JL, Sapsford RJ, Davies RJ. Effect of corticosteroids on release of RANTES and sICAM-1 from cultured human bronchial epithelial cells, induced by TNF $\alpha$. Eur Respir J 1997; 10: 834-840.

73. Cronstein BN, Kimmel SC, Levin RI, Martiniuk F, Weissmann G. A mechanism for the antiinflammatory effects of corticosteroids: the glucocorticoid receptor regulates leucocyte adhesion to endothelial cells and expression of endothelial-leucocyte adhesion molecule-1 and intercellular adhesion molecule-1. Proc Natl Acad Sci USA 1992; 89: 9991-9995.

74. Evans PM, O'Connor BJ, Fuller RW, Barnes PJ, Chung KF. Effect of inhaled corticosteroids on peripheral blood eosinophil counts and density profiles in asthma. J Allergy Clin Immunol 1993; 91: 643-650.

75. Wood $\sqcup$, Inman MD, Watson RM, Foley R, Denburg JA, O'Byrne PM. Changes in bone marrow inflammatory cell progenitors after inhaled allergen in asthmatic subjects. $A m \mathrm{~J}$ Respir Crit Care Med 1998; 157: 99-105.

76. Cluzel M, Damon M, Chanez P, Bousquet J, Crastes de Paulet C, Michel FB, Godard Ph. Enhanced alveolar cell luminol-dependent chemiluminescence in asthma. I Allergy Clin Immunol 1987; 80: 195-201

77. Vachier I, Chanez P, Doucen Le C, Damon, Descomps B, Godard P. Enhancement of reactive oxygen species formation in stable and unstable asthmatic patients. Eur Respir J 1994; 7; 1585-1592.

78. Rahman I, Morrison D, Donaldson K, MacNee W. Systemic oxidative stress in asthma, COPD and smokers. Am J Respir Crit Care Med 1996; 154: 1055-1060.

79. Sont JK, Van Krieken JHJM, Evertse CE, Hooijer R, Willems LNA, Sterk PJ. Relationship between the inflammatory infiltrate in bronchial biopsy specimens and clinical severity of asthma in patients treated with inhaled steroids. Thorax 1996; 51: 496-502.

80. Sont JK, Van Krieken JHJM, Willems LNA, Sterk PJ. Additional reduction in airway subepithelial layer can be obtained by a treatment strategy aimed at improving bronchial hyperresponsiveness (BHR)in asthma. Am J Respir Crit Care Med 1997; 155: A502.

81. Trigg CJ, Manolitsas ND, Wang J, Calderon MA, MCAulay A, Jordan SE, Herdman MJ, Jhalli N, Duddle JM, Hamilton SA, Devalia JL, Davies RJ. Placebo-controlled immunopathological study of four months of inhaled corticosteroids in asthma. Am J Respir Crit Care Med 1994; 150: $17-22$.

82. Redington AE, Howarth PH. Airway remodelling in asthma. Thorax 1997; 52: 310-312.

83. Jatakanon A, Lim S, Kharitonov SA, Chung KF, Barnes PJ. Correlation between exhaled nitric oxide, sputum eosinophils, and methacholine responsiveness in patients with mild asthma. Thorax 1998; 53: 91-95.

84. Horvath I, Donelly LE, Kiss A, Lim S, Irusen E, Kharitonov SA, Fan Chung K, Barnes PJ. Combined use of exhaled hydrogen peroxide and nitric oxide in monitoring asthma. Am J Respir Crit Care Med 1998; 157: A610.

85. Guo FH, De Raeve HR, Rice TW, Stuehr DJ, Thunissen FBJM, Erzurum SC. Continuous nitric oxide synthesis by inducible nitric oxide synthase in normal human airway epithelium in vivo. Proc Natl Acad Sci USA 1995; 92: 7809-7813. 


\section{CHAPTER 10}

\section{Samenvatting en discussie}

\subsection{SAMENVATTING}

Het eerste deel van dit proefschrift beschrijft het effect van TNF $\alpha$ op de ontwikkeling van bronchiale hyperreactiviteit in vitro en onderzoekt effecten van geneesmiddelen, gebruikt bij de behandeling van astma, op het immuun-systeem middels in vitro onderzoek.

Diverse studies hebben aangetoond dat TNF $\alpha$ een rol speelt in de pathofysiologie van astma. Cellen, betrokken bij de astmatische ontstekingsreactie, zoals epitheelcellen, mestcellen, geactiveerde T-lymfocyten en macrofagen, tonen een verhoogde afgifte van TNF $\alpha$ en TNF $\alpha$ versterkt op zijn beurt de inflammatoire reactie, leidend tot een ontstekings-spiraal.

$\mathrm{Na}$ blootstelling aan allergenen worden tijdens de late astmatische reactie (LAR) verhoogde concentraties van TNF $\alpha$ aangetroffen. Aangezien deze LAR gepaard gaat met een toename van bronchiale hyperreactiviteit, veronderstelden wij dat TNF $\alpha$ de contractiliteit van glad spierweefsel, gelokaliseerd in de bronchiën, door een direct effect zou kunnen doen toenemen. In hoofdstuk 3 onderzochten wij het effect van TNF $\alpha$ op de isotone contractie van tracheaal glad spierweefsel van de cavia, opgehangen in een orgaan-bad. Toevoeging van TNF $\alpha\left(10^{-13}\right.$ tot $\left.10^{-10} \mathrm{M}\right)$ gedurende 30 minuten aan dit orgaan-bad, resulteerde in een toename van de gestimuleerde maximale contractie van glad spierweefsel met $70 \%$. Gelijktijdige toevoeging van een specifiek TNF $\alpha$-blokkerende stof (sTNFR-p80) aan dit orgaan-bad deed de toegenomen contractiliteit volledig verdwijnen; dit bewijst dat het effect inderdaad specifiek door TNF $\alpha$ veroorzaakt wordt. Aanvullend blijkt dat een periode van meer dan 30 minuten vereist is alvorens het effect van TNF $\alpha$ op de contractiliteit van glad spierweefsel bemerkbaar wordt; dit zou erop kunnen duiden dat er andere mediatoren door TNF $\alpha$ geïnduceerd worden. Het is bekend dat TNF $\alpha$ het enzym fosfolipase $A_{2}$ stimuleert, hetgeen ondermeer leidt tot de vorming van prostaglandines en PAF. Om dit te onderzoeken voerden wij een experiment uit waarbij, gelijktijdig met $\mathrm{TNF} \alpha$, een specifieke prostaglandine-synthese remmer (indometacine) of WEB 2086 (een stof, welke PAF-effecten remt) werd toegevoegd aan het orgaan-bad. Alhoewel indometacine zelf ook de contractiliteit van het gladde spierweefsel bleek te verhogen, bleek er geen beïnvloeding van het TNF $\alpha$ effect aanwezig. Echter, toevoeging van WEB 2086 blokkeerde het effect van TNF $\alpha$ volledig, er op duidend dat PAF betrokken is in het effect van TNF $\alpha$ op glad spierweefsel. Gezien het tijdsbeloop in onze experimen- 
ten en de biologische beschikbaarheid van PAF, speculeren wij dat ofwel TNF $\alpha$ de aanmaak van PAF in gladde spier cellen stimuleert ofwel dat gladde spier cellen contact maken met cellen, die, ten gevolge van blootstelling aan TNF $\alpha$, PAF produceren en via de PAF-receptor van de gladde spiercel de contractiliteit van deze cel beïnvloeden.

De bevindingen in deze studie vullen observaties in humane studies aan en leiden tot de hypothese dat blootstelling aan TNF $\alpha$ resulteert in bronchiale hyperreactiviteit door een directe beïnvloeding van gladde spier contractiliteit door TNF $\alpha$.

Nadat dit effect van TNF $\alpha$ op de contractiliteit van gladde spieren aangetoond was, onderzochten wij in hoofdstuk 4 de effecten van theofylline op de uitscheiding van pro-inflammatoire mediatoren (TNF $\alpha$, IL-6 en IL-8) en oplosbare TNF-receptoren, zowel in monocyten als alveolaire macrofagen. Theofylline bleek een dosis-afhankelijke remming van de uitscheiding van TNF $\alpha$ in lipopolysaccharide(LPS)-gestimuleerde monocyten te veroorzaken; bij een theofylline-concentratie van $20 \mu \mathrm{g} / \mathrm{ml}$ was er sprake van een gedeeltelijke remming, welke maximaal was bij een concentratie van $80 \mu \mathrm{g} / \mathrm{ml}$; deze concentratie wordt echter klinisch niet gebruikt, omdat deze gepaard gaat met onacceptabele bijwerkingen. Aanvullend onderzoek laat zien dat op mRNA-niveau, theofylline $(20 \mu \mathrm{g} / \mathrm{ml})$ de ophoping van LPS-gestimuleerde TNF $\alpha$-mRNA met 59\% remt en de ophoping van LPS-geïnduceerde IL-6 mRNA met 49\% remt. Echter in het geval van IL-6, worden er op eiwit-niveau nauwelijks veranderingen gevonden, zodat wij vermoeden dat de verminderde IL-6 mRNA synthese gecompenseerd wordt door post-transcriptionele mechanismen.

Aanvullend bleek dat de door theofylline veroorzaakte remming van de uitscheiding van TNF $\alpha$ niet verklaard kan worden door verhoogde concentraties van IL-10 (IL-10 remt namelijk de synthese van TNF $\alpha$ ); integendeel, theofylline leek eerder een daling van IL-10 te veroorzaken. Dit zou kunnen berusten op een, door theofylline veroorzaakte, daling van TNF $\alpha$, aangezien TNF $\alpha$ de aanmaak van IL-10 induceert, als onderdeel van een natuurlijk regulatie-mechanisme.

In tegenstelling tot monocyten, bleek theofylline geen invloed te hebben op de uitscheiding van cytokines door macrofagen, hetgeen verklaard zou kunnen worden door het feit dat macrofagen verder uitgerijpt zijn dan monocyten. Dit laatste verklaart waarschijnlijk ook de bevinding dat macrofagen meer TNF $\alpha$ uitscheiden dan monocyten. Zo bleek theofylline ook de afsplitsing van TNF-receptor-75 te beïnvloeden in monocyten, terwijl er geen veranderingen optraden in macrofagen. Het belang van dit verschil is vooralsnog onduidelijk.

In menselijke bloedvatcellen (endotheel) bleek theofylline $(100 \mu \mathrm{g} / \mathrm{ml})$ de expressie van VCAM-1 op de membraan van TNF $\alpha$-gestimuleerde endotheel-cellen te remmen, terwijl er geen effect gezien werd op de LPS-gestimuleerde VCAM-1 expressie van endotheel-cellen. De expressie van andere adhesie-moleculen 
(ICAM-1 en E-selectin-1) of uitscheiding van proinflammatoire mediatoren (IL-6 en IL-8) werd niet beinvloed door theofylline. Aangezien VCAM-1 betrokken is in de regulatie van de influx van eosinofielen en lymfocyten in weefsel, zouden bevindingen uit ons in vitro onderzoek de basis kunnen vormen voor bevindingen in humaan onderzoek, die laten zien dat theofylline ophoping van eosinofielen en T-lymfocyten in bronchusweefsel remt en dat staken van theofylline leidt tot een toename van deze cellen in de bronchiaal mucosa van patiënten met astma.

Samenvattend laat het onderzoek, beschreven in dit hoofdstuk, zien dat theofylline in vitro immuno-modulerende eigenschappen bezit, op basis waarvan een deel van de gunstige effecten van theofylline in de behandeling van astma verklaard zouden kunnen worden.

Naast theofylline wordt tegenwoordig bij de behandeling van astma in toenemende mate gebruik gemaakt van zogenaamde langwerkende $\beta_{2}$-sympaticomimetica. De toegevoegde waarde van deze medicatie voor de behandeling van astma zou, naast luchtweg-verwijding, ook kunnen berusten op immuno-modulerende effecten. In hoofdstuk 5 werden de effecten van salmeterol en salbutamol op de uitscheiding van pro-inflammatoire mediatoren (TNF $\alpha$, IL-6 en IL-8) onderzocht in vitro in LPS-gestimuleerde monocyten, afkomstig van bloed van gezonde vrijwilligers. Salmeterol $\left(10^{-8}-10^{-6} \mathrm{M}\right)$ en salbutamol $\left(10^{-8}-10^{-4} \mathrm{M}\right)$ bleken beide de uitscheiding van TNF $\alpha$ te remmen (maximale remming 50\%) en voor IL-6 werd er een trend tot remming gezien. $\mathrm{Bij}$ salbutamol bleek er sprake van een dosis-afhankelijke remming van TNF $\alpha$, terwijl er voor salmeterol al een maximale remming van TNF $\alpha$ optrad bij de laagste concentraties. Coïncubatie met propranolol, een $\beta$-antagonist, bleek het effect van salmeterol en salbutamol volledig teniet te doen, aantonend dat de $\beta$-receptor betrokken is in dit effect. Aanvullend bleek dat IL-10 hier mogelijk wel betrokken is in de remming van TNF $\alpha$ door salmeterol en salbutamol, aangezien in deze experimenten de IL-10 uitscheiding wel bleek toe te nemen bij de hoogste concentratie van LPS. Aangezien de uitscheiding van TNF $\alpha$ ook geremd werd in experimenten waar geen verhoogde uitscheiding van IL-10 aanwezig was, werden de effecten van salmeterol en salbutamol op de LPS-geïnduceerde ophoping van TNF $\alpha$ - en IL-6 mRNA onderzocht, analoog aan de experimenten met theofylline. Zowel salmeterol als salbutamol bleken de ophoping van $\mathrm{TNF} \alpha \mathrm{mRNA}$ en in mindere mate IL-6 mRNA te remmen.

Het tweede deel van het proefschrift beschrijft de effecten van behandeling met inhalatie-steroïden (beclomethasone dipropionate) in patiënten met stabiel, mild astma bronchiale. Gekeken werd naar de effecten op astma-symptomen en bronchiale hyperreactiviteit, gemeten met behulp van koude lucht bronchoprovocatie. Tegelijkertijd werd het effect van de behandeling met inhalatie-steroïden vervolgd aan de hand van biologische merkstoffen in het bloed van astmatische patiënten. 
In hoofdstuk 6 wordt het effect van de behandeling met geïnhaleerd beclomethasone dipropionate $(1000 \mu \mathrm{g} / \mathrm{dag}$ gedurende zes weken) vervolgd aan de hand van astma-symptomen, piek-flow en long-functie-metingen alsmede bepalingen van de bronchiale hyperreactiviteit. Veertig patiënten met stabiel, mild astma (geen inhalatie-sterö̈den gebruikend) namen deel aan een dubbel-blind, placebo-gecontroleerd onderzoek. Per groep namen evenveel mannen als vrouwen deel om te corrigeren voor verschillen in luchtwegdiameter. Bronchiale hyperreactiviteit werd bepaald middels de isocapnische koude lucht bronchoprovocatie techniek, welke op een natuurlijke wijze een luchtweg-vernauwing induceert en een betrouwbare maatstaf voor bronchiale hyperreactiviteit vormt. Het effect van koude lucht inhalatie werd beoordeeld aan de hand van flow-volume metingen alsmede middels impedantie-metingen van de luchtwegen met behulp van de geforceerde oscillatie techniek (FOT). FOT metingen behoeven niet vooraf gegaan te worden door geforceerde inademingsmanoeuvres, die, doordat zij luchtweg verwijding kunnen geven, het resultaat van de hyperreactiviteits-metingen kunnen beïnvloeden. Koude lucht bronchoprovocatie resulteerde bij onze patiënten in duidelijke dalingen van de $\mathrm{FEV}_{1}$ (18\% van de uitgangswaarde) en karakteristieke veranderingen in de impedantie-curves: een toename van de weerstand bij $8 \mathrm{~Hz}$, de ontwikkeling van een negatieve frequentie-afhankelijkheid van de weerstands-curve (dwz. de weerstand daalt bij stijgende frequentie van het opgelegde signaal), een daling van de reactantie bij $8 \mathrm{~Hz}$ en een stijging van de resonantie-frequentie (dwz. die frequentie, waarbij de reactantie-curve de nullijn passeert). Observaties in ons onderzoek bevestigden bevindingen uit eerdere studies. Verder bleken de veranderingen in de FOT parameters te correleren met de veranderingen in de $\mathrm{FEV}_{1}$. Behandeling van patiënten met beclomethasone resulteerde in een afname van de reactie op de koude lucht bronchoprovocatie, geëvalueerd middels de geforceerde oscillatie techniek. Belangrijkste bevindingen waren een minder sterke weerstandstijging bij $8 \mathrm{~Hz}$, een minder uitgesproken negatieve frequentie-afhankelijkheid, een minder sterke daling van de reactantie bij $8 \mathrm{~Hz}$ alsmede een minder sterke stijging van de resonantie-frequentie. Alhoewel in het conventionele longfunctie onderzoek een tendens tot minder sterke daling van de $F E V_{1}$ na koude lucht inhalatie aanwezig leek te zijn, waren deze veranderingen niet significant verschillend van de placebo-groep. Verder bleek het IgE gehalte in bloed te correleren met het effect van beclomethasone op de koude lucht broncho-provocatie. Astma-symptoom scores, piek-flow metingen alsmede medicatie gebruik veranderden niet in de met beclomethasone-behandelde groep; bedacht moet wel worden dat deze patiënten al een stabiel, licht astma hadden met relatief weinig klachten.

Samenvattend tonen wij in dit hoofdstuk aan dat behandeling met beclomethasone bronchiale hyperreactiviteit vermindert in patiënten met stabiel astma en dat de 
geforceerde oscillatie techniek gevoeliger is voor veranderingen in de tonus van de luchtwegen dan de conventionele flow-volume bepalingen.

Hoofdstuk 7 beschrijft de veranderingen van inflammatoire mediatoren in het bloed van patiënten, welke deelnamen aan het protocol, zoals beschreven in hoofdstuk 5 . Wij bestuurden veranderingen in het niveau van circulerende adhesie-moleculen, enerzijds omdat deze moleculen in toegenomen hoeveelheid aanwezig zijn in de bronchiaal mucosa van astmatici, andererzijds omdat, zowel bij acuut astma als na allergeen provocatie, in het perifeer bloed verhoogde concentraties van circulerende adhesie-moleculen waargenomen zijn. Dit suggereert dat veranderingen van mediatoren in perifeer bloed in bepaalde mate veranderingen in het long compartiment kunnen weerspiegelen. Aangezien TNF $\alpha$ de expressie van adhesiemoleculen, zowel op epitheel - als endotheel-cellen doet toenemen, onderzochten wij ook de hoeveelheid circulerende TNF-receptoren, welke een goede maat vormen voor de inflammatoire status van een patient. Ook voor circulerende TNF-receptoren geldt dat zij bij een exacerbatie van astma in verhoogde concentraties kunnen voorkomen in perifeer bloed. Bij aanvang van de studie bleken het niveau van circulerende inflammatoire mediatoren (sICAM-1, sE-selectin-1, sTNF-R55 en sTNF-R75) in onze groep van astma-patiënten vergelijkbaar met het niveau van deze mediatoren in bloed van gezonde vrijwilligers. Behandeling met beclomethasone resulteerde in een significante afname van circulerend TNF-R55 in astmatische patiënten, welke reeds bemerkbaar was na 2 weken behandeling. Daarnaast trad er een geleidelijke daling op in het niveau van circulerend ICAM-1, welke na 6 weken statistisch significant was. Opvallend was dat de grootte van verandering in sICAM-1 $(30 \mathrm{ng} / \mathrm{ml})$ vergelijkbaar was met veranderingen van sICAM-1 in perifeer bloed na segmentele allergeen provocatie. Verder bleek behandeling met beclomethasone vanaf 2 weken te resulteren in een significante daling van het aantal eosinofiele cellen in perifeer bloed. Alhoewel veranderingen in circulerend ICAM-1 en TNF-R55 significant correleerden met niveaus ten tijde van het begin van de studie, bleken de veranderingen ten tijde van behandeling met beclomethasone niet te correleren met de ernst van astma, gemeten aan long-functie, bronchiale hyperreactiviteit en aantal eosinofiele granulocyten. Wij veronderstellen dat de veranderingen van sTNF-R55 en sICAM-1 in perifeer bloed een weerspiegeling zijn van de anti-inflammatoire effecten van beclomethasone op de bronchiale mucosa.

Vervolgens beschrijven wij in hoofdstuk 8 de niveaus van antioxidatieve enzymen (superoxide dismutase, catalase, glutathion-peroxidase en glutathion S-transferase) en anti-oxidanten (glutathion) in de erythrocyten van de hierboven beschreven groep patiënten en vervolgen het effect van behandeling met beclomethasone op het anti-oxidatief systeem. 
Cellen, betrokken bij de astmatische reactie, produceren toegenomen hoeveelheden zuurstof radicalen. Deze zuurstof radicalen spelen een rol in de pathofysiologie van astma, aangezien zij veranderingen in luchtweg-reactiviteit, lekkage van plasma en productie van inflammatoire mediatoren veroorzaken (bijvoorbeeld PAF). Daarnaast blijkt er bij patiënten met astma ook nog sprake van een verlaging van hun anti-oxidatieve enzym-systeem (zoals ondermeer voor catalase en glutathion-peroxidase). Dit complex van veranderingen leidt er toe dat patiënten met astma een verstoorde oxidant-antioxidant balans hebben. In ons onderzoek hebben wij met name gekeken naar veranderingen in het antioxidatieve systeem van de erythrocyt, aangezien diverse studies hebben laten zien dat dit een goede weerspiegeling vormt voor de mate van chronische blootstelling aan zuurstof-radicalen.

Ons onderzoek laat zien dat tijdens behandeling met beclomethasone een geleidelijke toename van catalase optreedt, welke na 6 weken therapie significant verschilt ten opzichte van placebo. Glutathion verandert ook significant na 6 weken behandeling met beclomethasone, echter hier treedt een geleidelijke daling in het glutathion-gehalte van de erythrocyt op. De veranderingen in catalase bleken omgekeerd evenredig te zijn met het begin-niveau van catalase in de erythrocyt; dit was niet het geval voor glutathion. Verder bleken degenen, die tijdens behandeling met beclomethasone een stijging van het catalase lieten zien (responders), significant hogere aantallen eosinofiele granulocyten in het perifeer bloed te hebben ten opzichte van de non-responders. In dit onderzoek konden er geen verbanden gevonden worden tussen antioxidant niveaus en en de ernst van astma (longfunctie, bronchiale hyperreactiviteit, $\mathrm{IgE}$ ); evenzo bestond er geen correlatie tussen de effecten van beclomethasone op het antioxidatieve systeem en de ernst van de astma. Een mogelijke verklaring voor de door ons gevonden veranderingen in de antioxidant niveaus binnen de erythrocyt zou een verminderde blootstelling van erythrocyten aan zuurstof radicalen kunnen zijn, secundair optredend aan de anti-inflammatoire effecten van beclomethasone in de luchtwegen van astmatische patiënten.

\subsection{DISCUSSIE}

In dit proefschrift werd aangetoond dat TNF $\alpha$ bronchiale hyperreactiviteit opwekt ten gevolge van een direct effect van $\mathrm{TNF} \alpha$ op de contractiliteit van gladde spiercellen; ook andere cytokines, zoals IL-5 en IL-4, kunnen bronchiale hyperreactiviteit veroorzaken, echter tot op heden is er nog geen direct effect op gladde spier cellen aangetoond voor deze cytokines. TNF $\alpha$ wordt vroeg tijdens de inflammatoire reactie geproduceerd en kan op zijn beurt deze reactie versterken door toegenomen expressie van adhesiemoleculen en bevordering van cytokine 
uitscheiding door cellen. Derhalve wordt aan TNF $\alpha$ een centrale rol toebedeeld in de astmatische inflammatoire reactie. $\mathrm{W}_{\mathrm{ij}}$ onderzochten in vitro mogelijke anti-inflammatoire effecten van medicijnen, gebruikt in de behandeling van astma. Salmeterol en salbutamol remden de LPS-gestimuleerde ophoping van mRNA voor TNF $\alpha$ en IL-6 in vergelijkbare mate ten opzichte van theofylline, echter, terwijl de effecten van salmeterol en salbutamol al optraden bij therapeutische concentraties, bleken de effecten van theofylline pas op te treden bij relatief hoge doseringen. Een bezwaar van onze methode is dat voor ons onderzoek cellen afkomstig van gezonde vrijwilligers gebruikt werden, waarbij de activatie-toestand van deze cellen kan verschillen met die van astmatische patiënten. Voor theofylline is aangetoond dat de remming van fosfodiesterase meer uitgesproken is in atopische patiënten dan gezonden, leidend tot de veronderstelling dat theofylline bij astmatische patiënten al in lagere doseringen werkzaam kan zijn. Klinische studies lijken in deze richting te wijzen en momenteel worden er specifieke fosfodiesterase-IV remmers ontwikkelt, welke in vitro een meer uitgesproken anti-inflammatoire werking lijken te hebben dan theofylline.

Alhoewel wij in onze studies anti-inflammatoire effecten aantoonden voor $\beta_{2}$-agonisten in pharmaceutische concentraties, lijken er in vivo verschillen te zijn betreffende het anti-inflammatoir effect van lang-werkende $\beta_{2}$-agonisten ten tijde van acute astmatische reacties (zoals bijvoorbeeld optredend na allergeen-blootstelling) en in de meer chronische situatie. $\mathrm{Na}$ allergeen blootstelling remt salmeterol de ontwikkeling van bronchiale hyperreactiviteit, hetgeen deels verklaard zou kunnen worden door remmende effecten van salmeterol op TNF $\alpha$ (zoals beschreven in hoofdstuk 3 en 5). De discrepantie tussen onze bevindingen van anti-inflammatoire effecten van salmeterol (en salbutamol) in vitro en de schijnbaar afwezige invloed van salmeterol op de bronchiale inflammatie in stabiel astma zijn niet eenvoudig te verklaren. Zeker voor salmeterol zou men ook in vivo effect verwachten, mede gezien de lange werkingsduur van salmeterol. Een mogelijke verklaring hiervoor zou een verminderde productie van cAMP kunnen zijn ten gevolge van de astmatische inflammatie; alveolaire macrofagen van astmatische patiënten produceren inderdaad minder cAMP na stimulatie dan macrofagen, afkomstig van gezonde vrijwilligers. Het bronchusverwijdend effect van $\beta$-agonisten wordt hierdoor niet beïnvloed, aangezien dit niet via cAMP gemedieërd wordt. Daarentegen speelt cAMP wel een rol bij immuun-regulerende effecten van $\beta$-agonisten, zoals salmeterol. Dit zou verklaren waarom de anti-inflammatoire effecten van $\beta$-agonisten minder uitgesproken zijn bij de astmatische patiënt. Combinatie van lang-werkende $\beta_{2}$-agonisten met (inhalatie) corticosteroïden zou daarentegen kunnen leiden tot een versterkt anti-inflammatoir effect van de $\beta_{2}$-agonisten, leidend tot een effectievere behandeling van astma. 
Het tweede deel van het proefschrift beschrijft de effecten van geïnhaleerd beclomethasone op bronchiale hyperreactiviteit en op biologische merkstoffen in het perifere bloed van patiënten met astma.

Dit deel van het onderzoek werd verricht in patiënten met stabiel, licht astma. Volgens de nieuwe richtlijnen voor de classificatie van astma zouden deze patiënten omschreven moeten worden als patiënten met intermitterend astma. Onderzoek heeft aangetoond dat zelfs intermitterend astma gepaard gaat met bronchiale inflammatie en dat, zelfs bij deze patiënten, er al een verbreding van de basaal membraan aanwezig is.

De patiënten in onze onderzoeks-groep bezaten een uitgesproken bronchiale hyperreactiviteit, blijkend uit de omvang van hun reactie op de koude lucht bronchoprovocatie. Behandeling met beclomethasone verminderde de bronchiale hyperreactiviteit, mits gemeten met behulp van de geforceerde oscillatie techniek.

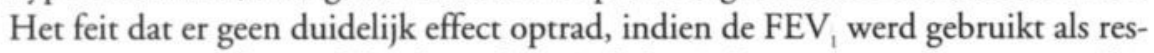
pons-parameter kan verklaard worden uit de bevindingen van een recente studie, die liet zien dat, juist in patiënten met lichte vormen van astma, de geforceerde diepe inspiratie, zoals vereist voor de $\mathrm{FEV}$, bepaling, leidt tot een uitgesproken luchtweg-verwijding en derhalve de door koude lucht opgewekte luchtweg-vernauwing maskeert.

We veronderstellen dat ook in onze patiënten-groep een bronchiale inflammatie aanwezig moet zijn, volgend uit het feit dat bronchiale hyperreactiviteit en luchtweg inflammatie aan elkaar gecorreleerd zijn. Alhoewel wij bij onze patiënten geen bronchusbiopten genomen hebben, bleek beclomethasone in een andere studie, met een vergelijkbare studie-duur en intensiteit van behandeling, een significante reductie van bronchiale inflammatie te bewerkstelligen. Ook bleek beclomethasone een verandering in de activatie status van T-lymfocyten te veroorzaken, zowel in de broncho-alveolaire lavage als in perifeer bloed. Derhalve vervolgden wij veranderingen in merkstoffen in perifeer bloed, die de veranderingen van bronchiale inflammatie zouden kunnen weerspiegelen, zoals beschreven in de laatste twee hoofdstukken van dit proefschrift. Aangezien pilot-studies geen pro-inflammatoire cytokines (TNF $\alpha$, IL-6 en IL-8) konden aantonen in het perifere bloed van onze patiënten, gebruikten wij andere markers van inflammatie in het perifere bloed. Wij vonden dat ten tijde van behandeling met beclomethasone een daling van circulerend TNF-R55 en ICAM-1 optrad, parallel met een daling van de bronchiale hyperreactiviteit. Mogelijke verklaringen voor deze daling van inflammatoire mediatoren zou kunnen zijn dat beclomethasone de aanmaak van deze stoffen in epitheel- of endotheel-cellen remt of dat beclomethasone de produktie van cytokines zoals IL- 4 en TNF $\alpha$ remt, die de expressie van deze mediatoren mede beïnvloeden.

Het effect van beclomethasone op het aantal eosinofiele granulocyten in de circulatie onderschrijft bevindingen uit andere studies. Men denkt dat cellen, gelokali- 
seerd in de long, kolonie-stimulerende factoren produceren, die de hematologische stamcellen aanzetten tot productie van ondermeer eosinofiele granulocyten. Corticosteroïden zouden dan effect kunnen uitoefenen op het aantal perifere eosinofiele granulocyten ofwel door een remmende werking op de synthese van deze kolonie-stimulerende factoren of door remming van het vrijkomen van eosinofiele granulocyten vanuit het beenmerg naar de bloedbaan. Wij vermoeden dat de door ons waargenomen vermindering van het aantal eosinofiele cellen zou kunnen berusten op een remming van de bronchiale inflammatie met daarop volgend een afname van de productie van kolonie-vormende factoren.

Analoog hieraan zouden de veranderingen in de antioxidanten en antioxidatieve enzymen, zoals die optraden in erythrocyten, verklaard kunnen worden door een afname van de productie van zuurstof-radicalen, eveneens veroorzaakt door remming van de astmatische inflammatie door beclomethasone. De progenitor cellen in het beenmerg zouden dan hierop kunnen reageren met een verminderde aanmaak van anti-oxidatieve enzymen. Aangezien astma niet alleen gepaard gaat met verhoogde zuurstof-radicaal productie, maar ook met verlaging van antioxidatieve enzymen, is het vanuit therapeutisch oogpunt van belang op welke (primaire) stoornis wij onze behandeling moeten richten. Om dit adequaat te kunnen onderzoeken is gelijktijdige bestudering van zowel de zuurstof radicaal productie als analyse van de anti-oxidatieve verdedigingsmechanismen van belang.

Beclomethasone bleek in staat een afname van bronchiale hyperreactiviteit en een daling van inflammatoire mediatoren te induceren in patiënten met ogenschijnlijk stabiel, licht astma. Afgaand op de symptomen van astma in onze patiënten, zou er volgens de vigerende internationale richtlijnen geen reden geweest zijn hen te behandelen met corticosteroïden. Er blijkt echter een duidelijke discrepantie te kunnen optreden tussen astma-symptomen en mate van bronchiale inflammatie. Aangezien er een redelijke correlatie bestaat tussen bronchiale hyperreactiviteit en bronchiale inflammatie, zou dit een reden kunnen zijn om, behoudens astmasymptomen, ook de ernst van bronchiale hyperreactiviteit mee te wegen in onze overwegingen betreffende de medicamenteuze behandeling van astma. Sont en co-auteurs toonden aan dat deze manier van behandeling leidt tot een betere controle van astma en de structurele omvorming van astmatische luchtwegen remt. Er zijn aanwijzingen dat vroegtijdige introductie van inhalatie-corticosteroïden kan leiden tot een vermindering van de al aanwezige structurele ombouw van de astmatische luchtwegen, waarvan men aanneemt dat deze plaats vindt onder invloed van inflammatoire mediatoren (bijvoorbeeld IL-4, TNF $\alpha$ ). Derhalve lijken technieken, welke bronchiale inflammatie vroegtijdig kunnen detecteren, van belang in de klinische praktijk om deze chronische structurele ombouw van astmatische luchtwegen te voorkomen. 
Uit dit proefschrift blijkt dat de mediatoren, die wij gebruikt hebben in onze studies om astma te monitoren, niet geschikt zijn als "biomarkers": niveaus van circulerend ICAM-1 en TNF-R55 bleken enerzijds niet te discrimineren tussen patiënten met astma en gezonde personen, anderzijds bleek er onvoldoende samenhang tussen de concentraties van deze stoffen en de ernst van astma. Evenmin bleken zij te het effect van beclomethasone op de bronchiale hyperreactiviteit te kunnen voorspellen. De verklaring hiervoor zou kunnen zijn dat astma zich primair gedraagt als een ontsteking, met name gelokaliseerd in het long-compartiment, en, alhoewel er soms lekkage van deze mediatoren naar de algemene circulatie kan optreden, weerspiegelt dit onvoldoende de (bronchiale) astmatische inflammatie. Combinatie van onze "markers" met nieuwere onderzoeks-methoden (zoals bijvoorbeeld geïnduceerd sputum of bepaling van vluchtige gassen in uitademings-lucht (bijv.NO)), zou een oplossing kunnen bieden. Recent bleek dat de combinatie van het aantal eosinofiele granulocyten in geïnduceerd sputum en meting van $\mathrm{NO}$ in uitgeademde lucht bij patiënten met astma wel meer informatie biedt over de uitgebreidheid van de inflammatie, echter desalniettemin bleef de samenhang met astma symptomen laag. Van belang is verder dat bepaalde medicijnen, gebruikt ter behandeling van astma, ook rechtstreeks de productie van deze markers beinvloedt en daarmee de markers als monitor van de ziekte-activiteit onbetrouwbaar maakt. Of markers in perifeer bloed (zoals ondermeer ECP, adhesie-moleculen, T-lymfocytaire activatie markers), gecombineerd met nieuwere technieken een toegevoegde waarde zullen hebben in de karakterisering en monitoring van de bronchiale inflammatie in de individuele patiënt met astma zal nader onderzocht moeten worden. 


\title{
APPENDICES
}

\author{
Dankwoord \\ List of Publications \\ Curriculum Vitae
}





\section{Dankwoord}

Een proefschrift wordt zelden alléén gemaakt en vormt dan ook de afsluiting van een (soms langer dan geplande) periode, waarin er met veel mensen meer of minder intensief is samen gewerkt. Dit is dan ook bij uitstek de plaats om al die personen te bedanken, die betrokken waren bij de totstandkoming van dit proefschrift.

Prof. Dr. E.F.M. Wouters, beste Emiel, onze allereerste kennismaking begon met de vraag of ik toch echt niet eerst onderzoek wilde doen, alvorens aan de opleiding Longziekten te beginnen. Ondanks mijn ontkennende antwoord, heeft het volgens mij nog geen jaar geduurd alvorens je mij met het eerste onderzoeksvoorstel confronteerde. Alhoewel het onderwerp zich in een voor mij volstrekt onbekend onderzoeksveld bevond, ben je er toch in geslaagd mij enthousiast te krijgen voor onderzoek, zoals beschreven in dit proefschrift. Gaarne wil ik je bedanken voor de energie en moeite die je hebt gestoken in de correctie van de manuscripten en de toelichtingen op de materie. Met name je vermogen de materie in een breder perspectief te plaatsen en te relateren aan andere onderzoeksresultaten leverde een duidelijk verdieping van de discussie op, waarvoor ik je zeer erkentelijk ben. Ik hoop dat wij de onderzoeksrelatie nog vele jaren kunnen continueren.

Dr. W.A. Buurman, beste Wim, zeker in het begin zal ik voor jou een vreemde (pulmonologische) eend in de (heelkundige) bijt geweest zijn. Jouw overtuiging dat een promovendus zelf de bepalingen verricht moet hebben om te weten waarover hij/zij praat, kan ik van harte ondersteunen, alhoewel ik wel denk dat verdere automatisering op het lab ook zijn prettige kanten heeft. Ik dank je voor onze besprekingen en de kritische beoordeling van de manuscripten, waarbij je vlot mijn (soms al te lange betogen) minimaliseerde tot essentiële punten, waardoor de kwaliteit van het manuscript met stukken vooruit ging. Je brede belangstelling en kennis waren een belangrijke steun in de totstandkoming van dit proefschrift.

Hierbij wil ik ook de leden van de beoordelingscommissie bedanken voor hun bereidheid deze thesis te willen beoordelen. Een speciaal woord van dank geldt voor Prof. Dr. A. Bast, zowel voor het bekleden van het voorzitterschap van de beoordelingscommissie, als ook voor de betoonde gastvrijheid op het laboratorium aan de $\mathrm{VU}$, alwaar een deel van het onderzoek in dit proefschrift verricht is.

Uiteraard was mijn start op het laboratorium algemene heelkunde (toen nog in het $\mathrm{BMC}$ ) niet zo prettig verlopen zonder de hulp van al die mensen die daar werk- 
zaam waren: Ingeborg, Mark, Maarten, Albert, Jeske, Jessica, Monique, Sandra, Ivo, Trudy, Gaby en Mieke. Mieke, jij was degene die mij de fijne kneepjes van het lab-werk heeft bijgebracht en altijd behulpzaam was bij problemen, ook indien ik 's nachts op het BMC weer eens iets niet kon vinden. Gaandeweg is jouw belangstelling ook meer richting Pulmonologie verplaatst en hebben wij nog een aantal studies verricht buiten het kader van dit proefschrift. Dank voor je hulp.

Verder moet ik al mijn ex-collega-assistenten (Marcel, Jean, Harrie, Ellen en Frank), de collega's in het AZM (Guul, Geertjan, Arne en Marjolein) en mijn huidige collega's (Rob, Jean (alweer) en Joan) bedanken voor hun bereidheid bepaalde taken over te nemen, zeker als er weer eens een dag labwerk verricht moest worden en mijn pieper een goed onderkomen zocht. Zonder jullie hulp was dit alles niet gelukt.

Uiteraard hartelijk dank aan het secretariaat Longziekten AZM (Anouk, France, Gonda, Manon, Nicole en Resy) en ons secretariaat Hornerheide (Annemiek en Gerrie) voor de geboden ondersteuning.

Ik ben mijn vader en moeder dankbaar dat zij het mij mogelijk gemaakt hebben te gaan studeren en mij het uithoudingsvermogen hebben meegegeven, dat nodig is voor het afronden van een proefschrift. Het is alleen jammer dat mijn grootvader en peetoom $\mathrm{H}$. Follmer de voltooiing van mijn proefschrift niet meer heeft mogen meemaken.

Beste Justine, aan alles komt een eind: dit geldt voor het dankwoord, maar gelukkig ook voor de promotie-periode. Ik dank je voor je geduld en ik hoop dat wij weer meer tijd aan elkaar en aan de kinderen kunnen besteden. 


\section{List of Publications}

\section{FULL PAPERS}

Presence of Bactericidal/Permeability-increasing protein in disease: Detection by ELISA. M.A. Dentener, G.J.M. Francot, F.T. Smit, H.J. Pennings, W.A. Buurman, E.F.M.Wouters.

J Infect Dis 1995; 171: 739-843.

Diagnostic value of lactate dehydrogenase isoenzyme pattern in pleural effusions. N.A.M. Cobben, A.F. van Belle, H.J. Pennings, P.G.H. Mulder, M.P. van Dieijen-Visser, E.F.M. Wouters, M. Drent.

Eur J Chem Clin Biochem 1997; 35: 523-528.

Effect of inhaled Beclomethasone dipropionate on isocapnic hyperventilation with cold air in asthmatics, measured with forced oscillation technique. H.J. Pennings, E.F.M. Wouters.

Eur Respir J 1997; 10: 665-671.

Tumor Necrosis factor-alpha induces hyperreactivity in tracheal smooth muscle of the guinea pig in vitro. Evidence for the involvement of Platelet-activating factor. H.J. Pennings, K. Kramer, A. Bast, W.A. Buurman, E.F.M. Wouters.

Eur Respir J 1998; 12: 45-49.

Evaluation of immunomodulatory properties of theophylline; an in vitro study in human cells. H.J. Pennings, M.A. Dentener, S. Verploegen, S.H. Korn, F.B.J.M. Thunnissen, W.A. Buurman, E.F.M. Wouters.

(submitted)

Salmeterol and salbutamol decrease TNF $\alpha$ release in human monocytes. H.J. Pennings, M.A. Dentener, S.H. Korn, F.B.J.M. Thunissen, W.A. Buurman, E.F.M. Wouters.

(submitted)

Beclomethasone dipropionate attenuates levels of soluble TNF-Receptor-55 and circulating ICAM-1 in patients with stable asthma. H.J. Pennings, M.A. Dentener, W.A. Buurman, E.F.M. Wouters.

(submitted) 
Changes in levels of catalase and glutathione in erythrocytes of patients with stable asthma, treated with beclomethasone dipropionate. H.J. Pennings, P.J.A. Borm, C.T.A. Evelo, E.F.M. Wouters.

(submitted)

The DD genotype of the angiotensin converting enzyme gene is negatively associated with right ventricular hypertrophy in patients with chronic obstructive pulmonary disease. R.J. van Suylen, E.F.M. Wouters, H.J. Pennings, E.C. Cheriex, P.E. Van Pol, A.W. Ambergen, A-M. Vermelis, M.J. Daemen.

(submitted) 


\section{Curriculum Vitae}

The author of this thesis was born on April 3rd, 1959 in Berlicum, The Netherlands. He attended high school (Gymnasium $\beta$ ) at the "Sint Jans lyceum" in 's Hertogenbosch from 1971 until 1977. In 1977, he started his training in medicine at the University of Nijmegen and obtained his medical degree in 1985.

He worked for three months as "AGNIO" at the Sint Laurentius Hospital in Roermond, and subsequently started his training as a resident at the Department of Internal Medicine, Groot Ziekengasthuis 's Hertogenbosch (Head: Dr. J.L.J. Jansen), where he worked until May 1989. In May 1989, he switched residency and worked as a resident at the Department of Pulmonology, University Hospital Maastricht (Head: Prof. Dr. E.F.M. Wouters) from 1989 till December 1993. On January 1st 1994, he was registered as a pulmonologist and he worked, until December 1997, as a staff member at the Department of Pulmonology, University Hospital Maastricht. Starting from January 1997, he is a member of the pulmonology staff at the Pulmonary Rehabilitation Center Hornerheide, Horn, the Netherlands. 

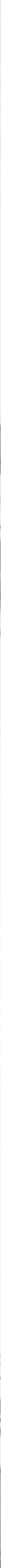